\title{
Assessment of Salmonid Fishes and Their Habitat Conditions in the Walla Walla River Basin
}

\section{目}

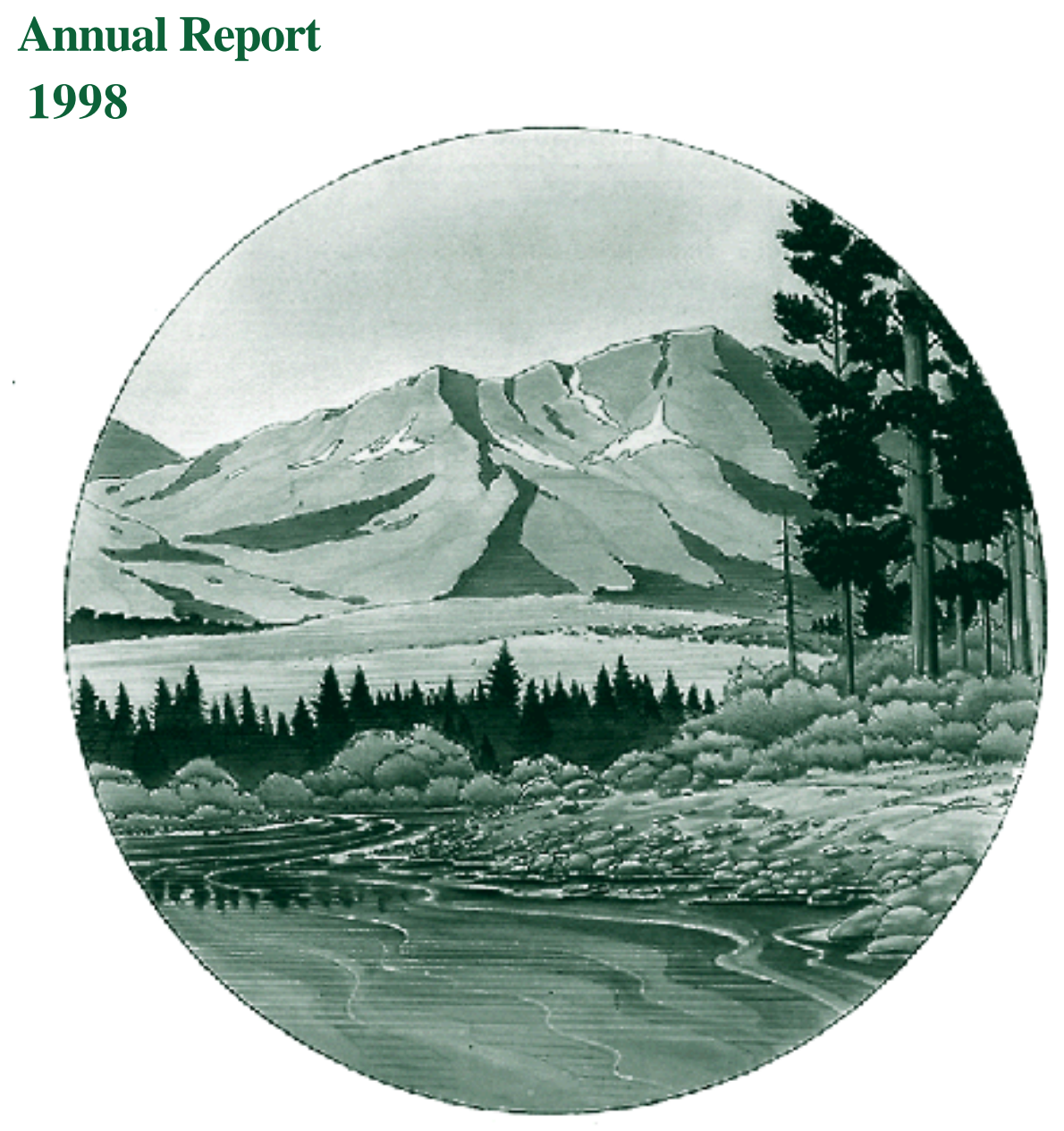

DOE/BP-07035-1

August 1999 
This Document should be cited as follows:

Mendel, Glen, David Karl, Virginia Naef, "Assessment of Salmonid Fishes and Their

Habitat Conditions in the Walla Walla River Basin", Project No. 1998-02000, 105

electronic pages, (BPA Report DOE/BP-07035-1)

\author{
Bonneville Power Administration \\ P.O. Box 3621 \\ Portland, Oregon 97208
}

This report was funded by the Bonneville Power Administration (BPA), U.S. Department of Energy, as part of BPA's program to protect, mitigate, and enhance fish and wildlife affected by the development and operation of hydroelectric facilities on the Columbia River and its tributaries. The views in this report are the author's and do not necessarily represent the views of BPA. 


\title{
Assessment of Salmonid Fishes and Their Habitat Conditions in the Walla Walla River Basin:
}

\section{Annual Report}

\author{
By: \\ Glen Mendel, Virginia Naef and David Karl \\ Washington Department of Fish and Wildlife \\ Fish Program \\ 529 W. Main St. Dayton, WA 99328
}

\section{For}

U.S. Department of Energy

Bonneville Power Administration

Environment, Fish and Wildlife

P.O. Box 3621

Portland, OR 97208

Project Number 98-20

Contract Number 98BI07035

\section{August 1999}




\section{Acknowledgments}

Many people and organizations contributed to this project. First we would like to thank the Bonneville Power Administration for funding this project, and Charlie Craig (BPA) for his patience and assistance.

This project could not have progressed without the approval of landowners in granting access to their lands. We sincerely appreciate their cooperation.

We appreciate the assistance from the WDFW Snake River Lab. They shared equipment and provided some data on the Touchet River, as well as assisted with some electrofishing sites. Other WDFW personnel also provided valuable assistance. Jon Kunz was always eager and he was invaluable in data collection and data entry. Justin Steinhof and John Skidmore also assisted in data collection.

Bill Neve and John Covert (DOE) provided valuable assistance with establishing and operating the constant recording stream flow monitoring sites. Mike Northrup and Larry Boe (USFS) collected DNA samples from bull trout and steelhead in Mill Creek, and Wilbur Wagoner collected DNA samples from steelhead on Yellowhawk Creek. Jon Germond (ODFW) and his staff collected DNA samples from steelhead and bull trout in the upper Walla Walla River. Jim Shaklee was in charge of DNA analyses. We thank all of them.

Steve Martin, Joe Bumgarner, Charlie Craig, John Covert and Bill Neve reviewed a draft of this report and provided comments for revision of the final draft. We appreciate their assistance in preparation of this report. 


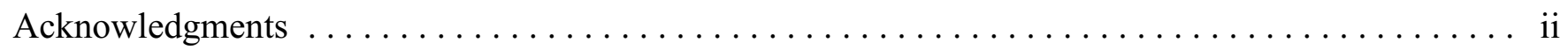

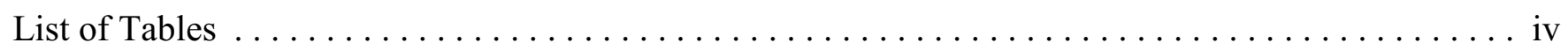

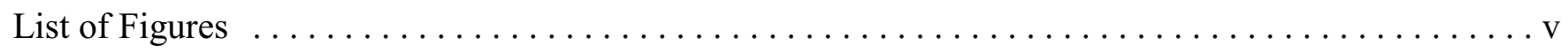

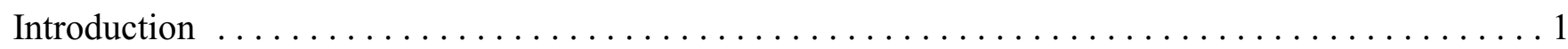

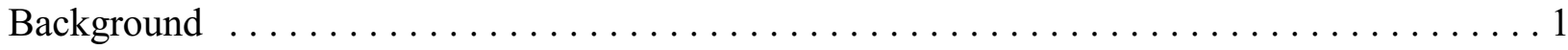

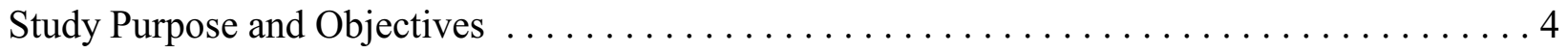

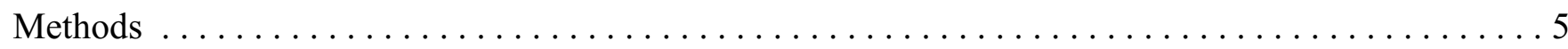

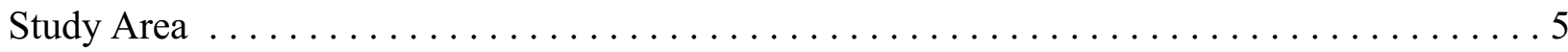

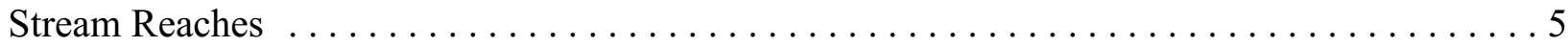

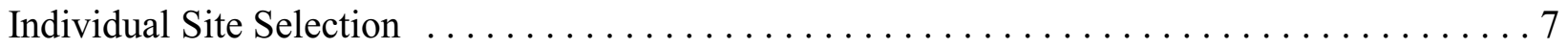

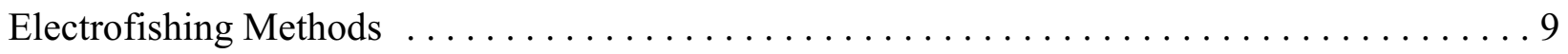

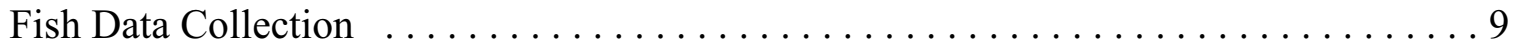

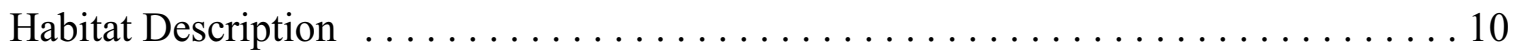

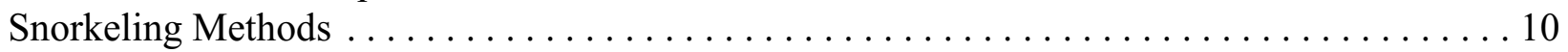

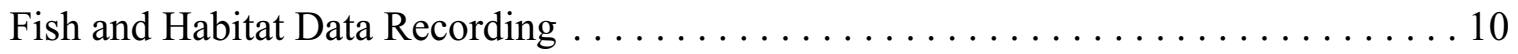

Temperature and Flow Measurements . . . . . . . . . . . . . . . . . . . . . . 10

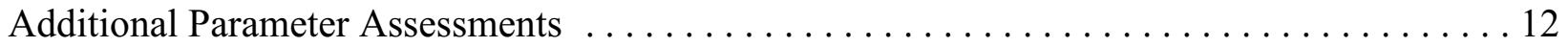

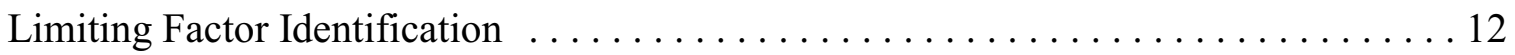

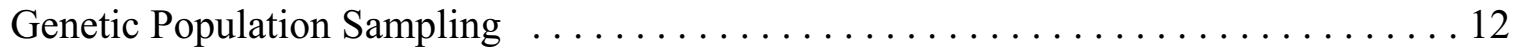

Data Analysis ............................................. 13

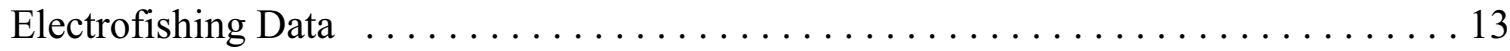

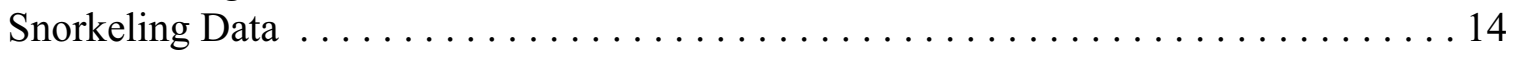

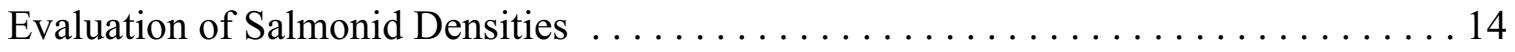

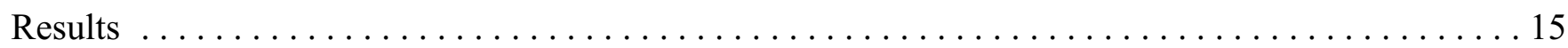

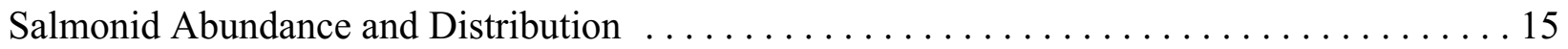

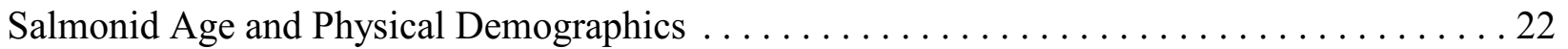

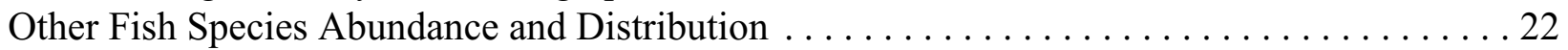

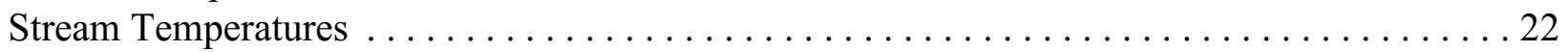

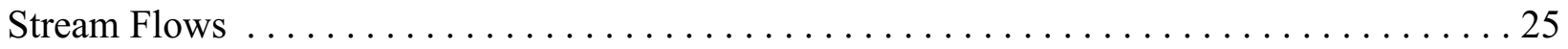

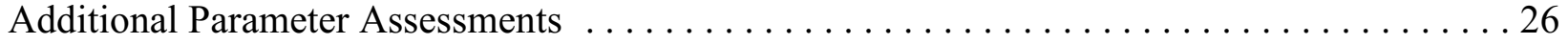

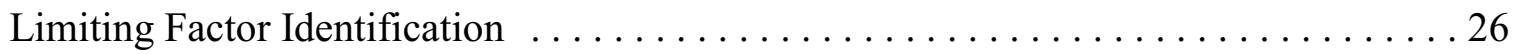

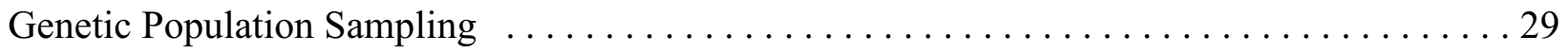

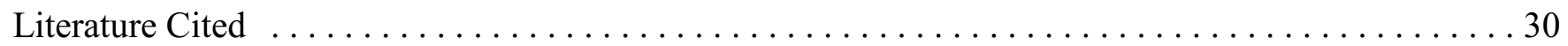

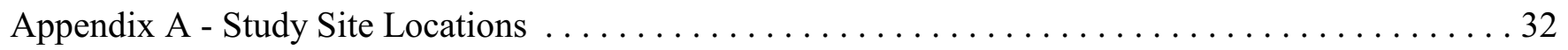

Appendix B - Daily Summaries of Instream Temperature and Flow Data $\ldots \ldots \ldots \ldots \ldots \ldots \ldots$ 


\section{List of Tables}

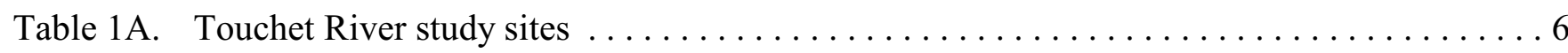

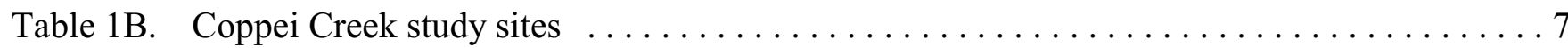

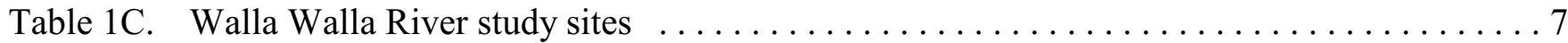

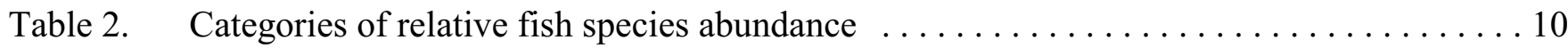

Table 3. Densities of rainbow/steelhead from electrofishing sites in the Walla Walla River and Coppei Creek, a tributary of the Touchet River, summer and fall $1998 \ldots \ldots \ldots \ldots 15$

Table 4. Densities of salmonids from electrofishing sites in the Touchet River and some

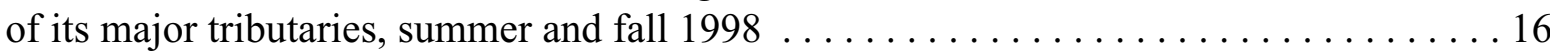

Table 5. Densities of salmonids from snorkeling sites on the Touchet and Walla Walla

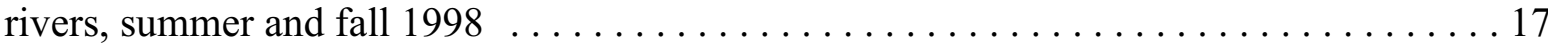

Table 6. Biomass of salmonids from electrofishing sites in the Walla Walla River and

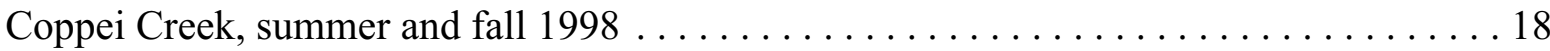

Table 7. Biomass of salmonids from electrofishing sites in the Touchet River, summer

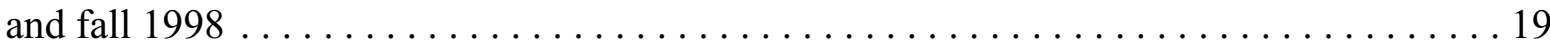

Table 8. Monthly temperature means for instream monitoring sites and mean salmonid

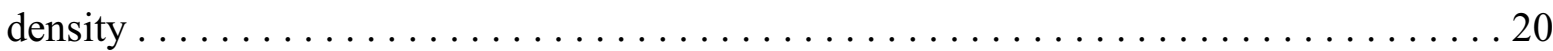

Table 9. Non-salmonid species average abundance in specified reaches $\ldots \ldots \ldots \ldots \ldots \ldots \ldots 28$

Table 10. Stream reaches with suspected thermal barriers to salmonid passage or

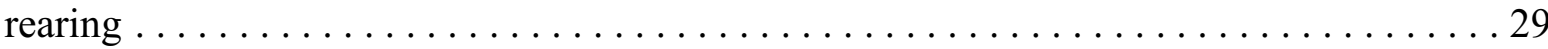




\section{List of Figures}

Figure 1. Walla Walla River watershed $\ldots \ldots \ldots \ldots \ldots \ldots \ldots \ldots \ldots \ldots \ldots \ldots \ldots \ldots$

Figure 2. Relative locations of electrofishing and snorkeling sites in the Walla Walla Basin, 1998 . 8

Figure 3. Relative locations of temperature and flow monitoring sites in the Walla Walla Basin,

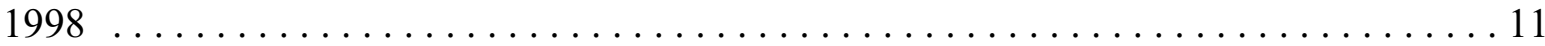

Figure 4. An example of a histogram for the mainstem Touchet River used to distinguish rainbow

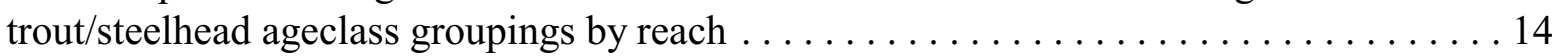

Figure 5. Total salmonid densities on the Touchet River, in relation to river mile $\ldots \ldots \ldots 21$

Figure 6. Total salmonid densities on the Walla Walla River, in relation to river mile . . . . . . 21

Figure 7. Daily mean temperatures at four instream monitor sites on the mainstem

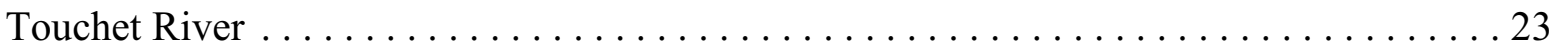

Figure 8. Daily mean temperatures at four instream monitor sites on the mainstem Touchet River,

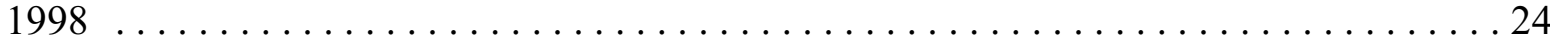

Figure 9. Daily mean temperatures on tributary streams and forks $\ldots \ldots \ldots \ldots \ldots \ldots \ldots$

Figure 10. Instream flows at selected sites in the Walla Walla Basin, $1998 \ldots \ldots \ldots \ldots \ldots \ldots$ 


\section{Introduction}

Over the past decade, interest and concern over the decline of native salmon and trout has increased among natural resource managers and the public. This interest has coalesced into a multitude of initiatives at the local, state and federal levels, leading to the development of projects that are directed toward restoring declining salmon populations and their habitat. Added to the mix is the listing, under the Endangered Species Act (ESA), of several populations of salmonids as "Threatened." Listings under the ESA will compel resource agencies and other entities whose activities impact the habitat and survival of salmonid fishes to develop management plans for protection and enhancement of these biologically, ecologically, and culturally important fishes.

The Washington Department of Fish and Wildlife (WDFW) is entrusted with "the preservation, protection, and perpetuation of fish and wildlife.... [and to] maximize public recreational or commercial opportunities without impairing the supply of fish and wildlife (WAC 77.12.010)." In consideration of this mandate the WDFW submitted a proposal in December 1997 to the Bonneville Power Administration (BPA) for a study to assess salmonid distribution, relative abundance, genetics, and the condition of their habitats in the Walla Walla River basin.

The study reported herein details the findings of the 1998 field season. The 1998 field season extended from mid-June to mid- November. The study is proposed to continue through the year 2002.

\section{Background}

The Walla Walla River and its major tributaries, including the Touchet River, comprise a watershed of 1,758 square miles (ACOE 1997) and 2,454 major stream miles (Knutson et al. 1992). The majority of the watershed (73\%) lies within Washington State, with the remainder in Oregon (Figure 1). The Walla Walla River originates from a fine network of deeply incised streams on the western slopes of the Blue Mountains. The Touchet River originates from similar streams on the northwestern slopes of the Blue Mountains, and also from seasonal streams draining Palouse hillsides to the north. The Walla Walla River drains into the Columbia River near Wallula Gap, about 21 miles above McNary Dam and 6 miles above the Oregon border. The Touchet river drains into the Walla Walla River at river mile (RM) 21.6, near the town of Touchet.

Major geologic events that shaped the basin include the formation of massive fault zones: the Wallula Fault which demarcs the southwestern boundary of the watershed, and the Hite Fault, which contributes to the eastern boundary (Carson and Pogue 1996). Anticlinal ridges associated with volcanic events along these faults created relief features that influence the shape of the basin. These ridges also influenced the direction of flow of colossal flood waters released during a series of events known as the Missoula Floods, which occurred approximately 15,000 years ago (Carson and Pogue 1996, Spencer 1989). The Missoula Floods left extensive gravel-imbedded deposits known as Touchet Beds. The present day courses of the Walla Walla and Touchet Rivers cut through several Touchet Bed formations (Spencer 1989). Other relatively recent geologic events that influence the physiologic character of the basin today include: the deposition of wind blown silt loess upon basalt ridges, forming the smoothly 


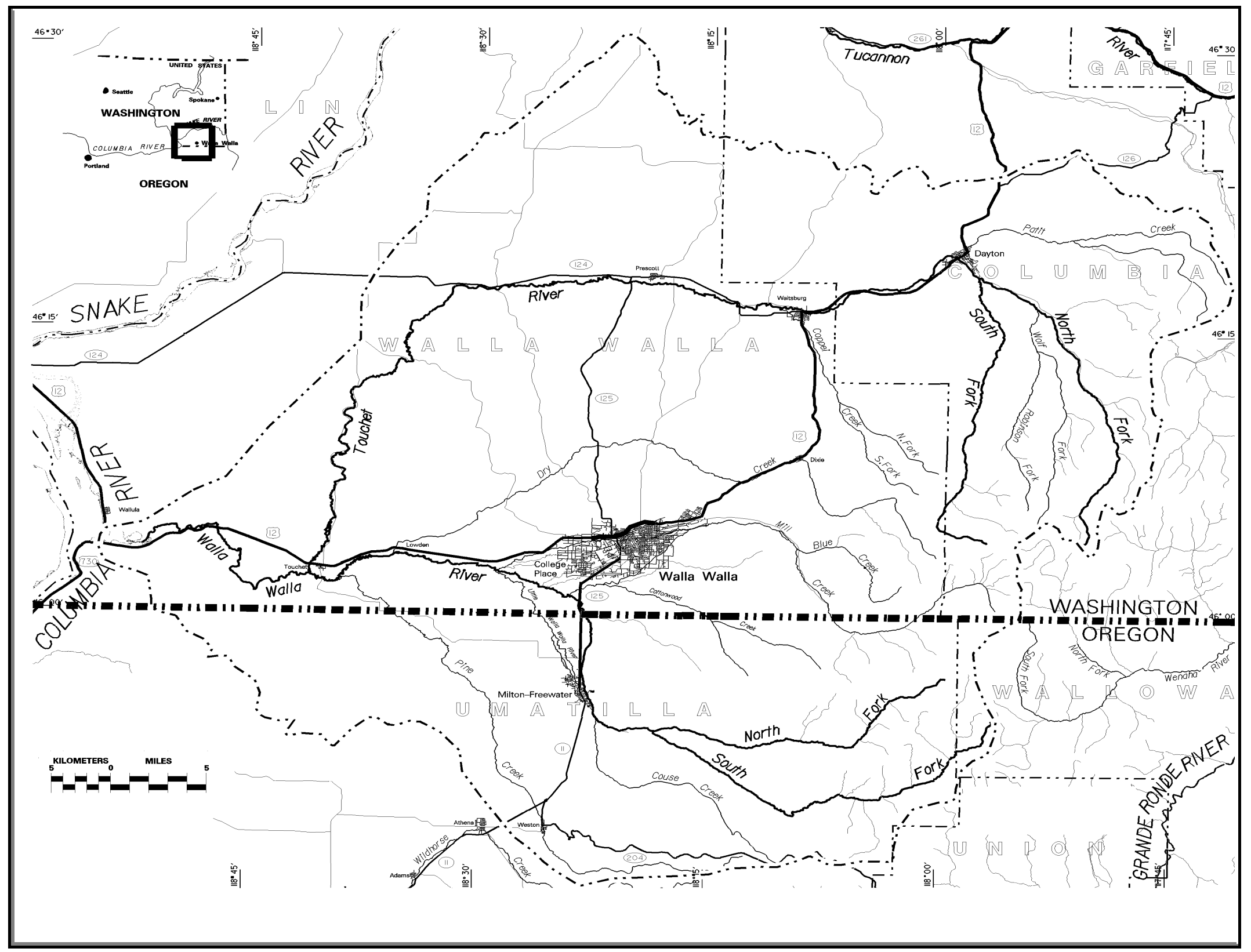

Figure 1. Walla Walla River watershed (modified from map courtesy of USACE, Walla Walla District). 
undulating Palouse foothills (Franklin and Dyrness 1973); and periodic flooding events that formed the broad floodplains of the mainstem Touchet and Walla Walla rivers (Carson and Pogue 1996).

The geomorphology of the watershed exerts a strong influence on biologic conditions for fish within streams and rivers. Gravels contributed by Touchet Beds from flooding events are available for spawning and rearing habitat. Basaltic reefs and boulder fields provide instream cover for salmon and other fishes, and also contribute to pool formation. Highly erodible Palouse loess contributes to a relatively large fine sediment load during high flows (ACOE 1992, 1997), which may deter salmonid upstream migration and smother eggs and young (Hicks et al. 1991).

The original vegetation of the mountainous headwaters consisted of mosaic plant communities of ponderosa pine, lodgepole pine, Englemann spruce, and dense chaparral-like shrub communities (Franklin and Dyrness 1973). Fire maintained a relatively open understory in the forested communities. Present day vegetation in these areas is similar, but somewhat altered by logging and fire suppression. The original vegetation of the Palouse hills, which cover the majority of the watershed, was grassy steppe, dominated by bunch grasses and annual forbs. Unaltered stands of this unique plant community are now extremely rare. Since the mid-1800s, the majority of Palouse steppe has been converted to wheat and other crops, or livestock grazing (Franklin and Dyrness 1973, Lindeman 1992). Original riparian vegetation along streams and rivers in the region consisted of dense thickets of cottonwood and other deciduous trees and woody shrubs; this vegetative community is also now rare, and remnant stands are usually fragmented and disjunct from each other (Tabor 1976, field observation). Traditional agricultural practices lead to the clearing of nearly all riparian tracts and frequent grazing of the remainder (ACOE 1997, Lindeman 1992). Perhaps a harbinger of the decline of this vegetative community, the yellow-billed cuckoo, a species dependent on extensive riparian forests, and once common throughout the region, is now extirpated in Washington State (Smith et al. 1997).

Historic and contemporary land-use practices have had a profound impact on the kind, abundance and distribution of anadromous salmonids in the watershed. Fish habitat in area streams has been severely degraded by urban and agricultural development, grazing, tilling, logging, recreational activities, and flood control structures. Sixty percent of current water usage in the basin is for irrigating crops (ACOE 1997) and irrigation has severely impacted stream flows in the Walla Walla River since the 1880's (Neilson 1950). Approximately $99 \%$ of the surface water in the Walla Walla River within Washington State is used for irrigation (Bill Neve, Dept. of Ecology, pers. communication).

Out-of-basin impacts to local fish populations have been substantial. Salmon migrating to or from the ocean must pass through four dams on the Columbia River before reaching their destination. Juvenile salmonid mortality at each dam is estimated at 4-5\% (Committee et al. 1996), and from 5-14\% of migrating adult salmon are killed as they pass through each dam (Collier et al. 1996). Other past out-ofbasin impacts include over-harvest, habitat destruction in the lower Columbia and estuaries, unscreened and poorly screened diversions throughout the system, and toxic spills.

Historically the basin produced substantial runs of both spring chinook and summer steelhead. The last substantial run of wild chinook took place in 1925; thereafter chinook populations continued a precipitous decline, and the species is considered extirpated in the basin (Neilson 1950, ACOE 1997). Endemic steelhead persist throughout much of the basin, but the population is considered depressed 
(WDF and WDW 1993). Annually, non-endemic stock steelhead are released in the basin under the Lower Snake River Compensation Program (LSRCP) to provide harvest mitigation for the four lower Snake River dams. Chum and coho salmon may have also occurred in the drainage before the early 1900 's, but written documentation is scanty or lacking. Anecdotal accounts and reports of historic fisheries in adjacent basins, indicate that chum and coho could have occurred in substantial numbers in the Walla Walla Basin (Pirtle 1957).

Native salmonids that do not migrate to the ocean are also present. However, only rainbow trout retain a wide distribution throughout upper and lower portions of the watershed. Bull trout are thought to have been widely distributed in the basin prior to agricultural settlement and the clearing of streamside trees and irrigation water withdrawal that raised water temperatures beyond the tolerance of this cold water species (Mongillo 1993). Today, bull trout distribution is currently limited to montane upper tributaries of the Touchet River, Walla Walla River, and Mill Creek (Mongillo 1993).

Several non-native fish species have been introduced to support a recreational fishery or have strayed into the basin. Carp were introduced as early as 1884 (Walla Walla Daily Journal 1884). Channel catfish, smallmouth bass, and bluegill are some of the warm water fish that now occur in the basin. The Washington Department of Game (now WDFW) began stocking brown trout (Salmo trutta), a native of northern Europe, in the Touchet River in the 1960's. Stocking was discontinued in 1999 due to concerns about competition, hybridization, and predation of native bull trout and steelhead.

\section{Study Purpose and Objectives}

The purpose of the study is to determine fish passage, rearing, and spawning conditions for steelhead and potential reintroduction of chinook salmon, and to assess steelhead and bull trout distribution, densities, and genetic composition in the Walla Walla watershed.

Specific objectives and tasks were outlined in WDFW's proposal and statement of work to the BPA (Project \# 98-20). Some tasks had to be scaled back or postponed to the 1999 field season because of budgetary constraints, and a late start of the field season due to a lengthy process to establish the project, hire personnel and purchase equipment. More extensive habitat data collection and the addition of steelhead spawning surveys are anticipated in 1999 because of time savings resulting from the reduction or elimination of some start-up activities (such as purchasing equipment) and an earlier start date. Multi-year study objectives include:

1. Assess baseline habitat conditions for salmonids in the Washington portion of the Walla Walla Watershed.

2. Determine salmonid distribution and relative abundance in the Washington portion of the Walla Walla watershed.

3. Identify genetic stocks of steelhead and bull trout in the Walla Walla watershed. 


\section{Methods}

Specific objectives and tasks were outlined in the statement of work in Contract 98-20. Tasks included:

- Establish constant recording temperature and flow monitors in the Touchet, and Walla Walla, to identify available water for salmon passage and rearing, as well as temperature limitations for salmonid passage, spawning and rearing.

- Conduct biweekly manual stream flow and temperature measurements to calibrate instream monitor data outputs, and to provide data for reaches that did not have instream monitors.

- Conduct electrofishing or snorkel surveys during summer to determine salmonid distribution, abundance, and habitat use.

- Conduct periodic flights of the lower Walla Walla and Touchet rivers to determine continuity of stream flows for adequate fish passage and rearing.

- Conduct general habitat surveys in portions of the stream with potential for salmonid use to quantify habitat conditions and identify limiting factors (This task was deferred in 1998).

- Conduct steelhead and bull trout spawning surveys (steelhead spawning surveys were not conducted in 1998 because of the delayed start of the field season).

- Develop cooperative arrangements to collect DNA samples from bull trout and steelhead for genetic population analysis.

\section{Study Area}

The study area encompasses the greater Walla Walla River basin in Washington State (Figure 1). The Walla Walla, and the Touchet which flows into it, are the major rivers in the basin. The 1998 study area includes the mainstems of the Touchet and Walla Walla rivers, as well as six tributary systems: (1) North Fork, South Fork, Wolf Fork and Robinson Fork of the Touchet River; (2) Coppei Creek and its headwaters, a tributary of the Touchet River; and, (3) Yellowhawk Creek, a tributary of the Walla Walla River.

\section{Stream Reaches}

Representative reaches were identified for the two major river systems, based on general physical characteristics and readily identifiable landmarks. General physical characteristics included: slope, width, depth, and temperature; as well as, predominant adjacent land uses. Landmarks included towns, roads, and bridges (Table 1). 
Table 1A. Touchet River system study sites. A detailed description of each site is available in Appendix A.

\begin{tabular}{|c|c|c|c|c|}
\hline Reach & Site \# & Landmark $^{1}$ & River Mile & Sampling $^{2}$ \\
\hline North Fork & $\begin{array}{l}\text { NFT-1 } \\
\text { NFT-2 } \\
\text { NFT-3 } \\
\text { NFT-4 } \\
\text { NFT-5 } \\
\text { NFT-6 } \\
\end{array}$ & $\begin{array}{l}\text { Sno-Park } \\
\text { US Forest Serv. Bndry } \\
\text { Snake R Lab NF\#1 } \\
\text { Snake R Lab NF\#2 } \\
\text { Snake R Lab NF\#3 } \\
\text { Jim Creek Confluence }\end{array}$ & $\begin{array}{l}7.3 \\
13.1 \\
11.2 \\
5.8 \\
0.35 \\
8.0 \\
\end{array}$ & $\begin{array}{l}\text { E } \\
\text { TM, E } \\
\text { E } \\
\text { E } \\
\text { E } \\
\text { TM } \\
\end{array}$ \\
\hline South Fork & $\begin{array}{l}\text { SFT-1 } \\
\text { SFT-2 } \\
\text { SFT-3 }\end{array}$ & $\begin{array}{l}\text { Snake R Lab SF\#1 } \\
\text { Snake R Lab SF\#2 } \\
\text { Snake R Lab SF\#3 }\end{array}$ & $\begin{array}{l}11.4 \\
8.0 \\
2.5 \\
\end{array}$ & $\begin{array}{l}\mathrm{E} \\
\mathrm{E} \\
\mathrm{E}\end{array}$ \\
\hline Wolf Fork & $\begin{array}{l}\text { WFT-1 } \\
\text { WFT-2 } \\
\text { WFT-3 }\end{array}$ & $\begin{array}{l}\text { Snake R Lab WF\#1 } \\
\text { Snake R Lab WF\#2 } \\
\text { Snake R Lab WF\#3 }\end{array}$ & $\begin{array}{l}9.3 \\
2.9 \\
1.6 \\
\end{array}$ & $\begin{array}{l}\mathrm{E} \\
\mathrm{E} \\
\mathrm{E}\end{array}$ \\
\hline Robinson Fork & $\begin{array}{l}\text { RFT-1 } \\
\text { RFT-2 }\end{array}$ & $\begin{array}{l}\text { Broughton Land Co Gate } \\
\text { Lower Robinson Fk }\end{array}$ & $\begin{array}{l}2.4 \\
1.2 \\
\end{array}$ & $\begin{array}{l}\mathrm{E} \\
\mathrm{E}\end{array}$ \\
\hline Mainstem Reach 1 & $\begin{array}{l}\text { TR-1 } \\
\text { TR-2 } \\
\text { TR-3 } \\
\text { TR-4 } \\
\text { TR-5 } \\
\text { TR-6 } \\
\text { TR-7 } \\
\text { TR-8 } \\
\text { TR-9 } \\
\text { TR-10 } \\
\text { TR-11 } \\
\text { TR-12 }\end{array}$ & $\begin{array}{l}\text { 100' below SF confluence } \\
\text { Upper Dayton Dike } \\
500 \text { ' above spillway } \\
\text { Snake River Lab intake } \\
\text { Playing Field Flagpole } \\
\text { Hwy } 12 \text { Br. ,Dayton } \\
\text { Golf Course } \\
\text { Rd } 2441 \\
\text { County Farm Rd. } \\
\text { Payne Hollow \#1 } \\
\text { Payne Hollow \#2 } \\
\text { Above Rose Gulch }\end{array}$ & $\begin{array}{l}61.9 \\
61.6 \\
60.9 \\
60.7 \\
60.6 \\
60.3 \\
59.2 \\
58.4 \\
58 \\
57.3 \\
57 \\
56.1 \\
\end{array}$ & $\begin{array}{l}\text { S } \\
\text { E } \\
\text { S } \\
\text { TM } \\
\text { T, F } \\
\text { E } \\
\text { E, S } \\
\text { E } \\
\text { S } \\
\text { S } \\
\text { S } \\
\text { E }\end{array}$ \\
\hline Mainstem Reach 2 & $\begin{array}{l}\text { TR-13 } \\
\text { TR-14 } \\
\text { TR-15 } \\
\text { TR-16 }\end{array}$ & $\begin{array}{l}\text { Lewis \& Clark State Pk } \\
\text { Hogeye Hollow Rd. } \\
\text { Waitsburg City Park } \\
\text { Aylsward Rd }\end{array}$ & $\begin{array}{l}54.7 \\
52.2 \\
50 \\
49.3 \\
\end{array}$ & $\begin{array}{l}\text { TM, E, S } \\
\text { E, S } \\
\text { E, S } \\
\text { S }\end{array}$ \\
\hline Mainstem Reach 3 & $\begin{array}{l}\text { TR-17 } \\
\text { TR-18 } \\
\text { TR-19 } \\
\text { TR-20 } \\
\text { TR-21 } \\
\text { TR-22 } \\
\text { TR-23 } \\
\text { TR-24 } \\
\text { TR-25 } \\
\end{array}$ & $\begin{array}{l}\text { Knotgrass Rd } \\
\text { Wood's Xing } \\
\text { Bolles Bridge } \\
\text { Lower Bolles } \\
\text { Hart Rd } \\
\text { Flathers Bridge } \\
\text { Pettyjohn Bridge } \\
\text { Lamar } \\
\text { Burlington Northern } \\
\end{array}$ & $\begin{array}{l}48.1 \\
47.9 \\
45.9 \\
44.9 \\
41.6 \\
38.2 \\
34.5 \\
31 \\
27.7 \\
\end{array}$ & $\begin{array}{l}\text { TM, T, F ,E } \\
\text { E, S } \\
\text { T, F, S } \\
\text { E } \\
\text { E } \\
\text { E } \\
\text { E } \\
\text { TM, T, F, E } \\
\text { E }\end{array}$ \\
\hline Mainstem Reach 4 & $\begin{array}{l}\text { TR-26 } \\
\text { TR-27 } \\
\text { TR-28 } \\
\end{array}$ & $\begin{array}{l}\text { Hoffman Rd } \\
\text { Plucker Bridge } \\
\text { Simms Rd. }\end{array}$ & $\begin{array}{l}23.5 \\
15.4 \\
12.4 \\
\end{array}$ & $\begin{array}{l}\mathrm{E} \\
\mathrm{E} \\
\mathrm{TM}, \mathrm{T}, \mathrm{F}, \mathrm{E} \\
\end{array}$ \\
\hline Mainstem Reach 5 & $\begin{array}{l}\text { TR-29 } \\
\text { TR-30 } \\
\text { TR-31 }\end{array}$ & $\begin{array}{l}\text { Johnson Bridge } \\
\text { Legrow Rd. } \\
\text { Touchet Gunclub }\end{array}$ & $\begin{array}{l}8.7 \\
5.8 \\
3.2 \\
\end{array}$ & $\begin{array}{l}\text { E } \\
\text { E } \\
\text { TFM, T, F, E }\end{array}$ \\
\hline
\end{tabular}

1. Descriptive location, usually the nearest public road or facility.

2. Key: TFM = instream temperature and stage monitor site ; $\mathrm{TM}=$ instream temperature monitor site; 


\begin{tabular}{ccccc}
\hline Reach & Site \# & Landmark $^{1}$ & River Mile & Sampling $^{2}$ \\
\hline $\mathrm{T}=$ manual temperature site; & $\mathrm{F}$ & $=$ & manual flow site; & $\mathrm{E}=$ electrofishing site $; \mathrm{S}=$ snorkeling site.
\end{tabular}

Table 1B. Coppei Creek study site.

\begin{tabular}{lllll}
\hline Reach & Site \# & Landmark & River Mile & Sampling $^{\mathbf{2}}$ \\
\hline \multirow{2}{*}{ North Fork } & NFC-1 & DNR Gate & 5.2 & E \\
& NFC-2 & NF Coppei \#2 & 1.8 & E \\
& NFC-3 & Haystack & 0.5 & E \\
\hline \multirow{2}{*}{ South Fork } & SFC-1 & Barnes Rd & 5.1 & E \\
& SFC-2 & Geir Rd & 3.7 & E \\
& SFC-3 & Walker Rd & 0.8 & E \\
& SFC-4 & Lower SF Coppei & 0.4 & E \\
\hline \multirow{2}{*}{ Mainstem } & CC-1 & Coppei Rd Bridge & 4.9 & E \\
& CC-2 & Old Airstrip & 4.1 & E \\
& CC-3 & Meinburg Rd & 1.8 & E \\
& CC-4 & Lower Coppei & 0.5 & TM, E \\
\hline
\end{tabular}

1. Descriptive location, usually the nearest public road or facility.

2. Key: TFM = instream temperature and stage monitor site ; TM = instream temperature monitor site; $\mathrm{T}=$ manual temperature site; $\mathrm{F}=$ manual flow site; $\mathrm{E}=$ electrofishing site; $\mathrm{S}=$ snorkeling site.

Table 1C. Walla Walla study sites.

\begin{tabular}{lllll}
\hline Reach & Site \# & Landmark $^{\mathbf{1}}$ & River Mile & Sampling $^{\mathbf{2}}$ \\
\hline Walla Walla & WW-1 & Peppers Bridge & 30.1 & T, F, E \\
River - Reach 1 & WW-2 & Hwy 125 & 41.2 & S \\
& WW-3 & Old MF Hwy & 40.9 & E \\
& WW-4 & Mojonnier & 40.6 & S \\
\hline Reach 2 & WW-5 & Beet Rd & 38.4 & TFM, T, F, E, S \\
& WW-6 & Last Chance Rd & 37.6 & E, S \\
& WW-7 & Swegle Rd & 36.5 & TFM, T, F, E, S \\
& WW-8 & Detour Rd & 34.4 & E, S \\
& WW-9 & McDonald Rd & 31.6 & TFM, T, F, E, S \\
& WW-10 & Barney Rd & 28 & E \\
& WW-11 & McKay Rd & 24.7 & T, F, E \\
\hline Yellowhawk Creek & YC-1 & Carl St & 6.9 & TM, T \\
& YC-2 & Lower Yellowhawk & 1.6 & TM, T, F \\
\hline
\end{tabular}

1. Descriptive location, usually the nearest public road or facility.

2. Key: TFM = instream temperature and stage monitor site ; $\mathrm{TM}=$ instream temperature monitor site; $\mathrm{T}=$ manual temperature site; $\mathrm{F}=$ manual flow site; $\mathrm{E}=$ electrofishing site; $\mathrm{S}=$ snorkeling site.

\section{Individual Site Selection}

Within representative reaches, three or more electrofishing and/or snorkeling sites were selected. Because nearly the entire lengths of the study streams are in private ownership, it was necessary to obtain permission from landowners to access potential sites. Owners of property bordering the study streams were identified from county assessment records and contacted by mail. Landowners at selected sites had follow up contact by phone or in person, to assure that access was permitted. For convenience, 
state-owned land was utilized when available. Individual sites were selected on the basis of access to sufficiently large property ownership to allow for randomly locating sites. Study sites were distributed to comprehensively cover the mainstem Touchet River, and its largest tributaries, and the mainstem Walla Walla River, from the Oregon State line to Lowden (Figure 2). 


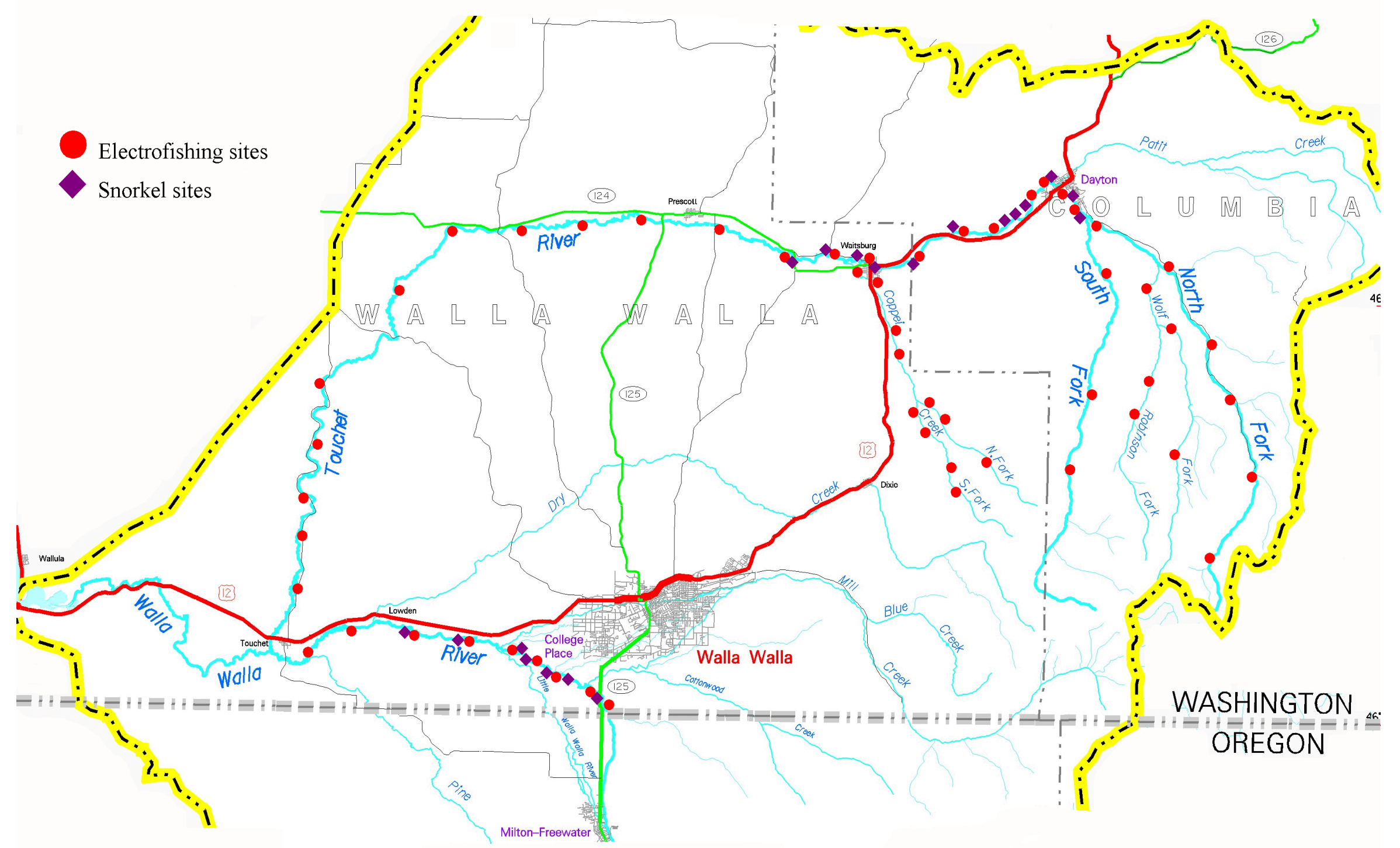

Figure 2. Relative locations of electrofishing and snorkeling sites in the Walla Walla Basin, 1998. 
River mile (RM) locations were determined for study sites and points of relevance: such as towns, bridges, and tributaries. River miles were determined by measuring the course of rivers and streams in a mapping software program, "Street Atlas USA, Version 6", CDeLorme. These locations should be considered approximate, due to the limited precision of this method.

Electrofishing sites were randomly located from selected access areas by using various randomization techniques to locate a point on the stream, and then whether that point would become the location of the upstream or downstream net. Site locations sometimes had to be modified to avoid unsuitable stream features, such as overly deep pools, rapids, and multiple channels. Sites were delimited by block nets, spanning the channel, placed approximately 100 feet apart. Block nets prevented fish from entering or leaving the site, so that fish population density could be calculated (Platts et al. 1983).

Snorkeling sites were designed to extend or compliment the area initially surveyed by electrofishing. Snorkeling could encompass stream features that would be difficult to electrofish, such as deep pools and braided channels. They were located using the same randomization process used for establishing electrofishing sites.

\section{Electrofishing Methods}

A Smith-Root Model 11A or 12B electrofishing backpack unit was used to stun and collect fish in the study site. The minimal voltage needed to stun fish was applied. Voltage varied between 400 and 800 volts. Clearer streams with low conductivity required greater voltage. The operator began at the upstream net and worked downstream, covering the entire wetted width. A "pass" was completed when the downstream net was reached. All sites received at least two sequential passes. A third pass was required if a reduction of $70 \%$ of fish numbers for each salmonid species, in each age class, was not achieved between the first and second pass. Fish were collected with dip nets and placed in instream holding containers until they could be processed.

\section{Fish Data Collection}

Salmonid fishes encountered were collected, identified, weighed and measured for fork length. Salmonids are defined as fishes belonging to the Family Salmonidae. The Salmonidae are characterized by the presence of an adipose fin and fleshy appendage at the base of the abdominal pelvic fins; most genera in the Salmonidae possess some degree of anadromy and saltwater tolerance (Simpson and Wallace 1978). Identification included age class of the individual: age $0+$ is $<1$ year old; age $1+$ is $\geq 1$ year; "legal-sized"is $\geq 8$ in $(200 \mathrm{~mm})$ for rainbow trout.

A representative sampling of 10-20 individuals of other fish species present were also collected,

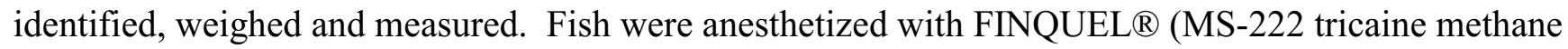
sulfonate) for weighing and measuring procedures. Data were recorded on customized field data sheets. Non-salmonid species were given relative abundance estimates (Table 2). 
Table 2. Categories of relative fish species abundance.

\begin{tabular}{lrr}
\hline Category & $\begin{array}{r}\text { Count } \\
\text { (individuals seen) }\end{array}$ & $\begin{array}{r}\text { Ranking Value } \\
\text { (for averaging sites) }\end{array}$ \\
\hline Absent & 0 & 0 \\
Rare & $1-3$ & 1 \\
Uncommon & $4-10$ & 2 \\
Common & $11-100$ & 3 \\
Abundant & $100+$ & 4 \\
\hline
\end{tabular}

\section{Habitat Description}

Water temperature $\left({ }^{\circ} \mathrm{F}\right)$ was measured at the beginning and ending of sampling, using standard field thermometers. The accuracy of field thermometers was evaluated periodically, using a laboratory calibrated thermometer (Kessler Instruments). Site surface area was determined by a length measurement and the average site width from measurements at 20 foot intervals. Because of time constraints, further habitat evaluation was primarily descriptive in nature.

\section{Snorkeling Methods}

Snorkeling methods differed from electrofishing methods primarily in that sample sites were longer, 200 to 500 feet, and fish were observed but not collected. Snorkelers moved slowly upstream, counting and identifying species, and determining the age class of all salmonid fishes seen underwater. Counts were recorded on armbands or reported to an observer on the bank. Snorkeling was conducted at sites from Dayton to Bolles Junction, about four miles west of Waitsburg, on the Touchet River; and, from the Oregon border to McDonald Road on the Walla Walla River.

\section{Fish and Habitat Data Recording}

Data recording during snorkeling was the similar to electrofishing, except that weights and lengths were unavailable. Determining species of dace, sculpins and suckers also was not possible. Age classes and relative abundance were recorded similarly to electrofishing data. Habitat description was the same as on electrofishing sites.

\section{Temperature and Flow Measurements}

Temperatures and flows were recorded throughout the two river systems by two methods (Figure 3 ). The first method was manual data collection. Temperatures were taken with standard field thermometers and recorded on log sheets. Manual discharge measurements were taken according to standard methods (Armour and Platts 1983). Discharge was calculated later in cubic feet per second (cfs) in Quattro Pro@ spreadsheets. Manual temperatures and discharge measurements were taken at ten specified sites on a bi-weekly basis (Table 1, Figure 3). Manual temperatures were taken at all sites visited during electrofishing and snorkeling surveys. 


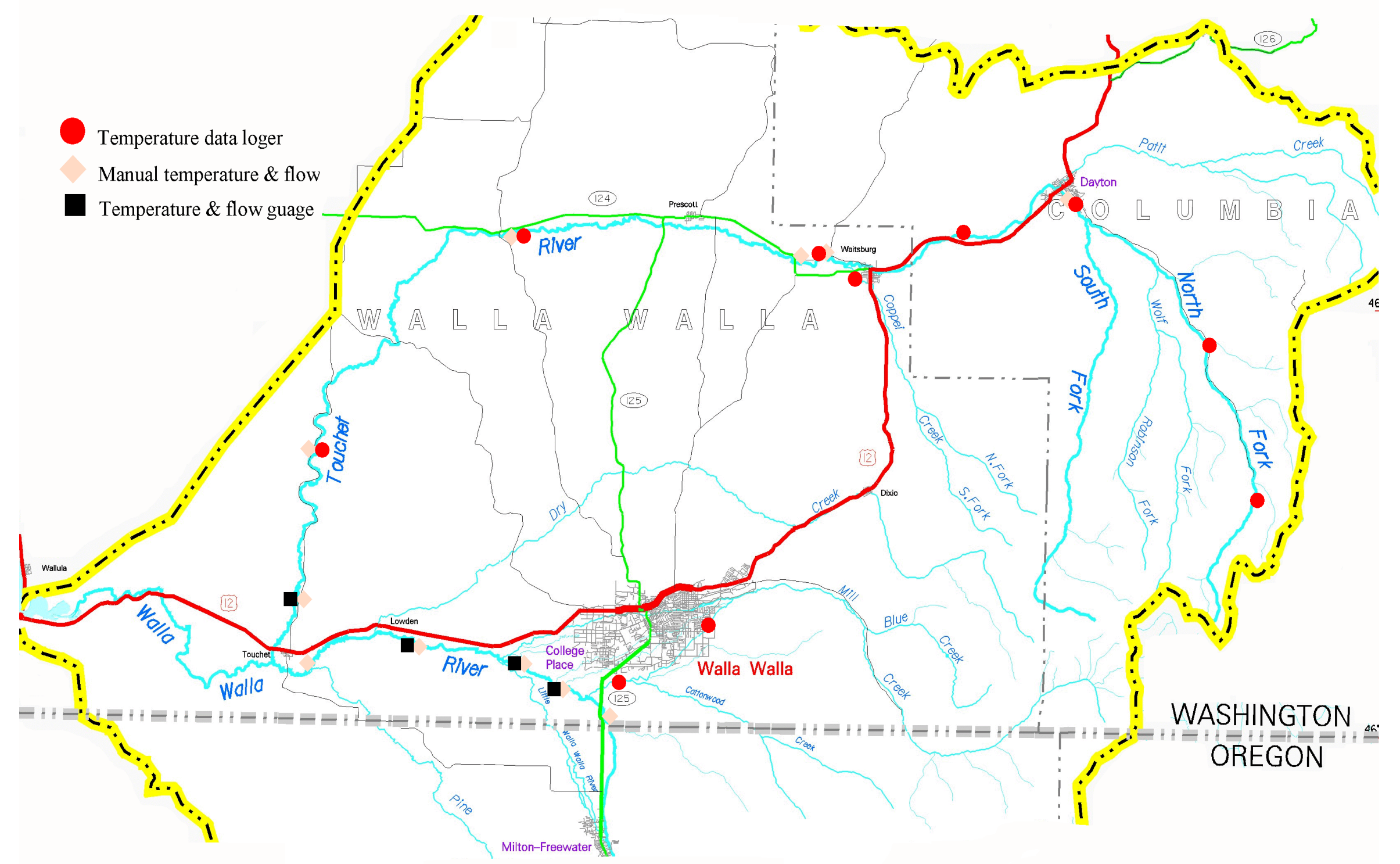

Figure 3. Relative locations of temperature and flow sites in the Walla Walla Basin, 1998. 
The second method consisted of automated instream monitoring. In cooperation with the Washington State Department of Ecology (WDOE), monitors for the continuous measurement of flow and temperature (Unidata America, Model KB/DSP 128K) were placed at three locations on the Walla Walla River and one on the lower Touchet River (Table 1, Figure 3). The WDOE maintained these monitors and downloaded their data. The WDFW took periodic manual flow measurements near each of the WDOE monitors to verify the relation of discharge and monitor pressure readings.

Monitors which continuously measured temperature only (Onset Corporation, Optic StowAway Temp®) were placed at nine sites (Table 1, Figure 3). The WDFW maintained the temperature monitors and periodically downloaded their data.

\section{Additional Parameter Assessments}

\section{Limiting Factor Identification}

One of the study goals was to identify and document physical barriers to salmon passage, spawning and rearing. Field personnel noted the presence of potential barriers as part of site visits. The activity of two major irrigation diversion structures, Hofer Dam on the Touchet River, and Burlingame Diversion on the Walla Walla River, were also noted throughout the season.

Physiological barriers to salmonid passage and survival, in the form of excessive temperatures, were also identified by examining tables and graphs of data collected by instream monitors and manual sampling. Maximum temperatures, as well as number of days with temperatures exceeding $75^{\circ} \mathrm{F}$ (lethal to salmon if prolonged), and presence or absence of salmonid fishes at reach study sites, were factors taken into consideration.

On September 29, WDFW biologists conducted an aerial flight to survey water level conditions throughout most of the Walla Walla Basin. The flight followed the river mainstem from the Oregon state line to the river's mouth at Wallula. The condition of mainstem tributaries, such as Garrison Creek, Cold Creek, and Dry Creek, could be observed. The flight also covered the lower reaches of Mill and Yellowhawk Creeks, which are major tributaries to the Walla Walla River, and flow through the City of Walla Walla.

Additional flights to observe the lower Touchet River and other potential habitat-limiting sites had to be deferred to 1999 because of time constraints.

\section{Genetic Population Sampling}

Limited sampling of salmonid DNA was undertaken by cooperating agencies and volunteer personnel. Fin clips were obtained from juvenile and adult steelhead and adult bull trout collected at established fish traps. Fin clips provided sufficient DNA material for genetic analysis, without killing the fish (Olsen et al. 1996). A non-lethal method of genetic sampling was indicated because bull trout are currently listed as Threatened under the Endangered Species Act (ESA), and wild steelhead were potential candidates for listing under the ESA. 
US Forest Service personnel collected bull trout fin clips from fish trapped on upper Mill Creek, east of the city of Walla Walla. Oregon Department of Fish and Wildlife personnel collected steelhead fin clips at the Nursery Bridge irrigation diversion fish trap, located just south of the Washington/Oregon border in Milton-Freewater. Wib Wagner, a long-time volunteer for the WDFW, collected steelhead fin clips at the Mill Pond Diversion fish trap, located on Yellowhawk Creek just upstream of the Walla Walla city limits.

Fin clips from the dorsal or anal fins were labeled and placed in ethanol for preservation and transport to the WDFW Genetics Stock Identification Lab in Olympia. Genetic typing is done by separating cellular DNA into small, repeating nucleotide units, known as "microsatellites" (Olsen et al. 1996). Unique assortments of microsatellites indicate unique genetic stocks of a given fish species (Olsen et al. 1996).

\section{Data Analysis}

Raw data from field data sheets were entered into spreadsheets for purposes of organization, summarization and statistical treatment.

\section{Electrofishing Data}

Electrofishing yielded several data sets: (1) salmonid species distribution and abundance, fish length and weight; (2) non-salmonid species relative abundance, length and weight; and, (3) site dimensions and general habitat characteristics.

Frequency distributions of salmonid fork lengths, by species and stream reach, were calculated and plotted (Figure 4). Visual inspection of histograms was used to identify age classes for each species. Age class groupings were specific to the stream reach. After age classes were identified, individuals were sorted into appropriate age classes and their weights averaged, to determine an average weight per age class.

Lengths and weights were used with a removal-depletion methodology software program developed by the U.S. Forest Service (Van Deventer and Platts, 1983) to calculate population densities (\#/100 $\mathrm{m}^{2}$ ) and biomass for each salmonid species by age class, in each designated site.

Relative abundance data on non-salmonid species was treated semi-quantitatively. For each species in each site, a relative abundance was determined. The relative abundance was assigned a corresponding ranking value (Table 2). Ranked values were averaged, to determine a relative abundance for each species, per designated reach. Relative abundance data was tabulated, to provide qualitative comparisons between reaches and species.

Due to the late start of this project the data collection for habitat variables was not uniform. Quantitative habitat data collection will be performed in subsequent years of this study. 


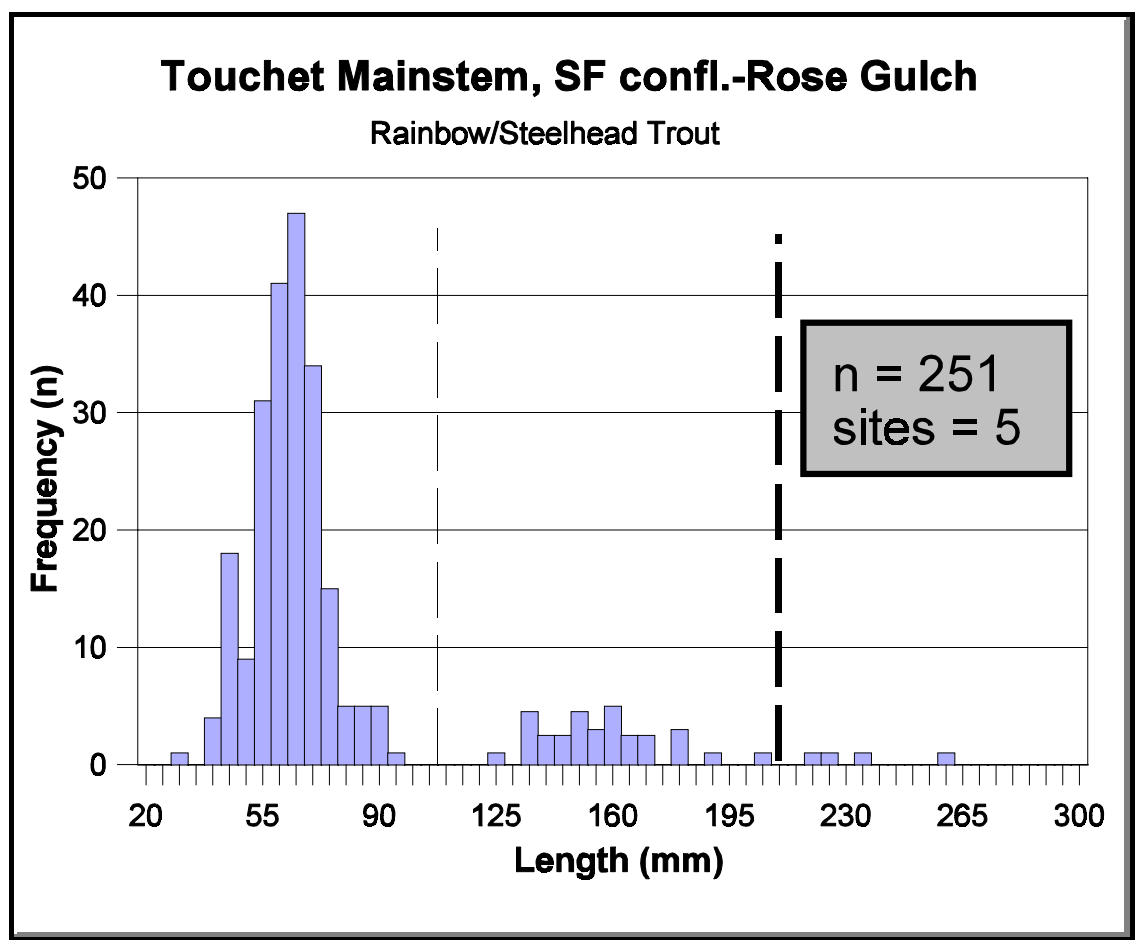

Figure 4. An example of a histogram for the mainstem Touchet River (between the South Fork confluence and Rose Gulch) used to distinguish rainbow trout/steelhead age class groupings $(0+, 1+$, and "legals") by reach.

\section{Snorkeling Data}

Salmonid fishes observed during snorkeling were recorded as age "0+", "1+", and "legals/adult"( $\geq 8$ in) age groups. Salmonid density $\left(\# / 100 \mathrm{~m}^{2}\right)$ of stream surface area, was calculated for each species and age class.

\section{Evaluation of Salmonid Densities}

Snorkeling and electrofishing data were pooled for evaluation of salmonid density vs temperature and salmonid density vs river mile on the Walla Walla River. Electrofishing data was used alone for comparison of salmonid density and river mile on the Touchet River.

Salmonid density was determined for comparison with temperature and river mile by averaging total salmonid density found at the instream monitor site with densities found at the nearest electrofishing or snorkeling site upstream and downstream of the monitor. This generally involved averaging three values, except where a downstream site was unavailable (Coppei Creek and Touchet Gunclub), or where the monitor site itself was not sampled (Dayton). In those cases, two values were averaged. Mean monthly temperature was determined by averaging daily means. 


\section{Salmonid Abundance and Distribution}

Densities and biomass of five salmonid species, within the family Salmonidae, were calculated from stream electrofishing and snorkeling surveys (Tables 3 to 7). Species identified included: mountain whitefish (Prosopium williamsoni), brown trout (Salmo trutta), bull trout (Salvelinus confluentus), rainbow trout/steelhead (Oncorhynchus mykiss), and chinook salmon (Oncorhynchus tshawytscha).

Rainbow/steelhead trout were ubiquitous where salmonids were found. Other species had restricted distribution. Bull trout were found only on the North and Wolf Forks of the Touchet River. Mountain whitefish were only found in the Touchet River, from Dayton upstream. Brown trout were found in three of the four forks upstream of Dayton and in the mainstem Touchet River between Dayton and Waitsburg.

Table 3. Densities of rainbow/steelhead trout from electrofishing sites in the Walla Walla River, and Coppei Creek, a tributary of the Touchet River, summer and fall 1998. Sites with salmonids are listed in upstream to downstream order. Unlisted sites on the Walla Walla River are omitted as no salmonids were detected at these locations.

\begin{tabular}{|c|c|c|c|c|c|c|c|}
\hline \multirow{3}{*}{$\begin{array}{l}\text { Stream Reach/ } \\
\text { Site Name }\end{array}$} & \multirow{3}{*}{$\begin{array}{r}\text { Site } \\
\text { Length (m) }\end{array}$} & \multirow{3}{*}{$\begin{array}{r}\text { Mean } \\
\text { Width }(\mathrm{m})\end{array}$} & \multirow{3}{*}{$\begin{array}{r}\text { Area } \\
\left(\mathbf{m}^{2}\right)\end{array}$} & \multicolumn{4}{|c|}{ Densities $\left(\# / \mathbf{1 0 0} \mathrm{m}^{2}\right)$} \\
\hline & & & & \multicolumn{3}{|c|}{$\begin{array}{c}\text { Rainbow/Steelhead } \\
\text { Age/size }\end{array}$} & \multirow[b]{2}{*}{ Total } \\
\hline & & & & 0+ & $1+$ & $\geq 8$ in & \\
\hline \multicolumn{8}{|c|}{ Walla Walla River } \\
\hline WW1 & 31.8 & 5.2 & 165.4 & $1.8^{\mathrm{a}}$ & 0 & 0.6 & 2.4 \\
\hline WW2 & 39.0 & 7.2 & 280.8 & $5.7^{\mathrm{a}}$ & 0 & 0 & 5.7 \\
\hline WW5 & 33.5 & 16.1 & 539.3 & 0 & 0 & 0.2 & 0.2 \\
\hline WW7 & 31.2 & 8.3 & 259.0 & $5.0^{\mathrm{a}}$ & 0 & 0 & 5.0 \\
\hline \multicolumn{8}{|c|}{ Coppei Creek Mainstem } \\
\hline $\mathrm{CC} 1$ & 30.5 & 4.0 & 122.0 & $9.8^{\mathrm{a}}$ & 0 & 0 & 9.8 \\
\hline $\mathrm{CC} 2$ & 28.4 & 3.8 & 107.9 & 2.8 & 0 & 0 & 2.8 \\
\hline $\mathrm{CC} 3$ & 28.4 & 4.4 & 125.0 & 2.4 & 0 & 0 & 2.4 \\
\hline $\mathrm{CC} 4$ & 30.0 & 4.7 & 141.0 & $0.7^{\mathrm{a}}$ & 0 & 0 & 0.7 \\
\hline \multicolumn{8}{|c|}{ North Fork Coppei Creek } \\
\hline NFC1 & 44.8 & 2.0 & 89.6 & 23.4 & 0 & 0 & 23.4 \\
\hline NFC2 & 35.1 & 3.8 & 133.4 & 8.2 & 8.2 & 0 & 16.4 \\
\hline $\mathrm{NFC3}$ & 36.3 & 2.8 & 101.6 & 9.8 & 4.9 & 0 & 14.7 \\
\hline \multicolumn{8}{|c|}{ South Fork Coppei Creek } \\
\hline SFC1 & 49.4 & 2.6 & 128.4 & 8.6 & 13.2 & 0 & 21.8 \\
\hline $\mathrm{SFC} 2$ & 34.2 & 2.7 & 92.3 & 13.0 & $16.2^{\mathrm{a}}$ & 0 & 29.2 \\
\hline $\mathrm{SFC} 3$ & 30.5 & 3.4 & 103.7 & 27.0 & 3.9 & 0 & 30.9 \\
\hline SFC4 & 32.0 & 4.4 & 140.8 & $30.5^{\mathrm{a}}$ & 2.1 & 0 & 32.6 \\
\hline
\end{tabular}

a Calculated using the sum of the passes because of poor reduction between passes, minimum estimates only. 
Table 4. Densities of salmonids from electrofishing sites in the Touchet River and some of its major tributaries, summer and fall1998. Sites are listed in order from upstream to downstream. Sites downstream of Waitsburg City Park (TR15) are omitted as no salmonids were detected in the Touchet River at these locations.

\begin{tabular}{|c|c|c|c|c|c|c|c|c|c|c|c|}
\hline \multirow{3}{*}{$\begin{array}{l}\text { Stream } \\
\text { Reach/ } \\
\text { Site } \\
\text { Name }\end{array}$} & \multirow{3}{*}{$\begin{array}{r}\begin{array}{r}\text { Site } \\
\text { Length } \\
(\mathrm{m})\end{array} \\
\end{array}$} & \multirow{3}{*}{$\begin{array}{r}\text { Mean } \\
\text { Width } \\
(\mathrm{m}) \\
\end{array}$} & \multirow[b]{3}{*}{$\begin{array}{r}\text { Area } \\
\left(\mathrm{m}^{2}\right)\end{array}$} & \multicolumn{8}{|c|}{ Densities (\#/100 m²) } \\
\hline & & & & \multicolumn{3}{|c|}{$\begin{array}{c}\text { Rainbow/Steelhead } \\
\text { Age/size }\end{array}$} & \multirow[b]{2}{*}{ Total } & \multirow[b]{2}{*}{$\begin{array}{l}\text { Other } \\
\text { Species }\end{array}$} & \multicolumn{3}{|c|}{ Age/size } \\
\hline & & & & 0+ & $1+$ & $\geq 8$ in & & & $\mathbf{0 +}$ & $1+$ & $\geq 8$ in \\
\hline \multicolumn{12}{|c|}{ North Fork Touchet } \\
\hline NFT1 & 36.7 & 4.0 & 146.8 & $0.7^{\mathrm{b}}$ & 5.3 & 0 & 6.0 & BT & $13.6^{\mathrm{b}}$ & $7.5^{\mathrm{b}}$ & 0 \\
\hline NFT2 & 32.3 & 4.3 & 138.9 & 7.2 & 13.7 & 0 & 20.9 & & & & \\
\hline NFT3 & 27.1 & 7.0 & 189.7 & 24.2 & 6.3 & 0 & 30.5 & & & & \\
\hline NFT4 & 30.0 & 8.1 & 243.0 & $9.9^{\mathrm{b}}$ & $8.2^{\mathrm{b}}$ & 0 & 18.1 & & & & \\
\hline \multirow[t]{2}{*}{ NFT5 } & 32.6 & 10.6 & 345.6 & $15.3^{\mathrm{b}}$ & 0 & 0 & 15.3 & BRT & $1.7^{\mathrm{b}}$ & 0 & 0 \\
\hline & & & & & & & & WF & $0.6^{\mathrm{b}}$ & 0 & 0 \\
\hline \multicolumn{12}{|c|}{ Wolf Fork } \\
\hline WFT1 & 30.0 & 5.1 & 153.0 & $2.0^{\mathrm{b}}$ & 7.2 & 0 & 9.2 & BT & $7.8^{\mathrm{b}}$ & 5.2 & 0 \\
\hline WFT2 & 30.5 & 8.1 & 247.0 & $33.6^{\mathrm{b}}$ & $17.4^{\mathrm{b}}$ & 0 & 51.0 & & & & \\
\hline WFT3 & 33.0 & 8.0 & 264.0 & 28.4 & $11.0^{\mathrm{b}}$ & 0 & 39.4 & BRT & $0.4^{\mathrm{b}}$ & 0 & 0 \\
\hline \multicolumn{12}{|c|}{ Robinson Creek } \\
\hline $\mathrm{RC} 1$ & 28.4 & 3.6 & 102.2 & $1.0^{\mathrm{b}}$ & 32.3 & 0 & 33.3 & & $0.8^{\mathrm{b}}$ & 0 & 0 \\
\hline $\mathrm{RC} 2$ & 30.0 & 4.3 & 129.0 & 5.4 & 31.0 & $0.8^{\mathrm{b}}$ & 37.2 & BRT & & & \\
\hline \multicolumn{12}{|c|}{ South Fork Touchet } \\
\hline SFT1 & 48.3 & 6.8 & 328.4 & 16.1 & 15.8 & $0.3^{\mathrm{b}}$ & 32.2 & & & & \\
\hline SFT2 & 31.0 & 10.8 & 334.8 & 18.5 & 23.3 & $1.5^{\mathrm{b}}$ & 43.3 & & & & \\
\hline SFT3 & 37.0 & 7.5 & 277.5 & $12.2^{\mathrm{b}}$ & $5.0^{\mathrm{b}}$ & 0 & 17.2 & & & & \\
\hline \multicolumn{12}{|c|}{ Touchet River from S. Fork to Rose Gulch } \\
\hline \multirow[t]{2}{*}{ TR2 } & 65.9 & 8.4 & 553.6 & $22.8^{\mathrm{b}}$ & 2.5 & $0.7^{\mathrm{b}}$ & 26.0 & BRT & 1.3 & $0.2^{\mathrm{b}}$ & 0 \\
\hline & & & & & & & & WF & 0.7 & 0 & 0 \\
\hline \multirow[t]{2}{*}{ TR6 } & 26.8 & 9.3 & 249.2 & $11.1^{\mathrm{b}}$ & 3.6 & 0.4 & 14.7 & CHIN & $0.4^{\mathrm{b}}$ & 0 & 0 \\
\hline & & & & & & & & BRT & $0.8^{\mathrm{b}}$ & 0 & $2.8^{\mathrm{b}}$ \\
\hline \multirow[t]{3}{*}{ TR7 } & 30.5 & 12.9 & 393.4 & $2.3^{\mathrm{b}}$ & $2.0 \mathrm{~b}$ & $0.2^{\mathrm{b}}$ & 4.5 & CHIN & $0.2^{\mathrm{b}}$ & 0 & 0 \\
\hline & & & & & & & & BRT & $0.2^{\mathrm{b}}$ & 0 & 0 \\
\hline & & & & & & & & WF & $0.2^{\mathrm{b}}$ & 0 & 0 \\
\hline TR8 & 29.5 & 17.5 & 516.2 & $4.1^{\mathrm{b}}$ & 0 & 0 & 4.1 & BRT & $0.8^{\mathrm{b}}$ & 0 & $0.2^{\mathrm{b}}$ \\
\hline TR12 & 31.7 & 10.7 & 339.2 & $9.7^{\mathrm{b}}$ & 0 & 0 & 9.7 & BRT & $0.3^{\mathrm{b}}$ & 0 & 0 \\
\hline \multicolumn{12}{|c|}{ Touchet River from Rose Gulch to Coppei Cr. } \\
\hline TR13 & 36.0 & 14.1 & 507.6 & 2.0 & 0 & 0 & 2.0 & BRT & $0.2^{\mathrm{b}}$ & 0 & 0 \\
\hline TR14 & 31.3 & 8.6 & 269.2 & $10.3^{\mathrm{b}}$ & 0 & 0 & 10.3 & BRT & $1.1^{\mathrm{b}}$ & 0 & 0 \\
\hline TR15 & 33.0 & 9.7 & 320.1 & 4.1 & 0 & 0 & 4.1 & & & & \\
\hline
\end{tabular}

a $\quad \mathrm{BT}=$ bull trout; $\mathrm{BRT}=$ brown trout; $\mathrm{WF}=$ whitefish, $\mathrm{CHIN}=$ chinook.

b Calculated using the sum because of poor reduction between passes, minimum estimate only. 
Table 5. Densities of salmonids from snorkeling sites on the Touchet and Walla Walla rivers, summer and fall 1998. Sites are listed from upstream site to downstream. No salmonids were detected at snorkeling sites downstream of the Waitsburg City Park (site TR15) on the Touchet River, and Last Chance Road (site WW6) on the Walla Walla River.

\begin{tabular}{|c|c|c|c|c|c|c|c|c|c|c|c|}
\hline \multirow{3}{*}{$\begin{array}{l}\text { Stream } \\
\text { Reach/ } \\
\text { Site } \\
\text { Name }\end{array}$} & \multirow{3}{*}{$\begin{array}{r}\text { Site } \\
\text { Length } \\
(\mathrm{m})\end{array}$} & \multirow{3}{*}{$\begin{array}{r}\text { Mean } \\
\text { Width } \\
(m)\end{array}$} & \multirow[b]{3}{*}{$\begin{array}{r}\text { Area } \\
\left(\mathbf{m}^{2}\right)\end{array}$} & \multicolumn{8}{|c|}{ Densities $\left(\# / 100 \mathrm{~m}^{2}\right)$} \\
\hline & & & & \multicolumn{3}{|c|}{$\begin{array}{c}\text { Rainbow/Steelhead } \\
\text { Age/size }\end{array}$} & \multirow[b]{2}{*}{ Total } & \multirow[b]{2}{*}{$\begin{array}{l}\text { Other } \\
\text { Species a }\end{array}$} & \multicolumn{3}{|c|}{ Age/size } \\
\hline & & & & 0+ & $1+$ & $\geq 8$ in & & & $0+$ & $1+$ & $\geq 8$ in \\
\hline \multicolumn{12}{|l|}{ Touchet } \\
\hline TR1 & 131.2 & 10.1 & 1323.8 & 6.0 & 5.7 & 0.8 & 12.5 & $\begin{array}{l}\text { BRT } \\
\text { WF } \\
\text { UNK }\end{array}$ & $\begin{array}{r}0.1 \\
0 \\
0.6\end{array}$ & $\begin{array}{l}0.1 \\
0.1 \\
0.2\end{array}$ & $\begin{array}{r}0.1 \\
0 \\
0.5\end{array}$ \\
\hline TR3 & 152.5 & 10.2 & 1558.4 & 3.7 & 2.8 & 7.1 & 13.6 & $\begin{array}{l}\text { BRT } \\
\text { WF } \\
\text { UNK }\end{array}$ & $\begin{array}{l}0.1 \\
0.4 \\
0.4\end{array}$ & $\begin{array}{l}0.2 \\
0.4 \\
0.3\end{array}$ & $\begin{array}{r}0.3 \\
0 \\
0.3\end{array}$ \\
\hline TR7 & 135.6 & 4.0 & 539.0 & 7.6 & 3.3 & 0 & 10.9 & WF & 0.5 & 0 & 0 \\
\hline TR9 & 91.5 & 14.7 & 1345.0 & 13.7 & 7.0 & 0.3 & 21.0 & $\begin{array}{l}\text { BRT } \\
\text { WF }\end{array}$ & $\begin{array}{l}0.4 \\
0.1\end{array}$ & $\begin{array}{l}0.2 \\
0.5\end{array}$ & $\begin{array}{r}0 \\
0.2\end{array}$ \\
\hline TR10 & 91.5 & 16.3 & 1491.0 & 3.0 & 3.6 & 0 & 6.6 & $\begin{array}{l}\text { BRT } \\
\text { WF }\end{array}$ & $\begin{array}{l}0.2 \\
0.5\end{array}$ & $\begin{array}{l}0 \\
0\end{array}$ & $\begin{array}{l}0 \\
0\end{array}$ \\
\hline $\begin{array}{l}\text { TR11 } \\
\text { TR13 } \\
\text { TR14 } \\
\text { TR15 }\end{array}$ & $\begin{array}{r}122.0 \\
92.7 \\
91.5 \\
96.1\end{array}$ & $\begin{array}{l}10.0 \\
14.8 \\
12.0 \\
10.7\end{array}$ & $\begin{array}{l}1218.8 \\
1372.1 \\
1098.5 \\
1025.7\end{array}$ & $\begin{array}{r}1.5 \\
1.0 \\
0 \\
0.2\end{array}$ & $\begin{array}{r}3.2 \\
0.2 \\
0 \\
0\end{array}$ & $\begin{array}{l}0 \\
0 \\
0 \\
0\end{array}$ & $\begin{array}{l}4.7 \\
1.2 \\
0.0 \\
0.2\end{array}$ & BRT & 0 & 0.2 & 0.1 \\
\hline \multicolumn{12}{|c|}{ Walla Walla } \\
\hline $\begin{array}{l}\text { WW2 } \\
\text { WW4 } \\
\text { WW5 } \\
\text { WW6 }\end{array}$ & $\begin{array}{l}122.0 \\
125.0 \\
122.0 \\
122.0\end{array}$ & $\begin{array}{r}8.4 \\
8.5 \\
13.4 \\
11.9\end{array}$ & $\begin{array}{l}1026.4 \\
1059.6 \\
1631.3 \\
1450.0\end{array}$ & $\begin{array}{r}0.1 \\
0 \\
0.1 \\
0.3\end{array}$ & $\begin{array}{l}0.6 \\
0.1 \\
0.1 \\
0.1\end{array}$ & $\begin{array}{l}0 \\
0 \\
0 \\
0\end{array}$ & $\begin{array}{l}0.7 \\
0.1 \\
0.2 \\
0.4\end{array}$ & & & & \\
\hline
\end{tabular}

a $\quad$ BRT=brown trout; $\mathrm{WF}=$ whitefish; $\mathrm{UNK}=$ unknown salmonid species 
Table 6. Biomass of salmonids from electrofishing sites in the Walla Walla River, and Coppei Creek, a tributary of the Touchet River, summer and fall 1998. Sites with salmonids are listed in upstream to downstream order. Unlisted sites on the Walla Walla River are omitted as no salmonids were found at these locations.

\begin{tabular}{|c|c|c|c|c|c|c|c|}
\hline \multirow{3}{*}{$\begin{array}{l}\text { Stream } \\
\text { Reach/ } \\
\text { Site Name }\end{array}$} & \multirow{3}{*}{$\begin{array}{r}\text { Site } \\
\text { Length (m) }\end{array}$} & \multirow{3}{*}{$\begin{array}{r}\text { Mean } \\
\text { Width }(m)\end{array}$} & \multirow{3}{*}{ Area $\left(m^{2}\right)$} & \multicolumn{4}{|c|}{ Biomass $\left(\operatorname{grams} / \mathbf{1 0 0} \mathrm{m}^{2}\right)^{\mathrm{a}}$} \\
\hline & & & & \multicolumn{3}{|c|}{$\begin{array}{c}\text { Rainbow/Steelhead } \\
\text { Age/size }\end{array}$} & \multirow[b]{2}{*}{ Total } \\
\hline & & & & 0+ & $1+$ & $\geq 8$ in & \\
\hline \multicolumn{8}{|c|}{ Walla Walla River } \\
\hline $\begin{array}{l}\text { WW1 } \\
\text { WW2 } \\
\text { WW5 } \\
\text { WW7 }\end{array}$ & $\begin{array}{l}31.8 \\
39.0 \\
33.5 \\
31.2\end{array}$ & $\begin{array}{r}5.2 \\
7.2 \\
16.1 \\
8.3\end{array}$ & $\begin{array}{l}165.4 \\
280.8 \\
539.3 \\
259.0\end{array}$ & $\begin{array}{r}8.2 \\
15.4 \\
0 \\
29.3\end{array}$ & $\begin{array}{l}0 \\
0 \\
0 \\
0\end{array}$ & $\begin{array}{r}8.1 \\
0 \\
144.0^{\mathrm{b}} \\
0\end{array}$ & $\begin{array}{r}16.3 \\
15.4 \\
144.0 \\
29.3\end{array}$ \\
\hline \multicolumn{8}{|c|}{ Coppei Creek Mainstem } \\
\hline $\begin{array}{l}\mathrm{CC} 1 \\
\mathrm{CC} 2 \\
\mathrm{CC} 3 \\
\mathrm{CC} 4\end{array}$ & $\begin{array}{l}30.5 \\
28.4 \\
28.4 \\
30.0\end{array}$ & $\begin{array}{l}4.0 \\
3.8 \\
4.4 \\
4.7\end{array}$ & $\begin{array}{l}122.0 \\
107.9 \\
125.0 \\
141.0\end{array}$ & $\begin{array}{r}46.7 \\
17.5 \\
12.3 \\
1.6\end{array}$ & $\begin{array}{l}0 \\
0 \\
0 \\
0\end{array}$ & $\begin{array}{l}0 \\
0 \\
0 \\
0\end{array}$ & $\begin{array}{r}46.7 \\
17.5 \\
12.3 \\
1.6\end{array}$ \\
\hline \multicolumn{8}{|c|}{ North Fork Coppei Creek } \\
\hline $\begin{array}{l}\text { NFC1 } \\
\text { NFC2 } \\
\text { NFC3 }\end{array}$ & $\begin{array}{l}44.8 \\
35.1 \\
36.3\end{array}$ & $\begin{array}{l}2.0 \\
3.8 \\
2.8\end{array}$ & $\begin{array}{r}89.6 \\
133.4 \\
101.6\end{array}$ & $\begin{array}{r}0 \\
27.7 \\
30.7\end{array}$ & $\begin{array}{l}440.6 \\
157.6 \\
152.0\end{array}$ & $\begin{array}{l}0 \\
0 \\
0\end{array}$ & $\begin{array}{l}440.6 \\
185.3 \\
182.7\end{array}$ \\
\hline \multicolumn{8}{|c|}{ South Fork Coppei Creek } \\
\hline $\begin{array}{l}\text { SFC1 } \\
\text { SFC2 } \\
\text { SFC3 } \\
\text { SFC4 }\end{array}$ & $\begin{array}{l}49.4 \\
34.2 \\
30.5 \\
32.0\end{array}$ & $\begin{array}{l}2.6 \\
2.7 \\
3.4 \\
4.4\end{array}$ & $\begin{array}{r}128.4 \\
92.3 \\
103.7 \\
140.8\end{array}$ & $\begin{array}{r}32.7^{\mathrm{c}} \\
43.6^{\mathrm{c}} \\
89.9^{\mathrm{c}} \\
98.5\end{array}$ & $\begin{array}{r}353.8^{\mathrm{c}} \\
291.6 \\
111.2^{\mathrm{c}} \\
67.1\end{array}$ & $\begin{array}{l}0 \\
0 \\
0 \\
0\end{array}$ & $\begin{array}{l}386.5 \\
335.2 \\
201.1 \\
165.6\end{array}$ \\
\hline
\end{tabular}

a Used density estimates from tables 3 and 4.

b Hatchery origin.

c Includes fish with estimated weights based on other weights measured within the reach. 
Table 7. Biomass of salmonids from electrofishing sites in the Touchet River, summer and fall 1998. Sites with salmonids are listed in upstream to downstream order.

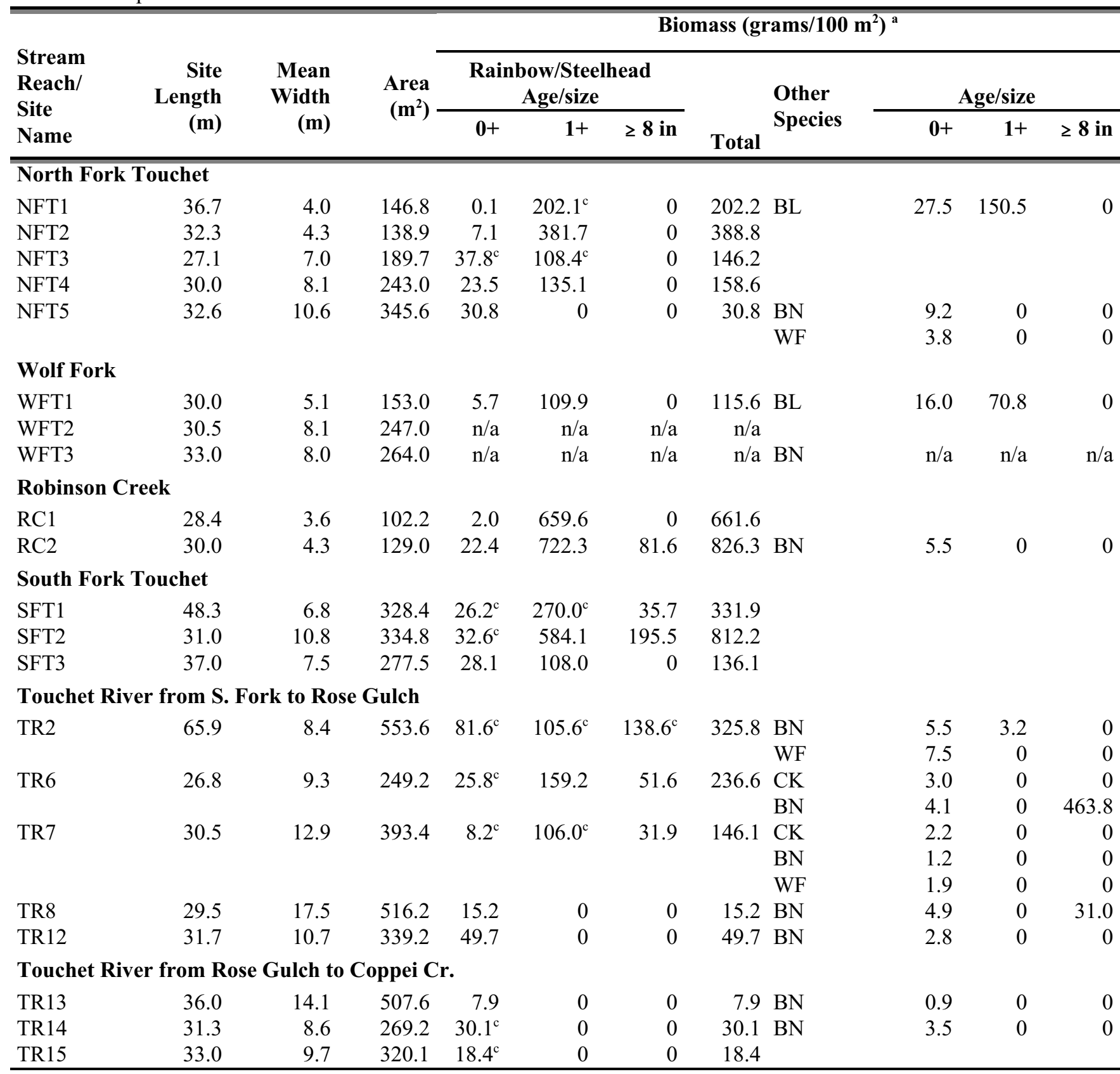

Used density estimates from tables 3 and 4.

$\mathrm{BL}=$ bull trout; $\mathrm{BN}=$ brown trout; $\mathrm{WF}=$ whitefish; $\mathrm{CK}=$ chinook.

Includes fish with estimated weights based on other weights measured within the reach.

Hatchery origin. 
Two age classes $(0+$ and $1+)$ of unrecognizable trout were captured at two sites on the North Fork Touchet. These trout were muddy brown in color with small black spots and no parr marks. They were captured with brightly colored rainbow/steelhead trout with large parr marks. Two specimens were retained for later identification and DNA analysis. Results of DNA analysis are pending.

Salmonid abundance and distribution were closely tied to instream habitat conditions in the Walla Walla Basin. An important habitat variable associated with the presence or absence of salmonid species appeared to be temperature (Table 8). August was chosen as a reference month for comparison because most electrofishing and snorkeling sites were sampled during August, or during the week preceding or following August. Thus, observed salmonid densities were most directly tied with August instream temperatures.

Table 8. Monthly temperature means for instream monitoring sites and mean salmonid density averaged from sites at, immediately above, and immediately below the monitor.

\begin{tabular}{lrrrr}
\hline & \multicolumn{3}{c}{ Mean Temperature $\left({ }^{\circ} \mathbf{F}\right)$} \\
Monthly Location & Density \#/100 ${ }^{2}$ & July & Aug & Sept \\
\hline Touchet River & & & & 60.6 \\
Dayton & 23.4 & 67.5 & 65.6 & 65.7 \\
State Park & 11.1 & 74.2 & 69.1 & 64.3 \\
Waitsburg & 5.2 & 74.3 & 70.8 & 66.8 \\
Lamar & 0 & 78.0 & 73.9 & 67.3 \\
Simms Road & 0 & 79.2 & 74.4 & 67.6 \\
Touchet Gunclub & 0 & 79.4 & & \\
Walla Walla R. & & & & 66.2 \\
Beet Rd. & 0.2 & 72.0 & 69.0 & 64.2 \\
Swegle Rd. & 0.5 & 73.4 & 71.1 & 69.5 \\
McDonald Rd & 0 & 76.8 & 74.3 & \\
\hline
\end{tabular}

There was also an association between river mile (distance upstream from the mouth) and salmonid density (no. of individuals per $100 \mathrm{~m}^{2}$ ). Data from electrofishing showed that salmonids increased with increasing river mile on the mainstem Touchet River (Figure 5). This relation is probably due mainly to increasing river temperatures downstream.

The relationship was much weaker for the Walla Walla River (Figure 6). Patchy concentrations of rainbow/steelhead trout, in areas where ground water recharge increased flows or habitat conditions were more favorable, lead to an uneven distribution in the upper Walla Walla River within Washington. Both rivers showed a bi-modal pattern, where salmonid numbers dropped sharply or disappeared at specific points. These points occur in the area of Waitsburg on the Touchet River; and McDonald Road on the Walla Walla River (Figure 6).

There were insufficient data points to reliably compare salmonid density vs river mile on individual forks of the Touchet River, and mainstem and forks of Coppei Creek. 


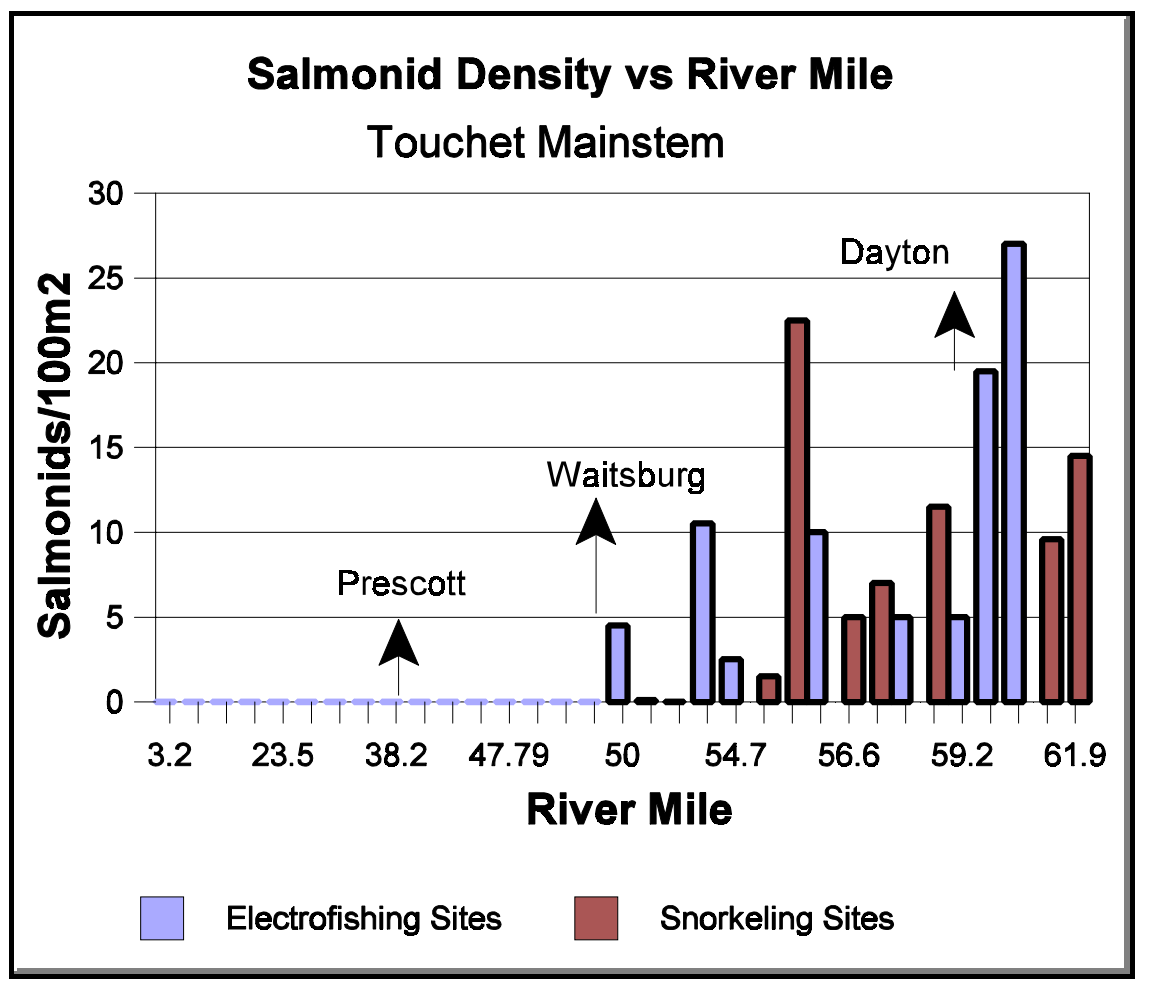

Figure 5. Total salmonid densities on the Touchet River in relation to river mile. River mile is the distance from the river's mouth (landmarks are named at arrows).

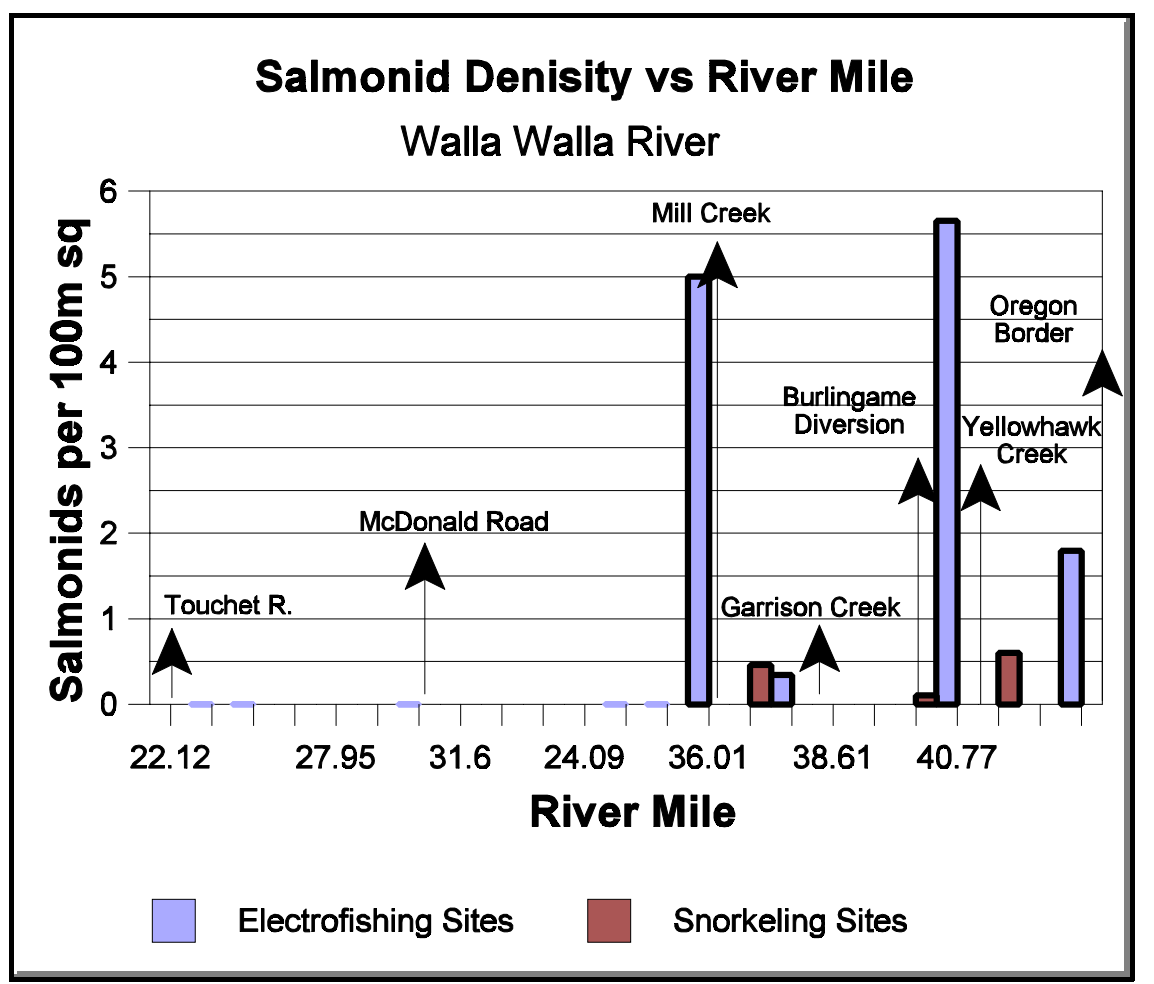

Figure 6. Total salmonid densities on the Walla Walla River, in relation to river mile. River mile is the distance upstream from the river's mouth (landmarks are named at arrows). 


\section{Salmonid Age and Physical Demographics}

Densities of rainbow/steelhead trout were variable from site to site and ranged from 0.1 to 51.0 individuals per $100 \mathrm{~m}^{2}$ at occupied sites (Tables 3 to 5 ). Sub-yearling juvenile fish (0+) were the most abundant age-class at most sites. On the Touchet River, "legal-sized" rainbow/steelhead were not detected below Lewis and Clark Trail State Park (Table 4). Bull trout sub-yearlings predominated at the two sites where the species was detected. Brown trout age distribution appeared to be bi-modal, with very young or mature fish predominating. The two chinook salmon collected near Dayton were sub-yearlings.

\section{Other Fish Species Abundance and Distribution}

Fish, other than salmonids, were assessed qualitatively. Their presence/absence and estimated abundance were recorded during electrofishing and snorkeling surveys. Presence/absence data should be viewed with caution, because the number of sites sampled $(n)$ in a given reach were limited.

Distribution of sculpins (family Cottidae) was of particular interest, due to the paucity of information on this group, and the recent listing by the Washington Department of Fish and Wildlife (WDFW), of the margined sculpin as a "Sensitive" species. The decision to list the margined sculpin was based on two factors: (1) the margined sculpin is an endemic species with a small distribution in Washington State that is limited to the Tucannon and Walla Walla watersheds; and (2) these watersheds have significant habitat degradation and population trends for the species are unknown, due to a lack of historical data and limited current research (Mongillo and Hallock 1998). Because of its limited distribution and possible habitat specialization, the margined sculpin may be at increased risk for extinction (Hedricks 1996, Mongillo and Hallock 1998).

This study found interesting patterns in the distribution of margined sculpins and the closely related piute sculpin (Table 8). Generally, they were sympatric and found in relatively equal abundance at most sites. Both species appeared to be sensitive to excessive stream temperatures and turbidity, and were rare or absent in the lower reaches of the Touchet and Walla Walla rivers.

Torrent sculpins had a patchy distribution and were in low numbers where they were found (Table 8). The species is known to prefer relatively wide streams with brisk water flow and a coarse gravel substrate (Wydoski and Whitney 1979). The majority of the reaches in the study area did not meet these criteria.

\section{Stream Temperatures}

The summer of 1998 was hotter than normal in the study area. Mean maximum temperatures at the Whitman Mission were 77, 92, 89, $82^{\circ} \mathrm{F}$, for the months of June, July, August and September, respectively. In comparison, the 1986-1996 averages for the specified months are: $77,82,80,73^{\circ} \mathrm{F}$, respectively (National Oceanographic and Atmospheric Administration [NOAA] data).

Stream temperatures reflected the hot and arid climatic regime. During mid-summer (July to early August), when the photo period is long and evening cooling brief, peak daily temperatures at instream 
monitoring sites routinely exceeded lethal limits for salmon (75-84 $\mathrm{F}$, Bjornn and Reiser 1991): for the mainstem Touchet River, Yellowhawk Creek, and the Walla Walla River (Appendix B). Lower Coppei Creek registered lethal temperatures for a two-week period in early August. However, the monitor was not installed until August 4; lethal instream temperatures were likely to be present during the preceding month. Peak temperatures on monitors upstream of Dayton did not reach lethal levels.

During the same period, at the same sites, mean and mode daily temperatures, which reflect conditions salmon have to endure for long periods, were routinely high enough (above $68^{\circ} \mathrm{F}$ ) to inhibit migration of adults and young, and to sharply reduce survival of embryos and fry (Bjornn and Reiser 1991). Sites on the mid and lower Touchet and lower Walla Walla had repetitive daily mean and mode temperatures that exceeded lethal levels $\left(>75^{\circ} \mathrm{F}\right)$ during summer months (Figures 7 and 8 , Appendix B) but not in the tributaries (Figure 9). No salmonids were detected in electrofishing or snorkeling surveys in these areas.

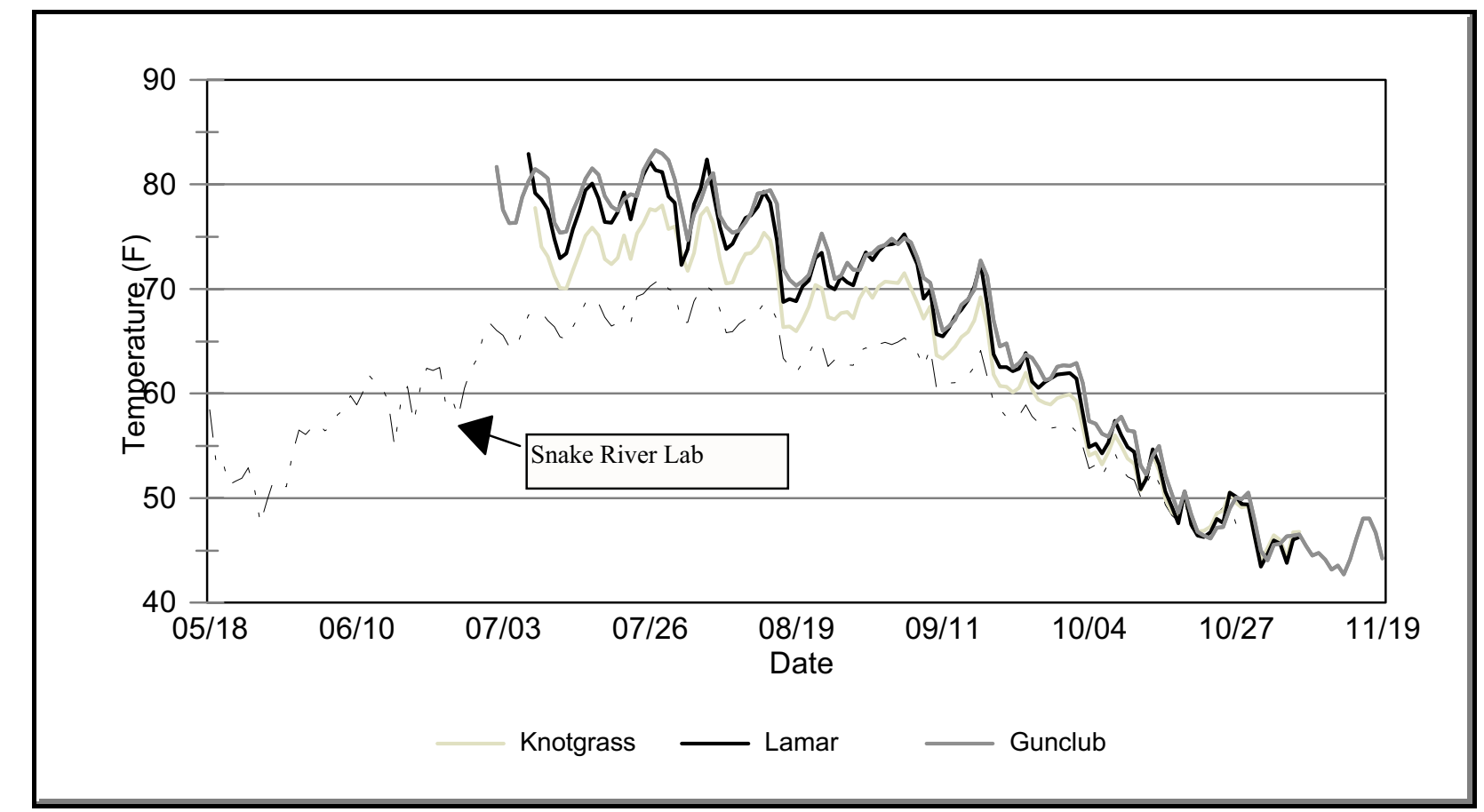

Figure 7. Daily mean temperature at four instream monitor sites on the Touchet River. For clarity, sites at Lewis and Clark Trail State Park and Simms Road are omitted. 


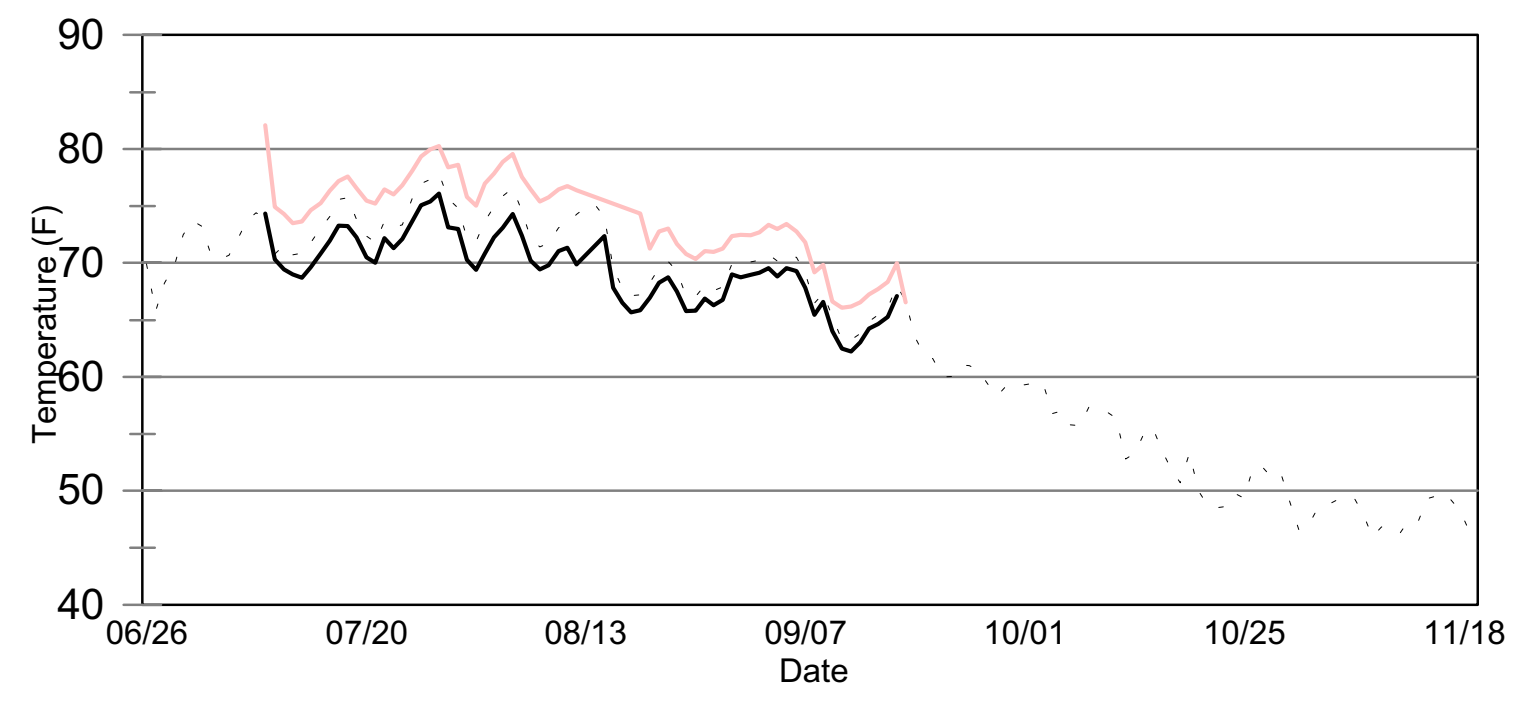

Beet Rd. _ _ S Swegle Rd. $\quad$ McDonald Rd.

Figure 8. Daily mean temperatures at instream monitor sites on the Walla Walla River mainstem, 1998.

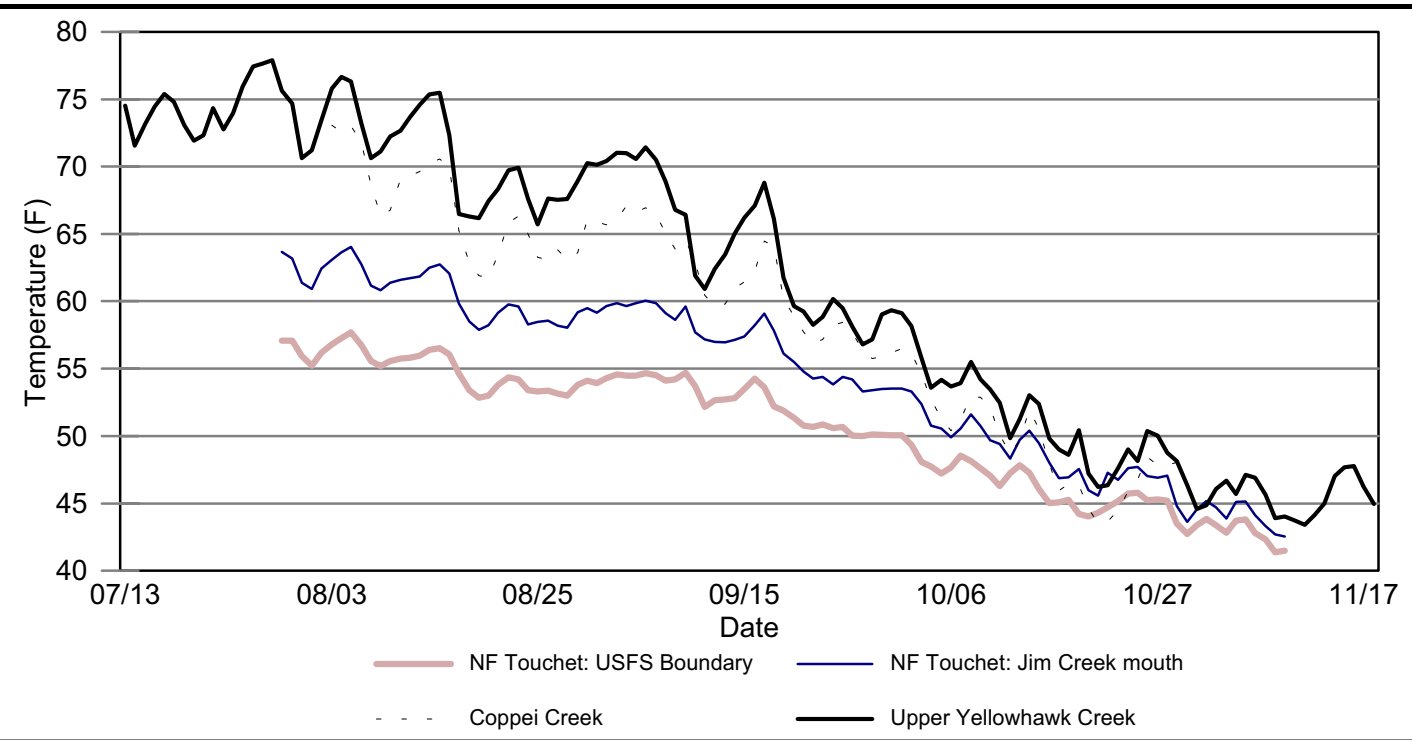

Figure 9. Daily mean temperatures on tributary streams. For graph clarity, the lower Yellowhawk site is omitted. 


\section{Stream Flows}

A general pattern of gradually declining stream flow from mid-July to mid-September, followed by fairly rapidly increasing flows, predominated in the greater Walla Walla Basin (Figure 10). However, sites in proximity to major irrigation facilities exhibited a more erratic stream flow pattern. Flows were likely influenced by an inter-relationship of climatic events and irrigation withdrawals.

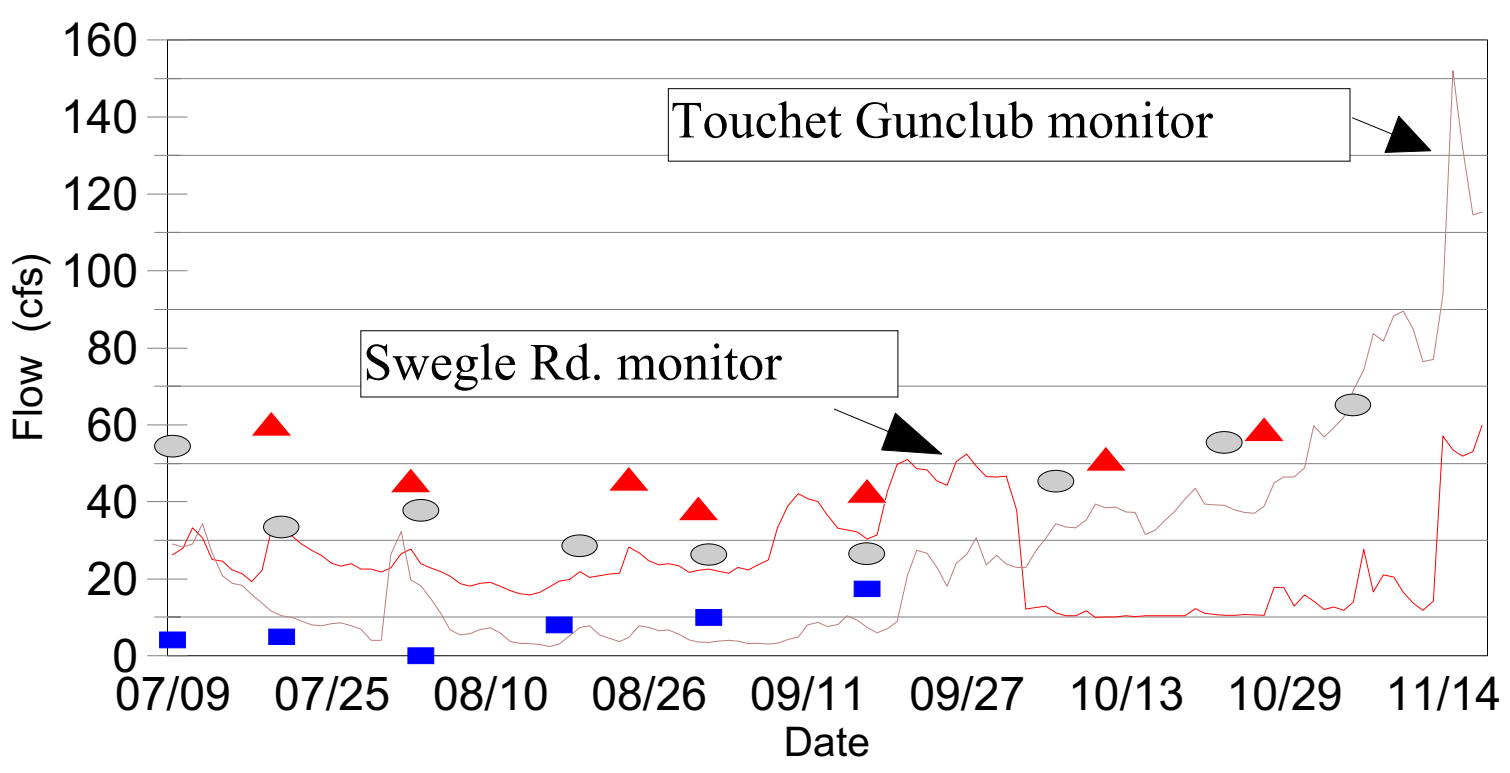

- McDonald Road Manual Flow Site

Simms Road Manual Flow Site

- Dayton Manual Flow Site

Figure 10. Instream flows (in cubic feet per second) at selected sites in the Walla Walla Basin, 1998. Note: The Dayton, Simms Road and Touchet Gunclub sites are on the Touchet River in descending order. The Swegle Road and McDonald Road sites are in descending order on the Walla Walla River. The Simms Road site is approximately nine miles above Hofer Dam, and the Touchet Gunclub site is about one mile below the dam.

One climatic event appeared to a have an ephemeral influence on flows in the Touchet River system. On the evening of July $30^{\text {th }}$, a storm system passed through the northern study area, depositing over 1.8 inches of rain in less than two hours. This apparently resulted in a transient increase in flows and decrease in stream temperatures that lasted less than a week. During the same period, field observers noted a marked increase in river turbidity on the Touchet River from Waitsburg downstream. Substantial erosion and gullying of plowed fields in the Waitsburg and Prescott areas, necessitating emergency road clearing at several locations, was also noted. A Waitsburg resident reported observing 
numerous dead fish on the river bank following the storm. This climatic event is evidenced by a trough on temperature graphs for mid and lower Touchet River sites at the end of July and beginning of August (Appendix B). It is also evidenced by a sharp peak in flows measured at the Touchet Gunclub site (Appendix B).

Irrigation withdrawals included pumps and "push-up" dams with gravity diversions on private lands, and irrigation district diversion canals at Dayton and Hofer Dam on the Touchet River, and Burlingame Diversion and Nursery Bridge in Oregon, on the Walla Walla River.

Reduced flows downstream of major irrigation facilities operating in peak mode were observed during the field season. Specific observations included: (1) complete dewatering of the Walla Walla River channel for about one-half mile below the Oregon border, observed from the air; (2) sharp flow reduction below Burlingame Diversion between mid-September and mid-October, as recorded by manual and instream flow monitoring at Beet, Swegle and McDonald Roads (Appendix B); and, (3) an abrupt reduction of flow from $20-40$ cfs to less than $10 \mathrm{cfs}$ from mid-July through mid-September below Hofer Dam on the Touchet River, as recorded by the instream flow monitor at Touchet Gunclub (Figure 10, Appendix B).

\section{Additional Parameter Assessments}

\section{Limiting Factor Identification}

A number of barriers and impediments to salmonid passage or rearing were identified during the field season. A portion of these barriers were physical (e.g. structures or dewatered streambeds) that physically blocked salmonid movement. Physical barriers included:

- a partially-to-completely dewatered zone near the Oregon border on the Walla Walla River that extended from below Nursery Dam to approximately one mile downstream of the state border;

- Mill Creek dewatered from the Division Dam near eastern Walla Walla city limits to downstream of College Place;

- $\quad$ no fish passage possible through Burlingame Diversion on the Walla Walla River during construction activities;

- dewatered streambed and instream construction activities at McDonald Rd. on the Walla Walla River observed in early October;

- $\quad$ streambed dewatered to a series of pools on the Walla Walla, just upstream of the Touchet River confluence, observed in August and October;

- wood and plastic height additions to Hofer Dam on the lower Touchet River were a potential barrier to both upstream and downstream fish passage during much of the summer and fall.

Physiological barriers and impediments to salmonid passage and rearing were extensive in terms of stream miles affected. The primary physiological factor examined in this study was temperature. Flows were also examined, but minimum adequate flows for salmonids, which are definitively identified by 
Instream Flow Incremental Methodology (IFIM), were not determined in this first year of the study. Turbidity, sedimentation, lack of cover, and other habitat factors, also present challenges to migrating and breeding and rearing salmonids, but these factors were not routinely measured in the first year of study.

Considering temperature alone, several reaches of the Walla and Touchet Rivers were identified as presenting significant physiological barriers to salmonid passage and rearing during the summer months. Consideration criteria included: (1) mean temperatures greater than $75^{\circ} \mathrm{F}$ for extended periods at sites with continuous instream temperature monitoring; (2) spot daytime temperatures exceeding $78^{\circ} \mathrm{F}$ at manual measurement sites; and, (3) absence of salmonid fishes at electrofishing and snorkeling sites within the reach. Extended periods were defined as four sequential days or ten days out of a calendar month. If criteria " 1 " or " 2 " were met, but salmonids were present, then the reach was identified as "sub-optimal". All reaches and forks of the Touchet River above Dayton maintained cool temperatures, in a range favorable to most salmonids, throughout the summer. Table 9 lists reaches with evidence of physiological barriers to salmonids due to high temperatures. 
Table 9. Non-salmonid species average abundance in specified reaches. Key: absent $=0$; rare $=+$; uncommon $=++$; common $=+++$; abundant $=++++$; NA - data not available. See Table 2 for abundance criteria.

\begin{tabular}{|c|c|c|c|c|c|c|c|c|c|c|c|c|}
\hline & \multicolumn{12}{|c|}{ Reach } \\
\hline & \multicolumn{10}{|c|}{ Touchet Basin } & \multicolumn{2}{|c|}{ Walla Walla Basin } \\
\hline Species & 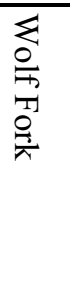 & 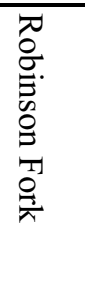 & 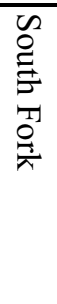 & 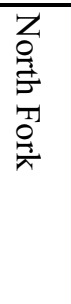 & 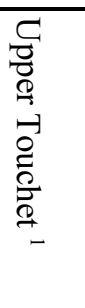 & 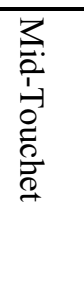 & 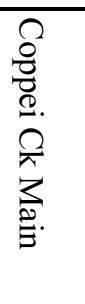 & $\begin{array}{l}\hat{\Omega} \\
\frac{8}{8} \\
\frac{0}{a} . \\
2 \\
\hat{\pi} \\
01\end{array}$ & 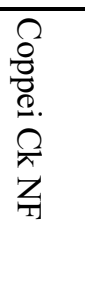 & 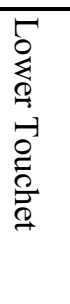 & 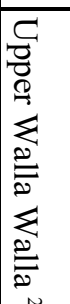 & 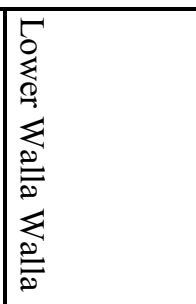 \\
\hline $\begin{array}{l}\text { Petromyzontide } \\
\text { Lamprey larvae }\end{array}$ & + & 0 & NA & + & + & 0 & + & + & + & 0 & + & + \\
\hline $\begin{array}{l}\text { Cyprinidae } \\
\text { Speckled dace } \\
\text { Rhinichtys osculus }\end{array}$ & NA & +++ & NA & 0 & ++++ & ++++ & +++ & +++ & +++ & +++ & +++ & +++ \\
\hline $\begin{array}{l}\text { Chiselmouth } \\
\text { Acroheilus alutaceus }\end{array}$ & NA & 0 & NA & 0 & 0 & + & 0 & 0 & 0 & +++ & ++ & + \\
\hline $\begin{array}{l}\text { Redside shiner } \\
\text { Richardsonius balteatus }\end{array}$ & $\mathrm{NA}$ & 0 & NA & 0 & +++ & +++ & +++ & 0 & 0 & ++ & ++ & +++ \\
\hline $\begin{array}{l}\text { Northern pikeminnow } \\
\text { Ptychocheilus } \\
\text { oregonesis }\end{array}$ & NA & 0 & NA & 0 & ++ & ++ & + & 0 & 0 & ++ & ++ & + \\
\hline $\begin{array}{l}\text { Catostomidae } \\
\text { Suckers }^{3} \\
\text { Catostomus sp. }\end{array}$ & $\mathrm{NA}$ & 0 & NA & 0 & + & + & ++ & + & 0 & +++ & ++ & + \\
\hline $\begin{array}{l}\text { Warmwater fish } \\
\text { Tadpole madtom } \\
\text { Noturus gyrinus } \\
\end{array}$ & $\mathrm{NA}$ & 0 & NA & 0 & 0 & 0 & 0 & 0 & 0 & 0 & 0 & + \\
\hline $\begin{array}{l}\text { Channel catfish } \\
\text { Ictalurus punctatus }\end{array}$ & $\mathrm{NA}$ & 0 & NA & 0 & 0 & 0 & 0 & 0 & 0 & 0 & 0 & + \\
\hline $\begin{array}{l}\text { Yellow bullhead } \\
\text { Ictaluris natalis }\end{array}$ & $\mathrm{NA}$ & 0 & NA & 0 & 0 & 0 & 0 & 0 & 0 & 0 & 0 & + \\
\hline $\begin{array}{l}\text { Smallmouth bass } \\
\text { Micropterus dolomieui }\end{array}$ & $\mathrm{NA}$ & 0 & NA & 0 & 0 & + & 0 & 0 & 0 & ++ & 0 & + \\
\hline $\begin{array}{l}\text { Bluegill } \\
\text { Lepomis macrochirus }\end{array}$ & $\mathrm{NA}$ & 0 & NA & 0 & 0 & 0 & 0 & 0 & 0 & 0 & 0 & + \\
\hline $\begin{array}{l}\text { Cottidae } \\
\text { Piute sculpin } \\
\text { Cottus beldingi }\end{array}$ & +++ & ++++ & ++ & +++ & ++++ & + & +++ & +++ & 0 & 0 & +++ & + \\
\hline $\begin{array}{l}\text { Margin sculpin } \\
\text { Cottus marginatus }\end{array}$ & +++ & ++++ & ++ & +++ & ++++ & + & ++++ & +++ & ++++ & 0 & +++ & 0 \\
\hline $\begin{array}{l}\text { Torrent sculpin } \\
\text { Cottus rhotheus }\end{array}$ & 0 & 0 & 0 & 0 & + & + & 0 & 0 & 0 & 0 & + & + \\
\hline
\end{tabular}


Notes:

1. The Upper Touchet is defined from the SF confluence to the town of Waitsburg. The Mid-Touchet is defined from Waitsburg to the Lamar Road, where it begins to run in a southerly direction. The Lower Touchet is defined from Lamar Rd to the confluence with the Walla Walla River.

2. The Upper Walla Walla is defined from the Oregon border to the Beet Road, just downstream of Burlingame Diversion at Mojonnier. The Lower Walla Walla is defined from the Beet Road to the Touchet-Gardena Road.

3. Two species of suckers were identified during the study; the large-scale sucker, Catostomus macrocheilus, and the bridgelip sucker, Catostomus columbianus. However, suckers were not speciated on all sites; where they were speciated; bridgelip suckers predominated.

Table 10. Stream reaches with suspected thermal barriers to salmonid passage or rearing.

\begin{tabular}{llccc}
\hline River & Reach & \multicolumn{1}{c}{$\begin{array}{c}\text { Probable } \\
\text { Barrier }\end{array}$} & $\begin{array}{c}\text { Sub-Optimal } \\
\text { Conditions }\end{array}$ & ${\text { Criteria }{ }^{1}}^{\text {Walla Walla }}$ \\
& $\begin{array}{l}\text { Oregon Border to Hwy 125 } \\
\text { Bridge } \\
\text { Burlingame Diversion to } \\
\text { Swegle Road }\end{array}$ & $\mathrm{X}$ & 1 \\
& $\begin{array}{l}\text { McDonald Road to } \\
\text { Touchet/Gardena Rd. }\end{array}$ & $\mathrm{X}$ & $\mathrm{X}$ & 1 \\
& $\begin{array}{l}\text { Coppei Creek to Lewis and } \\
\text { Clark State Park }\end{array}$ & & & $1,2,3$ \\
Touchet & $\begin{array}{l}\text { Mouth to Coppei Creek, } \\
\text { near Waitsburg }\end{array}$ & $\mathrm{X}$ & 2 \\
\hline
\end{tabular}

1 Criteria:

(1) mean temperature greater than $75^{\circ} \mathrm{F}$ for extended periods;

(2) spot daytime measurements $\geq 78^{\circ} \mathrm{F}$;

(3) salmonids absent from electrofishing and snorkeling sites within the reach.

\section{Genetic Population Sampling}

DNA samples were collected from 47 adult bull trout; seven from a trap at Nursery Bridge in Oregon and 40 from a trap on upper Mill Creek. DNA samples were collected from 84 adult steelhead, 77 at Nursery Bridge and seven at a trap on Yellowhawk Creek. In addition, 52 samples were obtained from juvenile steelhead in Mill Creek. Most of the juveniles collected at Mill Creek were at the parr stage of development; at this stage of maturity it is difficult to distinguish between anadromous steelhead and resident rainbow trout forms of the species $O$. mykiss.

Collected specimens were transported to the Genetics Stock Identification Lab in Olympia. Results of the genetic analysis are pending. 


\section{Literature Cited}

Armour, C.L. and Platts,W.S. 1983. Field methods and statistical analyses for monitoring small salmonid streams. US Fish and Wildlife Service. FWS/OBS-83/33. 200 pages.

Collier, M., Webb, R.H., and Schmidt, J.C. 1996. Dams and rivers: primer on the downstream effects of dams. US Geological Survey, Circular 1126. Tucson. 94 pages.

Committee on Protection and Management of Pacific Northwest Anadromous Salmonids, Board on Environmental Studies and Toxicology, and Commission on Life Sciences. 1996. Upstream: salmon and society in the Pacific Northwest. National Academy Press, Washington D.C. 452 pages.

Franklin,J.F. and Dyrness, C.T. 1973. Natural vegetation of Oregon and Washington. Oregon State University Press (1988 reprint). 452 pages.

Hedricks, P.W. 1996. Genetics of metapopulations: aspects of a comprehensive perspective. Pp 29-51, In: Metapopulations and wildlife conservation. McCullough,D.R., Ed. Island Press, Washington D.C.

Hicks, B.J, Hall, J.D., Bisson, P.A. and Sedell, J.R. 1991. Responses of salmonids to habitat changes. Pages 483-518, In: Influences of forest and rangeland management on salmonid fishes and their habitats. Meehan, W.R., ed. American Fisheries Society Special Publication 19. Evans City, PA.

Knutson,K.L., Jackson, S. Lovgren,T.,Hunter,M.,McDonald,D. 1992 Washington Rivers Information System: resident and anadromous fish data, 1:100,000 scale update. Washington Department of Wildlife, Olympia. 25 pages plus extensive appendices.

Lindeman, G. 1992. Golden harvest: the Columbia Plateau grain empire. Columbia, Summer 1992. Pp 20-28.

Mongillo,P.E. 1993. The distribution and status of bull trout/dolly varden in Washington State.

Washington Department of Wildlife, Olympia. 45 pages.

Mongillo,P.E. and Hallock, M. 1998. Washington State status report for the margined sculpin. WA Dept. Fish and Wildl., Olympia. 15 pages.

Neilson, R.S. 1950. Survey of the Columbia River and its Tributaries, Part 5. US Fish and Wildlife Service, Scientific Report, No. 38. 41 pages.

Olsen,J.B, Wenburg, J.K., and Benson, P. 1996. Semi-automated multilocus genotyping of Pacific salmon (Oncorhynchus spp.) Using microsatellites. Molecular. Marine Biol. and Biotech. 5:259-272. 
Pirtle, R. 1957. Field studies to establish the size and timing of runs of anadromous species of fish in the Columbia and Snake rivers and their distribution above the confluence of the Snake River. Final Report to the US Army Corps of Engineers, Idaho Fish and Game, Boise. 49pp plus appendices.

Platts,W.S., Megahan,W.F., and G.W. Minshall. 1983. Methods for evaluating stream, riparian, and biotic conditions. USDA Forest Service. Ogden. GTR.INT-138. 70 pages.

Simpson, J and Wallace,R. 1978. Fishes of Idaho. University of Idaho Press.237 pages.

Smith, M.R., Mattocks, P.W. Jr., and Cassidy, KM. 1997. Breeding birds of Washington State: Location data and predicted distributions.

Spencer, P. K. 1989. A small mammal fauna from the Touchet Beds of Walla Walla County, Washington: support for the multiple-flood hypothesis. Northwest Science 63(4): 167-174.

Tabor, R.D. 1976. Inventory of riparian habitats and associated wildlife along the Columbia River. US Army Corps of Engineers, Walla Walla. 861 pages.

US Army Corps of Engineers (ACOE) 1992. Walla Walla River Basin, Oregon and Washington: reconnaissance report. Walla Walla. 43 pages, plus extensive appendices.

US Army Corps of Engineers (ACOE) 1997. Walla Walla River Watershed, Oregon and Washington: reconnaissance report. Walla Walla. 78 pages, plus extensive appendices.

Van Deventer, J.S. and Platts,W.S. 1983. Sampling and estimating fish populations from streams. Trans. N. Am. Wildl. And Nat. Res. Conf. 48: 349-354.

Walla Walla Daily Journal. 1884. Young carp: the arrival of a government fish car at Walla Walla.

Washington Department of Fisheries (WDF) and Washington Department of Wildlife (WDW). 1993. 1992 Washington State salmon and steelhead stock inventory: Columbia River stocks. Olympia, WA. 579 pages.

Wydoski, R.S. and Whitney, R.R. 1979. Inland fishes of Washington. University of Washington Press, Seattle. 220 pages.

Zar, J.H. 1984. Biostatistical analysis. Prentice Hall, Inc. Englewood Cliffs, NJ. 718 pages. 


\section{Appendix A}

Study Site Locations 


\begin{tabular}{|c|c|c|}
\hline Watershed/Site \# & Landmark $^{1}$ & Location \\
\hline \multicolumn{3}{|l|}{ North Fork Touchet } \\
\hline NFT-1 & Sno-Park & $\begin{array}{l}0.5 \text { mile below Umatilla National Forest Sno-Park } \\
\text { lot, near culvert road crossing, North Fork Touchet } \\
\text { Road. }\end{array}$ \\
\hline NFT-2 & US Forest Service Boundary & $\begin{array}{l}0.1 \text { mile inside Forest Service Boundary, North } \\
\text { Fork Touchet Road. }\end{array}$ \\
\hline NFT-3 & Snake River Lab NF\#1 & $\begin{array}{l}7.1 \text { mile above Wolf Fork bridge, at NF Touchet } \\
\text { Road bridge crossing. }\end{array}$ \\
\hline NFT-4 & Snake River Lab NF\#2 & 1.7 mile above Wolf Fork bridge. \\
\hline NFT-5 & Snake River Lab NF\#3 & 0.1 mile below South Fork Road bridge. \\
\hline NFT-6 & Jim Creek & 75 feet above confluence with Jim Creek. \\
\hline
\end{tabular}

South Fork Touchet

SFT-1 Snake River Lab SF\#1

3.15 miles above Camp Nancy Lee bridge, just below forks confluence.

SFT-2 Snake River Lab SF\#2 $\quad 0.2$ below Camp Nancy Lee bridge.

SFT-3 Snake River Lab \#3 20 yards above Pettyjohn Road bridge.

\section{Wolf Fork Touchet}

WFT-1 Snake River Lab WFT\#1

1.3 miles above Wolf Fork Road bridge (on the North Touchet).

WFT-2 Snake River Lab WFT\#2

0.1 of a mile below the Robinson Fork bridge.

WFT-3 Snake River Lab WFT\#3

6.3 miles above the Robinson Fork bridge.

Robinson Fork

RFT-1 Broughton Gate

RFT-2 Lower Robinson Fork
End of public road, approximately 2.4 miles from beginning of Robinson Fork Road. Site is 50 feet above barbed wire fenceline across river.

Approximately 1.2 miles from beginning of Robinson Fork Road. First pull-over, barbed wire gate on left after one mile on odometer.

\section{Mainstem Touchet}

$$
\begin{array}{ll}
\text { TR-1 } & \text { snorkeling site } \\
\text { TR-2 } & \text { Upper Dayton Dike } \\
\text { TR-3 } & \text { snorkeling site }
\end{array}
$$$$
100 \text { feet below South Fork confluence. }
$$$$
\text { On dike, } 0.6 \text { mile from } 4^{\text {th }} \text { Avenue access. }
$$$$
500 \text { feet above spillway. }
$$

\section{Mainstem Touchet (cont.)}




\begin{tabular}{|c|c|c|c|}
\hline Watershed/Site \# & & Landmark $^{1}$ & Location \\
\hline & TR-4 & Snake River Lab intake & Below building at acclimation pond intake. \\
\hline & TR-5 & Playing field flagpole & $\begin{array}{l}\text { Off dike located behind Dayton High School } \\
\text { playing field, near the flagpole. }\end{array}$ \\
\hline & TR-6 & Highway 12 bridge, Dayton & 30 feet above bridge. \\
\hline & TR-7 & Golf Course & Near western property line. \\
\hline & TR-8 & Road 2441 & $\begin{array}{l}\text { Approximately } 300 \text { feet upstream of cattle ford, } \\
\text { Warren property. }\end{array}$ \\
\hline & TR-9 & County Farm Road & Just upstream of bridge. \\
\hline & TR-10 & Payne Hollow \#1 & Just below bridge. \\
\hline & TR-11 & Payne Hollow \#2 & 0.3 mile below $\# 1$. \\
\hline & TR-12 & Rose Gulch & Just upstream of bridge. \\
\hline & TR-13 & Lewis \& Clark State Park & Near eastern boundary of park. \\
\hline & TR-14 & Hogeye Hollow Road & $\begin{array}{l}\text { Approximately } 400 \text { feet below Sorghum Hollow } \\
\text { Road bridge. }\end{array}$ \\
\hline & TR-15 & Waitsburg City Park & $\begin{array}{l}\text { Approximately } 600 \text { feet downstream Highway } 12 \\
\text { bridge. }\end{array}$ \\
\hline & TR-16 & Old Cannery & $\begin{array}{l}0.5 \text { mile below first bridge on Cannery Road in } \\
\text { Waitsburg. }\end{array}$ \\
\hline & TR-17 & Knotgrass Road & At end of road, through field behind house. \\
\hline & TR-18 & Wood's Crossing & $\begin{array}{l}\text { Behind triple-wide at intersection of Bolles Road } \\
\text { and Menoken Road. }\end{array}$ \\
\hline & TR-19 & Bolles Bridge & $\begin{array}{l}\text { Approximately } 100 \text { feet upstream of Bolles } \\
\text { Bridge. }\end{array}$ \\
\hline & TR-20 & Lower Bolles & $\begin{array}{l}\text { Just below intermittent creek approximately } 0.6 \\
\text { mile below Bolles Bridge. }\end{array}$ \\
\hline & TR-21 & Hart Road & $\begin{array}{l}\text { Approximately 1,000 feet upstream Hart Road } \\
\text { bridge. }\end{array}$ \\
\hline & TR-22 & Flathers Bridge & $\begin{array}{l}\text { Approximately } 0.6 \text { mile below Flathers Bridge } \\
\text { (Hwy. 125) below high bank area. }\end{array}$ \\
\hline & TR-23 & Pettyjohn Bridge & 0.5 mile below Pettyjohn Road Bridge. \\
\hline & TR-24 & Lamar & $\begin{array}{l}\text { Approximately } 1 \text { mile before Ayer Road, just } \\
\text { above confluence with unnamed creek. }\end{array}$ \\
\hline & TR-25 & Burlington Northern & Below Lamar grain elevator. \\
\hline & TR-26 & Hoffman Road & $\begin{array}{l}\text { Approximately } 3.1 \text { mile down Hoffman Road, take } \\
\text { second dirt track to left leading down to river. Site } \\
\text { is } 500 \text { feet downstream from road end. }\end{array}$ \\
\hline
\end{tabular}




\begin{tabular}{|c|c|c|}
\hline Watershed/Site \# & Landmark $^{1}$ & Location \\
\hline \multicolumn{3}{|l|}{$\begin{array}{l}\text { Mainstem Touchet } \\
\text { (cont.) }\end{array}$} \\
\hline TR-27 & Plucker Road & $\begin{array}{l}0.5 \text { mile past first bridge over Touchet on North } \\
\text { Touchet Road. T9N, R33E, Sec } 11 \text {. }\end{array}$ \\
\hline TR-28 & Simms Road & $\begin{array}{l}\text { Electrofishing site } 500 \text { feet north of Simms Road } \\
\text { bridge, on WSDOT ownership. Temperature and } \\
\text { flow monitoring } 1,000 \text { feet below bridge on } \\
\text { WSDOT/WDFW ownership. }\end{array}$ \\
\hline TR-29 & Johnson Road & $\begin{array}{l}\text { First available pullout, just north of rocky hill near } \\
\text { Johnson Road, river bank is riprapped. }\end{array}$ \\
\hline TR-30 & LeGrow Road & $\begin{array}{l}\text { Below LeGrow Road approximately } 1,000 \text { feet } \\
\text { above powerline crossing. }\end{array}$ \\
\hline TR-31 & Touchet Gun Club & $\begin{array}{l}\text { Access on Conrad Road, west side of river. } \\
\text { Approximately } 200 \text { feet upstream from first dirt } \\
\text { track leading down to river. }\end{array}$ \\
\hline \multicolumn{3}{|l|}{$\begin{array}{l}\text { Coppei Creek } \\
\text { Mainstem }\end{array}$} \\
\hline $\mathrm{CC}-1$ & Coppei Road Bridge & 200 feet above McGowan Road bridge. \\
\hline $\mathrm{CC}-2$ & Old Airstrip & $\begin{array}{l}\text { Off Highway 12, T9N, R37E, Sec 25; directly } \\
\text { behind residence/business shop. }\end{array}$ \\
\hline $\mathrm{CC}-3$ & Meinburg Road & $\begin{array}{l}250 \text { feet below Meinburg Road bridge, site begins } \\
\text { next to residence/shop parking area. }\end{array}$ \\
\hline $\mathrm{CC}-4$ & Lower Coppei & $\begin{array}{l}\text { Above } 200 \text { feet upstream from Highway } 124 \\
\text { bridge. }\end{array}$ \\
\hline \multicolumn{3}{|l|}{ North Fork Coppei } \\
\hline NFC-1 & DNR Gate & $\begin{array}{l}\text { The DNR gate is located on small side road } \\
\text { leading to creek on left, just before North Coppei } \\
\text { Road begins upward climb. The electrofishing site } \\
\text { begins } 1,000 \text { feet beyond gate. }\end{array}$ \\
\hline NFC-2 & NF Coppei \#2 & $\begin{array}{l}0.925 \text { road miles above fork of Coppei/North } \\
\text { Coppei Roads. Mature riparian vegetation. }\end{array}$ \\
\hline NFC-3 & Haystock & $\begin{array}{l}0.325 \text { road miles above fork of Coppei/South } \\
\text { Coppei Roads, behind large old wood barn (no } \\
\text { other buildings), with huge haystack behind it. } \\
\text { Site is about } 300 \text { feet upstream from barn, in } \\
\text { pristine riparian setting. }\end{array}$ \\
\hline
\end{tabular}

South Fork Coppei

SFC-1 Barnes Road

SFC-2 Geir Road
About 200 feet below wide road junction at Barnes Road and South Coppei Road.

Down the ravine on the horseshoe turn at Geir Road and South Coppei Road. 


\begin{tabular}{|c|c|c|}
\hline Watershed/Site \# & Landmark $^{1}$ & Location \\
\hline \multicolumn{3}{|l|}{$\begin{array}{l}\text { South Fork Coppei } \\
\text { (cont.) }\end{array}$} \\
\hline SFC-3 & Walker Road & $\begin{array}{l}\text { On left at first stream crossing on South Coppei } \\
\text { Road, in flat just below Walker Road. About } 100 \\
\text { feet upstream of landowner's equipment } \\
\text { landing/gate. }\end{array}$ \\
\hline SFC-4 & Lower SF Coppei & $\begin{array}{l}0.44 \text { road miles from Y of Coppei Road/SF } \\
\text { Coppei Road. }\end{array}$ \\
\hline
\end{tabular}

\section{Walla Walla River}

WW-1 Peppers Bridge

WW-2 Highway 125

WW-3 Old MF Highway

WW-4 Mojonnier

WW-5 Beet Road

WW-6 Last Chance Road

WW-7 Swegle Road

WW-8 Detour Road

WW-9 McDonald Road

WW-10 Barney Road

WW-11 McKay Road
Electrofishing site about 200 feet downstream of Peppers Road bridge; monitoring site about 500 feet below bridge.

About 300 feet downstream of the Highway 125 bridge.

About 400 feet upstream of Old Milton Freewater Highway bridge, on portion of MF Highway west of Highway 125.

Just downstream from confluence of Yellowhawk Creek off Bussell Road.

About 150 feet downstream of old pumphouse that is about 600 feet below Beet Road bridge.

One-half mile downstream of Last Chance Road bridge. Accessed, with owner permission, on field road running on north side of river. Electrofishing site is located near ford and push-up dam.

300 feet upstream of the Swegle Road bridge.

Take Detour Road off Forest Road for $1 / 2$ mile. Site is well off road, on fence line between two ownerships. Very well-developed riparian forest at site.

About 700 feet above McDonald Road bridge.

Take Barney Road (right turn off west end of Detour Road), straight north to private drive and fence line. A well-worn field road leads north to a pump station. Electrofishing site is 600 feet downstream of pumphouse.

After turning on McKay Road turn left at first pumphouse, drive on primitive road across field to pumphouse on other side of field - park here. Down steep bank flow is 25 feet below pumphouse. Located after large deep pool. Electrofishing site is upstream of pool in a bend. 


\begin{tabular}{|c|c|c|}
\hline Watershed/Site \# & Landmark $^{1}$ & Location \\
\hline \multicolumn{3}{|c|}{ Yellowhawk Creek } \\
\hline & Carl Street & $\begin{array}{l}\text { In Walla Walla, follow Pleasant Street to end of } \\
\text { high school and turn right on School Road. Make } \\
\text { an immediate left on Carl Street and follow down } \\
\text { to where it bends. House with site is on right side } \\
\text { of street where it curves left. }\end{array}$ \\
\hline & Lower Yellowhawk & $\begin{array}{l}\text { On Old Milton Freewater Highway approximately } \\
1 / 2 \text { mile east of Highway } 125 \text {. Landowner's house } \\
\text { is white house on left. Take path on left side of } \\
\text { barn to creek. Monitor site is } 35 \text { feet downstream } \\
\text { of car hood on right bank where path meets creek. }\end{array}$ \\
\hline
\end{tabular}




\section{Appendix B}

\section{Daily Summaries of Instream Temperature and Flow}

Data 


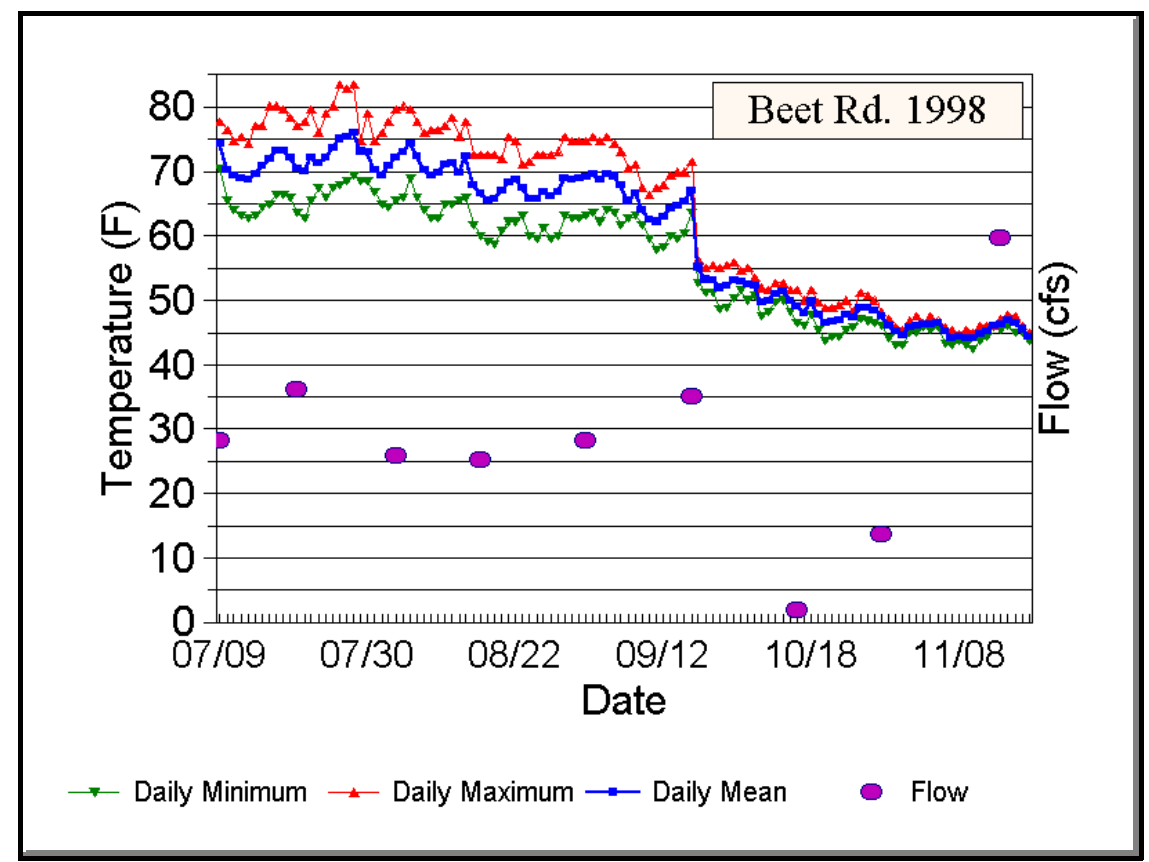

\section{Temperature Values for Continuous Instream Monitor Beet Road, Walla River, 1998}

Summary of Daily Temperature Values for the Continuous Instream Monitor Placed at Beet Road, Walla Walla River, 1998. Manual flows were also measured at the same location.

\begin{tabular}{|c|c|c|c|c|c|c|c|}
\hline Date & $\begin{array}{r}\text { Min } \\
\text { Time }\end{array}$ & $\begin{array}{r}\text { Min } \\
\text { Temp (F) } \\
\end{array}$ & $\begin{array}{r}\text { Max } \\
\text { Time }\end{array}$ & $\begin{array}{r}\text { Max } \\
\text { Temp (F) } \\
\end{array}$ & $\begin{array}{r}\text { Daily Temperature } \\
\text { Mean of means }\end{array}$ & $\begin{array}{r}\text { Flow } \\
(\mathbf{c f s}) \\
\end{array}$ & Notes \\
\hline $07 / 09 / 98$ & $12: 00$ & 70.5 & 08:00 & 77.7 & 74.3 & 28.3 & DOE Flow and Temp. \\
\hline $07 / 10 / 98$ & $12: 00$ & 65.5 & 08:00 & 76.6 & 70.3 & & monitor installed. \\
\hline
\end{tabular}


Summary of Daily Temperature Values for the Continuous Instream Monitor Placed at Beet Road, Walla Walla River, 1998. Manual flows were also measured at the same location.

\begin{tabular}{|c|c|c|c|c|c|c|c|}
\hline Date & $\begin{array}{c}\text { Min } \\
\text { Time }\end{array}$ & $\begin{array}{r}\text { Min } \\
\text { Temp (F) } \\
\end{array}$ & $\begin{array}{r}\text { Max } \\
\text { Time }\end{array}$ & $\begin{array}{r}\text { Max } \\
\text { Temp (F) } \\
\end{array}$ & $\begin{array}{r}\text { Daily Temperature } \\
\text { Mean of means }\end{array}$ & $\begin{array}{r}\text { Flow } \\
\text { (cfs) }\end{array}$ & Notes \\
\hline $07 / 11 / 98$ & 08:00 & 64.1 & 08:00 & 74.8 & 69.5 & & \\
\hline $07 / 12 / 98$ & 08:00 & 63.2 & 08:00 & 75.4 & 69.0 & & \\
\hline 07/13/98 & 08:00 & 62.7 & 08:00 & 74.3 & 68.7 & & \\
\hline $07 / 14 / 98$ & 08:00 & 63.2 & 08:00 & 77.1 & 69.6 & & \\
\hline $07 / 15 / 98$ & 08:00 & 64.5 & 08:00 & 77.1 & 70.8 & & \\
\hline $07 / 16 / 98$ & 08:00 & 65.0 & 08:00 & 80.2 & 71.9 & & \\
\hline $07 / 17 / 98$ & 08:00 & 66.4 & 08:00 & 80.2 & 73.3 & & \\
\hline $07 / 18 / 98$ & 08:00 & 66.4 & 08:00 & 79.6 & 73.2 & & \\
\hline $07 / 19 / 98$ & 08:00 & 66.0 & 08:00 & 78.4 & 72.2 & & \\
\hline $07 / 20 / 98$ & 08:00 & 63.6 & 08:00 & 77.1 & 70.5 & 36.1 & \\
\hline $07 / 21 / 98$ & 08:00 & 62.7 & 08:00 & 77.7 & 70.0 & & \\
\hline $07 / 22 / 98$ & 08:00 & 65.5 & 08:00 & 79.6 & 72.2 & & \\
\hline $07 / 23 / 98$ & 08:00 & 67.4 & $12: 00$ & 76.0 & 71.3 & & \\
\hline $07 / 24 / 98$ & 08:00 & 66.0 & 08:00 & 79.0 & 72.1 & & \\
\hline $07 / 25 / 98$ & 08:00 & 67.4 & 08:00 & 80.2 & 73.7 & & \\
\hline $07 / 26 / 98$ & 08:00 & 67.9 & 08:00 & 83.5 & 75.0 & & \\
\hline $07 / 27 / 98$ & 08:00 & 68.4 & 08:00 & 82.8 & 75.4 & & \\
\hline $07 / 28 / 98$ & 08:00 & 69.4 & 08:00 & 83.5 & 76.1 & & \\
\hline $07 / 29 / 98$ & 08:00 & 68.4 & 08:00 & 74.8 & 73.1 & & \\
\hline $07 / 30 / 98$ & 08:00 & 68.4 & 08:00 & 79.0 & 73.0 & & \\
\hline $07 / 31 / 98$ & $12: 00$ & 66.9 & $12: 00$ & 74.8 & 70.2 & & \\
\hline 08/01/98 & 08:00 & 65.0 & 08:00 & 76.0 & 69.4 & & \\
\hline $08 / 02 / 98$ & 08:00 & 64.5 & 08:00 & 77.7 & 70.8 & & \\
\hline 08/03/98 & 08:00 & 65.5 & 08:00 & 79.6 & 72.2 & 25.8 & \\
\hline 08/04/98 & 08:00 & 66.0 & 08:00 & 80.2 & 73.1 & & \\
\hline 08/05/98 & 08:00 & 68.9 & 08:00 & 79.6 & 74.3 & & \\
\hline 08/06/98 & 08:00 & 66.0 & 08:00 & 77.7 & 72.4 & & \\
\hline 08/07/98 & 08:00 & 64.1 & 08:00 & 76.0 & 70.2 & & \\
\hline 08/08/98 & 08:00 & 62.7 & 08:00 & 76.6 & 69.5 & & \\
\hline 08/09/98 & 08:00 & 62.7 & 08:00 & 76.6 & 69.8 & & \\
\hline 08/10/98 & 08:00 & 65.0 & 08:00 & 77.1 & 71.0 & & \\
\hline $08 / 11 / 98$ & 08:00 & 65.0 & 08:00 & 78.4 & 71.3 & & \\
\hline $08 / 12 / 98$ & 08:00 & 65.5 & $12: 00$ & 75.4 & 69.8 & & removed 12:00 hrs. \\
\hline $08 / 15 / 98$ & 08:00 & 66.0 & 08:00 & 77.7 & 72.3 & & reinstalled 08:00 hrs \\
\hline 08/16/98 & 08:00 & 61.8 & 08:00 & 72.6 & 67.8 & & \\
\hline 08/17/98 & 08:00 & 60.0 & 08:00 & 72.6 & 66.5 & 25.1 & \\
\hline 08/18/98 & 08:00 & 59.2 & 08:00 & 72.6 & 65.6 & & \\
\hline 08/19/98 & 08:00 & 58.8 & 08:00 & 72.6 & 65.8 & & \\
\hline $08 / 20 / 98$ & 08:00 & 60.9 & 08:00 & 72.1 & 67.0 & & \\
\hline $08 / 21 / 98$ & 08:00 & 62.2 & 08:00 & 75.4 & 68.2 & & \\
\hline
\end{tabular}


Summary of Daily Temperature Values for the Continuous Instream Monitor Placed at Beet Road, Walla Walla River, 1998. Manual flows were also measured at the same location.

\begin{tabular}{|c|c|c|c|c|c|c|c|}
\hline Date & $\begin{array}{r}\text { Min } \\
\text { Time }\end{array}$ & $\begin{array}{r}\text { Min } \\
\text { Temp (F) } \\
\end{array}$ & $\begin{array}{l}\text { Max } \\
\text { Time } \\
\end{array}$ & $\begin{array}{r}\text { Max } \\
\text { Temp (F) } \\
\end{array}$ & $\begin{array}{r}\text { Daily Temperature } \\
\text { Mean of means } \\
\end{array}$ & $\begin{array}{r}\text { Flow } \\
\text { (cfs) }\end{array}$ & Notes \\
\hline $08 / 22 / 98$ & 08:00 & 62.2 & 08:00 & 74.8 & 68.7 & & \\
\hline 08/23/98 & 08:00 & 63.2 & 08:00 & 71.0 & 67.5 & & \\
\hline $08 / 24 / 98$ & 08:00 & 60.0 & 08:00 & 71.5 & 65.8 & & \\
\hline $08 / 25 / 98$ & 08:00 & 59.6 & 08:00 & 72.6 & 65.8 & & \\
\hline $08 / 26 / 98$ & 08:00 & 61.4 & 08:00 & 72.6 & 66.9 & & \\
\hline $08 / 27 / 98$ & 08:00 & 59.6 & 08:00 & 72.6 & 66.3 & & \\
\hline $08 / 28 / 98$ & 08:00 & 60.0 & 08:00 & 73.2 & 66.8 & & \\
\hline 08/29/98 & 08:00 & 63.2 & 08:00 & 75.4 & 69.0 & & \\
\hline 08/30/98 & 08:00 & 62.7 & 08:00 & 74.8 & 68.7 & & \\
\hline $08 / 31 / 98$ & 08:00 & 62.7 & 08:00 & 74.8 & 69.0 & & \\
\hline 09/01/98 & 08:00 & 63.2 & 08:00 & 74.8 & 69.1 & 28.3 & \\
\hline 09/02/98 & 08:00 & 63.6 & 08:00 & 75.4 & 69.6 & & \\
\hline 09/03/98 & 08:00 & 62.2 & 08:00 & 74.8 & 68.8 & & \\
\hline 09/04/98 & 08:00 & 64.1 & 08:00 & 75.4 & 69.6 & & \\
\hline $09 / 05 / 98$ & 08:00 & 63.6 & 08:00 & 74.3 & 69.3 & & \\
\hline $09 / 06 / 98$ & 08:00 & 61.8 & 08:00 & 73.2 & 67.8 & & \\
\hline 09/07/98 & 08:00 & 62.7 & $12: 00$ & 70.5 & 65.4 & & \\
\hline 09/08/98 & 08:00 & 63.2 & $16: 00$ & 71.0 & 66.6 & & \\
\hline 09/09/98 & $12: 00$ & 61.8 & $12: 00$ & 67.4 & 64.0 & & \\
\hline 09/10/98 & 08:00 & 59.6 & 08:00 & 66.4 & 62.5 & & \\
\hline 09/11/98 & 08:00 & 57.9 & 08:00 & 67.4 & 62.2 & & \\
\hline $09 / 12 / 98$ & 08:00 & 58.3 & 08:00 & 67.9 & 63.0 & & \\
\hline 09/13/98 & 08:00 & 60.0 & 08:00 & 69.4 & 64.2 & & \\
\hline $09 / 14 / 98$ & 08:00 & 59.6 & 08:00 & 70.0 & 64.6 & & \\
\hline 09/15/98 & 08:00 & 60.5 & 08:00 & 70.0 & 65.2 & & \\
\hline \multirow[t]{2}{*}{ 09/16/98 } & 08:00 & 63.6 & 08:00 & 71.5 & 67.1 & 35.0 & \\
\hline & & & & & & & malfunction $9 / 16-10 / 1$ \\
\hline $10 / 02 / 98$ & $12: 00$ & 52.7 & $12: 00$ & 56.3 & 55.2 & & reinstalled 12:00 hrs \\
\hline $10 / 03 / 98$ & $12: 00$ & 51.2 & $12: 00$ & 55.1 & 53.2 & & \\
\hline $10 / 04 / 98$ & 08:00 & 51.2 & 08:00 & 55.5 & 53.1 & & \\
\hline $10 / 05 / 98$ & $12: 00$ & 48.6 & 08:00 & 55.1 & 52.0 & & \\
\hline $10 / 06 / 98$ & 08:00 & 49.0 & 08:00 & 55.5 & 52.2 & & \\
\hline $10 / 07 / 98$ & 08:00 & 50.4 & 08:00 & 55.9 & 53.2 & & \\
\hline $10 / 08 / 98$ & 08:00 & 51.6 & $12: 00$ & 54.7 & 52.8 & & \\
\hline $10 / 09 / 98$ & 08:00 & 50.1 & 08:00 & 55.1 & 52.5 & & \\
\hline $10 / 10 / 98$ & 08:00 & 50.8 & $12: 00$ & 53.5 & 52.3 & & \\
\hline $10 / 11 / 98$ & 08:00 & 47.5 & $12: 00$ & 51.9 & 49.6 & & \\
\hline $10 / 12 / 98$ & 08:00 & 48.2 & 08:00 & 51.6 & 49.9 & & \\
\hline $10 / 13 / 98$ & 08:00 & 49.7 & 08:00 & 52.7 & 51.0 & & \\
\hline $10 / 14 / 98$ & $12: 00$ & 50.1 & $16: 00$ & 52.7 & 51.4 & & \\
\hline
\end{tabular}


Summary of Daily Temperature Values for the Continuous Instream Monitor Placed at Beet Road, Walla Walla River, 1998. Manual flows were also measured at the same location.

\begin{tabular}{|c|c|c|c|c|c|c|c|}
\hline Date & $\begin{array}{c}\text { Min } \\
\text { Time }\end{array}$ & $\begin{array}{r}\text { Min } \\
\text { Temp (F) }\end{array}$ & $\begin{array}{l}\text { Max } \\
\text { Time }\end{array}$ & $\begin{array}{r}\text { Max } \\
\text { Temp (F) }\end{array}$ & $\begin{array}{r}\text { Daily Temperature } \\
\text { Mean of means }\end{array}$ & $\begin{array}{r}\text { Flow } \\
\text { (cfs) }\end{array}$ & Notes \\
\hline $10 / 15 / 98$ & 08:00 & 48.2 & 08:00 & 51.6 & 50.0 & & \\
\hline $10 / 16 / 98$ & $12: 00$ & 46.5 & $16: 00$ & 51.6 & 49.2 & 1.8 & \\
\hline $10 / 17 / 98$ & 08:00 & 46.1 & 08:00 & 50.1 & 48.1 & & \\
\hline $10 / 18 / 98$ & $12: 00$ & 47.9 & $16: 00$ & 51.6 & 49.8 & & \\
\hline $10 / 19 / 98$ & 08:00 & 45.4 & $12: 00$ & 49.7 & 47.8 & & \\
\hline $10 / 20 / 98$ & $12: 00$ & 43.7 & 08:00 & 49.0 & 46.6 & & \\
\hline $10 / 21 / 98$ & 08:00 & 44.4 & 08:00 & 49.0 & 46.7 & & \\
\hline $10 / 22 / 98$ & $12: 00$ & 44.4 & 08:00 & 49.3 & 46.9 & & \\
\hline $10 / 23 / 98$ & $12: 00$ & 45.4 & 08:00 & 50.1 & 47.8 & & \\
\hline $10 / 24 / 98$ & 08:00 & 45.8 & 08:00 & 48.2 & 47.4 & & \\
\hline $10 / 25 / 98$ & 08:00 & 47.2 & 08:00 & 51.2 & 48.8 & & \\
\hline $10 / 26 / 98$ & 08:00 & 46.8 & 08:00 & 50.8 & 48.9 & & \\
\hline $10 / 27 / 98$ & 08:00 & 46.5 & 08:00 & 50.1 & 48.4 & & \\
\hline $10 / 28 / 98$ & $12: 00$ & 46.1 & $12: 00$ & 48.2 & 47.7 & 13.7 & \\
\hline $10 / 29 / 98$ & $12: 00$ & 44.1 & $12: 00$ & 47.2 & 46.1 & & \\
\hline $10 / 30 / 98$ & $12: 00$ & 43.0 & $12: 00$ & 45.8 & 45.1 & & \\
\hline $10 / 31 / 98$ & 08:00 & 43.0 & 08:00 & 45.4 & 44.6 & & \\
\hline $11 / 01 / 98$ & 08:00 & 45.1 & 08:00 & 46.8 & 45.8 & & \\
\hline $11 / 02 / 98$ & $16: 00$ & 45.1 & 08:00 & 47.5 & 46.1 & & \\
\hline $11 / 03 / 98$ & $12: 00$ & 45.8 & $12: 00$ & 46.5 & 46.4 & & \\
\hline $11 / 04 / 98$ & $16: 00$ & 45.4 & 08:00 & 47.5 & 46.2 & & \\
\hline $11 / 05 / 98$ & 08:00 & 45.8 & $12: 00$ & 46.8 & 46.5 & & \\
\hline $11 / 06 / 98$ & $12: 00$ & 43.4 & 08:00 & 45.8 & 45.2 & & \\
\hline $11 / 07 / 98$ & $12: 00$ & 43.0 & $12: 00$ & 45.4 & 44.2 & & \\
\hline $11 / 08 / 98$ & $12: 00$ & 43.7 & 08:00 & 44.7 & 44.4 & & \\
\hline $11 / 09 / 98$ & 08:00 & 43.0 & 08:00 & 45.4 & 44.2 & & \\
\hline $11 / 10 / 98$ & $12: 00$ & 42.4 & 08:00 & 45.1 & 44.1 & & \\
\hline $11 / 11 / 98$ & 08:00 & 43.7 & 08:00 & 46.1 & 44.7 & & \\
\hline $11 / 12 / 98$ & $16: 00$ & 44.4 & 08:00 & 46.1 & 45.3 & & \\
\hline $11 / 13 / 98$ & $12: 00$ & 45.8 & $12: 00$ & 46.1 & 46.1 & & \\
\hline $11 / 14 / 98$ & 08:00 & 45.4 & 08:00 & 47.2 & 46.2 & 59.5 & \\
\hline $11 / 15 / 98$ & 08:00 & 46.1 & 08:00 & 47.9 & 46.9 & & \\
\hline $11 / 16 / 98$ & $12: 00$ & 45.1 & $12: 00$ & 47.5 & 46.5 & & \\
\hline $11 / 17 / 98$ & $12: 00$ & 45.1 & $12: 00$ & 46.1 & 45.5 & & \\
\hline $11 / 18 / 98$ & 08:00 & 43.7 & $12: 00$ & 45.1 & 44.5 & & $\begin{array}{l}\text { removed 12:00 hrs. } \\
11 / 19 / 98\end{array}$ \\
\hline
\end{tabular}




\section{Summary of Daily Temperature Values for the Continuous Instream Monitor Placed at the Carl Street Site, Upper Yellowhawk Creek, 1998}

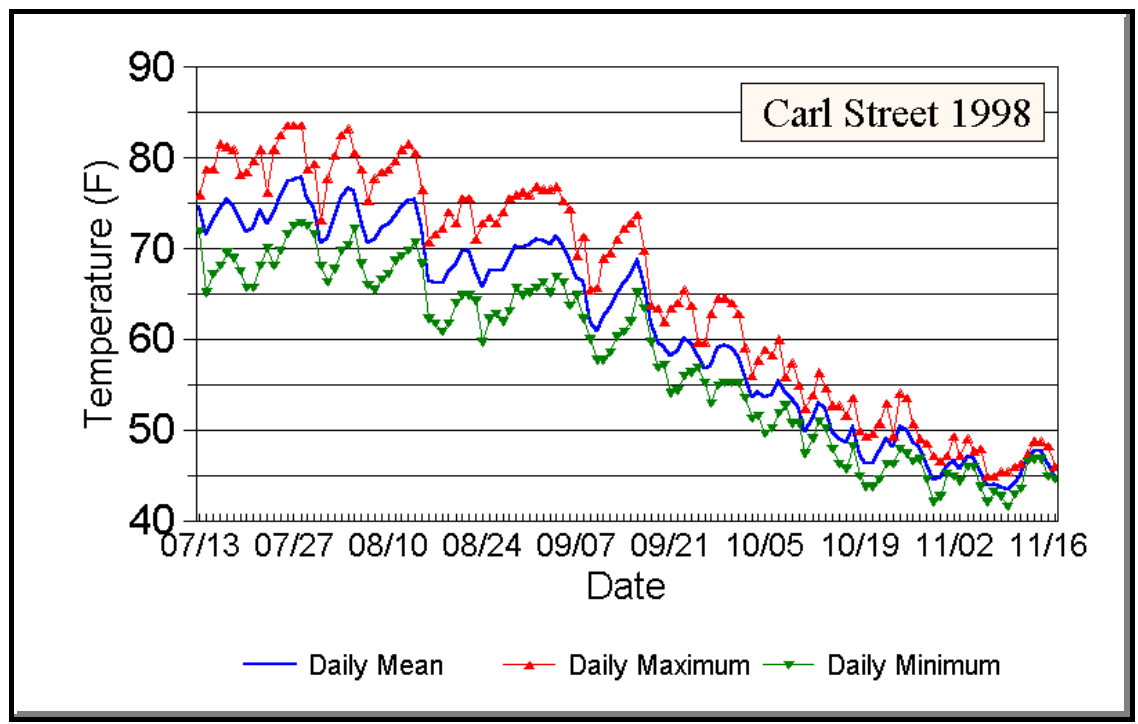

Summary of Daily Temperature Values for the Continuous Instream Monitor Placed at the Carl Street Site, Upper Yellowhawk Creek, 1998.

\begin{tabular}{lcccccc}
\hline Date & $\begin{array}{c}\text { Min } \\
\text { Time }\end{array}$ & $\begin{array}{r}\text { Min } \\
\text { Temp }\end{array}$ & $\begin{array}{r}\text { Max } \\
\text { Time }\end{array}$ & $\begin{array}{r}\text { Max } \\
\text { Temp }(\mathbf{F})\end{array}$ & $\begin{array}{c}\text { Daily } \\
\text { Mean }\end{array}$ & $\begin{array}{c}\text { Daily } \\
\text { Mode Notes }\end{array}$ \\
\hline $07 / 13 / 98$ & $23: 30$ & 71.9 & $19: 00$ & 75.9 & 74.5 & 75.0 monitor installed 17:00 hrs. \\
$07 / 14 / 98$ & $07: 30$ & 65.1 & $19: 30$ & 78.7 & 71.5 & 65.0 \\
$07 / 15 / 98$ & $08: 30$ & 67.2 & $18: 30$ & 78.7 & 73.2 & 79.0 \\
$07 / 16 / 98$ & $07: 30$ & 68.1 & $18: 30$ & 81.6 & 74.5 & 68.0 \\
$07 / 17 / 98$ & $09: 00$ & 69.5 & $19: 00$ & 81.3 & 75.4 & 70.0 \\
$07 / 18 / 98$ & $09: 00$ & 68.9 & $19: 30$ & 81.0 & 74.8 & 70.0 \\
$07 / 19 / 98$ & $08: 30$ & 67.5 & $18: 30$ & 78.1 & 73.1 & 68.0 \\
$07 / 20 / 98$ & $08: 30$ & 65.7 & $18: 55$ & 78.4 & 71.9 & 66.0 \\
$07 / 21 / 98$ & $08: 55$ & 65.7 & $18: 55$ & 79.7 & 72.3 & 66.0 \\
$07 / 22 / 98$ & $07: 55$ & 68.1 & $18: 25$ & 81.0 & 74.3 & 68.0 \\
$07 / 23 / 98$ & $08: 25$ & 70.1 & $00: 25$ & 76.2 & 72.8 & 73.0 \\
$07 / 24 / 98$ & $08: 55$ & 68.1 & $19: 55$ & 81.0 & 74.0 & 70.0 \\
$07 / 25 / 98$ & $08: 55$ & 69.8 & $19: 55$ & 82.6 & 75.9 & 70.0 \\
$07 / 26 / 98$ & $08: 25$ & 71.6 & $19: 25$ & 83.6 & 77.4 & 72.0 \\
$07 / 27 / 98$ & $08: 25$ & 72.5 & $18: 25$ & 83.6 & 77.6 & 73.0 \\
$07 / 28 / 98$ & $07: 55$ & 72.8 & $18: 25$ & 83.6 & 77.9 & 73.0 \\
$07 / 29 / 98$ & $07: 25$ & 72.5 & $19: 25$ & 78.7 & 75.6 & 73.0 \\
$07 / 30 / 98$ & $07: 55$ & 71.6 & $17: 55$ & 79.4 & 74.7 & 72.0
\end{tabular}


Summary of Daily Temperature Values for the Continuous Instream Monitor Placed at the Carl Street Site, Upper Yellowhawk Creek, 1998.

\begin{tabular}{|c|c|c|c|c|c|c|}
\hline Date & $\begin{array}{c}\text { Min } \\
\text { Time }\end{array}$ & $\begin{array}{r}\text { Min } \\
\text { Temp (F) }\end{array}$ & $\begin{array}{l}\text { Max } \\
\text { Time }\end{array}$ & $\begin{array}{r}\text { Max } \\
\text { Temp (F) }\end{array}$ & $\begin{array}{l}\text { Daily } \\
\text { Mean }\end{array}$ & $\begin{array}{l}\text { Daily } \\
\text { Mode Notes }\end{array}$ \\
\hline $07 / 31 / 98$ & $10: 55$ & 68.1 & $00: 55$ & 73.1 & 70.6 & 72.0 \\
\hline 08/01/98 & $09: 55$ & 66.3 & $19: 25$ & 77.8 & 71.2 & 67.0 \\
\hline 08/02/98 & $08: 25$ & 67.8 & $19: 25$ & 80.3 & 73.4 & 68.0 \\
\hline 08/03/98 & $06: 55$ & 69.8 & $18: 25$ & 82.6 & 75.8 & 70.0 \\
\hline 08/04/98 & $07: 25$ & 70.4 & $18: 25$ & 83.2 & 76.6 & 83.0 \\
\hline 08/05/98 & $08: 25$ & 72.2 & $18: 25$ & 80.6 & 76.3 & 80.0 \\
\hline 08/06/98 & $08: 25$ & 68.4 & $18: 55$ & 78.7 & 73.2 & 69.0 \\
\hline 08/07/98 & $08: 55$ & 66.0 & $18: 55$ & 75.3 & 70.6 & 75.0 \\
\hline 08/08/98 & $08: 25$ & 65.4 & $19: 25$ & 77.8 & 71.1 & 65.0 \\
\hline 08/09/98 & $07: 55$ & 66.6 & $18: 25$ & 78.4 & 72.2 & 67.0 \\
\hline 08/10/98 & $08: 55$ & 67.2 & $18: 25$ & 78.7 & 72.7 & 67.0 \\
\hline $08 / 11 / 98$ & $07: 55$ & 68.6 & $18: 55$ & 79.7 & 73.7 & 69.0 \\
\hline $08 / 12 / 98$ & $08: 25$ & 69.2 & $19: 25$ & 81.0 & 74.6 & 70.0 \\
\hline $08 / 13 / 98$ & $07: 25$ & 69.8 & $18: 55$ & 81.6 & 75.4 & 70.0 \\
\hline 08/14/98 & $07: 25$ & 70.7 & $18: 25$ & 80.6 & 75.5 & 71.0 \\
\hline $08 / 15 / 98$ & $08: 55$ & 68.4 & $16: 55$ & 76.5 & 72.3 & 69.0 \\
\hline $08 / 16 / 98$ & $09: 25$ & 62.3 & $19: 25$ & 70.7 & 66.5 & 63.0 \\
\hline $08 / 17 / 98$ & $08: 25$ & 61.7 & $18: 28$ & 71.6 & 66.3 & 62.0 \\
\hline 08/18/98 & $07: 28$ & 60.8 & $18: 28$ & 72.2 & 66.2 & 61.0 \\
\hline $08 / 19 / 98$ & $07: 58$ & 61.7 & $18: 28$ & 74.0 & 67.4 & 62.0 \\
\hline $08 / 20 / 98$ & $08: 28$ & 64.0 & $16: 58$ & 72.8 & 68.3 & 64.0 \\
\hline $08 / 21 / 98$ & $07: 28$ & 64.9 & $18: 58$ & 75.6 & 69.7 & 65.0 \\
\hline $08 / 22 / 98$ & $07: 58$ & 64.9 & $18: 28$ & 75.6 & 69.9 & 65.0 \\
\hline $08 / 23 / 98$ & $08: 58$ & 64.3 & $17: 58$ & 71.0 & 67.6 & 65.0 \\
\hline $08 / 24 / 98$ & $07: 58$ & 59.7 & $18: 58$ & 72.8 & 65.7 & 60.0 \\
\hline $08 / 25 / 98$ & $07: 28$ & 62.3 & $18: 58$ & 73.4 & 67.6 & 63.0 \\
\hline $08 / 26 / 98$ & $08: 28$ & 62.8 & $17: 58$ & 72.8 & 67.5 & 63.0 \\
\hline $08 / 27 / 98$ & $07: 58$ & 62.0 & $18: 28$ & 74.0 & 67.6 & 63.0 \\
\hline $08 / 28 / 98$ & $07: 28$ & 63.1 & $18: 28$ & 75.6 & 68.9 & 63.0 \\
\hline $08 / 29 / 98$ & $08: 28$ & 65.7 & $18: 28$ & 75.9 & 70.2 & 66.0 \\
\hline $08 / 30 / 98$ & $07: 58$ & 64.9 & $18: 28$ & 76.2 & 70.1 & 65.0 \\
\hline $08 / 31 / 98$ & $07: 28$ & 65.1 & $17: 28$ & 75.9 & 70.4 & 76.0 \\
\hline 09/01/98 & $07: 28$ & 65.7 & $17: 28$ & 76.9 & 71.0 & 66.0 \\
\hline $09 / 02 / 98$ & $08: 58$ & 66.3 & $17: 58$ & 76.5 & 71.0 & 67.0 \\
\hline 09/03/98 & $08: 28$ & 65.1 & $18: 58$ & 76.5 & 70.6 & 65.0 \\
\hline 09/04/98 & $07: 58$ & 66.9 & $17: 58$ & 76.9 & 71.4 & 67.0 \\
\hline $09 / 05 / 98$ & $08: 28$ & 66.3 & $18: 28$ & 75.3 & 70.5 & 67.0 \\
\hline 09/06/98 & $07: 28$ & 63.7 & $18: 58$ & 74.4 & 68.9 & 64.0 \\
\hline 09/07/98 & $07: 58$ & 64.9 & $00: 28$ & 69.2 & 66.8 & 67.0 \\
\hline 09/08/98 & $08: 28$ & 62.3 & $16: 58$ & 71.3 & 66.4 & 63.0 \\
\hline
\end{tabular}


Summary of Daily Temperature Values for the Continuous Instream Monitor Placed at the Carl Street Site, Upper Yellowhawk Creek, 1998.

\begin{tabular}{|c|c|c|c|c|c|c|}
\hline Date & $\begin{array}{c}\text { Min } \\
\text { Time }\end{array}$ & $\begin{array}{r}\text { Min } \\
\text { Temp (F) }\end{array}$ & $\begin{array}{l}\text { Max } \\
\text { Time }\end{array}$ & $\begin{array}{r}\text { Max } \\
\text { Temp (F) }\end{array}$ & $\begin{array}{l}\text { Daily } \\
\text { Mean }\end{array}$ & $\begin{array}{l}\text { Daily } \\
\text { Mode Notes }\end{array}$ \\
\hline 09/09/98 & $10: 28$ & 60.0 & $00: 28$ & 65.4 & 61.9 & 61.0 \\
\hline 09/10/98 & $09: 28$ & 57.7 & $17: 58$ & 65.7 & 60.9 & 59.0 \\
\hline 09/11/98 & $07: 58$ & 57.7 & $17: 28$ & 68.9 & 62.4 & 58.0 \\
\hline 09/12/98 & $08: 28$ & 58.5 & $18: 28$ & 69.5 & 63.5 & 59.0 \\
\hline 09/13/98 & $07: 58$ & 60.3 & $17: 58$ & 71.0 & 65.0 & 61.0 \\
\hline 09/14/98 & $07: 58$ & 60.8 & $17: 58$ & 72.2 & 66.2 & 61.0 \\
\hline 09/15/98 & $08: 28$ & 62.0 & $17: 58$ & 72.8 & 67.1 & 63.0 \\
\hline 09/16/98 & $08: 58$ & 65.1 & $17: 28$ & 73.7 & 68.8 & 65.0 \\
\hline 09/17/98 & $08: 28$ & 63.4 & $18: 28$ & 69.8 & 66.1 & 65.0 \\
\hline 09/18/98 & $23: 58$ & 59.7 & $17: 28$ & 63.7 & 61.7 & 61.0 \\
\hline 09/19/98 & $07: 58$ & 56.9 & $17: 28$ & 63.4 & 59.7 & 57.0 \\
\hline 09/20/98 & $08: 28$ & 57.1 & $17: 58$ & 62.0 & 59.2 & 61.0 \\
\hline 09/21/98 & $07: 58$ & 54.1 & $16: 58$ & 63.4 & 58.3 & 55.0 \\
\hline 09/22/98 & $07: 58$ & 54.4 & $16: 28$ & 64.0 & 58.8 & 55.0 \\
\hline $09 / 23 / 98$ & $08: 28$ & 56.0 & $17: 28$ & 65.4 & 60.2 & 65.0 \\
\hline $09 / 24 / 98$ & $07: 28$ & 56.3 & $16: 28$ & 63.7 & 59.5 & 57.0 \\
\hline $09 / 25 / 98$ & $08: 28$ & 56.9 & $16: 28$ & 59.7 & 58.1 & 57.0 \\
\hline $09 / 26 / 98$ & $07: 58$ & 55.2 & $16: 58$ & 59.7 & 56.8 & 56.0 \\
\hline 09/27/98 & $07: 58$ & 53.0 & $17: 28$ & 62.8 & 57.2 & 54.0 \\
\hline 09/28/98 & $07: 58$ & 54.9 & $17: 28$ & 64.6 & 59.0 & 55.0 \\
\hline 09/29/98 & $07: 58$ & 55.2 & $17: 48$ & 64.6 & 59.3 & 57.0 \\
\hline 09/30/98 & 09:18 & 55.2 & $16: 48$ & 64.0 & 59.1 & 55.0 \\
\hline $10 / 01 / 98$ & 08:18 & 55.2 & $17: 18$ & 62.8 & 58.1 & 56.0 \\
\hline $10 / 02 / 98$ & 08:48 & 53.5 & $17: 18$ & 59.1 & 55.8 & 55.0 \\
\hline $10 / 03 / 98$ & $08: 48$ & 51.3 & $16: 18$ & 56.0 & 53.6 & 52.0 \\
\hline $10 / 04 / 98$ & 08:48 & 51.6 & $17: 48$ & 57.7 & 54.2 & 52.0 \\
\hline $10 / 05 / 98$ & $07: 48$ & 49.6 & $17: 18$ & 58.8 & 53.7 & 50.0 \\
\hline $10 / 06 / 98$ & 08:18 & 50.2 & $17: 18$ & 58.3 & 53.9 & 55.0 \\
\hline $10 / 07 / 98$ & $07: 48$ & 51.8 & $16: 48$ & 60.0 & 55.5 & 54.0 \\
\hline $10 / 08 / 98$ & $23: 48$ & 52.7 & $16: 18$ & 55.8 & 54.2 & 55.0 \\
\hline $10 / 09 / 98$ & $07: 48$ & 50.7 & $15: 48$ & 57.4 & 53.5 & 51.0 \\
\hline $10 / 10 / 98$ & $08: 48$ & 50.7 & $14: 48$ & 54.9 & 52.5 & 51.0 \\
\hline $10 / 11 / 98$ & 09:18 & 47.4 & $17: 18$ & 52.4 & 49.9 & 48.0 \\
\hline $10 / 12 / 98$ & $07: 18$ & 49.0 & $17: 48$ & 53.8 & 51.2 & 50.0 \\
\hline $10 / 13 / 98$ & $06: 48$ & 51.0 & $17: 48$ & 56.3 & 53.0 & 51.0 \\
\hline $10 / 14 / 98$ & $23: 48$ & 50.2 & $14: 48$ & 54.6 & 52.4 & 52.0 \\
\hline $10 / 15 / 98$ & 08:48 & 47.9 & $17: 18$ & 52.7 & 49.8 & 48.0 \\
\hline $10 / 16 / 98$ & 08:48 & 46.3 & $17: 18$ & 52.7 & 49.0 & 48.0 \\
\hline $10 / 17 / 98$ & $07: 48$ & 45.7 & $17: 48$ & 51.6 & 48.6 & 51.0 \\
\hline $10 / 18 / 98$ & 09:48 & 48.2 & $16: 48$ & 53.5 & 50.4 & 50.0 \\
\hline
\end{tabular}


Summary of Daily Temperature Values for the Continuous Instream Monitor Placed at the Carl Street Site, Upper Yellowhawk Creek, 1998.

\begin{tabular}{|c|c|c|c|c|c|c|c|}
\hline Date & $\begin{array}{r}\text { Min } \\
\text { Time }\end{array}$ & $\begin{array}{r}\text { Min } \\
\text { Temp (F) }\end{array}$ & $\begin{array}{r}\text { Max } \\
\text { Time }\end{array}$ & $\begin{array}{r}\text { Max } \\
\text { Temp (F) } \\
\end{array}$ & $\begin{array}{l}\text { Daily } \\
\text { Mean }\end{array}$ & $\begin{array}{l}\text { Daily } \\
\text { Mode }\end{array}$ & Notes \\
\hline $10 / 19 / 98$ & $08: 48$ & 44.9 & $16: 18$ & 49.9 & 47.2 & 47.0 & \\
\hline $10 / 20 / 98$ & 08:48 & 43.8 & $15: 48$ & 49.3 & 46.2 & 46.0 & \\
\hline $10 / 21 / 98$ & $08: 18$ & 43.8 & $16: 18$ & 49.6 & 46.4 & 45.0 & \\
\hline $10 / 22 / 98$ & 08:18 & 44.6 & $17: 18$ & 50.7 & 47.6 & 45.0 & \\
\hline $10 / 23 / 98$ & $08: 18$ & 46.3 & $16: 48$ & 53.0 & 49.0 & 47.0 & \\
\hline $10 / 24 / 98$ & 08:48 & 46.3 & $16: 48$ & 49.3 & 48.1 & 49.0 & \\
\hline $10 / 25 / 98$ & 09:18 & 47.9 & $16: 48$ & 54.1 & 50.3 & 49.0 & \\
\hline $10 / 26 / 98$ & 09:18 & 47.4 & $17: 18$ & 53.5 & 50.0 & 48.0 & \\
\hline $10 / 27 / 98$ & 08:48 & 46.5 & $16: 18$ & 50.7 & 48.7 & 49.0 & \\
\hline $10 / 28 / 98$ & 08:48 & 46.8 & $15: 14$ & 49.0 & 48.1 & 48.0 & \\
\hline $10 / 29 / 98$ & 09:14 & 44.6 & $15: 14$ & 48.5 & 46.3 & 45.0 & \\
\hline $10 / 30 / 98$ & 08:44 & 42.1 & $16: 14$ & 47.1 & 44.6 & 45.0 & \\
\hline $10 / 31 / 98$ & 08:14 & 42.6 & $16: 14$ & 46.5 & 44.8 & 46.0 & \\
\hline $11 / 01 / 98$ & $23: 14$ & 45.1 & $16: 14$ & 47.1 & 46.1 & 46.0 & \\
\hline $11 / 02 / 98$ & $07: 14$ & 44.9 & $16: 44$ & 49.3 & 46.7 & 45.0 & \\
\hline $11 / 03 / 98$ & 09:44 & 44.3 & $01: 14$ & 47.1 & 45.7 & 46.0 & \\
\hline $11 / 04 / 98$ & $06: 44$ & 46.0 & $17: 44$ & 49.0 & 47.1 & 46.0 & \\
\hline $11 / 05 / 98$ & $23: 44$ & 46.0 & $00: 14$ & 47.7 & 46.9 & 47.0 & \\
\hline $11 / 06 / 98$ & 08:14 & 43.8 & $16: 14$ & 47.9 & 45.6 & 45.0 & \\
\hline $11 / 07 / 98$ & 09:14 & 42.1 & $15: 44$ & 44.9 & 43.9 & 45.0 & \\
\hline $11 / 08 / 98$ & $23: 44$ & 43.2 & 01:14 & 44.9 & 44.0 & 44.0 & \\
\hline $11 / 09 / 98$ & 09:14 & 42.6 & $16: 44$ & 45.4 & 43.7 & 43.0 & \\
\hline $11 / 10 / 98$ & 08:44 & 41.5 & $15: 44$ & 45.4 & 43.4 & 43.0 & \\
\hline $11 / 11 / 98$ & $06: 44$ & 42.9 & $17: 14$ & 46.0 & 44.2 & 43.0 & \\
\hline $11 / 12 / 98$ & $07: 14$ & 43.5 & $15: 14$ & 46.3 & 45.0 & 46.0 & \\
\hline $11 / 13 / 98$ & 01:14 & 46.5 & $20: 14$ & 47.4 & 47.0 & 47.0 & \\
\hline $11 / 14 / 98$ & 07:14 & 46.8 & $17: 44$ & 48.8 & 47.7 & 47.0 & \\
\hline $11 / 15 / 98$ & 07:14 & 46.8 & $16: 44$ & 48.8 & 47.8 & 47.0 & \\
\hline $11 / 16 / 98$ & 08:44 & 44.9 & $01: 14$ & 48.2 & 46.3 & 46.0 & \\
\hline $11 / 17 / 98$ & 10:14 & 44.6 & $00: 14$ & 46.0 & 45.0 & 45.0 & monitor removed 15:14 hrs. \\
\hline
\end{tabular}




\section{Summary of Daily Temperature Values for the Continuous Instream Monitor Placed in Lower Coppei Creek, 1998}

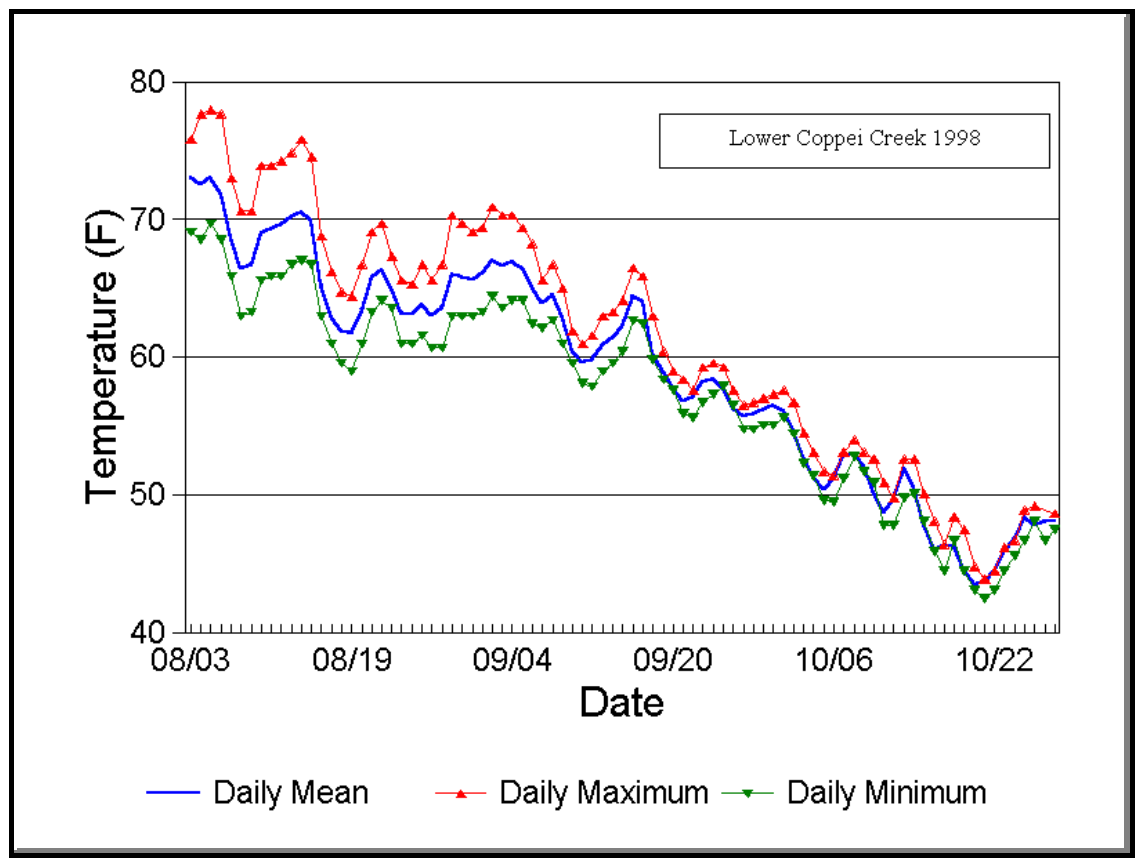

Summary of Daily Temperature Values for the Continuous Instream Monitor Placed in Lower Coppei Creek, 1998.

\begin{tabular}{lrrrrrrl}
\hline Date & $\begin{array}{r}\text { Min } \\
\text { Time }\end{array}$ & $\begin{array}{r}\text { Min } \\
\text { Temp (F) }\end{array}$ & $\begin{array}{r}\text { Max } \\
\text { Time }\end{array}$ & $\begin{array}{r}\text { Max } \\
\text { Temp (F) }\end{array}$ & $\begin{array}{r}\text { Daily } \\
\text { Mean (F) }\end{array}$ & $\begin{array}{c}\text { Daily } \\
\text { Mode }\end{array}$ & Notes \\
\hline $08 / 03 / 98$ & $09: 29$ & 69.1 & $15: 29$ & 75.8 & 73.1 & 72.0 & monitor installed 09:29 hrs. \\
$08 / 04 / 98$ & $05: 59$ & 68.5 & $15: 59$ & 77.7 & 72.6 & 69.0 & \\
$08 / 05 / 98$ & $06: 29$ & 69.7 & $13: 59$ & 78.0 & 73.0 & 71.0 & \\
$08 / 06 / 98$ & $08: 29$ & 68.5 & $16: 29$ & 77.7 & 71.8 & 69.0 & \\
$08 / 07 / 98$ & $08: 59$ & 65.9 & $15: 29$ & 73.0 & 68.6 & 66.0 & \\
$08 / 08 / 98$ & $07: 29$ & 63.0 & $15: 29$ & 70.6 & 66.4 & 64.0 & \\
$08 / 09 / 98$ & $06: 29$ & 63.3 & $15: 59$ & 70.6 & 66.8 & 64.0 & \\
$08 / 10 / 98$ & $06: 29$ & 65.6 & $16: 29$ & 73.9 & 69.1 & 66.0 & \\
$08 / 11 / 98$ & $05: 59$ & 65.9 & $15: 59$ & 73.9 & 69.3 & 66.0 & \\
$08 / 12 / 98$ & $06: 59$ & 65.9 & $15: 29$ & 74.2 & 69.6 & 66.0 & \\
$08 / 13 / 98$ & $07: 29$ & 66.8 & $15: 59$ & 74.8 & 70.2 & 67.0 & \\
$08 / 14 / 98$ & $07: 29$ & 67.1 & $14: 59$ & 75.8 & 70.6 & 68.0 & \\
$08 / 15 / 98$ & $23: 59$ & 66.8 & $15: 29$ & 74.5 & 69.9 & 68.0 & \\
$08 / 16 / 98$ & $09: 59$ & 63.0 & $15: 29$ & 68.8 & 65.2 & 63.0 & \\
$08 / 17 / 98$ & $09: 29$ & 61.0 & $14: 29$ & 66.2 & 62.9 & 62.0 & \\
$08 / 18 / 98$ & $06: 59$ & 59.6 & $15: 29$ & 64.7 & 61.9 & 60.0 & \\
$08 / 19 / 98$ & $06: 59$ & 59.0 & $14: 29$ & 64.4 & 61.7 & 64.0 & \\
\hline
\end{tabular}


Summary of Daily Temperature Values for the Continuous Instream Monitor Placed in Lower Coppei Creek, 1998.

\begin{tabular}{|c|c|c|c|c|c|c|c|}
\hline Date & $\begin{array}{l}\text { Min } \\
\text { Time }\end{array}$ & $\begin{array}{r}\text { Min } \\
\text { Temp (F) }\end{array}$ & $\begin{array}{r}\text { Max } \\
\text { Time }\end{array}$ & $\begin{array}{r}\text { Max } \\
\text { Temp (F) }\end{array}$ & $\begin{array}{r}\text { Daily } \\
\text { Mean (F) }\end{array}$ & $\begin{array}{l}\text { Daily } \\
\text { Mode }\end{array}$ & Notes \\
\hline $08 / 20 / 98$ & $07: 26$ & 61.0 & $14: 56$ & 66.8 & 63.5 & 62.0 & \\
\hline $08 / 21 / 98$ & $07: 26$ & 63.3 & $15: 56$ & 69.1 & 65.8 & 64.0 & \\
\hline $08 / 22 / 98$ & $07: 26$ & 64.1 & $14: 26$ & 69.7 & 66.3 & 64.0 & \\
\hline $08 / 23 / 98$ & $23: 56$ & 63.6 & $14: 26$ & 67.4 & 65.0 & 64.0 & \\
\hline $08 / 24 / 98$ & $09: 26$ & 61.0 & $14: 56$ & 65.6 & 63.2 & 64.0 & \\
\hline $08 / 25 / 98$ & $07: 56$ & 61.0 & $14: 26$ & 65.3 & 63.1 & 63.0 & \\
\hline $08 / 26 / 98$ & $06: 56$ & 61.6 & $14: 56$ & 66.8 & 63.8 & 62.0 & \\
\hline $08 / 27 / 98$ & $08: 56$ & 60.7 & $14: 26$ & 65.6 & 63.1 & 63.0 & \\
\hline $08 / 28 / 98$ & $06: 56$ & 60.7 & $15: 56$ & 66.8 & 63.6 & 61.0 & \\
\hline $08 / 29 / 98$ & $06: 26$ & 63.0 & $14: 56$ & 70.3 & 66.0 & 64.0 & \\
\hline $08 / 30 / 98$ & $06: 56$ & 63.0 & $15: 26$ & 69.7 & 65.9 & 63.0 & \\
\hline $08 / 31 / 98$ & $07: 26$ & 63.0 & $14: 26$ & 69.1 & 65.7 & 63.0 & \\
\hline $09 / 01 / 98$ & $06: 26$ & 63.3 & $15: 56$ & 69.4 & 66.1 & 64.0 & \\
\hline $09 / 02 / 98$ & $06: 56$ & 64.4 & $16: 56$ & 70.9 & 67.0 & 65.0 & \\
\hline $09 / 03 / 98$ & $08: 56$ & 63.6 & $15: 26$ & 70.3 & 66.6 & 64.0 & \\
\hline $09 / 04 / 98$ & $07: 26$ & 64.1 & $15: 26$ & 70.3 & 66.9 & 65.0 & \\
\hline $09 / 05 / 98$ & $06: 56$ & 64.1 & $14: 26$ & 69.4 & 66.4 & 65.0 & \\
\hline 09/06/98 & $07: 26$ & 62.4 & $14: 56$ & 68.2 & 65.0 & 64.0 & \\
\hline $09 / 07 / 98$ & $06: 56$ & 62.1 & $13: 56$ & 65.6 & 63.9 & 65.0 & \\
\hline $09 / 08 / 98$ & $06: 56$ & 62.7 & $15: 56$ & 66.8 & 64.6 & 66.0 & \\
\hline 09/09/98 & $22: 56$ & 61.0 & $01: 26$ & 65.0 & 62.9 & 62.0 & \\
\hline $09 / 10 / 98$ & $08: 26$ & 59.6 & $16: 26$ & 61.8 & 60.4 & 60.0 & \\
\hline $09 / 11 / 98$ & $08: 26$ & 58.1 & $13: 56$ & 61.0 & 59.6 & 60.0 & \\
\hline $09 / 12 / 98$ & $07: 26$ & 57.9 & $14: 56$ & 61.6 & 59.8 & 60.0 & \\
\hline $09 / 13 / 98$ & $07: 56$ & 59.0 & $15: 26$ & 63.0 & 61.0 & 60.0 & \\
\hline $09 / 14 / 98$ & $06: 56$ & 59.6 & $14: 26$ & 63.3 & 61.4 & 62.0 & \\
\hline $09 / 15 / 98$ & $07: 56$ & 60.4 & $14: 56$ & 64.1 & 62.3 & 63.0 & \\
\hline 09/16/98 & $01: 26$ & 62.7 & $14: 56$ & 66.5 & 64.5 & 63.0 & \\
\hline $09 / 17 / 98$ & $23: 56$ & 62.4 & $15: 26$ & 65.9 & 64.0 & 64.0 & \\
\hline $09 / 18 / 98$ & $23: 30$ & 59.8 & $13: 30$ & 63.0 & 60.2 & 62.0 & \\
\hline $09 / 19 / 98$ & 08:00 & 58.4 & $14: 00$ & 60.4 & 58.9 & 58.0 & \\
\hline 09/20/98 & 08:00 & 57.6 & $18: 00$ & 59.0 & 57.7 & 59.0 & \\
\hline $09 / 21 / 98$ & 09:00 & 55.9 & $00: 30$ & 58.4 & 56.9 & 56.0 & \\
\hline $09 / 22 / 98$ & 08:00 & 55.6 & $13: 00$ & 57.6 & 57.2 & 57.0 & \\
\hline $09 / 23 / 98$ & 07:00 & 56.7 & $13: 30$ & 59.3 & 58.2 & 58.0 & \\
\hline $09 / 24 / 98$ & 07:00 & 57.3 & $15: 00$ & 59.6 & 58.4 & 58.0 & \\
\hline $09 / 25 / 98$ & 23:00 & 57.9 & $14: 30$ & 59.3 & 57.7 & 57.0 & \\
\hline $09 / 26 / 98$ & 09:00 & 56.5 & 01:00 & 57.6 & 56.3 & 57.0 & \\
\hline $09 / 27 / 98$ & 08:00 & 54.8 & 00:00 & 56.5 & 55.7 & 56.0 & \\
\hline $09 / 28 / 98$ & $09: 30$ & 54.8 & $14: 30$ & 56.7 & 55.9 & 56.0 & \\
\hline
\end{tabular}


Summary of Daily Temperature Values for the Continuous Instream Monitor Placed in Lower Coppei Creek, 1998.

\begin{tabular}{|c|c|c|c|c|c|c|c|}
\hline Date & $\begin{array}{c}\text { Min } \\
\text { Time }\end{array}$ & $\begin{array}{r}\text { Min } \\
\text { Temp (F) }\end{array}$ & $\begin{array}{r}\text { Max } \\
\text { Time }\end{array}$ & $\begin{array}{r}\text { Max } \\
\text { Temp (F) }\end{array}$ & $\begin{array}{r}\text { Daily } \\
\text { Mean (F) }\end{array}$ & $\begin{array}{l}\text { Daily } \\
\text { Mode }\end{array}$ & Notes \\
\hline $09 / 29 / 98$ & 08:00 & 55.1 & $15: 30$ & 57.0 & 56.2 & 56.0 & \\
\hline 09/30/98 & 08:30 & 55.1 & $13: 30$ & 57.3 & 56.5 & 56.0 & \\
\hline $10 / 01 / 98$ & 08:00 & 55.6 & $16: 00$ & 57.6 & 56.1 & 57.0 & \\
\hline $10 / 02 / 98$ & $23: 30$ & 54.5 & 13:00 & 56.7 & 54.6 & 53.0 & \\
\hline $10 / 03 / 98$ & $22: 30$ & 52.3 & $00: 30$ & 54.5 & 52.7 & 52.0 & \\
\hline $10 / 04 / 98$ & 08:00 & 51.4 & $16: 00$ & 53.1 & 51.3 & 50.0 & \\
\hline $10 / 05 / 98$ & 08:30 & 49.6 & $00: 30$ & 51.7 & 50.4 & 51.0 & \\
\hline $10 / 06 / 98$ & 08:00 & 49.5 & 23:00 & 51.4 & 51.2 & 51.0 & \\
\hline $10 / 07 / 98$ & 07:00 & 51.2 & $16: 30$ & 53.1 & 52.9 & 53.0 & \\
\hline $10 / 08 / 98$ & 07:00 & 52.8 & $16: 00$ & 54.0 & 52.9 & 52.0 & \\
\hline $10 / 09 / 98$ & 08:30 & 51.7 & 02:00 & 53.1 & 52.1 & 53.0 & \\
\hline $10 / 10 / 98$ & $22: 30$ & 50.9 & 01:00 & 52.6 & 50.1 & 48.0 & \\
\hline $10 / 11 / 98$ & $10: 00$ & 47.8 & 00:00 & 50.9 & 48.7 & 48.0 & \\
\hline $10 / 12 / 98$ & 08:30 & 47.8 & $23: 00$ & 49.8 & 49.7 & 49.0 & \\
\hline $10 / 13 / 98$ & 01:00 & 49.8 & $20: 00$ & 52.6 & 51.9 & 52.0 & \\
\hline $10 / 14 / 98$ & $22: 00$ & 50.1 & $14: 30$ & 52.6 & 50.5 & 49.0 & \\
\hline $10 / 15 / 98$ & $22: 30$ & 48.1 & 01:00 & 50.1 & 47.9 & 46.0 & \\
\hline $10 / 16 / 98$ & 20:00 & 45.9 & $00: 30$ & 48.1 & 46.0 & 45.0 & \\
\hline $10 / 17 / 98$ & 08:30 & 44.5 & 23:00 & 46.4 & 46.4 & 47.0 & \\
\hline $10 / 18 / 98$ & 01:00 & 46.7 & $14: 00$ & 48.4 & 46.3 & 48.0 & \\
\hline $10 / 19 / 98$ & $10: 30$ & 44.5 & 00:00 & 47.5 & 44.6 & 43.0 & \\
\hline $10 / 20 / 98$ & 08:00 & 43.1 & 01:00 & 44.8 & 43.5 & 43.0 & \\
\hline $10 / 21 / 98$ & 09:30 & 42.5 & 01:00 & 43.9 & 43.7 & 44.0 & \\
\hline $10 / 22 / 98$ & 09:00 & 43.1 & $22: 30$ & 44.5 & 44.5 & 44.0 & \\
\hline $10 / 23 / 98$ & 09:00 & 44.5 & $22: 00$ & 46.2 & 45.9 & 46.0 & \\
\hline $10 / 24 / 98$ & 09:00 & 45.6 & $23: 30$ & 46.7 & 46.8 & 47.0 & \\
\hline $10 / 25 / 98$ & 00:30 & 46.7 & $17: 00$ & 48.9 & 48.4 & 48.0 & \\
\hline $10 / 26 / 98$ & 09:30 & 48.1 & 00:00 & 49.2 & 47.8 & 47.0 & \\
\hline $10 / 27 / 98$ & 09:00 & 46.7 & 06:00 & $00: 30$ & 48.1 & 48.0 & \\
\hline $10 / 28 / 98$ & 09:00 & 47.5 & $14: 00$ & 48.6 & 48.0 & 48.0 & monitor removed $14: 30 \mathrm{hrs}$. \\
\hline
\end{tabular}




\section{Summary of Daily Temperature Values and Flows for the Continuous Instream Monitor Placed at Touchet Gun Club, Lower Touchet River, 1998}

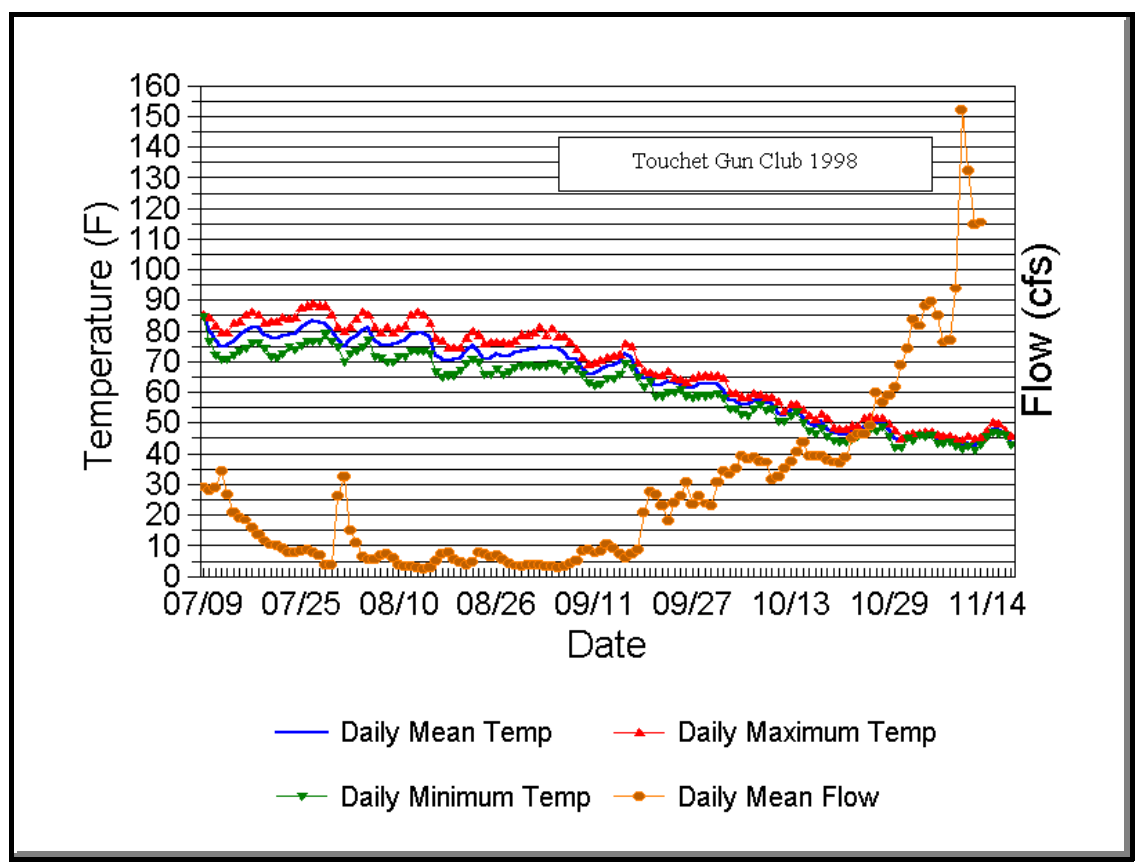

Summary of Daily Temperature Values and Flows for the Continuous Instream Monitor Placed at Touchet Gunclub, Lower Touchet River, 1998.

\begin{tabular}{|c|c|c|c|c|c|c|c|}
\hline Date & $\begin{array}{r}\text { Min } \\
\text { Time }\end{array}$ & $\begin{array}{r}\text { Min } \\
\text { Temp (F) } \\
\end{array}$ & $\begin{array}{r}\text { Max } \\
\text { Time } \\
\end{array}$ & $\begin{array}{r}\text { Max } \\
\text { Temp (F) } \\
\end{array}$ & $\begin{array}{r}\text { Daily Mean } \\
\text { Temp (F) }\end{array}$ & $\begin{array}{r}\text { Flow } \\
\text { (cfs) }\end{array}$ & Notes \\
\hline $07 / 02$ & & & & & & 14.1 & \\
\hline 07/09 & 08:00 & 84.8 & 08:00 & 85.5 & 85.5 & 32.9 & monitor installed $16: 00 \mathrm{hrs}$. \\
\hline $07 / 10$ & $12: 00$ & 76.6 & $12: 00$ & 84.8 & 80.9 & & \\
\hline $07 / 11$ & 08:00 & 72.1 & $12: 00$ & 82.1 & 76.9 & & \\
\hline $07 / 12$ & 08:00 & 70.5 & 08:00 & 79.6 & 75.0 & & \\
\hline $07 / 13$ & 08:00 & 70.5 & 08:00 & 79.6 & 75.3 & & \\
\hline $07 / 14$ & 08:00 & 72.1 & 08:00 & 82.8 & 76.9 & & \\
\hline $07 / 15$ & 08:00 & 73.2 & 08:00 & 83.5 & 78.4 & & \\
\hline $07 / 16$ & 08:00 & 74.3 & 08:00 & 85.5 & 80.0 & & \\
\hline $07 / 17$ & 08:00 & 76.0 & 08:00 & 86.2 & 81.3 & & \\
\hline $07 / 18$ & 08:00 & 76.0 & 08:00 & 85.5 & 81.1 & & \\
\hline $07 / 19$ & 08:00 & 74.3 & 08:00 & 82.8 & 79.0 & & \\
\hline $07 / 20$ & 08:00 & 71.5 & 08:00 & 83.5 & 77.9 & 13.1 & \\
\hline $07 / 21$ & 08:00 & 71.0 & 08:00 & 83.5 & 77.5 & & \\
\hline $07 / 22$ & 08:00 & 72.6 & 08:00 & 84.8 & 78.6 & & \\
\hline
\end{tabular}


Summary of Daily Temperature Values and Flows for the Continuous Instream Monitor Placed at Touchet Gunclub, Lower Touchet River, 1998.

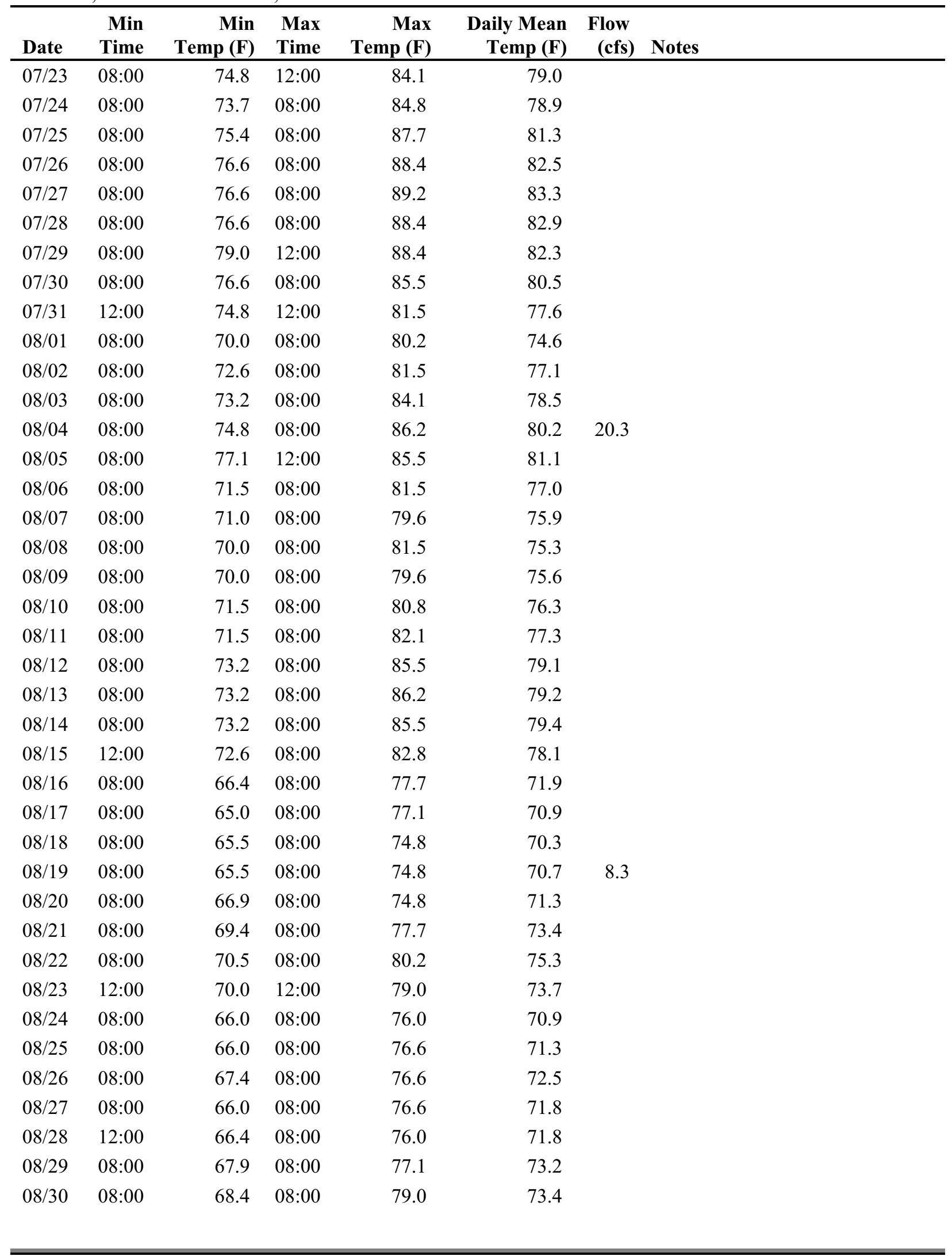


Summary of Daily Temperature Values and Flows for the Continuous Instream Monitor Placed at Touchet Gunclub, Lower Touchet River, 1998.

\begin{tabular}{|c|c|c|c|c|c|c|}
\hline Date & $\begin{array}{l}\text { Min } \\
\text { Time }\end{array}$ & $\begin{array}{r}\text { Min } \\
\text { Temp (F) }\end{array}$ & $\begin{array}{c}\text { Max } \\
\text { Time }\end{array}$ & $\begin{array}{r}\text { Max } \\
\text { Temp (F) }\end{array}$ & $\begin{array}{r}\text { Daily Mean } \\
\text { Temp (F) }\end{array}$ & $\begin{array}{l}\text { Flow } \\
\text { (cfs) Notes }\end{array}$ \\
\hline $08 / 31$ & 08:00 & 68.9 & 08:00 & 79.0 & 74.0 & \\
\hline 09/01 & 08:00 & 68.4 & 08:00 & 79.6 & 74.2 & 2.5 \\
\hline $09 / 02$ & $12: 00$ & 68.4 & 08:00 & 81.5 & 74.8 & \\
\hline $09 / 03$ & 08:00 & 68.4 & 08:00 & 79.0 & 74.3 & \\
\hline 09/04 & 08:00 & 69.4 & 08:00 & 80.8 & 74.9 & \\
\hline $09 / 05$ & 08:00 & 68.9 & 08:00 & 78.4 & 74.4 & \\
\hline 09/06 & 08:00 & 66.9 & 08:00 & 78.4 & 73.0 & \\
\hline 09/07 & $12: 00$ & 68.9 & $12: 00$ & 76.6 & 71.0 & \\
\hline 09/08 & 08:00 & 67.4 & 04:00 & 74.3 & 70.6 & \\
\hline 09/09 & $12: 00$ & 66.0 & $12: 00$ & 71.5 & 68.1 & \\
\hline $09 / 10$ & 08:00 & 63.2 & 08:00 & 69.4 & 66.0 & \\
\hline $09 / 11$ & 08:00 & 62.2 & 08:00 & 70.0 & 66.4 & \\
\hline $09 / 12$ & 08:00 & 62.7 & 08:00 & 70.5 & 67.1 & \\
\hline $09 / 13$ & 08:00 & 64.5 & 08:00 & 71.5 & 68.5 & \\
\hline $09 / 14$ & 08:00 & 64.5 & 08:00 & 72.1 & 69.0 & \\
\hline $09 / 15$ & $12: 00$ & 66.0 & 08:00 & 72.6 & 69.9 & \\
\hline $09 / 16$ & $12: 00$ & 69.4 & 08:00 & 76.0 & 72.7 & \\
\hline $09 / 17$ & $12: 00$ & 67.9 & $12: 00$ & 75.4 & 71.2 & 6.9 \\
\hline $09 / 18$ & $12: 00$ & 65.0 & $12: 00$ & 70.0 & 67.0 & \\
\hline $09 / 19$ & 08:00 & 61.8 & 08:00 & 66.9 & 64.5 & \\
\hline $09 / 20$ & $12: 00$ & 63.6 & $12: 00$ & 66.4 & 64.8 & \\
\hline $09 / 21$ & 08:00 & 58.3 & 08:00 & 66.0 & 62.4 & \\
\hline $09 / 22$ & $12: 00$ & 58.8 & 08:00 & 66.0 & 62.9 & \\
\hline $09 / 23$ & $12: 00$ & 60.0 & 08:00 & 66.9 & 63.7 & \\
\hline $09 / 24$ & 08:00 & 60.0 & 08:00 & 65.0 & 63.4 & \\
\hline $09 / 25$ & $12: 00$ & 60.9 & $12: 00$ & 64.5 & 62.5 & \\
\hline $09 / 26$ & $12: 00$ & 58.8 & 08:00 & 63.6 & 61.3 & \\
\hline $09 / 27$ & 08:00 & 57.9 & 08:00 & 65.0 & 61.4 & \\
\hline $09 / 28$ & $12: 00$ & 58.8 & 08:00 & 65.5 & 62.6 & \\
\hline $09 / 29$ & $12: 00$ & 58.8 & 08:00 & 66.0 & 62.7 & \\
\hline $09 / 30$ & $12: 00$ & 59.2 & 08:00 & 65.5 & 62.7 & \\
\hline $10 / 01$ & 08:00 & 59.6 & 08:00 & 66.0 & 62.9 & \\
\hline $10 / 02$ & $12: 00$ & 57.9 & $12: 00$ & 65.0 & 61.0 & \\
\hline $10 / 03$ & $12: 00$ & 54.7 & $12: 00$ & 60.0 & 57.4 & \\
\hline $10 / 04$ & 08:00 & 54.3 & 08:00 & 60.0 & 57.1 & \\
\hline $10 / 05$ & $12: 00$ & 52.7 & 08:00 & 58.8 & 56.2 & \\
\hline $10 / 06$ & $12: 00$ & 52.3 & 08:00 & 58.3 & 55.9 & 34.4 \\
\hline $10 / 07$ & 08:00 & 54.3 & 08:00 & 60.0 & 57.2 & \\
\hline $10 / 08$ & $12: 00$ & 55.9 & $12: 00$ & 59.6 & 57.8 & \\
\hline
\end{tabular}


Summary of Daily Temperature Values and Flows for the Continuous Instream Monitor Placed at Touchet Gunclub, Lower Touchet River, 1998.

\begin{tabular}{|c|c|c|c|c|c|c|c|}
\hline Date & $\begin{array}{l}\text { Min } \\
\text { Time }\end{array}$ & $\begin{array}{r}\text { Min } \\
\text { Temp (F) }\end{array}$ & $\begin{array}{c}\text { Max } \\
\text { Time }\end{array}$ & $\begin{array}{r}\text { Max } \\
\text { Temp (F) }\end{array}$ & $\begin{array}{r}\text { Daily Mean } \\
\text { Temp (F) }\end{array}$ & $\begin{array}{l}\text { Flow } \\
\text { (cfs) }\end{array}$ & Notes \\
\hline $10 / 09$ & 08:00 & 53.9 & 08:00 & 58.3 & 56.5 & & \\
\hline $10 / 10$ & 08:00 & 54.3 & 08:00 & 58.3 & 56.3 & & \\
\hline $10 / 11$ & $12: 00$ & 50.4 & $12: 00$ & 57.1 & 53.2 & & \\
\hline $10 / 12$ & $12: 00$ & 50.4 & 08:00 & 53.9 & 52.3 & & \\
\hline $10 / 13$ & 08:00 & 52.3 & 08:00 & 56.3 & 54.0 & & \\
\hline $10 / 14$ & $12: 00$ & 53.5 & $12: 00$ & 56.3 & 55.0 & & \\
\hline $10 / 15$ & $12: 00$ & 50.1 & $12: 00$ & 54.3 & 52.2 & & \\
\hline $10 / 16$ & $12: 00$ & 47.2 & $12: 00$ & 52.7 & 50.3 & & \\
\hline $10 / 17$ & $12: 00$ & 46.5 & $12: 00$ & 51.2 & 48.6 & & \\
\hline $10 / 18$ & $12: 00$ & 48.2 & 08:00 & 53.1 & 50.6 & & \\
\hline $10 / 19$ & $12: 00$ & 45.4 & $12: 00$ & 51.6 & 48.4 & & \\
\hline $10 / 20$ & $12: 00$ & 44.1 & 08:00 & 48.6 & 46.8 & & \\
\hline $10 / 21$ & $12: 00$ & 43.7 & 08:00 & 48.2 & 46.4 & & \\
\hline $10 / 22$ & $12: 00$ & 43.7 & 08:00 & 48.2 & 46.1 & & \\
\hline $10 / 23$ & $12: 00$ & 44.7 & 08:00 & 49.3 & 47.2 & 39.8 & \\
\hline $10 / 24$ & $12: 00$ & 45.4 & $12: 00$ & 49.0 & 47.2 & & \\
\hline $10 / 25$ & $12: 00$ & 46.8 & 08:00 & 51.9 & 49.0 & & \\
\hline $10 / 26$ & 08:00 & 47.5 & 08:00 & 52.3 & 50.1 & & \\
\hline $10 / 27$ & $12: 00$ & 47.2 & 08:00 & 51.6 & 49.9 & & \\
\hline $10 / 28$ & $12: 00$ & 48.6 & $12: 00$ & 51.6 & 50.5 & & \\
\hline $10 / 29$ & $12: 00$ & 45.4 & $12: 00$ & 50.1 & 47.9 & & \\
\hline $10 / 30$ & $12: 00$ & 42.1 & $12: 00$ & 47.9 & 45.0 & & \\
\hline $10 / 31$ & $12: 00$ & 42.1 & $12: 00$ & 45.1 & 44.1 & & \\
\hline $11 / 01$ & 08:00 & 45.1 & 08:00 & 46.5 & 45.5 & & \\
\hline $11 / 02$ & $12: 00$ & 44.1 & 08:00 & 46.8 & 45.7 & & \\
\hline $11 / 03$ & 08:00 & 45.8 & 08:00 & 46.8 & 46.4 & & \\
\hline $11 / 04$ & 08:00 & 45.4 & 08:00 & 47.2 & 46.4 & 57.6 & \\
\hline $11 / 05$ & 08:00 & 46.1 & $12: 00$ & 47.2 & 46.5 & & \\
\hline $11 / 06$ & $12: 00$ & 43.4 & $12: 00$ & 46.5 & 45.4 & & \\
\hline $11 / 07$ & $12: 00$ & 43.4 & $12: 00$ & 46.1 & 44.5 & & \\
\hline $11 / 08$ & 08:00 & 43.7 & 08:00 & 46.1 & 44.7 & & \\
\hline $11 / 09$ & $12: 00$ & 42.4 & 08:00 & 45.1 & 44.1 & & \\
\hline $11 / 10$ & $12: 00$ & 41.4 & $12: 00$ & 44.7 & 43.2 & & \\
\hline $11 / 11$ & 08:00 & 42.4 & 08:00 & 45.8 & 43.6 & & \\
\hline $11 / 12$ & $12: 00$ & 41.1 & $12: 00$ & 45.1 & 42.7 & & \\
\hline $11 / 13$ & $12: 00$ & 43.0 & 08:00 & 45.4 & 44.2 & & \\
\hline $11 / 14$ & 08:00 & 45.4 & 08:00 & 47.5 & 46.1 & & \\
\hline $11 / 15$ & 08:00 & 46.8 & 08:00 & 50.4 & 48.1 & & \\
\hline $11 / 16$ & $12: 00$ & 46.5 & $12: 00$ & 50.1 & 48.1 & & \\
\hline
\end{tabular}


Summary of Daily Temperature Values and Flows for the Continuous Instream Monitor Placed at Touchet Gunclub, Lower Touchet River, 1998.

\begin{tabular}{lrrrrrl}
\hline Date & $\begin{array}{r}\text { Min } \\
\text { Time }\end{array}$ & $\begin{array}{r}\text { Min } \\
\text { Temp (F) }\end{array}$ & $\begin{array}{r}\text { Max } \\
\text { Time }\end{array}$ & $\begin{array}{r}\text { Max } \\
\text { Temp (F) }\end{array}$ & $\begin{array}{r}\text { Daily Mean } \\
\text { Temp (F) }\end{array}$ & $\begin{array}{r}\text { Flow } \\
(\mathbf{c f s})\end{array}$ \\
\hline $11 / 17$ & $12: 00$ & 45.8 & $12: 00$ & 47.5 & 46.7 & \\
$11 / 18$ & $08: 00$ & 43.0 & $12: 00$ & 46.1 & 44.2 & monitor removed 12:00 hrs \\
\hline
\end{tabular}




\section{Summary of Daily Temperature Values for the Continuous Instream Monitor Placed in the North Fork Touchet River, Just Upstream From Jim Creek, 1998}

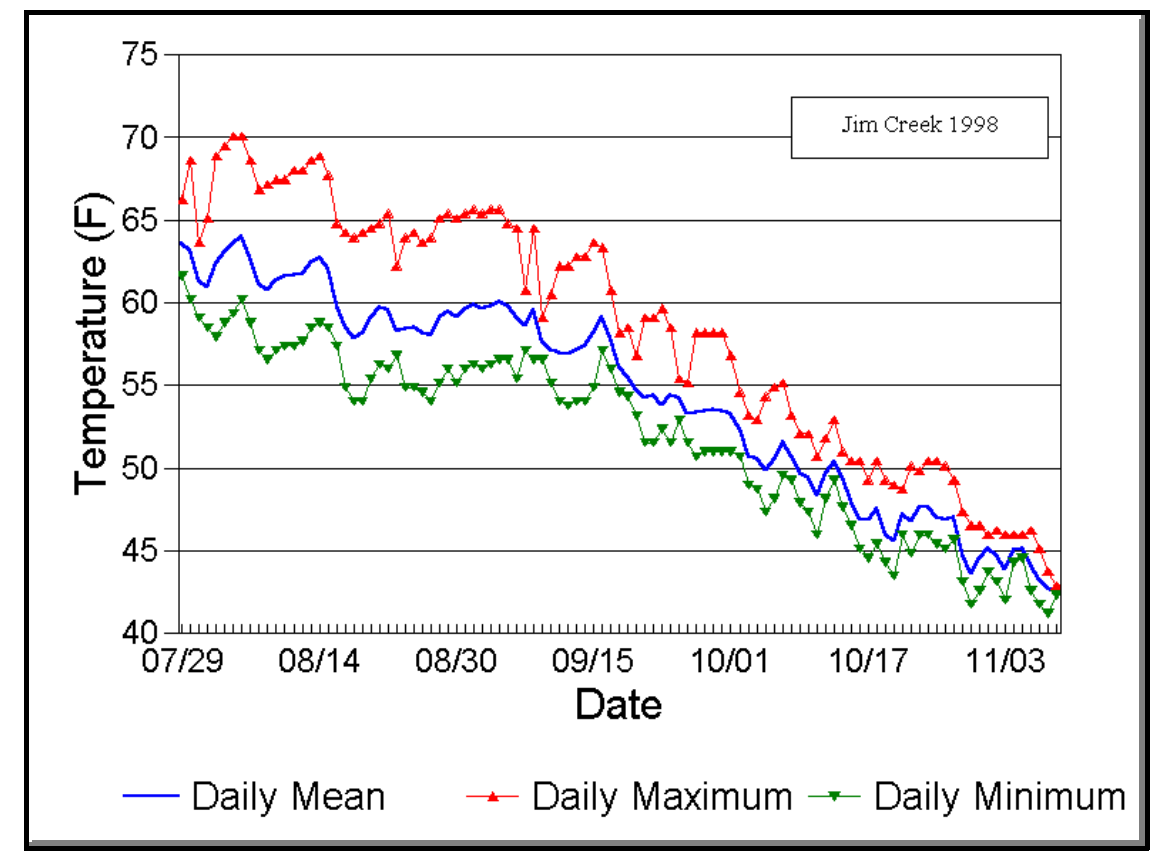

Summary of Daily Temperature Values for the Continuous Instream Monitor Placed in the North Fork Touchet River, Just Upstream from Jim Creek, 1988.

\begin{tabular}{lrrrrrrl}
\hline Date & $\begin{array}{r}\text { Min } \\
\text { Time }\end{array}$ & $\begin{array}{r}\text { Min } \\
\text { Temp (F) }\end{array}$ & $\begin{array}{r}\text { Max } \\
\text { Time }\end{array}$ & $\begin{array}{r}\text { Max } \\
\text { Temp (F) }\end{array}$ & $\begin{array}{r}\text { Daily } \\
\text { Mean (F) }\end{array}$ & $\begin{array}{r}\text { Daily } \\
\text { Mode }\end{array}$ & Notes \\
\hline $07 / 29 / 98$ & $23: 26$ & 61.6 & $14: 56$ & 66.3 & 63.6 & 62.0 & monitor installed 14:56 hrs. \\
$07 / 30 / 98$ & $05: 56$ & 60.2 & $14: 56$ & 68.6 & 63.2 & 61.0 & \\
$07 / 31 / 98$ & $23: 26$ & 59.1 & $12: 56$ & 63.6 & 61.4 & 61.0 & \\
$08 / 01 / 98$ & $01: 56$ & 58.5 & $15: 56$ & 65.1 & 60.9 & 59.0 & \\
$08 / 02 / 98$ & $05: 26$ & 57.9 & $14: 56$ & 68.9 & 62.4 & 58.0 & \\
$08 / 03 / 98$ & $06: 26$ & 58.8 & $14: 56$ & 69.5 & 63.1 & 59.0 & \\
$08 / 04 / 98$ & $05: 26$ & 59.4 & $14: 56$ & 70.1 & 63.6 & 60.0 & \\
$08 / 05 / 98$ & $04: 56$ & 60.2 & $14: 56$ & 70.1 & 64.0 & 61.0 & \\
$08 / 06 / 98$ & $06: 56$ & 58.8 & $14: 56$ & 68.6 & 62.7 & 61.0 & \\
$08 / 07 / 98$ & $06: 56$ & 57.1 & $14: 56$ & 66.8 & 61.2 & 59.0 & \\
$08 / 08 / 98$ & $05: 56$ & 56.6 & $14: 56$ & 67.1 & 60.8 & 57.0 & \\
$08 / 09 / 98$ & $06: 26$ & 57.1 & $14: 56$ & 67.4 & 61.4 & 57.0 & \\
$08 / 10 / 98$ & $07: 26$ & 57.4 & $14: 56$ & 67.4 & 61.6 & 58.0 & \\
$08 / 11 / 98$ & $06: 56$ & 57.4 & $14: 26$ & 68.0 & 61.7 & 58.0 & \\
$08 / 12 / 98$ & $06: 26$ & 57.7 & $14: 29$ & 68.0 & 61.8 & 58.0 & \\
$08 / 13 / 98$ & $05: 59$ & 58.5 & $14: 59$ & 68.6 & 62.5 & 59.0 &
\end{tabular}


Summary of Daily Temperature Values for the Continuous Instream Monitor Placed in the North Fork Touchet River, Just Upstream from Jim Creek, 1988.

\begin{tabular}{lrrrrrr}
\hline Date & $\begin{array}{r}\text { Min } \\
\text { Time }\end{array}$ & $\begin{array}{r}\text { Min } \\
\text { Temp (F) }\end{array}$ & $\begin{array}{r}\text { Max } \\
\text { Time }\end{array}$ & $\begin{array}{r}\text { Max } \\
\text { Temp (F) }\end{array}$ & $\begin{array}{r}\text { Daily } \\
\text { Mean (F) }\end{array}$ & $\begin{array}{c}\text { Daily } \\
\text { Mode }\end{array}$ Notes \\
\hline $08 / 14 / 98$ & $05: 29$ & 58.8 & $14: 59$ & 68.9 & 62.7 & 59.0 \\
$08 / 15 / 98$ & $07: 29$ & 58.5 & $14: 29$ & 67.7 & 62.0 & 60.0 \\
$08 / 16 / 98$ & $05: 59$ & 57.4 & $14: 59$ & 64.8 & 59.8 & 58.0 \\
$08 / 17 / 98$ & $06: 59$ & 54.9 & $14: 59$ & 64.2 & 58.5 & 57.0 \\
$08 / 18 / 98$ & $05: 59$ & 54.0 & $14: 29$ & 63.9 & 57.9 & 55.0 \\
$08 / 19 / 98$ & $06: 29$ & 54.0 & $14: 59$ & 64.2 & 58.2 & 55.0 \\
$08 / 20 / 98$ & $06: 59$ & 55.4 & $14: 59$ & 64.5 & 59.1 & 56.0 \\
$08 / 21 / 98$ & $06: 29$ & 56.3 & $14: 59$ & 64.8 & 59.8 & 58.0 \\
$08 / 22 / 98$ & $05: 59$ & 56.0 & $14: 29$ & 65.4 & 59.6 & 57.0 \\
$08 / 23 / 98$ & $22: 59$ & 56.8 & $13: 59$ & 62.2 & 58.3 & 57.0 \\
$08 / 24 / 98$ & $05: 59$ & 54.9 & $14: 59$ & 63.9 & 58.5 & 55.0 \\
$08 / 25 / 98$ & $06: 59$ & 54.9 & $14: 29$ & 64.2 & 58.6 & 55.0 \\
$08 / 26 / 98$ & $05: 59$ & 54.6 & $14: 29$ & 63.6 & 58.2 & 55.0 \\
$08 / 27 / 98$ & $06: 29$ & 54.0 & $14: 29$ & 63.9 & 58.0 & 55.0 \\
$08 / 28 / 98$ & $06: 29$ & 55.2 & $14: 59$ & 65.1 & 59.2 & 56.0 \\
$08 / 29 / 98$ & $05: 59$ & 56.0 & $14: 29$ & 65.4 & 59.5 & 57.0 \\
$08 / 30 / 98$ & $06: 29$ & 55.2 & $14: 29$ & 65.1 & 59.1 & 56.0 \\
$08 / 31 / 98$ & $06: 29$ & 56.0 & $14: 59$ & 65.4 & 59.6 & 57.0 \\
$09 / 01 / 98$ & $06: 29$ & 56.3 & $14: 29$ & 65.7 & 59.9 & 57.0 \\
$09 / 02 / 98$ & $07: 29$ & 56.0 & $14: 29$ & 65.4 & 59.7 & 57.0 \\
& & & & & & \\
\hline & & & & &
\end{tabular}


Summary of Daily Temperature Values for the Continuous Instream Monitor Placed in the North Fork Touchet River, Just Upstream from Jim Creek, 1988.

\begin{tabular}{|c|c|c|c|c|c|c|}
\hline Date & $\begin{array}{r}\text { Min } \\
\text { Time }\end{array}$ & $\begin{array}{r}\text { Min } \\
\text { Temp (F) } \\
\end{array}$ & $\begin{array}{r}\text { Max } \\
\text { Time }\end{array}$ & $\begin{array}{r}\text { Max } \\
\text { Temp (F) } \\
\end{array}$ & $\begin{array}{r}\text { Daily } \\
\text { Mean (F) }\end{array}$ & $\begin{array}{l}\text { Daily } \\
\text { Mode Notes }\end{array}$ \\
\hline $09 / 03 / 98$ & $05: 59$ & 56.3 & $14: 29$ & 65.7 & 59.9 & 57.0 \\
\hline $09 / 04 / 98$ & 06:59 & 56.6 & $14: 29$ & 65.7 & 60.0 & 57.0 \\
\hline 09/05/98 & $06: 29$ & 56.6 & $14: 29$ & 64.8 & 59.9 & 57.0 \\
\hline $09 / 06 / 98$ & $07: 29$ & 55.4 & $14: 29$ & 64.5 & 59.1 & 56.0 \\
\hline 09/07/98 & 02:29 & 57.1 & $14: 29$ & 60.8 & 58.6 & 57.0 \\
\hline 09/08/98 & $06: 59$ & 56.6 & $14: 29$ & 64.5 & 59.6 & 57.0 \\
\hline 09/09/98 & $23: 29$ & 56.6 & $15: 59$ & 59.1 & 57.7 & 57.0 \\
\hline $09 / 10 / 98$ & $23: 55$ & 55.2 & $14: 29$ & 60.5 & 57.2 & 56.0 \\
\hline $09 / 11 / 98$ & $07: 55$ & 54.0 & $13: 55$ & 62.2 & 57.0 & 55.0 \\
\hline $09 / 12 / 98$ & $07: 25$ & 53.8 & $14: 55$ & 62.2 & 56.9 & 54.0 \\
\hline 09/13/98 & $08: 25$ & 54.0 & $14: 25$ & 62.8 & 57.1 & 55.0 \\
\hline 09/14/98 & $07: 25$ & 54.0 & $13: 55$ & 62.8 & 57.4 & 55.0 \\
\hline $09 / 15 / 98$ & $08: 25$ & 54.9 & $14: 25$ & 63.6 & 58.2 & 55.0 \\
\hline 09/16/98 & $07: 25$ & 57.1 & $13: 55$ & 63.4 & 59.1 & 57.0 \\
\hline 09/17/98 & $07: 25$ & 56.0 & $14: 25$ & 60.8 & 57.8 & 57.0 \\
\hline 09/18/98 & $08: 25$ & 54.6 & $14: 55$ & 58.2 & 56.1 & 55.0 \\
\hline 09/19/98 & $23: 25$ & 54.3 & $13: 25$ & 58.5 & 55.5 & 55.0 \\
\hline 09/20/98 & $23: 55$ & 53.2 & $14: 25$ & 56.8 & 54.8 & 54.0 \\
\hline $09 / 21 / 98$ & 07:55 & 51.5 & $13: 55$ & 59.1 & 54.3 & 52.0 \\
\hline $09 / 22 / 98$ & $07: 25$ & 51.5 & $14: 25$ & 59.1 & 54.4 & 52.0 \\
\hline
\end{tabular}


Summary of Daily Temperature Values for the Continuous Instream Monitor Placed in the North Fork Touchet River, Just Upstream from Jim Creek, 1988.

\begin{tabular}{lrrrrrr}
\hline Date & $\begin{array}{r}\text { Min } \\
\text { Time }\end{array}$ & $\begin{array}{r}\text { Min } \\
\text { Temp (F) }\end{array}$ & $\begin{array}{r}\text { Max } \\
\text { Time }\end{array}$ & $\begin{array}{r}\text { Max } \\
\text { Temp (F) }\end{array}$ & $\begin{array}{r}\text { Daily } \\
\text { Mean }(\mathbf{F})\end{array}$ & $\begin{array}{c}\text { Daily } \\
\text { Mode }\end{array}$ Notes \\
\hline $09 / 23 / 98$ & $07: 25$ & 52.4 & $13: 55$ & 59.6 & 53.8 & 53.0 \\
$09 / 24 / 98$ & $07: 55$ & 51.5 & $14: 25$ & 58.5 & 54.4 & 52.0 \\
$09 / 25 / 98$ & $23: 55$ & 52.9 & $14: 25$ & 55.4 & 54.2 & 54.0 \\
$09 / 26 / 98$ & $08: 25$ & 51.5 & $14: 55$ & 55.2 & 53.3 & 52.0 \\
$09 / 27 / 98$ & $07: 55$ & 50.7 & $13: 55$ & 58.2 & 53.4 & 51.0 \\
$09 / 28 / 98$ & $07: 25$ & 51.0 & $14: 25$ & 58.2 & 53.5 & 52.0 \\
$09 / 29 / 98$ & $07: 55$ & 51.0 & $14: 25$ & 58.2 & 53.5 & 52.0 \\
$09 / 30 / 98$ & $08: 25$ & 51.0 & $14: 25$ & 58.2 & 53.5 & 52.0 \\
$10 / 01 / 98$ & $08: 25$ & 51.0 & $14: 25$ & 56.8 & 53.3 & 51.0 \\
$10 / 02 / 98$ & $23: 55$ & 50.7 & $13: 55$ & 54.6 & 52.4 & 52.0 \\
$10 / 03 / 98$ & $07: 55$ & 49.0 & $14: 55$ & 53.2 & 50.8 & 50.0 \\
$10 / 04 / 98$ & $23: 55$ & 48.7 & $14: 55$ & 52.9 & 50.5 & 50.0 \\
$10 / 05 / 98$ & $07: 25$ & 47.4 & $14: 25$ & 54.3 & 49.9 & 48.0 \\
$10 / 06 / 98$ & $08: 25$ & 48.2 & $14: 25$ & 54.9 & 50.6 & 48.0 \\
$10 / 07 / 98$ & $00: 25$ & 49.6 & $14: 55$ & 55.2 & 51.6 & 50.0 \\
$10 / 08 / 98$ & $23: 55$ & 49.3 & $14: 25$ & 53.2 & 50.7 & 50.0 \\
$10 / 09 / 98$ & $07: 25$ & 47.9 & $14: 55$ & 52.1 & 49.7 & 49.0 \\
$10 / 10 / 98$ & $23: 55$ & 47.4 & $14: 25$ & 52.1 & 49.4 & 49.0 \\
$10 / 11 / 98$ & $06: 55$ & 46.0 & $15: 25$ & 50.7 & 48.3 & 50.0 \\
$10 / 12 / 98$ & $07: 55$ & 48.2 & $14: 55$ & 51.8 & 49.7 & 48.0 \\
& & & & & & \\
\hline & & & & &
\end{tabular}


Summary of Daily Temperature Values for the Continuous Instream Monitor Placed in the North Fork Touchet River, Just Upstream from Jim Creek, 1988.

\begin{tabular}{|c|c|c|c|c|c|c|c|}
\hline Date & $\begin{array}{r}\text { Min } \\
\text { Time }\end{array}$ & $\begin{array}{r}\text { Min } \\
\text { Temp (F) } \\
\end{array}$ & $\begin{array}{r}\text { Max } \\
\text { Time } \\
\end{array}$ & $\begin{array}{r}\text { Max } \\
\text { Temp (F) } \\
\end{array}$ & $\begin{array}{r}\text { Daily } \\
\text { Mean (F) } \\
\end{array}$ & $\begin{array}{l}\text { Daily } \\
\text { Mode }\end{array}$ & Notes \\
\hline $10 / 13 / 98$ & $02: 55$ & 49.3 & $14: 25$ & 52.9 & 50.4 & 50.0 & \\
\hline $10 / 14 / 98$ & $23: 55$ & 47.6 & $15: 25$ & 51.0 & 49.5 & 49.0 & \\
\hline $10 / 15 / 98$ & $23: 55$ & 46.5 & $13: 55$ & 50.4 & 48.0 & 47.0 & \\
\hline $10 / 16 / 98$ & 08:55 & 45.1 & $14: 25$ & 50.4 & 46.9 & 46.0 & \\
\hline $10 / 17 / 98$ & $06: 25$ & 44.6 & $16: 25$ & 49.3 & 46.9 & 45.0 & \\
\hline $10 / 18 / 98$ & $23: 55$ & 45.4 & $13: 55$ & 50.4 & 47.5 & 47.0 & \\
\hline $10 / 19 / 98$ & 07:55 & 44.3 & $13: 55$ & 49.3 & 46.0 & 45.0 & \\
\hline \multirow[t]{2}{*}{$10 / 20 / 98$} & 08:55 & 43.5 & $13: 55$ & 49.0 & 45.6 & 44.0 & \\
\hline & & & & & & & monitor malfunction $10 / 21 / 98$ \\
\hline $10 / 22 / 98$ & $23: 14$ & 46.0 & 13:44 & 48.7 & 47.3 & 48.0 & \\
\hline $10 / 23 / 98$ & $07: 14$ & 44.9 & 14:14 & 50.1 & 46.8 & 45.0 & \\
\hline $10 / 24 / 98$ & 04:44 & 46.0 & $15: 14$ & 49.9 & 47.6 & 46.0 & \\
\hline $10 / 25 / 98$ & 07:44 & 46.0 & $14: 14$ & 50.4 & 47.7 & 47.0 & \\
\hline $10 / 26 / 98$ & $06: 44$ & 45.4 & $14: 14$ & 50.4 & 47.0 & 46.0 & \\
\hline $10 / 27 / 98$ & $06: 14$ & 45.1 & $14: 14$ & 50.1 & 46.9 & 45.0 & \\
\hline $10 / 28 / 98$ & $07: 44$ & 45.7 & $13: 44$ & 49.3 & 47.1 & 47.0 & \\
\hline $10 / 29 / 98$ & 08:44 & 43.2 & $13: 44$ & 47.4 & 44.8 & 44.0 & \\
\hline $10 / 30 / 98$ & $07: 44$ & 41.8 & $14: 14$ & 46.5 & 43.6 & 42.0 & \\
\hline $10 / 31 / 98$ & $07: 14$ & 42.6 & $14: 44$ & 46.5 & 44.6 & 43.0 & \\
\hline $11 / 01 / 98$ & $23: 14$ & 43.7 & $15: 14$ & 46.0 & 45.2 & 45.0 & \\
\hline
\end{tabular}


Summary of Daily Temperature Values for the Continuous Instream Monitor Placed in the North Fork Touchet River, Just Upstream from Jim Creek, 1988.

\begin{tabular}{lrrrrrrl}
\hline Date & $\begin{array}{r}\text { Min } \\
\text { Time }\end{array}$ & $\begin{array}{r}\text { Min } \\
\text { Temp (F) }\end{array}$ & $\begin{array}{r}\text { Max } \\
\text { Time }\end{array}$ & $\begin{array}{r}\text { Max } \\
\text { Temp (F) }\end{array}$ & $\begin{array}{r}\text { Daily } \\
\text { Mean (F) }\end{array}$ & $\begin{array}{r}\text { Daily } \\
\text { Mode }\end{array}$ & Notes \\
\hline $11 / 02 / 98$ & $23: 44$ & 43.2 & $14: 44$ & 46.3 & 44.7 & 44.0 & \\
$11 / 03 / 98$ & $08: 14$ & 42.1 & $13: 14$ & 46.0 & 43.9 & 43.0 & \\
$11 / 04 / 98$ & $03: 44$ & 44.3 & $15: 14$ & 46.0 & 45.1 & 45.0 & \\
$11 / 05 / 98$ & $23: 44$ & 44.6 & $15: 14$ & 46.0 & 45.1 & 45.0 & \\
$11 / 06 / 98$ & $09: 14$ & 42.6 & $13: 44$ & 46.3 & 44.1 & 43.0 & \\
$11 / 07 / 98$ & $08: 14$ & 41.8 & $14: 14$ & 45.1 & 43.3 & 42.0 & \\
$11 / 08 / 98$ & $05: 44$ & 41.2 & $01: 14$ & 43.7 & 42.7 & 43.0 & \\
$11 / 09 / 98$ & $07: 44$ & 42.3 & $11: 14$ & 42.9 & 42.5 & 43.0 & monitor removed 11:14 hrs. \\
\hline
\end{tabular}




\section{Summary of Daily Temperature Values for the Continuous Instream Monitor Placed at Knotgrass Rd., Touchet River, 1998}

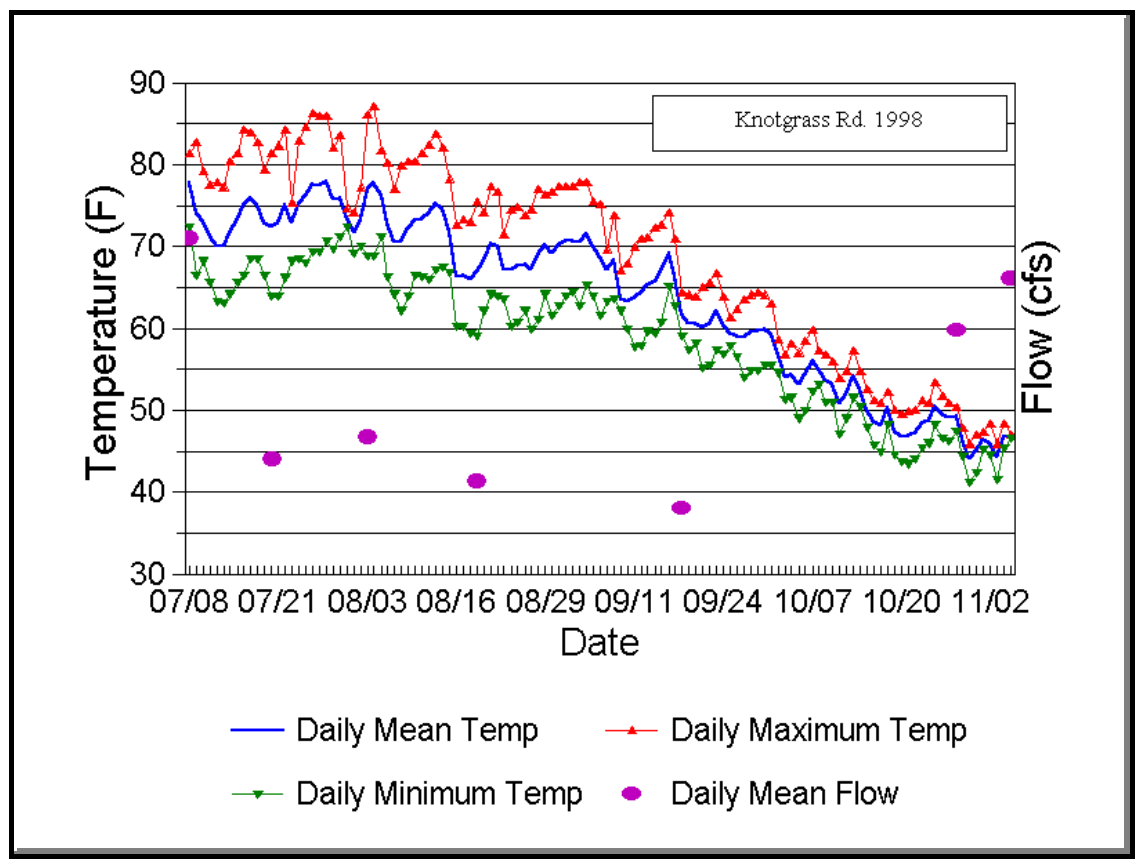

Summary of Daily Temperature Values for the Continuous Instream Monitor Placed at Knotgrass Road, Touchet River, 1988. Manual Flows were also measured at the same location.

\begin{tabular}{|c|c|c|c|c|c|c|c|c|}
\hline Date & $\begin{array}{c}\text { Min } \\
\text { Time } \\
\end{array}$ & $\begin{array}{r}\text { Min } \\
\text { Temp (F) } \\
\end{array}$ & $\begin{array}{r}\text { Max } \\
\text { Time }\end{array}$ & $\begin{array}{r}\text { Max } \\
\text { Temp (F) } \\
\end{array}$ & $\begin{array}{r}\text { Daily } \\
\text { Mean (F) }\end{array}$ & $\begin{array}{l}\text { Daily } \\
\text { Mode }\end{array}$ & $\begin{array}{r}\text { Flows } \\
\text { (cfs) }\end{array}$ & Notes \\
\hline $07 / 08 / 98$ & $11: 00$ & 72.4 & $17: 30$ & 81.4 & 77.7 & 81.0 & 71.0 & monitor installed \\
\hline $07 / 09 / 98$ & $07: 30$ & 66.5 & $16: 15$ & 82.7 & 74.0 & 82.0 & & $10: 45 \mathrm{hrs}$ \\
\hline 07/10/98 & 07:00 & 68.2 & $16: 15$ & 79.2 & 73.1 & 69.0 & & \\
\hline $07 / 11 / 98$ & $08: 15$ & 65.6 & $17: 15$ & 77.6 & 71.2 & 66.0 & & \\
\hline $07 / 12 / 98$ & 08:00 & 63.3 & $16: 30$ & 77.9 & 70.1 & 64.0 & & \\
\hline $07 / 13 / 98$ & $07: 30$ & 63.0 & $17: 15$ & 77.3 & 70.0 & 77.0 & & \\
\hline $07 / 14 / 98$ & 07:00 & 64.2 & $16: 45$ & 80.5 & 71.8 & 80.0 & & \\
\hline $07 / 15 / 98$ & $07: 45$ & 65.6 & $16: 15$ & 81.4 & 73.4 & 66.0 & & \\
\hline $07 / 16 / 98$ & $07: 15$ & 66.5 & $17: 15$ & 84.4 & 75.1 & 84.0 & & \\
\hline $07 / 17 / 98$ & 07:00 & 68.5 & $16: 45$ & 84.0 & 75.9 & 69.0 & & \\
\hline $07 / 18 / 98$ & $07: 45$ & 68.5 & $16: 00$ & 82.7 & 75.1 & 69.0 & & \\
\hline $07 / 19 / 98$ & $07: 45$ & 66.5 & $17: 00$ & 79.5 & 72.9 & 67.0 & & \\
\hline $07 / 20 / 98$ & $07: 45$ & 63.9 & $17: 11$ & 81.4 & 72.4 & 81.0 & 44.1 & \\
\hline $07 / 21 / 98$ & $07: 41$ & 63.9 & $17: 11$ & 82.4 & 73.0 & 64.0 & & \\
\hline $07 / 22 / 98$ & $07: 11$ & 66.2 & $17: 26$ & 84.4 & 75.1 & 84.0 & & \\
\hline $07 / 23 / 98$ & $07: 26$ & 68.2 & $16: 56$ & 75.4 & 72.9 & 75.0 & & \\
\hline $07 / 24 / 98$ & $07: 26$ & 68.5 & $16: 26$ & 83.0 & 75.3 & 69.0 & & \\
\hline
\end{tabular}


Summary of Daily Temperature Values for the Continuous Instream Monitor Placed at Knotgrass Road, Touchet River, 1988. Manual Flows were also measured at the same location.

\begin{tabular}{|c|c|c|c|c|c|c|c|c|}
\hline Date & $\begin{array}{r}\text { Min } \\
\text { Time }\end{array}$ & $\begin{array}{r}\text { Min } \\
\text { Temp (F) } \\
\end{array}$ & $\begin{array}{r}\text { Max } \\
\text { Time }\end{array}$ & $\begin{array}{r}\text { Max } \\
\text { Temp (F) } \\
\end{array}$ & $\begin{array}{r}\text { Daily } \\
\text { Mean (F) } \\
\end{array}$ & $\begin{array}{l}\text { Daily } \\
\text { Mode }\end{array}$ & $\begin{array}{r}\text { Flows } \\
\text { (cfs) }\end{array}$ & Notes \\
\hline $07 / 25 / 98$ & $07: 26$ & 67.9 & $17: 41$ & 84.7 & 76.2 & 84.0 & & \\
\hline $07 / 26 / 98$ & $07: 11$ & 69.4 & $17: 26$ & 86.4 & 77.6 & 86.0 & & \\
\hline $07 / 27 / 98$ & $07: 11$ & 69.4 & $17: 11$ & 86.0 & 77.5 & 70.0 & & \\
\hline $07 / 28 / 98$ & $07: 26$ & 70.6 & $17: 26$ & 86.0 & 78.0 & 71.0 & & \\
\hline $07 / 29 / 98$ & $07: 26$ & 69.7 & $17: 11$ & 82.1 & 75.7 & 76.0 & & \\
\hline 07/30/98 & $07: 11$ & 71.2 & $15: 56$ & 83.7 & 76.0 & 75.0 & & \\
\hline $07 / 31 / 98$ & $12: 56$ & 72.4 & $01: 11$ & 74.8 & 73.4 & 73.0 & & \\
\hline 08/01/98 & $10: 26$ & 69.1 & $21: 11$ & 74.2 & 71.7 & 74.0 & & \\
\hline 08/02/98 & 09:56 & 70.0 & $21: 26$ & 77.3 & 73.4 & 77.0 & & \\
\hline 08/03/98 & $07: 56$ & 68.8 & $17: 30$ & 86.1 & 77.0 & 85.0 & 46.7 & \\
\hline 08/04/98 & $07: 30$ & 68.8 & $17: 00$ & 87.1 & 77.7 & 69.0 & & \\
\hline $08 / 05 / 98$ & $07: 30$ & 71.2 & $16: 30$ & 81.8 & 76.3 & 72.0 & & \\
\hline 08/06/98 & 07:00 & 66.2 & $17: 00$ & 80.2 & 72.8 & 67.0 & & \\
\hline 08/07/98 & 07:30 & 64.2 & $17: 00$ & 77.1 & 70.5 & 77.0 & & \\
\hline 08/08/98 & 08:00 & 62.2 & $17: 30$ & 79.9 & 70.6 & 62.0 & & \\
\hline 08/09/98 & $07: 30$ & 63.9 & $17: 30$ & 80.5 & 72.3 & 64.0 & & \\
\hline 08/10/98 & 08:00 & 66.5 & $17: 00$ & 80.5 & 73.3 & 67.0 & & \\
\hline $08 / 11 / 98$ & 07:00 & 66.2 & $17: 00$ & 81.5 & 73.4 & 81.0 & & \\
\hline $08 / 12 / 98$ & $07: 30$ & 65.9 & $17: 30$ & 82.5 & 74.1 & 67.0 & & \\
\hline 08/13/98 & $07: 30$ & 67.1 & $17: 00$ & 83.8 & 75.3 & 83.0 & & \\
\hline $08 / 14 / 98$ & 08:00 & 67.4 & $16: 30$ & 82.1 & 74.6 & 81.0 & & \\
\hline $08 / 15 / 98$ & $07: 30$ & 66.8 & $16: 00$ & 78.3 & 71.9 & 67.0 & & \\
\hline $08 / 16 / 98$ & $07: 30$ & 60.2 & $17: 00$ & 72.7 & 66.4 & 60.0 & & \\
\hline 08/17/98 & $07: 30$ & 60.2 & $16: 30$ & 73.3 & 66.4 & 73.0 & & \\
\hline 08/18/98 & 08:00 & 59.3 & $17: 30$ & 73.0 & 65.9 & 60.0 & & \\
\hline 08/19/98 & $07: 30$ & 59.0 & $17: 28$ & 75.5 & 67.0 & 75.0 & 41.3 & \\
\hline $08 / 20 / 98$ & $07: 58$ & 62.2 & $14: 58$ & 74.3 & 68.3 & 74.0 & & \\
\hline $08 / 21 / 98$ & $07: 28$ & 64.2 & $16: 28$ & 77.4 & 70.4 & 77.0 & & \\
\hline $08 / 22 / 98$ & $07: 28$ & 63.9 & $16: 28$ & 76.7 & 70.1 & 64.0 & & \\
\hline $08 / 23 / 98$ & 09:28 & 63.6 & $15: 58$ & 71.5 & 67.3 & 64.0 & & \\
\hline $08 / 24 / 98$ & $07: 28$ & 60.2 & $17: 28$ & 74.6 & 67.1 & 61.0 & & \\
\hline $08 / 25 / 98$ & $06: 58$ & 60.8 & $16: 58$ & 74.9 & 67.7 & 61.0 & & \\
\hline $08 / 26 / 98$ & $06: 58$ & 62.2 & $16: 28$ & 73.9 & 67.8 & 62.0 & & \\
\hline $08 / 27 / 98$ & $07: 58$ & 59.9 & $17: 58$ & 74.6 & 67.2 & 60.0 & & \\
\hline $08 / 28 / 98$ & $07: 28$ & 61.0 & $16: 58$ & 77.1 & 69.1 & 61.0 & & \\
\hline 08/29/98 & $07: 28$ & 64.2 & $15: 58$ & 76.4 & 70.1 & 76.0 & & \\
\hline 08/30/98 & $07: 28$ & 61.6 & $16: 58$ & 76.7 & 69.1 & 62.0 & & \\
\hline $08 / 31 / 98$ & $07: 28$ & 62.7 & $17: 28$ & 77.4 & 70.2 & 77.0 & & \\
\hline 09/01/98 & $08: 28$ & 63.9 & $16: 58$ & 77.4 & 70.7 & 77.0 & & \\
\hline
\end{tabular}


Summary of Daily Temperature Values for the Continuous Instream Monitor Placed at Knotgrass Road, Touchet River, 1988. Manual Flows were also measured at the same location.

\begin{tabular}{|c|c|c|c|c|c|c|c|c|}
\hline Date & $\begin{array}{c}\text { Min } \\
\text { Time }\end{array}$ & $\begin{array}{r}\text { Min } \\
\text { Temp (F) } \\
\end{array}$ & $\begin{array}{r}\text { Max } \\
\text { Time } \\
\end{array}$ & $\begin{array}{r}\text { Max } \\
\text { Temp (F) } \\
\end{array}$ & $\begin{array}{r}\text { Daily } \\
\text { Mean (F) } \\
\end{array}$ & $\begin{array}{l}\text { Daily } \\
\text { Mode }\end{array}$ & $\begin{array}{r}\text { Flows } \\
\text { (cfs) }\end{array}$ & Notes \\
\hline $09 / 02 / 98$ & $06: 58$ & 64.5 & $16: 58$ & 77.4 & 70.6 & 67.0 & & \\
\hline 09/03/98 & $07: 58$ & 62.7 & $17: 28$ & 78.0 & 70.6 & 63.0 & & \\
\hline 09/04/98 & $07: 28$ & 65.3 & $16: 58$ & 78.0 & 71.5 & 67.0 & & \\
\hline $09 / 05 / 98$ & $07: 58$ & 63.9 & $16: 28$ & 75.5 & 70.1 & 75.0 & & \\
\hline 09/06/98 & $07: 58$ & 61.6 & $16: 58$ & 75.2 & 68.7 & 75.0 & & \\
\hline 09/07/98 & $07: 28$ & 63.3 & $17: 28$ & 69.7 & 67.2 & 69.0 & & \\
\hline 09/08/98 & $06: 58$ & 63.6 & $15: 28$ & 73.9 & 68.3 & 64.0 & & \\
\hline 09/09/98 & $10: 58$ & 62.2 & $00: 28$ & 67.1 & 63.7 & 63.0 & & \\
\hline 09/10/98 & $07: 58$ & 59.9 & $16: 58$ & 68.0 & 63.3 & 60.0 & & \\
\hline 09/11/98 & $07: 58$ & 57.6 & $17: 28$ & 70.0 & 63.9 & 58.0 & & \\
\hline 09/12/98 & $07: 58$ & 57.9 & $17: 28$ & 70.9 & 64.5 & 58.0 & & \\
\hline 09/13/98 & $07: 58$ & 59.6 & $16: 58$ & 71.2 & 65.4 & 60.0 & & \\
\hline 09/14/98 & $07: 58$ & 59.3 & $16: 58$ & 72.4 & 65.9 & 72.0 & & \\
\hline 09/15/98 & $07: 28$ & 60.8 & $16: 58$ & 72.7 & 67.0 & 72.0 & & \\
\hline $09 / 16 / 98$ & $08: 28$ & 65.1 & $15: 28$ & 74.3 & 69.2 & 66.0 & & \\
\hline 09/17/98 & $07: 58$ & 62.7 & $16: 28$ & 70.9 & 66.4 & 64.0 & & \\
\hline 09/18/98 & $07: 58$ & 59.0 & $16: 30$ & 64.5 & 61.8 & 64.0 & 38.0 & \\
\hline 09/19/98 & $07: 30$ & 57.4 & $14: 00$ & 64.2 & 60.7 & 64.0 & & \\
\hline 09/20/98 & $06: 30$ & 58.2 & $17: 00$ & 63.9 & 60.6 & 58.0 & & \\
\hline $09 / 21 / 98$ & 08:00 & 55.1 & $17: 00$ & 65.1 & 60.1 & 65.0 & & \\
\hline $09 / 22 / 98$ & $07: 30$ & 55.4 & $17: 30$ & 65.6 & 60.6 & 64.0 & & \\
\hline 09/23/98 & 08:00 & 57.4 & $16: 30$ & 66.8 & 62.0 & 58.0 & & \\
\hline $09 / 24 / 98$ & $07: 30$ & 56.8 & $16: 00$ & 63.9 & 60.4 & 57.0 & & \\
\hline $09 / 25 / 98$ & 08:00 & 57.9 & $14: 00$ & 61.3 & 59.4 & 58.0 & & \\
\hline $09 / 26 / 98$ & 07:00 & 56.5 & $15: 30$ & 62.5 & 59.1 & 58.0 & & \\
\hline $09 / 27 / 98$ & $07: 30$ & 54.0 & $17: 00$ & 63.6 & 59.0 & 55.0 & & \\
\hline $09 / 28 / 98$ & 09:00 & 54.9 & $17: 00$ & 64.2 & 59.5 & 64.0 & & \\
\hline 09/29/98 & 08:00 & 54.9 & $16: 30$ & 64.5 & 59.8 & 64.0 & & \\
\hline 09/30/98 & 07:30 & 55.4 & $17: 00$ & 64.2 & 59.9 & 64.0 & & \\
\hline $10 / 01 / 98$ & 07:00 & 55.4 & $15: 30$ & 63.0 & 59.2 & 58.0 & & \\
\hline $10 / 02 / 98$ & 08:30 & 54.6 & 00:00 & 58.8 & 56.8 & 58.0 & & \\
\hline $10 / 03 / 98$ & 08:00 & 51.3 & $15: 00$ & 56.8 & 54.1 & 52.0 & & \\
\hline $10 / 04 / 98$ & 07:00 & 51.5 & $17: 00$ & 58.2 & 54.4 & 52.0 & & \\
\hline $10 / 05 / 98$ & 08:00 & 49.0 & $16: 30$ & 57.1 & 53.2 & 57.0 & & \\
\hline $10 / 06 / 98$ & 08:00 & 49.9 & $18: 30$ & 58.5 & 54.4 & 58.0 & & \\
\hline $10 / 07 / 98$ & $07: 30$ & 52.4 & $16: 00$ & 59.9 & 56.0 & 53.0 & & \\
\hline $10 / 08 / 98$ & $07: 30$ & 53.2 & $14: 30$ & 57.4 & 55.0 & 55.0 & & \\
\hline $10 / 09 / 98$ & 08:30 & 51.0 & $16: 00$ & 56.8 & 53.8 & 52.0 & & \\
\hline $10 / 10 / 98$ & 08:00 & 51.0 & $15: 30$ & 56.0 & 53.3 & 52.0 & & \\
\hline
\end{tabular}


Summary of Daily Temperature Values for the Continuous Instream Monitor Placed at Knotgrass Road, Touchet River, 1988. Manual Flows were also measured at the same location.

\begin{tabular}{|c|c|c|c|c|c|c|c|c|}
\hline Date & $\begin{array}{r}\text { Min } \\
\text { Time }\end{array}$ & $\begin{array}{r}\text { Min } \\
\text { Temp (F) } \\
\end{array}$ & $\begin{array}{r}\text { Max } \\
\text { Time } \\
\end{array}$ & $\begin{array}{r}\text { Max } \\
\text { Temp (F) } \\
\end{array}$ & $\begin{array}{r}\text { Daily } \\
\text { Mean (F) } \\
\end{array}$ & $\begin{array}{l}\text { Daily } \\
\text { Mode }\end{array}$ & $\begin{array}{r}\text { Flows } \\
\text { (cfs) }\end{array}$ & Notes \\
\hline $10 / 11 / 98$ & $07: 30$ & 47.1 & $16: 30$ & 54.0 & 50.8 & 54.0 & & \\
\hline $10 / 12 / 98$ & 08:30 & 49.0 & $16: 00$ & 54.9 & 52.0 & 50.0 & & \\
\hline $10 / 13 / 98$ & 07:00 & 51.5 & $17: 00$ & 57.4 & 54.2 & 52.0 & & \\
\hline $10 / 14 / 98$ & $23: 30$ & 50.4 & $13: 00$ & 54.9 & 52.6 & 51.0 & & \\
\hline $10 / 15 / 98$ & 09:00 & 47.9 & $15: 00$ & 52.6 & 49.9 & 48.0 & & \\
\hline $10 / 16 / 98$ & 08:00 & 45.7 & $17: 00$ & 51.3 & 48.6 & 51.0 & & \\
\hline $10 / 17 / 98$ & 08:00 & 44.9 & $21: 30$ & 51.0 & 48.2 & 51.0 & & \\
\hline $10 / 18 / 98$ & 08:00 & 48.2 & $16: 00$ & 52.4 & 50.4 & 52.0 & & \\
\hline $10 / 19 / 98$ & $07: 30$ & 44.6 & 18:00 & 50.1 & 47.6 & 50.0 & & \\
\hline $10 / 20 / 98$ & 08:00 & 43.8 & 18:00 & 49.6 & 46.8 & 49.0 & & \\
\hline $10 / 21 / 98$ & 08:00 & 43.5 & $18: 00$ & 49.9 & 46.9 & 50.0 & & \\
\hline $10 / 22 / 98$ & 08:30 & 44.0 & $17: 30$ & 50.1 & 47.3 & 50.0 & & \\
\hline $10 / 23 / 98$ & 08:00 & 45.4 & $17: 00$ & 51.3 & 48.6 & 51.0 & & \\
\hline $10 / 24 / 98$ & 08:00 & 46.0 & $16: 00$ & 51.0 & 48.8 & 50.0 & & \\
\hline $10 / 25 / 98$ & 07:30 & 48.2 & $14: 30$ & 53.5 & 50.6 & 49.0 & & \\
\hline $10 / 26 / 98$ & 08:00 & 46.5 & 18:00 & 51.8 & 49.6 & 52.0 & & \\
\hline $10 / 27 / 98$ & 08:30 & 46.3 & 19:00 & 51.0 & 49.1 & 51.0 & & \\
\hline $10 / 28 / 98$ & 08:30 & 47.4 & $15: 43$ & 50.4 & 49.3 & 50.0 & 59.8 & \\
\hline $10 / 29 / 98$ & 08:13 & 44.3 & $14: 13$ & 47.9 & 46.4 & 45.0 & & \\
\hline $10 / 30 / 98$ & 07:43 & 41.2 & $16: 43$ & 46.0 & 44.0 & 45.0 & & \\
\hline $10 / 31 / 98$ & $08: 13$ & 42.4 & $17: 43$ & 47.1 & 45.2 & 47.0 & & \\
\hline $11 / 01 / 98$ & $23: 43$ & 45.1 & $15: 43$ & 47.4 & 46.5 & 47.0 & & \\
\hline $11 / 02 / 98$ & $06: 43$ & 44.6 & $15: 43$ & 48.5 & 46.0 & 45.0 & & \\
\hline $11 / 03 / 98$ & 08:43 & 41.5 & $19: 13$ & 46.0 & 44.3 & 46.0 & & \\
\hline $11 / 04 / 98$ & $07: 43$ & 45.4 & $15: 43$ & 48.5 & 46.7 & 48.0 & & \\
\hline $11 / 05 / 98$ & $02: 43$ & 46.5 & $11: 43$ & 47.1 & 46.8 & 47.0 & 66.1 & $\begin{array}{l}\text { monitor removed } \\
11: 43 \mathrm{hrs} \text {. }\end{array}$ \\
\hline
\end{tabular}




\section{Summary of Daily Temperature Values for the Continuous Instream Monitor Placed at Lamar Rd., Touchet River, 1998}

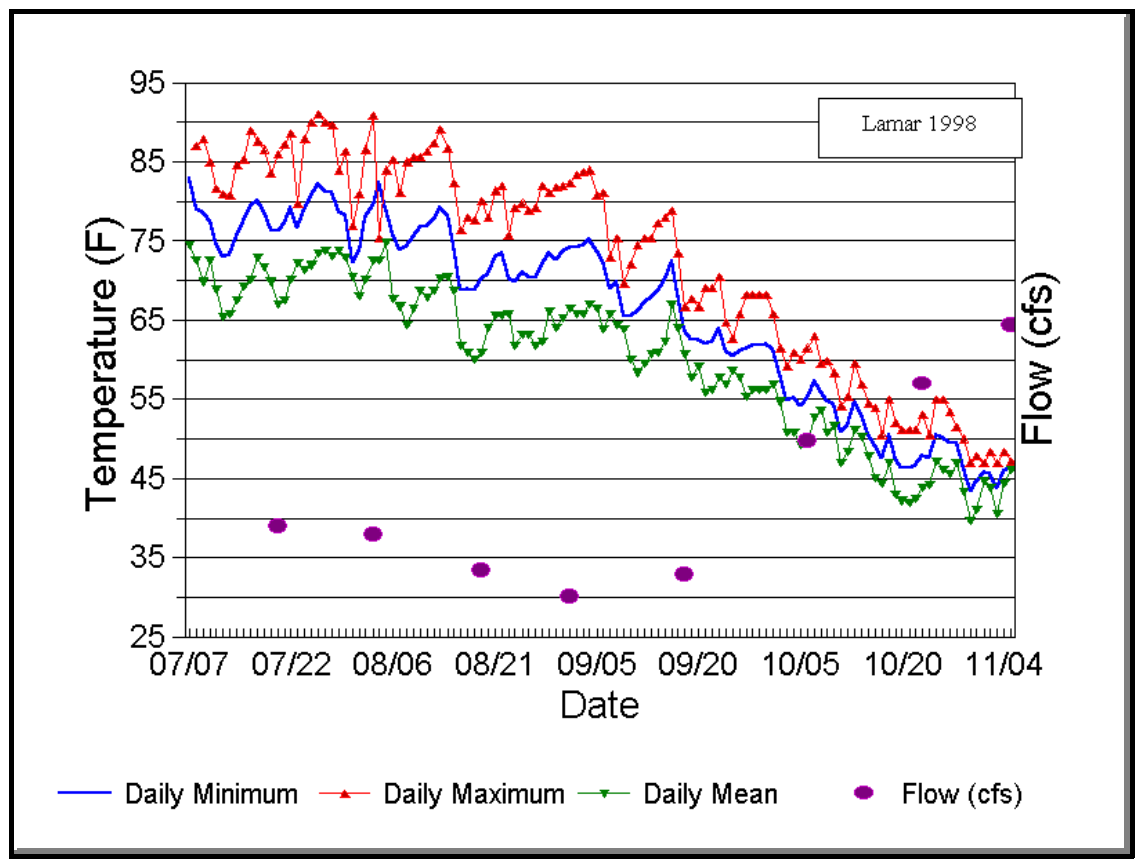

Summary of Daily Temperature Values for the Continuous Instream Monitor Placed at Lamar Rd., Touchet River, 1998. Manual flows also measured at the same location.

\begin{tabular}{|c|c|c|c|c|c|c|c|c|}
\hline Date & $\begin{array}{r}\text { Min } \\
\text { Time }\end{array}$ & $\begin{array}{r}\text { Min } \\
\text { Temp (F) } \\
\end{array}$ & $\begin{array}{r}\text { Max } \\
\text { Time } \\
\end{array}$ & $\begin{array}{r}\text { Max } \\
\text { Temp (F) } \\
\end{array}$ & $\begin{array}{r}\text { Daily } \\
\text { Mean (F) } \\
\end{array}$ & $\begin{array}{l}\text { Daily } \\
\text { Mode } \\
\end{array}$ & $\begin{array}{r}\text { Flows } \\
\text { (cfs) }\end{array}$ & Notes \\
\hline $07 / 07 / 98$ & $10: 30$ & 74.4 & $17: 00$ & $10: 30$ & 82.9 & 87.0 & & monitor installed \\
\hline 07/08/98 & $07: 15$ & 72.6 & $17: 00$ & 86.9 & 79.1 & 73.0 & & 10:15 hrs. \\
\hline 07/09/98 & 07:00 & 69.9 & $17: 15$ & 88.0 & 78.6 & 70.0 & & \\
\hline 07/10/98 & $07: 15$ & 72.6 & $16: 30$ & 84.9 & 77.6 & 73.0 & & \\
\hline $07 / 11 / 98$ & $07: 30$ & 69.0 & $17: 00$ & 81.6 & 74.7 & 73.0 & & \\
\hline $07 / 12 / 98$ & 07:00 & 65.5 & $16: 30$ & 81.0 & 72.9 & 66.0 & & \\
\hline 07/13/98 & $07: 15$ & 65.8 & $17: 00$ & 80.7 & 73.4 & 66.0 & & \\
\hline $07 / 14 / 98$ & $07: 30$ & 67.5 & $17: 00$ & 84.6 & 75.7 & 68.0 & & \\
\hline $07 / 15 / 98$ & 07:00 & 69.3 & $15: 30$ & 85.3 & 77.5 & 85.0 & & \\
\hline $07 / 16 / 98$ & 07:00 & 70.2 & $17: 15$ & 89.0 & 79.5 & 89.0 & & \\
\hline 07/17/98 & 07:00 & 72.9 & $17: 00$ & 87.6 & 80.1 & 73.0 & & \\
\hline $07 / 18 / 98$ & 07:00 & 71.7 & $17: 15$ & 86.6 & 78.7 & 72.0 & & \\
\hline 07/19/98 & $07: 30$ & 69.9 & $17: 15$ & 83.6 & 76.4 & 70.0 & & \\
\hline 07/20/98 & 07:00 & 67.0 & $17: 26$ & 85.9 & 76.3 & 67.0 & 39.1 & \\
\hline $07 / 21 / 98$ & 07:11 & 67.5 & $17: 41$ & 87.3 & 77.3 & 68.0 & & \\
\hline $07 / 22 / 98$ & $06: 41$ & 70.2 & $17: 11$ & 88.7 & 79.2 & 88.0 & & \\
\hline
\end{tabular}


Summary of Daily Temperature Values for the Continuous Instream Monitor Placed at Lamar Rd., Touchet River, 1998. Manual flows also measured at the same location.

\begin{tabular}{|c|c|c|c|c|c|c|c|c|}
\hline Date & $\begin{array}{c}\text { Min } \\
\text { Time }\end{array}$ & $\begin{array}{r}\text { Min } \\
\text { Temp (F) }\end{array}$ & $\begin{array}{r}\text { Max } \\
\text { Time }\end{array}$ & $\begin{array}{r}\text { Max } \\
\text { Temp (F) }\end{array}$ & $\begin{array}{r}\text { Daily } \\
\text { Mean (F) }\end{array}$ & $\begin{array}{l}\text { Daily } \\
\text { Mode }\end{array}$ & $\begin{array}{r}\text { Flows } \\
\text { (cfs) }\end{array}$ & Notes \\
\hline $07 / 23 / 98$ & $06: 56$ & 72.3 & $17: 56$ & 79.7 & 76.7 & 78.0 & & \\
\hline $07 / 24 / 98$ & $06: 56$ & 71.4 & $17: 41$ & 88.0 & 79.1 & 72.0 & & \\
\hline $07 / 25 / 98$ & $06: 56$ & 72.0 & $17: 41$ & 90.1 & 80.9 & 73.0 & & \\
\hline $07 / 26 / 98$ & $06: 56$ & 73.5 & $16: 26$ & 91.1 & 82.2 & 74.0 & & \\
\hline $07 / 27 / 98$ & $07: 11$ & 73.8 & $16: 41$ & 90.1 & 81.3 & 74.0 & & \\
\hline $07 / 28 / 98$ & $07: 26$ & 73.2 & $17: 41$ & 89.7 & 81.2 & 78.0 & & \\
\hline $07 / 29 / 98$ & $07: 41$ & 73.8 & 18:41 & 83.9 & 78.8 & 79.0 & & \\
\hline $07 / 30 / 98$ & $07: 56$ & 72.9 & $16: 26$ & 86.3 & 78.3 & 73.0 & & \\
\hline $07 / 31 / 98$ & $10: 26$ & 70.5 & $00: 26$ & 76.9 & 72.3 & 72.0 & & \\
\hline $08 / 01 / 98$ & 09:41 & 68.1 & $18: 41$ & 81.0 & 73.8 & 68.0 & & \\
\hline $08 / 02 / 98$ & $07: 56$ & 70.2 & $17: 56$ & 86.6 & 78.1 & 86.0 & & \\
\hline $08 / 03 / 98$ & 08:11 & 72.6 & $17: 30$ & 90.8 & 79.6 & 73.0 & 38.0 & \\
\hline $08 / 04 / 98$ & 07:00 & 72.7 & $23: 30$ & 75.4 & 82.4 & 73.0 & & \\
\hline $08 / 05 / 98$ & 07:30 & 74.8 & $15: 30$ & 84.0 & 79.1 & 75.0 & & \\
\hline $08 / 06 / 98$ & 07:00 & 67.6 & $17: 00$ & 85.3 & 75.9 & 68.0 & & \\
\hline 08/07/98 & 08:00 & 66.8 & $16: 00$ & 81.1 & 73.8 & 67.0 & & \\
\hline 08/08/98 & 07:30 & 64.4 & $17: 00$ & 85.0 & 74.3 & 65.0 & & \\
\hline 08/09/98 & 07:30 & 66.5 & $17: 00$ & 85.7 & 75.6 & 67.0 & & \\
\hline $08 / 10 / 98$ & $07: 30$ & 68.8 & $17: 30$ & 85.7 & 76.8 & 69.0 & & \\
\hline $08 / 11 / 98$ & 07:00 & 67.9 & $16: 30$ & 86.3 & 77.0 & 86.0 & & \\
\hline $08 / 12 / 98$ & $07: 30$ & 68.8 & $17: 00$ & 87.4 & 77.8 & 69.0 & & \\
\hline $08 / 13 / 98$ & $07: 30$ & 70.3 & $17: 00$ & 89.1 & 79.3 & 71.0 & & \\
\hline $08 / 14 / 98$ & 07:30 & 70.6 & $17: 00$ & 86.7 & 78.3 & 71.0 & & \\
\hline $08 / 15 / 98$ & $23: 30$ & 68.8 & $16: 30$ & 82.4 & 74.6 & 70.0 & & \\
\hline $08 / 16 / 98$ & 07:30 & 61.8 & $17: 00$ & 76.4 & 68.7 & 62.0 & & \\
\hline $08 / 17 / 98$ & 08:00 & 61.0 & $16: 30$ & 77.9 & 69.1 & 61.0 & & \\
\hline $08 / 18 / 98$ & 07:30 & 60.1 & $17: 30$ & 77.6 & 68.8 & 61.0 & & \\
\hline $08 / 19 / 98$ & 07:30 & 61.0 & $17: 26$ & 80.1 & 70.2 & 62.0 & 33.5 & \\
\hline 08/20/98 & $07: 26$ & 64.1 & $15: 26$ & 77.9 & 70.8 & 71.0 & & \\
\hline $08 / 21 / 98$ & $06: 56$ & 65.6 & $15: 56$ & 81.4 & 73.0 & 66.0 & & \\
\hline $08 / 22 / 98$ & $06: 56$ & 65.6 & $17: 26$ & 82.0 & 73.5 & 66.0 & & \\
\hline $08 / 23 / 98$ & $08: 26$ & 65.9 & $15: 26$ & 75.7 & 70.3 & 66.0 & & \\
\hline $08 / 24 / 98$ & $06: 56$ & 61.8 & $16: 56$ & 79.2 & 70.0 & 62.0 & & \\
\hline $08 / 25 / 98$ & $07: 56$ & 63.3 & $16: 26$ & 79.8 & 71.2 & 64.0 & & \\
\hline $08 / 26 / 98$ & $07: 56$ & 63.3 & $16: 56$ & 78.8 & 70.6 & 64.0 & & \\
\hline $08 / 27 / 98$ & $07: 26$ & 61.8 & $16: 56$ & 79.2 & 70.3 & 79.0 & & \\
\hline $08 / 28 / 98$ & $07: 56$ & 62.4 & $16: 56$ & 82.0 & 72.1 & 63.0 & & \\
\hline $08 / 29 / 98$ & $07: 26$ & 66.2 & $16: 26$ & 81.1 & 73.5 & 72.0 & & \\
\hline $08 / 30 / 98$ & $06: 56$ & 64.1 & $16: 56$ & 81.7 & 72.7 & 64.0 & & \\
\hline
\end{tabular}


Summary of Daily Temperature Values for the Continuous Instream Monitor Placed at Lamar Rd., Touchet River, 1998. Manual flows also measured at the same location.

\begin{tabular}{|c|c|c|c|c|c|c|c|c|}
\hline Date & $\begin{array}{r}\text { Min } \\
\text { Time }\end{array}$ & $\begin{array}{r}\text { Min } \\
\text { Temp (F) }\end{array}$ & $\begin{array}{r}\text { Max } \\
\text { Time }\end{array}$ & $\begin{array}{r}\text { Max } \\
\text { Temp (F) }\end{array}$ & $\begin{array}{r}\text { Daily } \\
\text { Mean (F) }\end{array}$ & $\begin{array}{l}\text { Daily } \\
\text { Mode }\end{array}$ & $\begin{array}{r}\text { Flows } \\
\text { (cfs) }\end{array}$ & Notes \\
\hline $08 / 31 / 98$ & $07: 56$ & 65.3 & $17: 26$ & 82.0 & 73.7 & 66.0 & & \\
\hline $09 / 01 / 98$ & 07:56 & 66.5 & $17: 26$ & 82.4 & 74.2 & 82.0 & 30.1 & \\
\hline $09 / 02 / 98$ & $06: 56$ & 65.9 & $17: 26$ & 83.4 & 74.3 & 66.0 & & \\
\hline $09 / 03 / 98$ & $07: 56$ & 65.9 & $16: 56$ & 83.7 & 74.5 & 66.0 & & \\
\hline 09/04/98 & $07: 26$ & 67.1 & $17: 26$ & 84.0 & 75.3 & 84.0 & & \\
\hline $09 / 05 / 98$ & 07:56 & 66.5 & $16: 56$ & 80.8 & 73.8 & 67.0 & & \\
\hline $09 / 06 / 98$ & $07: 56$ & 63.8 & $16: 56$ & 81.1 & 72.4 & 64.0 & & \\
\hline $09 / 07 / 98$ & $07: 56$ & 65.9 & $00: 26$ & 73.0 & 69.1 & 70.0 & & \\
\hline 09/08/98 & $06: 56$ & 64.4 & $15: 26$ & 75.4 & 69.9 & 71.0 & & \\
\hline 09/09/98 & $10: 56$ & 63.8 & $00: 26$ & 69.7 & 65.7 & 64.0 & & \\
\hline 09/10/98 & $07: 56$ & 60.1 & $16: 56$ & 72.1 & 65.5 & 61.0 & & \\
\hline $09 / 11 / 98$ & $07: 26$ & 58.4 & $16: 56$ & 74.5 & 66.3 & 74.0 & & \\
\hline $09 / 12 / 98$ & 07:56 & 59.6 & $16: 26$ & 75.4 & 67.3 & 60.0 & & \\
\hline $09 / 13 / 98$ & $07: 26$ & 60.7 & $17: 26$ & 75.4 & 68.0 & 75.0 & & \\
\hline $09 / 14 / 98$ & $07: 26$ & 61.0 & $17: 26$ & 77.3 & 68.9 & 77.0 & & \\
\hline $09 / 15 / 98$ & 07:56 & 62.4 & $16: 56$ & 77.9 & 70.2 & 63.0 & & \\
\hline $09 / 16 / 98$ & $07: 56$ & 67.1 & $17: 26$ & 78.8 & 72.5 & 71.0 & & \\
\hline 09/17/98 & $07: 56$ & 64.1 & $16: 56$ & 73.6 & 68.5 & 66.0 & & \\
\hline $09 / 18 / 98$ & $06: 56$ & 60.7 & $16: 00$ & 66.8 & 63.7 & 66.0 & 32.9 & \\
\hline $09 / 19 / 98$ & 07:00 & 57.9 & $16: 30$ & 67.6 & 62.5 & 58.0 & & \\
\hline 09/20/98 & $08: 30$ & 59.3 & $17: 00$ & 66.8 & 62.5 & 60.0 & & \\
\hline $09 / 21 / 98$ & $07: 30$ & 55.9 & $16: 30$ & 69.1 & 62.1 & 56.0 & & \\
\hline $09 / 22 / 98$ & $07: 30$ & 56.2 & $17: 00$ & 69.1 & 62.4 & 56.0 & & \\
\hline $09 / 23 / 98$ & 08:00 & 57.9 & $17: 00$ & 70.6 & 63.9 & 58.0 & & \\
\hline $09 / 24 / 98$ & $07: 30$ & 57.0 & $15: 30$ & 64.7 & 61.1 & 62.0 & & \\
\hline $09 / 25 / 98$ & $08: 30$ & 58.7 & $14: 30$ & 62.7 & 60.6 & 60.0 & & \\
\hline $09 / 26 / 98$ & 08:00 & 57.9 & $17: 30$ & 65.9 & 61.1 & 58.0 & & \\
\hline $09 / 27 / 98$ & 08:00 & 55.3 & $17: 00$ & 68.2 & 61.4 & 68.0 & & \\
\hline $09 / 28 / 98$ & 08:00 & 56.2 & $16: 30$ & 68.2 & 61.8 & 68.0 & & \\
\hline $09 / 29 / 98$ & 07:00 & 56.2 & $16: 00$ & 68.2 & 61.9 & 58.0 & & \\
\hline $09 / 30 / 98$ & $08: 30$ & 56.2 & $16: 30$ & 68.2 & 62.0 & 68.0 & & \\
\hline $10 / 01 / 98$ & $07: 30$ & 57.0 & $15: 30$ & 65.9 & 61.4 & 58.0 & & \\
\hline $10 / 02 / 98$ & 09:00 & 54.8 & $15: 30$ & 61.5 & 58.2 & 56.0 & & \\
\hline $10 / 03 / 98$ & $08: 30$ & 50.9 & $15: 00$ & 59.3 & 54.9 & 51.0 & & \\
\hline $10 / 04 / 98$ & $08: 30$ & 50.9 & $15: 30$ & 61.0 & 55.2 & 51.0 & & \\
\hline $10 / 05 / 98$ & 08:00 & 49.2 & $16: 00$ & 60.1 & 54.3 & 50.0 & & \\
\hline $10 / 06 / 98$ & $07: 30$ & 49.8 & $17: 00$ & 61.5 & 55.3 & 50.0 & 49.8 & \\
\hline $10 / 07 / 98$ & 08:00 & 52.8 & $16: 00$ & 63.0 & 57.4 & 53.0 & & \\
\hline $10 / 08 / 98$ & 07:00 & 53.7 & $16: 30$ & 59.6 & 56.0 & 54.0 & & \\
\hline
\end{tabular}


Summary of Daily Temperature Values for the Continuous Instream Monitor Placed at Lamar Rd., Touchet River, 1998. Manual flows also measured at the same location.

\begin{tabular}{|c|c|c|c|c|c|c|c|c|}
\hline Date & $\begin{array}{r}\text { Min } \\
\text { Time }\end{array}$ & $\begin{array}{r}\text { Min } \\
\text { Temp (F) } \\
\end{array}$ & $\begin{array}{r}\text { Max } \\
\text { Time } \\
\end{array}$ & $\begin{array}{r}\text { Max } \\
\text { Temp (F) } \\
\end{array}$ & $\begin{array}{r}\text { Daily } \\
\text { Mean (F) }\end{array}$ & $\begin{array}{l}\text { Daily } \\
\text { Mode }\end{array}$ & $\begin{array}{r}\text { Flows } \\
\text { (cfs) }\end{array}$ & Notes \\
\hline $10 / 09 / 98$ & $08: 00$ & 50.9 & $16: 00$ & 59.8 & 54.9 & 51.0 & & \\
\hline $10 / 10 / 98$ & 08:30 & 51.7 & $16: 00$ & 58.4 & 54.4 & 53.0 & & \\
\hline $10 / 11 / 98$ & 08:00 & 47.0 & $16: 30$ & 54.2 & 50.8 & 54.0 & & \\
\hline $10 / 12 / 98$ & 08:30 & 48.4 & $17: 30$ & 55.3 & 51.8 & 55.0 & & \\
\hline $10 / 13 / 98$ & 08:00 & 51.2 & $16: 00$ & 59.6 & 54.7 & 52.0 & & \\
\hline $10 / 14 / 98$ & 08:30 & 50.3 & 15:00 & 57.0 & 53.2 & 51.0 & & \\
\hline $10 / 15 / 98$ & 08:30 & 47.8 & $16: 30$ & 54.5 & 50.6 & 49.0 & & \\
\hline $10 / 16 / 98$ & 08:00 & 45.0 & $16: 00$ & 54.0 & 49.2 & 48.0 & & \\
\hline $10 / 17 / 98$ & 08:30 & 44.5 & $22: 30$ & 50.6 & 47.6 & 50.0 & & \\
\hline $10 / 18 / 98$ & 09:00 & 47.0 & $16: 00$ & 55.1 & 50.6 & 49.0 & & \\
\hline $10 / 19 / 98$ & 09:00 & 43.1 & $16: 00$ & 52.0 & 47.4 & 48.0 & & \\
\hline $10 / 20 / 98$ & 08:00 & 42.2 & $16: 30$ & 51.2 & 46.4 & 46.0 & & \\
\hline $10 / 21 / 98$ & 08:30 & 42.0 & $16: 30$ & 51.2 & 46.3 & 44.0 & & \\
\hline $10 / 22 / 98$ & 09:00 & 42.5 & $17: 00$ & 51.2 & 46.7 & 43.0 & & \\
\hline $10 / 23 / 98$ & 08:30 & 43.9 & $16: 16$ & 53.1 & 48.0 & 44.0 & 57.0 & \\
\hline $10 / 24 / 98$ & 08:46 & 44.2 & $16: 16$ & 50.6 & 47.6 & 49.0 & & \\
\hline $10 / 25 / 98$ & $07: 16$ & 47.3 & $15: 16$ & 55.1 & 50.5 & 48.0 & & \\
\hline $10 / 26 / 98$ & $08: 16$ & 46.1 & $16: 16$ & 55.1 & 50.1 & 47.0 & & \\
\hline $10 / 27 / 98$ & 08:46 & 45.6 & $15: 46$ & 53.4 & 49.5 & 46.0 & & \\
\hline $10 / 28 / 98$ & 09:46 & 47.0 & $15: 46$ & 51.4 & 49.4 & 51.0 & & \\
\hline $10 / 29 / 98$ & $08: 16$ & 43.4 & $15: 46$ & 50.0 & 46.4 & 44.0 & & \\
\hline $10 / 30 / 98$ & 09:16 & 39.7 & $15: 46$ & 47.0 & 43.4 & 44.0 & & \\
\hline $10 / 31 / 98$ & $07: 46$ & 41.1 & $15: 46$ & 47.8 & 44.7 & 46.0 & & \\
\hline $11 / 01 / 98$ & $22: 46$ & 44.8 & $16: 46$ & 47.0 & 45.9 & 46.0 & & \\
\hline $11 / 02 / 98$ & $08: 16$ & 43.9 & $15: 46$ & 48.4 & 45.7 & 44.0 & & \\
\hline $11 / 03 / 98$ & 09:46 & 40.5 & $16: 16$ & 47.0 & 43.8 & 41.0 & & \\
\hline $11 / 04 / 98$ & $06: 46$ & 44.5 & $16: 46$ & 48.4 & 46.0 & 44.0 & & \\
\hline $11 / 05 / 98$ & $06: 46$ & 46.1 & $13: 16$ & 47.3 & 46.3 & 46.0 & 64.4 & $\begin{array}{l}\text { monitor removed } \\
13: 16 \mathrm{hrs} \text {. }\end{array}$ \\
\hline
\end{tabular}




\section{Summary of Daily Temperature Values for the Continuous Instream Monitor Placed at Lewis \& Clark Trail State Park, Touchet River, 1998}

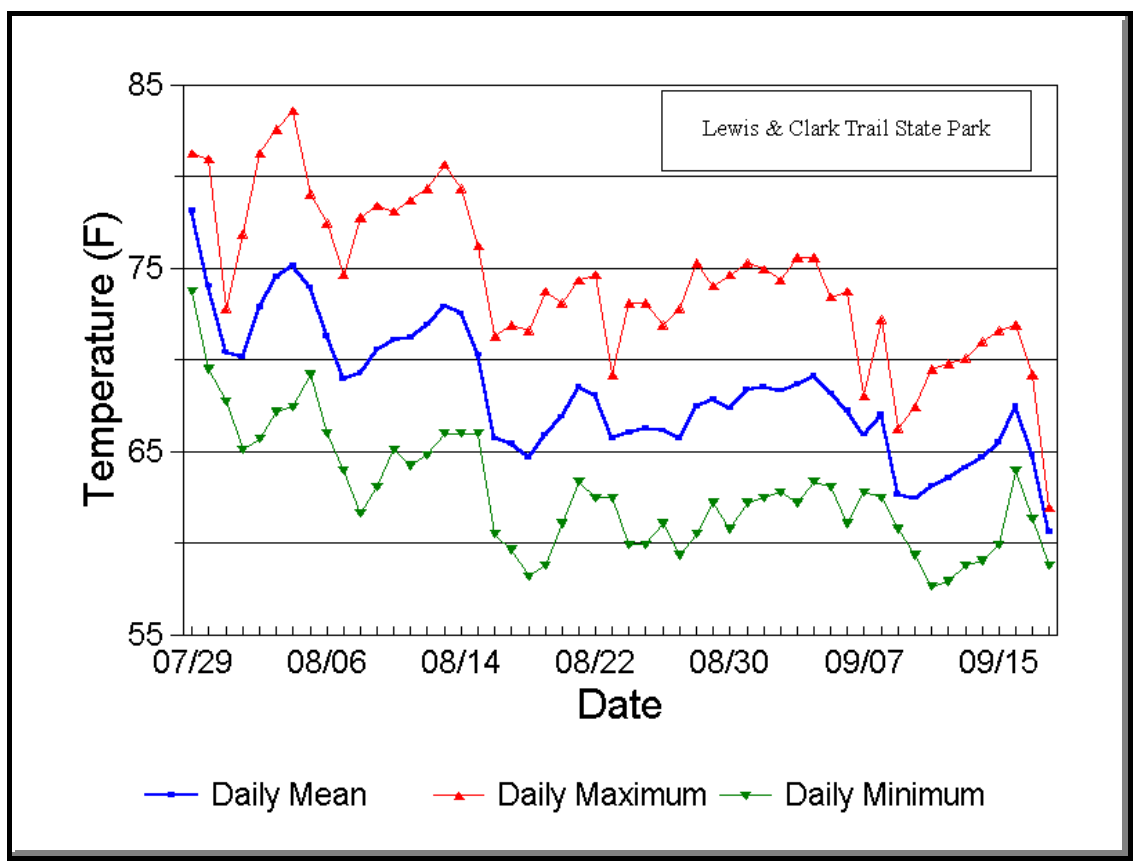

Summary of Daily Temperature Values for the Continuous Instream Monitor Placed at Lewis \& Clark Trail State Park, Touchet River, 1998.

\begin{tabular}{lrrrrrrl}
\hline Date & $\begin{array}{r}\text { Min } \\
\text { Time }\end{array}$ & $\begin{array}{r}\text { Min } \\
\text { Temp (F) }\end{array}$ & $\begin{array}{r}\text { Max } \\
\text { Time }\end{array}$ & $\begin{array}{r}\text { Max } \\
\text { Temp (F) }\end{array}$ & $\begin{array}{r}\text { Daily } \\
\text { Mean }\end{array}$ & $\begin{array}{r}\text { Daily } \\
\text { Mode }\end{array}$ & Notes \\
\hline $07 / 29 / 98$ & $23: 55$ & 73.7 & $17: 25$ & 81.3 & 78.1 & 81.0 & monitor installed 17:25 hrs. \\
$07 / 30 / 98$ & $06: 55$ & 69.5 & $16: 25$ & 80.9 & 74.0 & 70.0 & \\
$07 / 31 / 98$ & $08: 55$ & 67.7 & $14: 25$ & 72.8 & 70.4 & 73.0 & \\
$08 / 01 / 98$ & $06: 55$ & 65.1 & $17: 25$ & 76.8 & 70.1 & 66.0 & \\
$08 / 02 / 98$ & $06: 25$ & 65.7 & $17: 25$ & 81.3 & 72.9 & 66.0 & \\
$08 / 03 / 98$ & $06: 55$ & 67.2 & $17: 25$ & 82.6 & 74.5 & 68.0 & \\
$08 / 04 / 98$ & $07: 25$ & 67.4 & $17: 25$ & 83.6 & 75.1 & 83.0 & \\
$08 / 05 / 98$ & $06: 55$ & 69.2 & $17: 25$ & 79.0 & 74.0 & 70.0 & \\
$08 / 06 / 98$ & $06: 55$ & 66.0 & $17: 25$ & 77.5 & 71.3 & 77.0 & \\
$08 / 07 / 98$ & $06: 25$ & 63.9 & $16: 55$ & 74.6 & 69.0 & 74.0 & \\
$08 / 08 / 98$ & $07: 25$ & 61.6 & $17: 25$ & 77.8 & 69.3 & 62.0 & \\
$08 / 09 / 98$ & $06: 55$ & 63.1 & $17: 55$ & 78.4 & 70.6 & 78.0 & \\
$08 / 10 / 98$ & $06: 25$ & 65.1 & $17: 55$ & 78.1 & 71.1 & 65.0 & \\
$08 / 11 / 98$ & $06: 55$ & 64.2 & $16: 55$ & 78.7 & 71.2 & 65.0 & \\
$08 / 12 / 98$ & $07: 25$ & 64.8 & $16: 55$ & 79.3 & 71.9 & 79.0 & \\
$08 / 13 / 98$ & $07: 25$ & 66.0 & $17: 25$ & 80.6 & 72.9 & 80.0 &
\end{tabular}


Summary of Daily Temperature Values for the Continuous Instream Monitor Placed at Lewis \& Clark Trail State Park, Touchet River, 1998.

\begin{tabular}{|c|c|c|c|c|c|c|c|}
\hline Date & $\begin{array}{r}\text { Min } \\
\text { Time } \\
\end{array}$ & $\begin{array}{r}\text { Min } \\
\text { Temp (F) } \\
\end{array}$ & $\begin{array}{r}\text { Max } \\
\text { Time } \\
\end{array}$ & $\begin{array}{r}\text { Max } \\
\text { Temp (F) } \\
\end{array}$ & $\begin{array}{l}\text { Daily } \\
\text { Mean }\end{array}$ & $\begin{array}{l}\text { Daily } \\
\text { Mode }\end{array}$ & Notes \\
\hline 08/14/98 & $06: 55$ & 66.0 & $17: 25$ & 79.3 & 72.5 & 79.0 & \\
\hline $08 / 15 / 98$ & $06: 55$ & 66.0 & $16: 25$ & 76.2 & 70.3 & 67.0 & \\
\hline 08/16/98 & $07: 25$ & 60.5 & $17: 25$ & 71.3 & 65.7 & 65.0 & \\
\hline 08/17/98 & $06: 55$ & 59.6 & $17: 25$ & 71.9 & 65.4 & 60.0 & \\
\hline 08/18/98 & $07: 25$ & 58.2 & $17: 55$ & 71.6 & 64.7 & 60.0 & \\
\hline 08/19/98 & $06: 55$ & 58.8 & $16: 55$ & 73.7 & 65.9 & 59.0 & \\
\hline 08/20/98 & $07: 25$ & 61.1 & $16: 56$ & 73.1 & 66.9 & 73.0 & \\
\hline $08 / 21 / 98$ & $07: 26$ & 63.4 & $16: 26$ & 74.3 & 68.5 & 74.0 & \\
\hline $08 / 22 / 98$ & $07: 26$ & 62.5 & $16: 56$ & 74.6 & 68.1 & 63.0 & \\
\hline $08 / 23 / 98$ & $09: 26$ & 62.5 & $14: 56$ & 69.2 & 65.8 & 69.0 & \\
\hline $08 / 24 / 98$ & $07: 26$ & 59.9 & $17: 26$ & 73.1 & 66.0 & 60.0 & \\
\hline $08 / 25 / 98$ & $07: 26$ & 59.9 & $16: 56$ & 73.1 & 66.3 & 60.0 & \\
\hline $08 / 26 / 98$ & $07: 26$ & 61.1 & $16: 26$ & 71.9 & 66.2 & 62.0 & \\
\hline $08 / 27 / 98$ & $07: 26$ & 59.4 & $17: 26$ & 72.8 & 65.8 & 60.0 & \\
\hline $08 / 28 / 98$ & $07: 26$ & 60.5 & $17: 26$ & 75.3 & 67.4 & 62.0 & \\
\hline 08/29/98 & $06: 56$ & 62.2 & $16: 26$ & 74.0 & 67.8 & 65.0 & \\
\hline 08/30/98 & $07: 26$ & 60.8 & $17: 26$ & 74.6 & 67.4 & 61.0 & \\
\hline $08 / 31 / 98$ & $06: 56$ & 62.2 & $17: 26$ & 75.3 & 68.4 & 75.0 & \\
\hline 09/01/98 & $07: 26$ & 62.5 & $16: 56$ & 75.0 & 68.6 & 63.0 & \\
\hline 09/02/98 & $07: 26$ & 62.8 & $18: 26$ & 74.3 & 68.3 & 74.0 & \\
\hline 09/03/98 & $07: 26$ & 62.2 & $17: 26$ & 75.6 & 68.7 & 63.0 & \\
\hline $09 / 04 / 98$ & $07: 26$ & 63.4 & $17: 26$ & 75.6 & 69.1 & 64.0 & \\
\hline 09/05/98 & $07: 56$ & 63.1 & $16: 56$ & 73.4 & 68.2 & 73.0 & \\
\hline 09/06/98 & $07: 26$ & 61.1 & $17: 26$ & 73.7 & 67.2 & 62.0 & \\
\hline 09/07/98 & $06: 56$ & 62.8 & $18: 26$ & 68.0 & 65.9 & 67.0 & \\
\hline 09/08/98 & $07: 26$ & 62.5 & $15: 56$ & 72.2 & 67.0 & 63.0 & \\
\hline 09/09/98 & $10: 26$ & 60.8 & $00: 26$ & 66.3 & 62.7 & 62.0 & \\
\hline 09/10/98 & $07: 56$ & 59.4 & $17: 26$ & 67.4 & 62.5 & 60.0 & \\
\hline $09 / 11 / 98$ & $06: 56$ & 57.6 & $17: 56$ & 69.5 & 63.1 & 58.0 & \\
\hline $09 / 12 / 98$ & $07: 56$ & 57.9 & $17: 26$ & 69.8 & 63.5 & 58.0 & \\
\hline 09/13/98 & $07: 26$ & 58.8 & $17: 26$ & 70.1 & 64.1 & 59.0 & \\
\hline $09 / 14 / 98$ & $07: 56$ & 59.1 & $16: 56$ & 71.0 & 64.7 & 60.0 & \\
\hline $09 / 15 / 98$ & $06: 56$ & 59.9 & $17: 26$ & 71.6 & 65.5 & 60.0 & \\
\hline 09/16/98 & $06: 56$ & 63.9 & $17: 56$ & 71.9 & 67.4 & 65.0 & \\
\hline 09/17/98 & $07: 56$ & 61.4 & $16: 26$ & 69.2 & 64.9 & 62.0 & \\
\hline $09 / 18 / 98$ & 07:56 & 58.8 & $00: 26$ & 61.9 & 60.6 & 59.0 & monitor lost 12:59 hrs. \\
\hline
\end{tabular}




\section{Summary of Daily Temperature Values Measured by a Continuous Instream Monitor Placed at McDonald Rd., Walla Walla River, 1998}

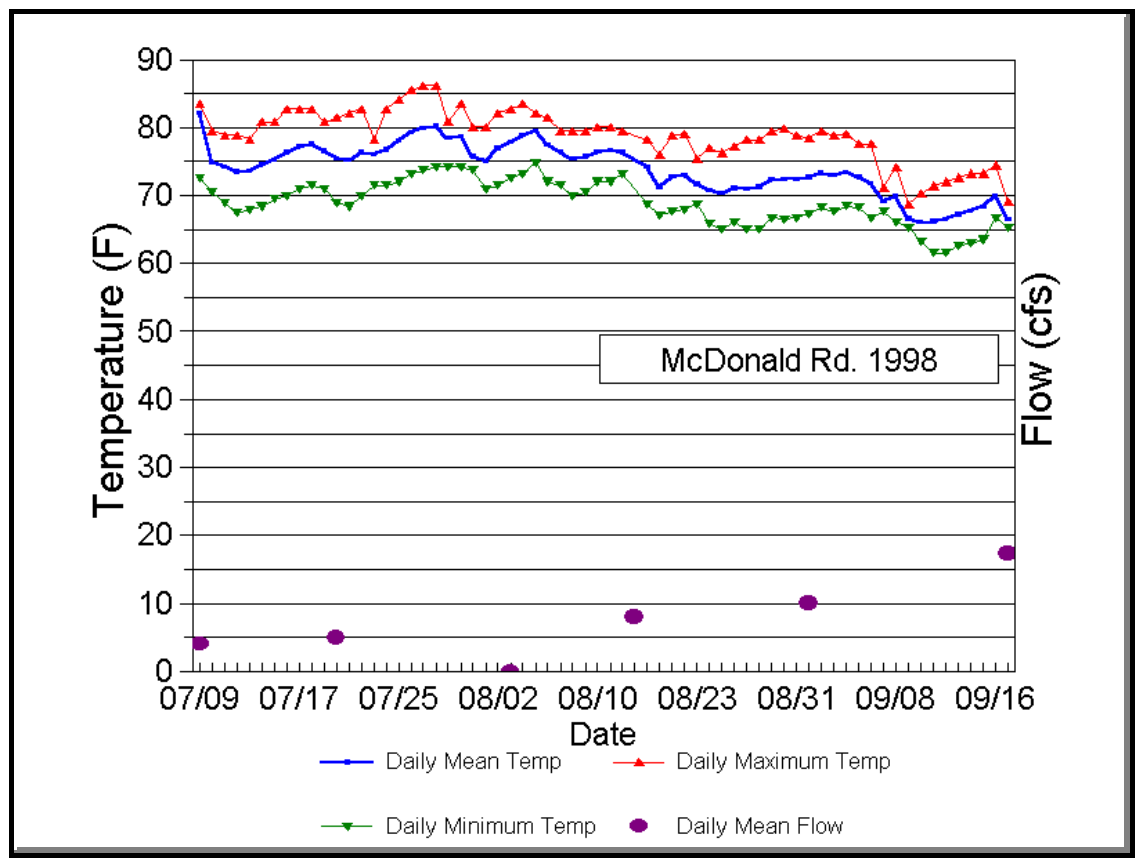

Summary of Daily Temperature Values Measured by a Continuous Instream Monitor Placed at McDonald Rd., Walla Walla River, 1998. Periodic manual flow measurements at the same location.

\begin{tabular}{|c|c|c|c|c|c|c|c|c|}
\hline Date & $\begin{array}{c}\text { Min } \\
\text { Time } \\
\end{array}$ & $\begin{array}{r}\text { Min } \\
\text { Temp (F) } \\
\end{array}$ & $\begin{array}{r}\text { Max } \\
\text { Time } \\
\end{array}$ & $\begin{array}{r}\text { Max } \\
\text { Temp (F) } \\
\end{array}$ & $\begin{array}{r}\text { Daily } \\
\text { Mean } \\
\end{array}$ & $\begin{array}{l}\text { Daily } \\
\text { Mode } \\
\end{array}$ & $\begin{array}{r}\text { Flow } \\
\text { (cfs) }\end{array}$ & Notes \\
\hline $07 / 09 / 98$ & 04:00 & 72.6 & 08:00 & 83.5 & 82.1 & & 4.1 & monitor installed \\
\hline 07/10/98 & 08:00 & 70.5 & 08:00 & 79.6 & 74.9 & & & $16: 00 \mathrm{hrs}$ \\
\hline 07/11/98 & 08:00 & 68.9 & 08:00 & 79.0 & 74.3 & & & \\
\hline $07 / 12 / 98$ & 08:00 & 67.4 & 08:00 & 79.0 & 73.5 & & & \\
\hline 07/13/98 & 08:00 & 67.9 & 08:00 & 78.4 & 73.6 & & & \\
\hline $07 / 14 / 98$ & 08:00 & 68.4 & 08:00 & 80.8 & 74.6 & & & \\
\hline $07 / 15 / 98$ & 08:00 & 69.4 & 08:00 & 80.8 & 75.2 & & & \\
\hline 07/16/98 & 08:00 & 70.0 & 08:00 & 82.8 & 76.3 & & & \\
\hline 07/17/98 & 08:00 & 71.0 & 08:00 & 82.8 & 77.2 & & & \\
\hline 07/18/98 & 08:00 & 71.5 & 08:00 & 82.8 & 77.6 & & & \\
\hline 07/19/98 & 08:00 & 71.0 & 08:00 & 80.8 & 76.6 & & & \\
\hline 07/20/98 & 08:00 & 68.9 & 08:00 & 81.5 & 75.5 & & 4.9 & \\
\hline $07 / 21 / 98$ & 08:00 & 68.4 & 08:00 & 82.1 & 75.2 & & & \\
\hline $07 / 22 / 98$ & 08:00 & 70.0 & 08:00 & 82.8 & 76.4 & & & \\
\hline 07/23/98 & 08:00 & 71.5 & 08:00 & 78.4 & 76.0 & & & \\
\hline $07 / 24 / 98$ & 08:00 & 71.5 & 08:00 & 82.8 & 76.8 & & & \\
\hline
\end{tabular}


Summary of Daily Temperature Values Measured by a Continuous Instream Monitor Placed at McDonald Rd., Walla Walla River, 1998. Periodic manual flow measurements at the same location.

\begin{tabular}{|c|c|c|c|c|c|c|c|c|}
\hline Date & $\begin{array}{r}\text { Min } \\
\text { Time }\end{array}$ & $\begin{array}{r}\text { Min } \\
\text { Temp (F) }\end{array}$ & $\begin{array}{r}\text { Max } \\
\text { Time }\end{array}$ & $\begin{array}{r}\text { Max } \\
\text { Temp (F) } \\
\end{array}$ & $\begin{array}{l}\text { Daily } \\
\text { Mean }\end{array}$ & $\begin{array}{l}\text { Daily } \\
\text { Mode }\end{array}$ & $\begin{array}{r}\text { Flow } \\
\text { (cfs) }\end{array}$ & Notes \\
\hline $07 / 25 / 98$ & 08:00 & 72.1 & 08:00 & 84.1 & 78.1 & & & \\
\hline 07/26/98 & 08:00 & 73.2 & 08:00 & 85.5 & 79.3 & & & \\
\hline 07/27/98 & 08:00 & 73.7 & 08:00 & 86.2 & 80.0 & & & \\
\hline 07/28/98 & 08:00 & 74.3 & 08:00 & 86.2 & 80.3 & & & \\
\hline 07/29/98 & 08:00 & 74.3 & 08:00 & 80.8 & 78.4 & & & \\
\hline 07/30/98 & 08:00 & 74.3 & 08:00 & 83.5 & 78.6 & & & \\
\hline $07 / 31 / 98$ & $12: 00$ & 73.7 & $12: 00$ & 80.2 & 75.8 & & & \\
\hline 08/01/98 & 08:00 & 71.0 & 08:00 & 80.2 & 75.0 & & & \\
\hline $08 / 02 / 98$ & 08:00 & 71.5 & 08:00 & 82.1 & 77.0 & & & \\
\hline 08/03/98 & 08:00 & 72.6 & 08:00 & 82.8 & 77.9 & & 0.0 & \\
\hline 08/04/98 & 08:00 & 73.2 & 08:00 & 83.5 & 78.9 & & & \\
\hline 08/05/98 & 08:00 & 74.8 & 08:00 & 82.1 & 79.5 & & & \\
\hline 08/06/98 & 08:00 & 72.1 & 08:00 & 81.5 & 77.5 & & & \\
\hline 08/07/98 & 08:00 & 71.5 & 08:00 & 79.6 & 76.4 & & & \\
\hline 08/08/98 & 08:00 & 70.0 & 08:00 & 79.6 & 75.4 & & & \\
\hline 08/09/98 & 08:00 & 70.5 & 08:00 & 79.6 & 75.8 & & & \\
\hline 08/10/98 & 08:00 & 72.1 & 08:00 & 80.2 & 76.4 & & & \\
\hline 08/11/98 & 08:00 & 72.1 & 08:00 & 80.2 & 76.7 & & & \\
\hline $08 / 12 / 98$ & 08:00 & 73.2 & $12: 00$ & 79.6 & 76.4 & & & $\begin{array}{l}\text { WDOE monitor } \\
\text { removed 12:00 hrs. }\end{array}$ \\
\hline 08/17/98 & & & & & & & 8.0 & \\
\hline 08/19/98 & $10: 27$ & 68.8 & $16: 27$ & 78.2 & 74.3 & 78.0 & & WDFW monitor \\
\hline 08/20/98 & $06: 57$ & 67.1 & $15: 27$ & 76.1 & 71.3 & 71.0 & & installed 10:27 hrs. \\
\hline $08 / 21 / 98$ & $06: 57$ & 67.6 & $16: 57$ & 78.9 & 72.7 & 68.0 & & \\
\hline $08 / 22 / 98$ & 07:57 & 67.9 & $16: 57$ & 79.2 & 73.0 & 69.0 & & \\
\hline $08 / 23 / 98$ & $09: 27$ & 68.8 & $15: 57$ & 75.4 & 71.7 & 69.0 & & \\
\hline $08 / 24 / 98$ & 07:57 & 65.9 & $16: 57$ & 77.0 & 70.8 & 66.0 & & \\
\hline $08 / 25 / 98$ & $07: 57$ & 65.0 & $16: 57$ & 76.4 & 70.3 & 66.0 & & \\
\hline 08/26/98 & 08:27 & 66.2 & $16: 57$ & 77.3 & 71.0 & 66.0 & & \\
\hline 08/27/98 & $07: 27$ & 65.0 & $17: 27$ & 78.2 & 71.0 & 65.0 & & \\
\hline $08 / 28 / 98$ & $07: 27$ & 65.0 & $16: 57$ & 78.2 & 71.3 & 78.0 & & \\
\hline 08/29/98 & 07:57 & 66.8 & $16: 27$ & 79.5 & 72.3 & 67.0 & & \\
\hline 08/30/98 & $07: 27$ & 66.5 & $17: 27$ & 79.8 & 72.4 & 67.0 & & \\
\hline $08 / 31 / 98$ & $08: 27$ & 66.8 & $16: 27$ & 78.9 & 72.4 & 67.0 & & \\
\hline 09/01/98 & 08:27 & 67.4 & $17: 25$ & 78.6 & 72.7 & 71.0 & 10.0 & \\
\hline 09/02/98 & $08: 25$ & 68.2 & $16: 25$ & 79.5 & 73.4 & 69.0 & & \\
\hline 09/03/98 & 08:55 & 67.6 & $15: 55$ & 78.9 & 73.0 & 68.0 & & \\
\hline 09/04/98 & $07: 55$ & 68.5 & $16: 55$ & 79.2 & 73.4 & 69.0 & & \\
\hline
\end{tabular}


Summary of Daily Temperature Values Measured by a Continuous Instream Monitor Placed at McDonald Rd., Walla Walla River, 1998. Periodic manual flow measurements at the same location.

\begin{tabular}{lcccccccc}
\hline Date & $\begin{array}{r}\text { Min } \\
\text { Time }\end{array}$ & $\begin{array}{r}\text { Min } \\
\text { Temp (F) }\end{array}$ & $\begin{array}{r}\text { Max } \\
\text { Time }\end{array}$ & $\begin{array}{r}\text { Max } \\
\text { Temp }(\mathbf{F})\end{array}$ & $\begin{array}{r}\text { Daily } \\
\text { Mean }\end{array}$ & $\begin{array}{c}\text { Daily } \\
\text { Mode }\end{array}$ & $\begin{array}{r}\text { Flow } \\
(\mathbf{c f s})\end{array}$ Notes \\
\hline $09 / 05 / 98$ & $07: 55$ & 68.2 & $16: 25$ & 77.6 & 72.8 & 69.0 & & \\
$09 / 06 / 98$ & $08: 55$ & 66.8 & $16: 55$ & 77.6 & 71.8 & 67.0 & & \\
$09 / 07 / 98$ & $07: 25$ & 67.6 & $00: 25$ & 71.2 & 69.2 & 69.0 & & \\
$09 / 08 / 98$ & $07: 55$ & 66.2 & $15: 25$ & 74.2 & 69.8 & 69.0 & & \\
$09 / 09 / 98$ & $09: 25$ & 65.3 & $00: 55$ & 68.8 & 66.6 & 66.0 & & \\
$09 / 10 / 98$ & $08: 25$ & 63.3 & $16: 25$ & 70.3 & 66.1 & 64.0 & & \\
$09 / 11 / 98$ & $08: 25$ & 61.6 & $16: 55$ & 71.5 & 66.2 & 62.0 & & \\
$09 / 12 / 98$ & $07: 25$ & 61.6 & $16: 25$ & 72.1 & 66.5 & 62.0 & & \\
$09 / 13 / 98$ & $08: 25$ & 62.7 & $15: 55$ & 72.7 & 67.2 & 63.0 & & \\
$09 / 14 / 98$ & $08: 25$ & 63.0 & $15: 55$ & 73.3 & 67.7 & 64.0 & & \\
$09 / 15 / 98$ & $07: 55$ & 63.6 & $16: 55$ & 73.3 & 68.3 & 64.0 & & \\
$09 / 16 / 98$ & $08: 55$ & 66.8 & $15: 55$ & 74.5 & 69.9 & 67.0 & & \\
$09 / 17 / 98$ & $07: 25$ & 65.3 & $00: 25$ & 69.1 & 66.5 & 66.0 & 17.3 & monitor lost 11:25 \\
\hline
\end{tabular}




\section{Summary of Daily Temperature Values for the Continuous Instream Monitor Placed at Simms Road, Touchet River, 1998}

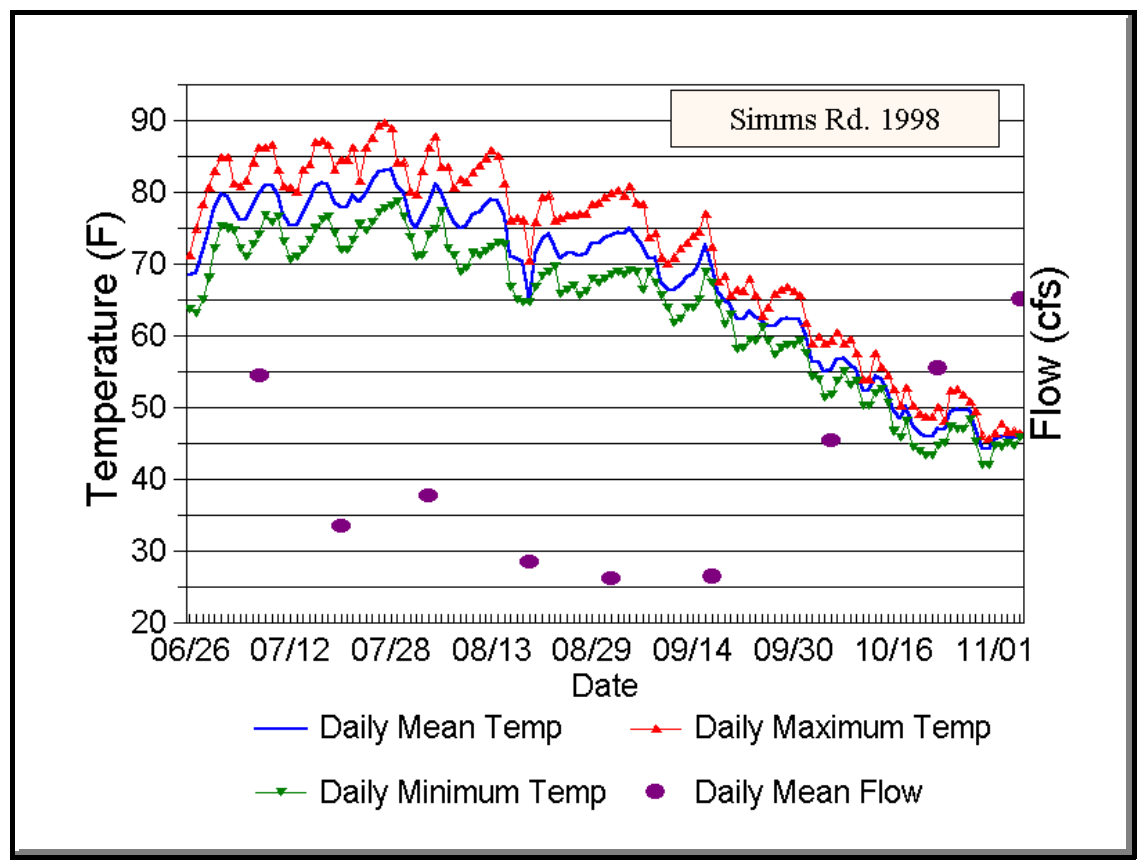

Summary of Daily Temperature Values for the Continuous Instream Monitor Placed at Simms Road, Touchet River, 1998. Manual flows also measured at the same location.

\begin{tabular}{|c|c|c|c|c|c|c|c|c|}
\hline Date & $\begin{array}{r}\text { Min } \\
\text { Time }\end{array}$ & $\begin{array}{r}\text { Min } \\
\text { Temp (F) }\end{array}$ & $\begin{array}{r}\text { Max } \\
\text { Time } \\
\end{array}$ & $\begin{array}{r}\text { Max } \\
\text { Temp (F) } \\
\end{array}$ & $\begin{array}{r}\text { Daily } \\
\text { Mean (F) } \\
\end{array}$ & $\begin{array}{l}\text { Daily } \\
\text { Mode }\end{array}$ & $\begin{array}{r}\text { Flows } \\
\text { (cfs) }\end{array}$ & Notes \\
\hline $06 / 26 / 98$ & $10: 44$ & 63.7 & $15: 59$ & 71.3 & 68.4 & 70.0 & & monitor installed \\
\hline $06 / 27 / 98$ & 08:14 & 63.1 & $17: 59$ & 75.0 & 68.8 & 63.0 & & 10:29 hrs \\
\hline $06 / 28 / 98$ & 07:29 & 65.1 & 18:44 & 78.4 & 71.9 & 78.0 & & \\
\hline $06 / 29 / 98$ & $07: 14$ & 68.1 & $17: 29$ & 80.6 & 74.5 & 80.0 & & \\
\hline 06/30/98 & 07:44 & 72.2 & $17: 59$ & 82.9 & 77.7 & 83.0 & & \\
\hline 07/01/98 & 07:29 & 75.3 & $17: 44$ & 84.9 & 79.8 & 76.0 & & \\
\hline 07/02/98 & 07:44 & 75.0 & $15: 29$ & 84.9 & 79.4 & 79.0 & & \\
\hline 07/03/98 & 07:59 & 74.7 & $17: 29$ & 81.3 & 77.7 & 77.0 & & \\
\hline 07/04/98 & 08:29 & 72.2 & $17: 59$ & 81.0 & 76.2 & 73.0 & & \\
\hline 07/05/98 & 07:44 & 71.0 & $17: 59$ & 81.6 & 76.2 & 81.0 & & \\
\hline 07/06/98 & 07:44 & 72.8 & 18:14 & 84.2 & 78.2 & 73.0 & & \\
\hline 07/07/98 & 06:59 & 74.0 & 18:14 & 86.2 & 79.9 & 86.0 & 54.4 & \\
\hline 07/08/98 & 07:59 & 76.8 & $16: 59$ & 86.2 & 81.0 & 77.0 & & \\
\hline 07/09/98 & 07:29 & 75.9 & $17: 14$ & 86.6 & 80.8 & 77.0 & & \\
\hline 07/10/98 & $10: 14$ & 76.5 & $17: 59$ & 83.2 & 79.8 & 77.0 & & \\
\hline 07/11/98 & 08:59 & 73.1 & $16: 59$ & 81.0 & 76.8 & 76.0 & & \\
\hline $07 / 12 / 98$ & 07:59 & 70.7 & $16: 59$ & 80.6 & 75.3 & 71.0 & & \\
\hline
\end{tabular}


Summary of Daily Temperature Values for the Continuous Instream Monitor Placed at Simms Road, Touchet River, 1998. Manual flows also measured at the same location.

\begin{tabular}{|c|c|c|c|c|c|c|c|c|}
\hline Date & $\begin{array}{c}\text { Min } \\
\text { Time }\end{array}$ & $\begin{array}{r}\text { Min } \\
\text { Temp (F) }\end{array}$ & $\begin{array}{c}\text { Max } \\
\text { Time }\end{array}$ & $\begin{array}{r}\text { Max } \\
\text { Temp (F) }\end{array}$ & $\begin{array}{r}\text { Daily } \\
\text { Mean (F) }\end{array}$ & $\begin{array}{l}\text { Daily } \\
\text { Mode }\end{array}$ & $\begin{array}{r}\text { Flows } \\
\text { (cfs) }\end{array}$ & Notes \\
\hline $07 / 13 / 98$ & $07: 59$ & 71.0 & $17: 29$ & 80.0 & 75.4 & 79.0 & & \\
\hline $07 / 14 / 98$ & $08: 29$ & 71.9 & $17: 44$ & 83.2 & 77.1 & 72.0 & & \\
\hline $07 / 15 / 98$ & $07: 44$ & 73.4 & $16: 59$ & 83.9 & 78.7 & 84.0 & & \\
\hline $07 / 16 / 98$ & $07: 29$ & 75.0 & $17: 44$ & 86.9 & 80.6 & 77.0 & & \\
\hline $07 / 17 / 98$ & $07: 44$ & 76.2 & $17: 59$ & 87.3 & 81.4 & 87.0 & & \\
\hline $07 / 18 / 98$ & $07: 59$ & 76.5 & $17: 14$ & 86.6 & 81.0 & 77.0 & & \\
\hline 07/19/98 & $07: 44$ & 74.3 & $18: 14$ & 83.2 & 78.5 & 83.0 & & \\
\hline $07 / 20 / 98$ & $06: 59$ & 71.9 & $18: 11$ & 84.6 & 77.8 & 73.0 & 33.5 & \\
\hline $07 / 21 / 98$ & $07: 11$ & 71.9 & $17: 41$ & 84.6 & 77.9 & 72.0 & & \\
\hline $07 / 22 / 98$ & $07: 11$ & 73.4 & $16: 56$ & 86.2 & 79.6 & 86.0 & & \\
\hline $07 / 23 / 98$ & $08: 26$ & 75.6 & $17: 41$ & 81.6 & 78.6 & 79.0 & & \\
\hline $07 / 24 / 98$ & $06: 56$ & 74.7 & $17: 41$ & 86.2 & 79.9 & 75.0 & & \\
\hline $07 / 25 / 98$ & $07: 11$ & 75.9 & $17: 56$ & 87.6 & 81.5 & 76.0 & & \\
\hline $07 / 26 / 98$ & $06: 56$ & 77.2 & $17: 26$ & 89.3 & 82.9 & 89.0 & & \\
\hline $07 / 27 / 98$ & $07: 11$ & 77.8 & $17: 26$ & 89.7 & 83.1 & 78.0 & & \\
\hline $07 / 28 / 98$ & $06: 56$ & 78.1 & $18: 26$ & 89.0 & 83.3 & 79.0 & & \\
\hline $07 / 29 / 98$ & $08: 26$ & 78.7 & $00: 11$ & 84.2 & 81.0 & 81.0 & & \\
\hline $07 / 30 / 98$ & $07: 11$ & 76.5 & $16: 26$ & 84.2 & 80.0 & 77.0 & & \\
\hline $07 / 31 / 98$ & $23: 56$ & 73.7 & $00: 11$ & 80.0 & 76.2 & 76.0 & & \\
\hline $08 / 01 / 98$ & $08: 11$ & 71.0 & $17: 26$ & 79.7 & 74.9 & 73.0 & & \\
\hline $08 / 02 / 98$ & $07: 56$ & 71.3 & $18: 26$ & 82.9 & 76.7 & 72.0 & & \\
\hline $08 / 03 / 98$ & $06: 41$ & 74.0 & $18: 30$ & 86.2 & 78.4 & 74.0 & 37.7 & \\
\hline $08 / 04 / 98$ & $07: 30$ & 74.9 & $18: 00$ & 87.9 & 81.1 & 76.0 & & \\
\hline $08 / 05 / 98$ & $07: 30$ & 77.4 & $16: 00$ & 83.5 & 80.2 & 78.0 & & \\
\hline 08/06/98 & $07: 30$ & 72.1 & $17: 30$ & 83.5 & 77.4 & 83.0 & & \\
\hline 08/07/98 & $08: 30$ & 71.2 & $18: 00$ & 80.6 & 75.8 & 72.0 & & \\
\hline 08/08/98 & 07:00 & 68.8 & $17: 30$ & 81.8 & 75.1 & 69.0 & & \\
\hline $08 / 09 / 98$ & $07: 30$ & 69.4 & $17: 30$ & 81.5 & 75.4 & 70.0 & & \\
\hline 08/10/98 & 07:00 & 71.5 & $18: 00$ & 82.8 & 76.9 & 72.0 & & \\
\hline $08 / 11 / 98$ & 07:00 & 71.2 & $17: 30$ & 83.8 & 77.3 & 72.0 & & \\
\hline $08 / 12 / 98$ & $07: 30$ & 71.8 & $17: 00$ & 84.8 & 78.2 & 72.0 & & \\
\hline $08 / 13 / 98$ & $07: 30$ & 72.4 & $17: 30$ & 85.8 & 79.1 & 73.0 & & \\
\hline $08 / 14 / 98$ & $07: 30$ & 73.0 & $17: 30$ & 85.1 & 78.9 & 82.0 & & \\
\hline $08 / 15 / 98$ & $23: 30$ & 72.7 & $16: 00$ & 81.2 & 76.6 & 74.0 & & \\
\hline $08 / 16 / 98$ & $07: 30$ & 66.8 & $17: 30$ & 76.1 & 71.2 & 67.0 & & \\
\hline $08 / 17 / 98$ & $07: 30$ & 65.0 & $18: 00$ & 76.5 & 70.6 & 76.0 & & \\
\hline $08 / 18 / 98$ & 08:00 & 64.8 & $17: 00$ & 76.1 & 70.3 & 65.0 & & \\
\hline $08 / 19 / 98$ & 08:00 & 64.8 & $17: 56$ & 70.5 & 65.0 & 65.0 & 28.4 & \\
\hline $08 / 20 / 98$ & $06: 56$ & 66.8 & $16: 56$ & 75.8 & 71.3 & 67.0 & & \\
\hline
\end{tabular}


Summary of Daily Temperature Values for the Continuous Instream Monitor Placed at Simms Road, Touchet River, 1998. Manual flows also measured at the same location.

\begin{tabular}{|c|c|c|c|c|c|c|c|c|}
\hline Date & $\begin{array}{c}\text { Min } \\
\text { Time }\end{array}$ & $\begin{array}{r}\text { Min } \\
\text { Temp (F) }\end{array}$ & $\begin{array}{c}\text { Max } \\
\text { Time }\end{array}$ & $\begin{array}{r}\text { Max } \\
\text { Temp (F) }\end{array}$ & $\begin{array}{r}\text { Daily } \\
\text { Mean (F) }\end{array}$ & $\begin{array}{l}\text { Daily } \\
\text { Mode }\end{array}$ & $\begin{array}{r}\text { Flows } \\
\text { (cfs) }\end{array}$ & Notes \\
\hline $08 / 21 / 98$ & $07: 26$ & 68.3 & $17: 56$ & 79.3 & 73.4 & 69.0 & & \\
\hline $08 / 22 / 98$ & $07: 26$ & 68.8 & $17: 56$ & 79.6 & 74.2 & 69.0 & & \\
\hline $08 / 23 / 98$ & $08: 26$ & 69.7 & $15: 26$ & 76.1 & 72.4 & 70.0 & & \\
\hline $08 / 24 / 98$ & $07: 26$ & 65.9 & $17: 26$ & 76.5 & 70.7 & 67.0 & & \\
\hline $08 / 25 / 98$ & $07: 56$ & 66.5 & $17: 56$ & 76.8 & 71.4 & 67.0 & & \\
\hline $08 / 26 / 98$ & $07: 56$ & 67.1 & $17: 56$ & 76.8 & 71.6 & 76.0 & & \\
\hline 08/27/98 & $07: 56$ & 65.6 & $17: 56$ & 77.1 & 71.1 & 66.0 & & \\
\hline $08 / 28 / 98$ & $07: 26$ & 66.2 & $17: 56$ & 77.1 & 71.4 & 76.0 & & \\
\hline 08/29/98 & $06: 56$ & 68.0 & $16: 56$ & 78.3 & 72.9 & 69.0 & & \\
\hline 08/30/98 & $07: 56$ & 67.4 & $16: 56$ & 78.6 & 72.9 & 69.0 & & \\
\hline $08 / 31 / 98$ & $07: 26$ & 68.0 & $17: 56$ & 79.3 & 73.6 & 79.0 & & \\
\hline 09/01/98 & $06: 56$ & 68.6 & $17: 26$ & 79.9 & 74.1 & 69.0 & 26.2 & \\
\hline 09/02/98 & $07: 56$ & 68.8 & $17: 56$ & 80.2 & 74.4 & 80.0 & & \\
\hline 09/03/98 & $07: 56$ & 68.6 & $17: 56$ & 79.6 & 74.2 & 69.0 & & \\
\hline 09/04/98 & $07: 56$ & 69.1 & $17: 26$ & 80.9 & 74.9 & 70.0 & & \\
\hline 09/05/98 & $07: 56$ & 68.8 & $16: 56$ & 78.6 & 73.8 & 78.0 & & \\
\hline 09/06/98 & $07: 26$ & 66.5 & $17: 56$ & 78.3 & 72.5 & 78.0 & & \\
\hline 09/07/98 & $06: 56$ & 68.8 & $00: 26$ & 73.7 & 70.6 & 71.0 & & \\
\hline 09/08/98 & $07: 56$ & 67.4 & $15: 56$ & 74.3 & 70.9 & 74.0 & & \\
\hline 09/09/98 & $22: 56$ & 65.6 & $00: 26$ & 70.9 & 67.3 & 67.0 & & \\
\hline 09/10/98 & $07: 56$ & 63.9 & $17: 26$ & 70.0 & 66.4 & 64.0 & & \\
\hline 09/11/98 & $08: 26$ & 61.9 & $16: 56$ & 70.9 & 66.3 & 62.0 & & \\
\hline 09/12/98 & $07: 56$ & 62.4 & $17: 26$ & 72.1 & 67.0 & 63.0 & & \\
\hline 09/13/98 & $08: 26$ & 63.9 & $17: 56$ & 73.0 & 68.2 & 64.0 & & \\
\hline 09/14/98 & $08: 26$ & 63.9 & $17: 56$ & 74.0 & 68.6 & 64.0 & & \\
\hline 09/15/98 & $07: 56$ & 65.0 & $18: 26$ & 74.6 & 69.8 & 66.0 & & \\
\hline 09/16/98 & $08: 26$ & 68.8 & $17: 56$ & 77.1 & 72.6 & 69.0 & & \\
\hline 09/17/98 & $08: 26$ & 67.4 & $00: 26$ & 72.4 & 69.6 & 68.0 & 26.5 & \\
\hline 09/18/98 & $06: 49$ & 64.5 & $15: 49$ & 67.7 & 66.0 & 67.0 & & \\
\hline 09/19/98 & $07: 19$ & 61.6 & $16: 49$ & 68.3 & 64.9 & 62.0 & & \\
\hline 09/20/98 & 08:19 & 63.0 & $17: 19$ & 65.6 & 64.3 & 64.0 & & \\
\hline $09 / 21 / 98$ & 09:19 & 58.2 & $16: 19$ & 66.5 & 62.3 & 60.0 & & \\
\hline $09 / 22 / 98$ & 09:19 & 58.4 & $17: 19$ & 66.2 & 62.2 & 60.0 & & \\
\hline 09/23/98 & 08:49 & 59.6 & $17: 19$ & 68.0 & 63.5 & 60.0 & & \\
\hline $09 / 24 / 98$ & 08:49 & 59.3 & $16: 19$ & 65.6 & 62.6 & 60.0 & & \\
\hline $09 / 25 / 98$ & 08:49 & 61.3 & $15: 49$ & 62.7 & 62.0 & 62.0 & & \\
\hline 09/26/98 & $07: 19$ & 59.3 & $16: 49$ & 63.9 & 61.3 & 60.0 & & \\
\hline 09/27/98 & 08:49 & 57.3 & $16: 49$ & 65.9 & 61.3 & 58.0 & & \\
\hline 09/28/98 & 08:19 & 58.4 & $17: 19$ & 66.5 & 62.3 & 60.0 & & \\
\hline
\end{tabular}


Summary of Daily Temperature Values for the Continuous Instream Monitor Placed at Simms Road, Touchet River, 1998. Manual flows also measured at the same location.

\begin{tabular}{|c|c|c|c|c|c|c|c|c|}
\hline Date & $\begin{array}{r}\text { Min } \\
\text { Time }\end{array}$ & $\begin{array}{r}\text { Min } \\
\text { Temp (F) }\end{array}$ & $\begin{array}{r}\text { Max } \\
\text { Time }\end{array}$ & $\begin{array}{r}\text { Max } \\
\text { Temp (F) } \\
\end{array}$ & $\begin{array}{r}\text { Daily } \\
\text { Mean (F) } \\
\end{array}$ & $\begin{array}{l}\text { Daily } \\
\text { Mode }\end{array}$ & $\begin{array}{r}\text { Flows } \\
\text { (cfs) }\end{array}$ & Notes \\
\hline $09 / 29 / 98$ & $08: 19$ & 58.7 & $16: 49$ & 66.8 & 62.4 & 59.0 & & \\
\hline 09/30/98 & $07: 49$ & 58.7 & $17: 19$ & 66.2 & 62.3 & 59.0 & & \\
\hline $10 / 01 / 98$ & 07:49 & 59.3 & $16: 49$ & 65.6 & 62.2 & 60.0 & & \\
\hline $10 / 02 / 98$ & $23: 49$ & 57.6 & $15: 49$ & 61.9 & 59.9 & 58.0 & & \\
\hline $10 / 03 / 98$ & 09:19 & 54.3 & $16: 49$ & 59.0 & 56.6 & 55.0 & & \\
\hline $10 / 04 / 98$ & $08: 19$ & 54.0 & $16: 19$ & 59.9 & 56.4 & 55.0 & & \\
\hline $10 / 05 / 98$ & $07: 49$ & 51.5 & $16: 49$ & 59.0 & 55.0 & 52.0 & & \\
\hline $10 / 06 / 98$ & 08:49 & 51.7 & $16: 19$ & 59.3 & 55.3 & 54.0 & 45.3 & \\
\hline $10 / 07 / 98$ & $08: 19$ & 53.7 & $15: 49$ & 60.4 & 56.8 & 55.0 & & \\
\hline $10 / 08 / 98$ & 09:19 & 55.1 & $16: 19$ & 59.0 & 56.8 & 56.0 & & \\
\hline $10 / 09 / 98$ & 08:49 & 53.1 & $16: 19$ & 59.6 & 56.0 & 55.0 & & \\
\hline $10 / 10 / 98$ & 08:49 & 53.7 & $16: 49$ & 57.6 & 55.3 & 54.0 & & \\
\hline $10 / 11 / 98$ & 08:49 & 50.3 & $16: 49$ & 54.0 & 52.3 & 53.0 & & \\
\hline $10 / 12 / 98$ & 08:19 & 50.3 & $16: 49$ & 54.0 & 52.2 & 52.0 & & \\
\hline $10 / 13 / 98$ & $06: 19$ & 52.0 & $16: 49$ & 57.6 & 54.3 & 52.0 & & \\
\hline $10 / 14 / 98$ & 08:19 & 52.6 & $16: 49$ & 55.7 & 53.9 & 53.0 & & \\
\hline $10 / 15 / 98$ & $08: 19$ & 50.6 & $15: 49$ & 54.5 & 52.2 & 51.0 & & \\
\hline $10 / 16 / 98$ & 08:49 & 46.7 & $16: 49$ & 52.6 & 49.5 & 50.0 & & \\
\hline $10 / 17 / 98$ & 08:19 & 45.9 & $18: 19$ & 50.3 & 48.4 & 50.0 & & \\
\hline $10 / 18 / 98$ & 08:49 & 48.1 & $15: 49$ & 52.9 & 50.2 & 50.0 & & \\
\hline $10 / 19 / 98$ & 08:49 & 44.5 & $16: 19$ & 50.3 & 47.4 & 48.0 & & \\
\hline $10 / 20 / 98$ & 09:19 & 43.9 & $16: 19$ & 49.2 & 46.6 & 46.0 & & \\
\hline $10 / 21 / 98$ & 09:49 & 43.4 & $16: 19$ & 48.7 & 46.0 & 46.0 & & \\
\hline $10 / 22 / 98$ & $07: 49$ & 43.4 & $17: 19$ & 48.7 & 46.0 & 48.0 & & \\
\hline $10 / 23 / 98$ & 08:49 & 44.8 & $16: 19$ & 50.1 & 47.1 & 45.0 & 55.4 & \\
\hline $10 / 24 / 98$ & 09:19 & 45.1 & $17: 49$ & 48.1 & 46.9 & 48.0 & & \\
\hline $10 / 25 / 98$ & $08: 19$ & 47.3 & $16: 19$ & 52.3 & 49.3 & 48.0 & & \\
\hline $10 / 26 / 98$ & 09:19 & 47.0 & $15: 49$ & 52.6 & 49.7 & 48.0 & & \\
\hline $10 / 27 / 98$ & 08:49 & 47.0 & $16: 49$ & 51.7 & 49.6 & 51.0 & & \\
\hline $10 / 28 / 98$ & 08:49 & 48.4 & $15: 49$ & 50.9 & 49.8 & 50.0 & & \\
\hline $10 / 29 / 98$ & 08:49 & 45.3 & $15: 19$ & 49.5 & 47.4 & 48.0 & & \\
\hline $10 / 30 / 98$ & 08:49 & 42.0 & $16: 19$ & 46.2 & 44.3 & 45.0 & & \\
\hline $10 / 31 / 98$ & 08:19 & 42.0 & $16: 49$ & 45.6 & 44.1 & 45.0 & & \\
\hline $11 / 01 / 98$ & $22: 49$ & 44.8 & $16: 49$ & 46.4 & 45.5 & 45.0 & & \\
\hline $11 / 02 / 98$ & $06: 19$ & 44.5 & $17: 19$ & 47.8 & 45.9 & 45.0 & & \\
\hline $11 / 03 / 98$ & $11: 19$ & 45.1 & $15: 49$ & 46.7 & 45.9 & 46.0 & & \\
\hline $11 / 04 / 98$ & 08:49 & 44.8 & $15: 49$ & 46.7 & 45.7 & 45.0 & & \\
\hline $11 / 05 / 98$ & 01:49 & 45.9 & $13: 49$ & 46.4 & 46.1 & 46.0 & 65.1 & $\begin{array}{l}\text { monitor removed } \\
13: 49 \mathrm{hrs}\end{array}$ \\
\hline
\end{tabular}




\section{Summary of Daily Temperature Values for Continuous Instream Monitor Placed at Dayton Steelhead Pond Intake, 1998}

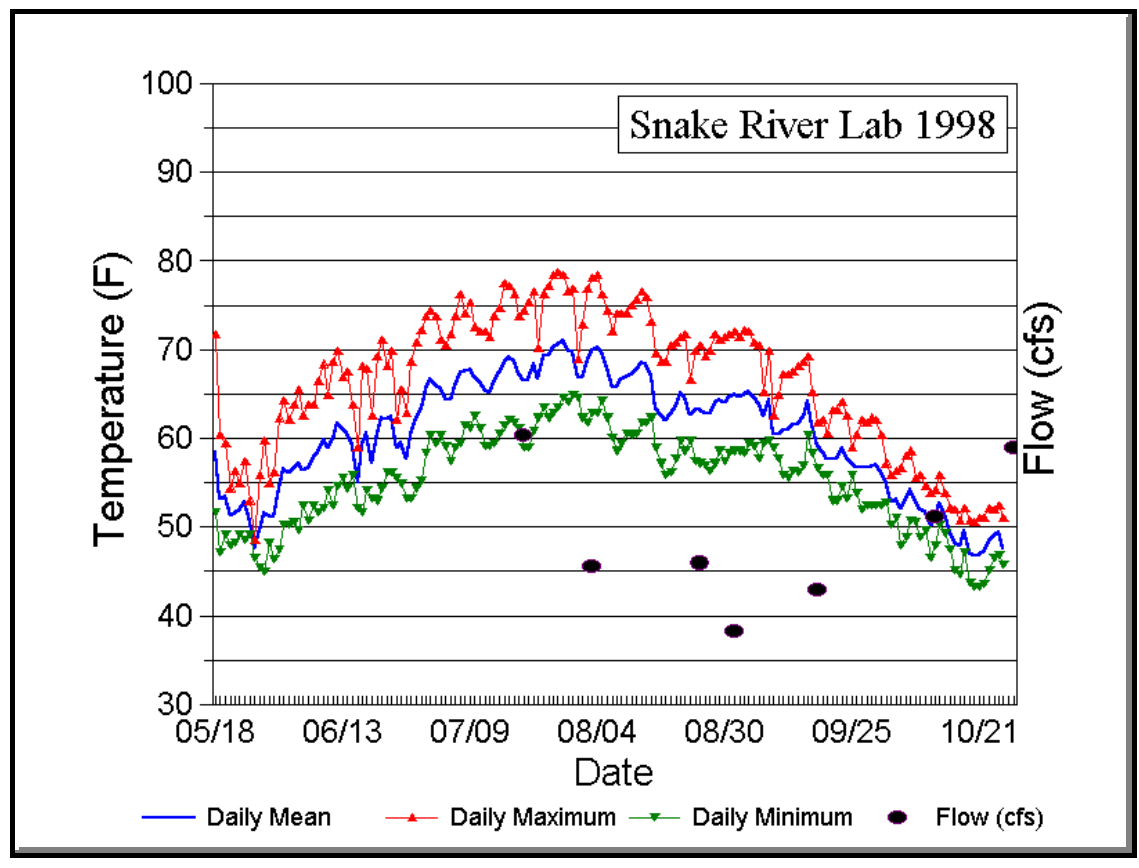

Summary of Daily Temperature Values for Continuous Instream Monitor Placed at Dayton Steelhead Pond Intake, 1998. Manual flow measurement nearby.

\begin{tabular}{|c|c|c|c|c|c|c|c|c|}
\hline Date & $\begin{array}{r}\text { Min } \\
\text { Time } \\
\end{array}$ & $\begin{array}{r}\text { Min } \\
\text { Temp (F) } \\
\end{array}$ & $\begin{array}{r}\text { Max } \\
\text { Time } \\
\end{array}$ & $\begin{array}{r}\text { Max } \\
\text { Temp (F) } \\
\end{array}$ & $\begin{array}{r}\text { Daily } \\
\text { Mean (F) } \\
\end{array}$ & $\begin{array}{l}\text { Daily } \\
\text { Mode }\end{array}$ & $\begin{array}{r}\text { Flow } \\
\text { (cfs) } \\
\end{array}$ & Notes \\
\hline $05 / 18 / 98$ & $23: 15$ & 51.7 & $13: 39$ & 71.7 & 58.4 & 59.0 & & monitor installed \\
\hline 05/19/98 & $06: 27$ & 47.2 & $14: 51$ & 60.4 & 53.2 & 60.0 & & $13: 39 \mathrm{hrs}$ \\
\hline 05/20/98 & $06: 27$ & 49.2 & $14: 51$ & 59.5 & 53.5 & 49.0 & & \\
\hline $05 / 21 / 98$ & $06: 27$ & 48.0 & $14: 51$ & 54.5 & 51.3 & 54.0 & & \\
\hline $05 / 22 / 98$ & $07: 39$ & 48.3 & $17: 15$ & 56.4 & 51.6 & 49.0 & & \\
\hline $05 / 23 / 98$ & $06: 27$ & 49.2 & $17: 15$ & 55.0 & 51.9 & 49.0 & & \\
\hline $05 / 24 / 98$ & $06: 27$ & 48.6 & $16: 03$ & 57.5 & 52.9 & 49.0 & & \\
\hline $05 / 25 / 98$ & $23: 15$ & 49.2 & $00: 27$ & 53.1 & 50.7 & 50.0 & & \\
\hline $05 / 26 / 98$ & $23: 15$ & 46.7 & $00: 27$ & 48.6 & 47.6 & 47.0 & & \\
\hline $05 / 27 / 98$ & $05: 15$ & 45.5 & $17: 15$ & 55.9 & 49.8 & 46.0 & & \\
\hline $05 / 28 / 98$ & $06: 27$ & 45.0 & $17: 15$ & 59.8 & 51.7 & 45.0 & & \\
\hline $05 / 29 / 98$ & $06: 27$ & 48.3 & $17: 15$ & 55.0 & 51.3 & 49.0 & & \\
\hline 05/30/98 & $06: 27$ & 46.4 & $16: 03$ & 56.1 & 51.1 & 47.0 & & \\
\hline $05 / 31 / 98$ & $06: 27$ & 47.5 & $17: 15$ & 62.4 & 54.3 & 62.0 & & \\
\hline 06/01/98 & $05: 15$ & 50.3 & $17: 15$ & 64.4 & 56.5 & 51.0 & & \\
\hline $06 / 02 / 98$ & $06: 27$ & 50.3 & $17: 15$ & 62.1 & 56.1 & 62.0 & & \\
\hline
\end{tabular}


Summary of Daily Temperature Values for Continuous Instream Monitor Placed at Dayton Steelhead Pond Intake, 1998. Manual flow measurement nearby.

\begin{tabular}{|c|c|c|c|c|c|c|c|}
\hline Date & $\begin{array}{l}\text { Min } \\
\text { Time }\end{array}$ & $\begin{array}{r}\text { Min } \\
\text { Temp (F) }\end{array}$ & $\begin{array}{c}\text { Max } \\
\text { Time }\end{array}$ & $\begin{array}{r}\text { Max } \\
\text { Temp (F) }\end{array}$ & $\begin{array}{r}\text { Daily } \\
\text { Mean (F) }\end{array}$ & $\begin{array}{l}\text { Daily } \\
\text { Mode }\end{array}$ & $\begin{array}{r}\text { Flow } \\
\text { (cfs) Notes }\end{array}$ \\
\hline $06 / 03 / 98$ & $06: 27$ & 50.6 & $17: 15$ & 63.8 & 56.8 & 51.0 & \\
\hline $06 / 04 / 98$ & $06: 27$ & 49.7 & $17: 15$ & 65.5 & 57.1 & 50.0 & \\
\hline $06 / 05 / 98$ & $06: 27$ & 52.5 & $16: 03$ & 62.7 & 56.4 & 53.0 & \\
\hline 06/06/98 & $06: 27$ & 50.8 & $17: 15$ & 63.8 & 56.8 & 51.0 & \\
\hline $06 / 07 / 98$ & $06: 27$ & 52.5 & $17: 15$ & 63.8 & 58.0 & 53.0 & \\
\hline 06/08/98 & $06: 27$ & 51.7 & $17: 15$ & 66.4 & 58.5 & 52.0 & \\
\hline 06/09/98 & $06: 27$ & 52.2 & $17: 15$ & 68.4 & 59.8 & 68.0 & \\
\hline $06 / 10 / 98$ & $06: 27$ & 54.2 & $14: 51$ & 65.0 & 58.9 & 54.0 & \\
\hline $06 / 11 / 98$ & $06: 27$ & 52.5 & $17: 15$ & 68.7 & 60.1 & 53.0 & \\
\hline $06 / 12 / 98$ & 07:39 & 54.7 & $17: 15$ & 69.9 & 61.8 & 55.0 & \\
\hline $06 / 13 / 98$ & $06: 27$ & 55.6 & $16: 03$ & 67.0 & 61.1 & 56.0 & \\
\hline $06 / 14 / 98$ & $06: 27$ & 54.5 & $16: 03$ & 67.6 & 60.6 & 54.0 & \\
\hline $06 / 15 / 98$ & $07: 39$ & 55.9 & $16: 03$ & 63.8 & 59.2 & 56.0 & \\
\hline $06 / 16 / 98$ & 07:39 & 52.2 & $18: 27$ & 58.9 & 55.0 & 53.0 & \\
\hline $06 / 17 / 98$ & $06: 27$ & 51.7 & $16: 03$ & 68.2 & 59.4 & 52.0 & \\
\hline $06 / 18 / 98$ & $06: 27$ & 54.2 & $16: 03$ & 67.9 & 60.7 & 54.0 & \\
\hline $06 / 19 / 98$ & $08: 51$ & 53.3 & $18: 27$ & 62.7 & 57.2 & 54.0 & \\
\hline $06 / 20 / 98$ & $06: 27$ & 53.1 & $17: 15$ & 69.3 & 60.6 & 53.0 & \\
\hline $06 / 21 / 98$ & $06: 27$ & 54.5 & $17: 15$ & 71.1 & 62.4 & 71.0 & \\
\hline $06 / 22 / 98$ & $06: 27$ & 56.1 & $14: 51$ & 68.2 & 62.2 & 58.0 & \\
\hline $06 / 23 / 98$ & $06: 27$ & 56.1 & $17: 15$ & 69.9 & 62.5 & 57.0 & \\
\hline $06 / 24 / 98$ & 07:39 & 55.6 & $17: 15$ & 62.1 & 58.9 & 60.0 & \\
\hline $06 / 25 / 98$ & $07: 39$ & 55.0 & $16: 03$ & 65.5 & 59.5 & 55.0 & \\
\hline $06 / 26 / 98$ & $06: 27$ & 53.3 & $17: 15$ & 62.9 & 57.7 & 54.0 & \\
\hline $06 / 27 / 98$ & $06: 27$ & 53.3 & $17: 15$ & 68.7 & 60.5 & 54.0 & \\
\hline $06 / 28 / 98$ & $06: 27$ & 54.5 & $17: 15$ & 70.8 & 62.3 & 55.0 & \\
\hline $06 / 29 / 98$ & 07:39 & 55.3 & $17: 15$ & 72.3 & 63.4 & 55.0 & \\
\hline $06 / 30 / 98$ & 07:39 & 58.4 & $17: 15$ & 73.8 & 65.7 & 58.0 & \\
\hline 07/01/98 & $06: 27$ & 60.4 & $17: 15$ & 74.4 & 66.7 & 61.0 & \\
\hline $07 / 02 / 98$ & 07:39 & 59.5 & $16: 03$ & 73.8 & 66.0 & 60.0 & \\
\hline 07/03/98 & 07:39 & 60.4 & $18: 27$ & 71.1 & 65.6 & 70.0 & \\
\hline $07 / 04 / 98$ & 07:39 & 59.2 & $16: 03$ & 70.5 & 64.5 & 64.0 & \\
\hline $07 / 05 / 98$ & $06: 27$ & 57.5 & $17: 15$ & 71.7 & 64.3 & 58.0 & \\
\hline 07/06/98 & $06: 27$ & 58.9 & $17: 15$ & 73.8 & 65.9 & 59.0 & \\
\hline 07/07/98 & $06: 27$ & 59.5 & $17: 15$ & 76.3 & 67.5 & 60.0 & \\
\hline 07/08/98 & 07:39 & 61.5 & $17: 17$ & 74.1 & 67.6 & 62.0 & \\
\hline 07/09/98 & $07: 41$ & 61.2 & $17: 17$ & 75.4 & 67.8 & 62.0 & \\
\hline 07/10/98 & $06: 29$ & 62.7 & $17: 17$ & 72.6 & 67.0 & 64.0 & \\
\hline $07 / 11 / 98$ & 06:29 & 61.2 & $17: 17$ & 72.0 & 66.4 & 71.0 & \\
\hline
\end{tabular}


Summary of Daily Temperature Values for Continuous Instream Monitor Placed at Dayton Steelhead Pond Intake, 1998. Manual flow measurement nearby.

\begin{tabular}{|c|c|c|c|c|c|c|c|c|}
\hline Date & $\begin{array}{r}\text { Min } \\
\text { Time }\end{array}$ & $\begin{array}{r}\text { Min } \\
\text { Temp (F) }\end{array}$ & $\begin{array}{r}\text { Max } \\
\text { Time }\end{array}$ & $\begin{array}{r}\text { Max } \\
\text { Temp (F) }\end{array}$ & $\begin{array}{r}\text { Daily } \\
\text { Mean (F) }\end{array}$ & $\begin{array}{l}\text { Daily } \\
\text { Mode }\end{array}$ & $\begin{array}{r}\text { Flow } \\
\text { (cfs) }\end{array}$ & Notes \\
\hline $07 / 12 / 98$ & 06:29 & 59.2 & $17: 17$ & 72.0 & 65.4 & 60.0 & & \\
\hline 07/13/98 & 07:41 & 59.2 & $16: 05$ & 71.4 & 65.2 & 71.0 & & \\
\hline $07 / 14 / 98$ & $06: 29$ & 59.5 & $17: 17$ & 73.8 & 66.4 & 60.0 & & \\
\hline $07 / 15 / 98$ & $07: 41$ & 60.6 & $17: 17$ & 74.8 & 67.5 & 62.0 & & \\
\hline 07/16/98 & $06: 29$ & 61.5 & $17: 17$ & 77.6 & 68.7 & 62.0 & & \\
\hline 07/17/98 & 07:41 & 62.1 & $17: 17$ & 77.2 & 69.2 & 63.0 & & \\
\hline $07 / 18 / 98$ & 07:41 & 61.8 & $16: 05$ & 76.3 & 68.7 & 62.0 & & \\
\hline 07/19/98 & $06: 29$ & 61.2 & $16: 05$ & 73.8 & 67.3 & 62.0 & & \\
\hline 07/20/98 & $06: 29$ & 58.9 & $16: 05$ & 74.4 & 66.5 & 74.0 & 60.3 & \\
\hline $07 / 21 / 98$ & $06: 29$ & 58.9 & $17: 17$ & 75.4 & 66.7 & 60.0 & & \\
\hline $07 / 22 / 98$ & $06: 29$ & 60.9 & $16: 05$ & 76.6 & 68.3 & 61.0 & & \\
\hline $07 / 23 / 98$ & $06: 29$ & 62.4 & $16: 05$ & 70.2 & 66.8 & 70.0 & & \\
\hline $07 / 24 / 98$ & $06: 29$ & 63.5 & $17: 17$ & 76.3 & 69.3 & 64.0 & & \\
\hline 07/25/98 & $06: 29$ & 62.4 & $17: 17$ & 77.2 & 69.5 & 77.0 & & \\
\hline $07 / 26 / 98$ & $06: 29$ & 62.9 & $16: 05$ & 78.5 & 70.2 & 64.0 & & \\
\hline 07/27/98 & $06: 29$ & 63.5 & $16: 05$ & 78.8 & 70.6 & 64.0 & & \\
\hline $07 / 28 / 98$ & $06: 29$ & 64.7 & $17: 17$ & 78.5 & 71.1 & 65.0 & & \\
\hline 07/29/98 & $06: 29$ & 64.1 & $16: 05$ & 76.6 & 70.0 & 64.0 & & \\
\hline 07/30/98 & $06: 29$ & 65.0 & $17: 17$ & 76.9 & 69.8 & 66.0 & & \\
\hline $07 / 31 / 98$ & $08: 53$ & 64.7 & $16: 05$ & 69.0 & 66.8 & 65.0 & & \\
\hline 08/01/98 & $06: 29$ & 62.4 & $17: 17$ & 72.9 & 66.8 & 62.0 & & \\
\hline $08 / 02 / 98$ & 07:41 & 61.8 & $16: 05$ & 76.9 & 68.8 & 62.0 & & \\
\hline 08/03/98 & $06: 29$ & 62.9 & $16: 05$ & 78.2 & 70.0 & 64.0 & 45.6 & \\
\hline 08/04/98 & $06: 29$ & 62.9 & $16: 05$ & 78.5 & 70.2 & 63.0 & & \\
\hline 08/05/98 & $06: 29$ & 64.4 & $16: 05$ & 76.3 & 69.7 & 65.0 & & \\
\hline 08/06/98 & $07: 41$ & 62.4 & $17: 17$ & 74.4 & 68.0 & 63.0 & & \\
\hline 08/07/98 & $07: 41$ & 60.1 & $17: 17$ & 72.0 & 65.8 & 72.0 & & \\
\hline 08/08/98 & $06: 29$ & 58.7 & $16: 05$ & 74.1 & 65.9 & 59.0 & & \\
\hline 08/09/98 & 07:41 & 59.5 & $17: 17$ & 74.1 & 66.7 & 60.0 & & \\
\hline 08/10/98 & 07:41 & 60.6 & $17: 17$ & 74.1 & 67.1 & 61.0 & & \\
\hline 08/11/98 & $07: 41$ & 60.4 & $16: 05$ & 75.1 & 67.3 & 61.0 & & \\
\hline $08 / 12 / 98$ & 07:41 & 60.6 & $16: 05$ & 75.7 & 67.8 & 62.0 & & \\
\hline 08/13/98 & $06: 29$ & 61.8 & $16: 05$ & 76.6 & 68.6 & 62.0 & & \\
\hline $08 / 14 / 98$ & 07:41 & 61.8 & $16: 05$ & 76.0 & 68.4 & 63.0 & & \\
\hline $08 / 15 / 98$ & 07:41 & 62.4 & $16: 05$ & 73.2 & 67.1 & 63.0 & & \\
\hline 08/16/98 & $07: 41$ & 58.9 & $16: 05$ & 69.6 & 63.4 & 59.0 & & \\
\hline 08/17/98 & $07: 41$ & 57.3 & $16: 19$ & 68.7 & 62.6 & 58.0 & & \\
\hline 08/18/98 & $07: 55$ & 55.9 & $17: 31$ & 68.7 & 62.0 & 56.0 & & \\
\hline 08/19/98 & $07: 55$ & 56.1 & $16: 19$ & 70.5 & 62.9 & 56.0 & & \\
\hline
\end{tabular}


Summary of Daily Temperature Values for Continuous Instream Monitor Placed at Dayton Steelhead Pond Intake, 1998. Manual flow measurement nearby.

\begin{tabular}{|c|c|c|c|c|c|c|c|c|}
\hline Date & $\begin{array}{c}\text { Min } \\
\text { Time }\end{array}$ & $\begin{array}{r}\text { Min } \\
\text { Temp (F) }\end{array}$ & $\begin{array}{c}\text { Max } \\
\text { Time }\end{array}$ & $\begin{array}{r}\text { Max } \\
\text { Temp (F) }\end{array}$ & $\begin{array}{r}\text { Daily } \\
\text { Mean (F) }\end{array}$ & $\begin{array}{l}\text { Daily } \\
\text { Mode }\end{array}$ & $\begin{array}{r}\text { Flow } \\
\text { (cfs) }\end{array}$ & Notes \\
\hline $08 / 20 / 98$ & $07: 55$ & 57.8 & $16: 19$ & 70.8 & 63.8 & 59.0 & & \\
\hline $08 / 21 / 98$ & $06: 43$ & 59.8 & $16: 19$ & 71.4 & 65.1 & 60.0 & & \\
\hline $08 / 22 / 98$ & $07: 55$ & 58.7 & $16: 19$ & 71.7 & 64.7 & 59.0 & & \\
\hline $08 / 23 / 98$ & $06: 43$ & 59.8 & $16: 19$ & 66.7 & 62.6 & 60.0 & & \\
\hline $08 / 24 / 98$ & $07: 55$ & 57.5 & $16: 19$ & 69.9 & 63.2 & 58.0 & & \\
\hline $08 / 25 / 98$ & $06: 43$ & 57.3 & $16: 19$ & 70.5 & 63.3 & 58.0 & 46.0 & \\
\hline $08 / 26 / 98$ & $07: 55$ & 57.0 & $16: 19$ & 69.3 & 62.7 & 58.0 & & \\
\hline $08 / 27 / 98$ & $07: 55$ & 56.4 & $16: 19$ & 69.9 & 62.7 & 56.0 & & \\
\hline $08 / 28 / 98$ & $07: 55$ & 57.3 & $16: 19$ & 71.7 & 64.1 & 58.0 & & \\
\hline 08/29/98 & $06: 43$ & 58.7 & $16: 19$ & 71.1 & 64.4 & 59.0 & & \\
\hline 08/30/98 & $07: 55$ & 57.5 & $16: 19$ & 71.4 & 64.1 & 58.0 & & \\
\hline $08 / 31 / 98$ & $07: 55$ & 58.4 & $16: 19$ & 71.7 & 64.7 & 59.0 & & \\
\hline 09/01/98 & $07: 55$ & 58.7 & $16: 19$ & 72.0 & 64.9 & 60.0 & 38.3 & \\
\hline 09/02/98 & 07:55 & 58.7 & $16: 19$ & 71.4 & 64.7 & 59.0 & & \\
\hline 09/03/98 & $07: 55$ & 58.4 & $16: 19$ & 72.3 & 65.0 & 59.0 & & \\
\hline 09/04/98 & $07: 55$ & 59.5 & $16: 19$ & 72.0 & 65.3 & 60.0 & & \\
\hline 09/05/98 & $06: 43$ & 59.2 & $16: 19$ & 70.8 & 64.7 & 59.0 & & \\
\hline 09/06/98 & $07: 55$ & 57.8 & $16: 19$ & 70.5 & 63.9 & 58.0 & & \\
\hline 09/07/98 & $06: 43$ & 59.5 & $18: 43$ & 65.3 & 62.6 & 60.0 & & \\
\hline 09/08/98 & $07: 55$ & 59.8 & $16: 19$ & 69.9 & 64.3 & 60.0 & & \\
\hline 09/09/98 & $11: 31$ & 58.9 & $00: 43$ & 62.7 & 60.5 & 60.0 & & \\
\hline 09/10/98 & $07: 55$ & 57.8 & $16: 19$ & 65.0 & 60.5 & 58.0 & & \\
\hline 09/11/98 & $07: 55$ & 55.9 & $16: 19$ & 67.3 & 61.0 & 56.0 & & \\
\hline $09 / 12 / 98$ & $06: 43$ & 55.6 & $16: 19$ & 67.3 & 61.0 & 56.0 & & \\
\hline 09/13/98 & $06: 43$ & 56.4 & $16: 19$ & 67.6 & 61.5 & 57.0 & & \\
\hline 09/14/98 & $07: 55$ & 56.1 & $16: 19$ & 68.2 & 61.7 & 57.0 & & \\
\hline $09 / 15 / 98$ & $06: 43$ & 57.0 & $16: 19$ & 68.7 & 62.5 & 58.0 & & \\
\hline 09/16/98 & $07: 55$ & 60.4 & $15: 07$ & 69.3 & 64.1 & 61.0 & & \\
\hline 09/17/98 & $06: 43$ & 58.4 & $17: 31$ & 65.3 & 61.6 & 60.0 & & \\
\hline 09/18/98 & $06: 43$ & 56.7 & $15: 07$ & 61.8 & 59.2 & 58.0 & 43.0 & \\
\hline 09/19/98 & $07: 55$ & 55.9 & $13: 55$ & 62.1 & 58.5 & 56.0 & & \\
\hline 09/20/98 & $05: 31$ & 55.9 & $16: 19$ & 60.6 & 57.7 & 56.0 & & \\
\hline $09 / 21 / 98$ & $07: 55$ & 53.1 & $17: 31$ & 63.2 & 57.7 & 54.0 & & \\
\hline $09 / 22 / 98$ & $06: 43$ & 53.1 & $17: 31$ & 63.2 & 57.9 & 54.0 & & \\
\hline $09 / 23 / 98$ & $07: 55$ & 54.7 & $16: 19$ & 64.1 & 58.9 & 55.0 & & \\
\hline $09 / 24 / 98$ & $07: 55$ & 53.3 & $15: 07$ & 62.7 & 57.8 & 54.0 & & \\
\hline $09 / 25 / 98$ & $07: 55$ & 55.9 & $15: 07$ & 58.9 & 57.2 & 56.0 & & \\
\hline 09/26/98 & $07: 55$ & 53.9 & $15: 07$ & 60.4 & 56.7 & 56.0 & & \\
\hline 09/27/98 & $07: 55$ & 52.0 & $17: 31$ & 62.1 & 56.7 & 53.0 & & \\
\hline
\end{tabular}


Summary of Daily Temperature Values for Continuous Instream Monitor Placed at Dayton Steelhead Pond Intake, 1998. Manual flow measurement nearby.

\begin{tabular}{|c|c|c|c|c|c|c|c|c|}
\hline Date & $\begin{array}{r}\text { Min } \\
\text { Time } \\
\end{array}$ & $\begin{array}{r}\text { Min } \\
\text { Temp (F) } \\
\end{array}$ & $\begin{array}{r}\text { Max } \\
\text { Time } \\
\end{array}$ & $\begin{array}{r}\text { Max } \\
\text { Temp (F) } \\
\end{array}$ & $\begin{array}{r}\text { Daily } \\
\text { Mean (F) } \\
\end{array}$ & $\begin{array}{l}\text { Daily } \\
\text { Mode }\end{array}$ & $\begin{array}{r}\text { Flow } \\
(\mathrm{cfs})\end{array}$ & Notes \\
\hline $09 / 28 / 98$ & $07: 55$ & 52.5 & $17: 31$ & 61.8 & 56.8 & 53.0 & & \\
\hline $09 / 29 / 98$ & $07: 55$ & 52.5 & $16: 19$ & 62.4 & 57.0 & 53.0 & & \\
\hline $09 / 30 / 98$ & $07: 55$ & 52.5 & $16: 19$ & 62.1 & 57.0 & 53.0 & & \\
\hline $10 / 01 / 98$ & $06: 43$ & 52.5 & $16: 19$ & 60.4 & 56.3 & 53.0 & & \\
\hline $10 / 02 / 98$ & $23: 31$ & 52.8 & $13: 55$ & 57.3 & 55.0 & 54.0 & & \\
\hline $10 / 03 / 98$ & $07: 55$ & 50.3 & $15: 07$ & 55.9 & 52.8 & 51.0 & & \\
\hline $10 / 04 / 98$ & $07: 55$ & 51.1 & $16: 19$ & 56.4 & 53.2 & 51.0 & & \\
\hline $10 / 05 / 98$ & $07: 55$ & 48.0 & $17: 31$ & 56.7 & 52.1 & 49.0 & & \\
\hline $10 / 06 / 98$ & $07: 55$ & 48.9 & $17: 31$ & 58.1 & 53.3 & 49.0 & & \\
\hline $10 / 07 / 98$ & $07: 55$ & 50.8 & $16: 19$ & 58.7 & 54.3 & 51.0 & & \\
\hline $10 / 08 / 98$ & $06: 43$ & 50.6 & $17: 31$ & 55.6 & 52.8 & 51.0 & & \\
\hline $10 / 09 / 98$ & 09:07 & 48.9 & $15: 07$ & 55.9 & 52.0 & 49.0 & & \\
\hline $10 / 10 / 98$ & $23: 31$ & 49.7 & $15: 07$ & 54.7 & 51.7 & 50.0 & & \\
\hline $10 / 11 / 98$ & $06: 43$ & 46.7 & $17: 31$ & 53.9 & 50.1 & 47.0 & & \\
\hline $10 / 12 / 98$ & $07: 55$ & 48.0 & $16: 19$ & 54.2 & 51.2 & 49.0 & 51.2 & \\
\hline $10 / 13 / 98$ & $06: 43$ & 50.3 & $15: 07$ & 55.9 & 52.7 & 51.0 & & \\
\hline $10 / 14 / 98$ & $23: 31$ & 49.4 & $13: 55$ & 53.9 & 51.4 & 50.0 & & \\
\hline $10 / 15 / 98$ & $07: 55$ & 47.5 & $15: 07$ & 52.2 & 49.4 & 47.0 & & \\
\hline $10 / 16 / 98$ & $07: 55$ & 45.3 & $16: 19$ & 52.0 & 48.3 & 47.0 & & \\
\hline $10 / 17 / 98$ & $06: 43$ & 44.7 & $18: 43$ & 50.8 & 47.8 & 45.0 & & \\
\hline $10 / 18 / 98$ & $23: 31$ & 47.2 & $15: 07$ & 52.2 & 49.6 & 49.0 & & \\
\hline $10 / 19 / 98$ & $07: 55$ & 43.9 & $17: 31$ & 50.8 & 47.2 & 45.0 & & \\
\hline $10 / 20 / 98$ & $07: 55$ & 43.3 & $17: 31$ & 50.6 & 46.8 & 44.0 & & \\
\hline $10 / 21 / 98$ & $07: 55$ & 43.3 & $16: 19$ & 51.1 & 47.0 & 44.0 & & \\
\hline $10 / 22 / 98$ & $07: 55$ & 43.6 & $17: 31$ & 51.1 & 47.2 & 44.0 & & \\
\hline $10 / 23 / 98$ & $07: 55$ & 45.3 & $17: 31$ & 52.2 & 48.5 & 46.0 & & \\
\hline $10 / 24 / 98$ & $07: 55$ & 46.7 & $17: 31$ & 52.0 & 49.1 & 47.0 & & \\
\hline $10 / 25 / 98$ & 09:07 & 46.9 & $16: 19$ & 52.5 & 49.5 & 49.0 & & \\
\hline $10 / 26 / 98$ & $07: 55$ & 45.8 & $13: 55$ & 51.1 & 47.5 & 46.0 & & $\begin{array}{l}\text { monitor removed } \\
13: 55 \mathrm{hrs} \text {. }\end{array}$ \\
\hline $10 / 28 / 98$ & & & & & & & 58.9 & \\
\hline
\end{tabular}




\section{Summary of Daily Temperatures and Flows for the Continuous Instream Monitor Placed at Swegle Rd., Walla Walla River, 1998}

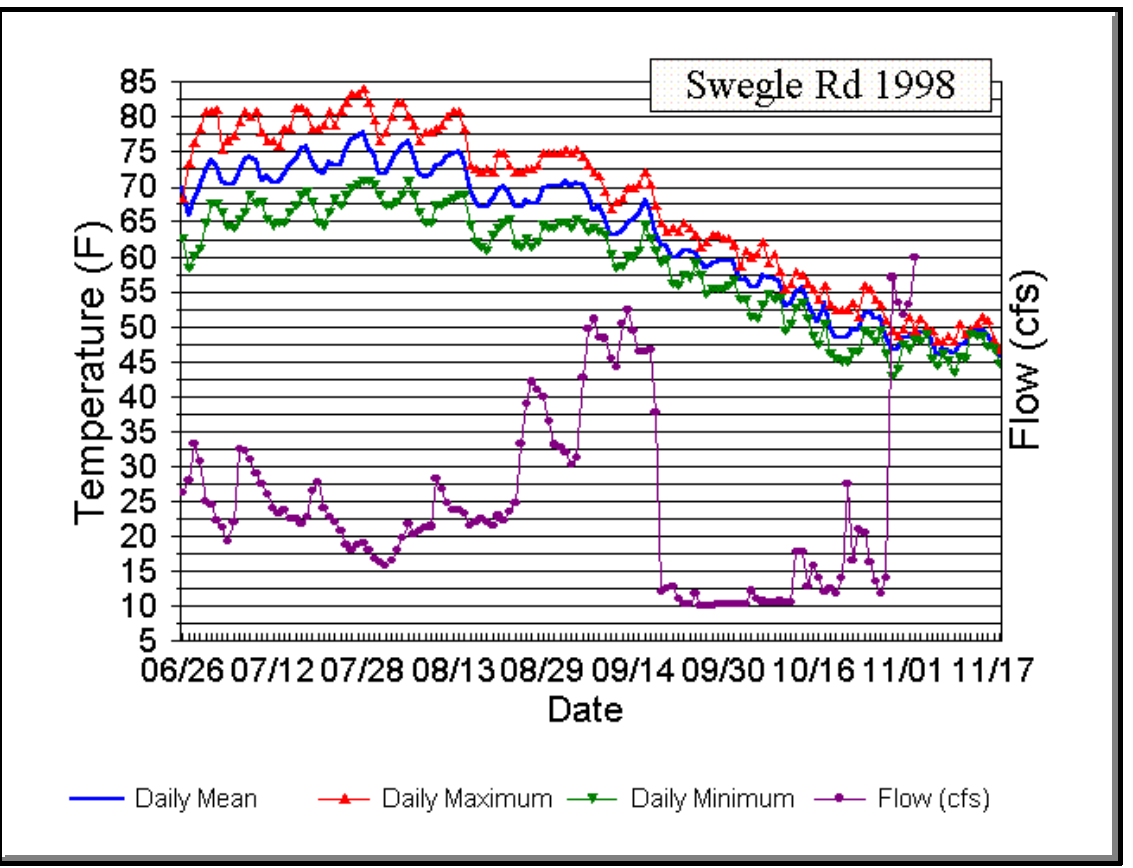

Summary of Daily Temperature Values for Continuous Instream Monitor Placed at Swegle Rd., Walla Walla, 1988. Manual flows at same location.

\begin{tabular}{lrrrrrrl}
\hline & $\begin{array}{r}\text { Min } \\
\text { Time }\end{array}$ & $\begin{array}{r}\text { Min } \\
\text { Temp (F) }\end{array}$ & $\begin{array}{r}\text { Max } \\
\text { Time }\end{array}$ & $\begin{array}{r}\text { Max } \\
\text { Temp (F) }\end{array}$ & $\begin{array}{r}\text { Daily } \\
\text { Temperature } \\
\text { Mean of means }\end{array}$ & $\begin{array}{r}\text { Daily } \\
\text { Mode }\end{array}$ & $\begin{array}{r}\text { Flow } \\
\text { (cfs) }\end{array}$ \\
& & & & & 69.9 & 71.0 & monitor installed \\
\hline $06 / 26 / 98$ & $23: 59$ & 62.7 & $17: 29$ & 68.5 & 65.8 & 73.0 & $13: 59$ hrs. \\
$06 / 27 / 98$ & $07: 29$ & 58.4 & $17: 14$ & 73.3 & 68.2 & 76.0 & \\
$06 / 28 / 98$ & $06: 59$ & 60.1 & $16: 29$ & 76.4 & 69.7 & 78.0 & \\
$06 / 29 / 98$ & $06: 59$ & 61.3 & $16: 14$ & 78.3 & 72.5 & 65.0 & \\
$06 / 30 / 98$ & $07: 29$ & 65.0 & $15: 59$ & 80.8 & 73.7 & 68.0 & \\
$07 / 01 / 98$ & $07: 29$ & 67.6 & $16: 44$ & 80.8 & 73.2 & 68.0 & 3.4 \\
$07 / 02 / 98$ & $06: 44$ & 67.6 & $15: 28$ & 81.1 & 70.9 & 73.0 & \\
$07 / 03 / 98$ & $06: 58$ & 66.5 & $17: 28$ & 75.5 & 70.3 & 65.0 & \\
$07 / 04 / 98$ & $07: 28$ & 64.4 & $16: 43$ & 76.7 & 70.7 & 77.0 & \\
$07 / 05 / 98$ & $07: 13$ & 64.1 & $16: 28$ & 77.3 & 72.1 & 79.0 & \\
$07 / 06 / 98$ & $07: 43$ & 65.3 & $16: 58$ & 79.2 & 73.7 & 67.0 & \\
$07 / 07 / 98$ & $07: 13$ & 66.5 & $16: 58$ & 80.8 & 74.4 & 80.0 & \\
$07 / 08 / 98$ & $07: 28$ & 68.8 & $17: 28$ & 80.2 & 73.9 & 68.0 & WDFW temp. \\
$07 / 09 / 98$ & $07: 28$ & 67.6 & $16: 58$ & 80.8 & 70.8 & & monitor removed. \\
$07 / 10 / 98$ & $08: 00$ & 67.9 & $08: 00$ & 77.7 & 71.6 & &
\end{tabular}


Summary of Daily Temperature Values for Continuous Instream Monitor Placed at Swegle Rd., Walla Walla, 1988. Manual flows at same location.

\begin{tabular}{|c|c|c|c|c|c|c|c|}
\hline Date & $\begin{array}{c}\text { Min } \\
\text { Time }\end{array}$ & $\begin{array}{r}\text { Min } \\
\text { Temp (F) }\end{array}$ & $\begin{array}{r}\text { Max } \\
\text { Time }\end{array}$ & $\begin{array}{r}\text { Max } \\
\text { Temp (F) }\end{array}$ & $\begin{array}{r}\text { Daily } \\
\text { Temperature } \\
\text { Mean of means } \\
\end{array}$ & $\begin{array}{l}\text { Daily } \\
\text { Mode }\end{array}$ & $\begin{array}{rr}\begin{array}{r}\text { Flow } \\
\text { (cfs) }\end{array} & \\
& \text { Notes } \\
\end{array}$ \\
\hline $07 / 12 / 98$ & 08:00 & 64.5 & 08:00 & 76.6 & 70.7 & & \\
\hline 07/13/98 & 08:00 & 65.0 & 08:00 & 76.0 & 70.9 & & \\
\hline $07 / 14 / 98$ & 08:00 & 65.0 & 08:00 & 78.4 & 71.8 & & \\
\hline $07 / 15 / 98$ & 08:00 & 66.4 & 08:00 & 78.4 & 73.0 & & \\
\hline 07/16/98 & 08:00 & 67.4 & 08:00 & 81.5 & 74.1 & & \\
\hline 07/17/98 & 08:00 & 68.9 & 08:00 & 81.5 & 75.6 & & \\
\hline $07 / 18 / 98$ & 08:00 & 69.4 & 08:00 & 80.8 & 75.7 & & \\
\hline 07/19/98 & 08:00 & 67.9 & 08:00 & 78.4 & 73.8 & & \\
\hline 07/20/98 & 08:00 & 65.0 & 08:00 & 78.4 & 72.3 & & \\
\hline $07 / 21 / 98$ & 08:00 & 64.5 & 08:00 & 79.0 & 71.8 & & \\
\hline $07 / 22 / 98$ & 08:00 & 66.4 & 08:00 & 80.8 & 73.6 & & \\
\hline $07 / 23 / 98$ & 08:00 & 68.4 & $12: 00$ & 79.0 & 73.1 & & \\
\hline 07/24/98 & 08:00 & 67.4 & 08:00 & 80.8 & 73.4 & & \\
\hline $07 / 25 / 98$ & 08:00 & 68.9 & 08:00 & 82.1 & 75.7 & & \\
\hline $07 / 26 / 98$ & 08:00 & 70.0 & 08:00 & 83.5 & 76.9 & & \\
\hline $07 / 27 / 98$ & 08:00 & 70.5 & 08:00 & 83.5 & 77.3 & & \\
\hline $07 / 28 / 98$ & 08:00 & 71.0 & 08:00 & 84.1 & 77.8 & & \\
\hline 07/29/98 & 08:00 & 71.0 & $12: 00$ & 82.1 & 75.7 & & \\
\hline 07/30/98 & 08:00 & 70.5 & 08:00 & 79.6 & 74.8 & & \\
\hline 07/31/98 & $12: 00$ & 68.9 & $12: 00$ & 76.6 & 72.2 & & \\
\hline 08/01/98 & 08:00 & 67.4 & 08:00 & 77.7 & 71.9 & & \\
\hline $08 / 02 / 98$ & 08:00 & 67.4 & 08:00 & 80.2 & 73.7 & & \\
\hline 08/03/98 & 08:00 & 67.9 & 08:00 & 82.1 & 74.9 & & \\
\hline $08 / 04 / 98$ & 08:00 & 68.9 & 08:00 & 82.1 & 75.9 & & \\
\hline $08 / 05 / 98$ & 08:00 & 71.0 & 08:00 & 80.2 & 76.5 & & \\
\hline 08/06/98 & 08:00 & 68.9 & 08:00 & 79.0 & 74.5 & & \\
\hline 08/07/98 & 08:00 & 66.4 & 08:00 & 76.6 & 72.2 & & \\
\hline 08/08/98 & 08:00 & 65.0 & 08:00 & 77.7 & 71.4 & & \\
\hline $08 / 09 / 98$ & 08:00 & 65.0 & 08:00 & 77.7 & 71.8 & & \\
\hline 08/10/98 & 08:00 & 67.4 & 08:00 & 78.4 & 73.1 & & \\
\hline $08 / 11 / 98$ & 08:00 & 67.4 & 08:00 & 79.0 & 73.5 & & \\
\hline $08 / 12 / 98$ & 08:00 & 67.9 & 08:00 & 80.2 & 74.2 & & \\
\hline 08/13/98 & 08:00 & 68.4 & 08:00 & 80.8 & 74.9 & & \\
\hline $08 / 14 / 98$ & 08:00 & 68.9 & 08:00 & 80.8 & 75.2 & & \\
\hline $08 / 15 / 98$ & 08:00 & 68.9 & 04:00 & 78.4 & 74.1 & & \\
\hline $08 / 16 / 98$ & 08:00 & 64.5 & 08:00 & 73.2 & 69.6 & & \\
\hline 08/17/98 & 08:00 & 62.2 & 08:00 & 72.6 & 67.8 & & \\
\hline 08/18/98 & 08:00 & 61.4 & 08:00 & 72.1 & 67.1 & & \\
\hline
\end{tabular}


Summary of Daily Temperature Values for Continuous Instream Monitor Placed at Swegle Rd., Walla Walla, 1988. Manual flows at same location.

\begin{tabular}{|c|c|c|c|c|c|c|c|c|}
\hline Date & $\begin{array}{c}\text { Min } \\
\text { Time }\end{array}$ & $\begin{array}{r}\text { Min } \\
\text { Temp (F) }\end{array}$ & $\begin{array}{r}\text { Max } \\
\text { Time }\end{array}$ & $\begin{array}{r}\text { Max } \\
\text { Temp (F) }\end{array}$ & $\begin{array}{r}\text { Daily } \\
\text { Temperature } \\
\text { Mean of means } \\
\end{array}$ & $\begin{array}{l}\text { Daily } \\
\text { Mode }\end{array}$ & $\begin{array}{r}\text { Flow } \\
(\mathbf{c f s})\end{array}$ & Notes \\
\hline 08/19/98 & 08:00 & 60.9 & 08:00 & 72.6 & 67.2 & & & \\
\hline $08 / 20 / 98$ & 08:00 & 63.2 & 08:00 & 72.1 & 68.2 & & & \\
\hline $08 / 21 / 98$ & 08:00 & 64.1 & 08:00 & 74.8 & 69.6 & & & \\
\hline $08 / 22 / 98$ & 08:00 & 65.0 & 08:00 & 74.8 & 70.1 & & & \\
\hline $08 / 23 / 98$ & 08:00 & 65.5 & $12: 00$ & 73.2 & 69.3 & & & \\
\hline $08 / 24 / 98$ & 08:00 & 61.8 & 08:00 & 72.1 & 67.1 & & & \\
\hline $08 / 25 / 98$ & 08:00 & 61.4 & 08:00 & 72.1 & 67.0 & & & \\
\hline $08 / 26 / 98$ & 08:00 & 62.7 & 08:00 & 72.6 & 68.0 & & & \\
\hline $08 / 27 / 98$ & 08:00 & 61.4 & 08:00 & 72.6 & 67.5 & & & \\
\hline $08 / 28 / 98$ & 08:00 & 62.2 & 08:00 & 73.2 & 67.9 & & & \\
\hline $08 / 29 / 98$ & 08:00 & 64.5 & 08:00 & 74.8 & 69.9 & & & \\
\hline 08/30/98 & 08:00 & 64.1 & 08:00 & 74.8 & 70.1 & & & \\
\hline $08 / 31 / 98$ & 08:00 & 64.1 & 08:00 & 74.8 & 70.1 & & & \\
\hline 09/01/98 & 08:00 & 65.0 & 08:00 & 74.8 & 70.2 & & 25.6 & \\
\hline $09 / 02 / 98$ & 08:00 & 65.0 & 08:00 & 75.4 & 70.7 & & & \\
\hline 09/03/98 & 08:00 & 64.1 & 08:00 & 74.8 & 70.2 & & & \\
\hline 09/04/98 & 08:00 & 65.5 & 08:00 & 75.4 & 70.7 & & & \\
\hline $09 / 05 / 98$ & 08:00 & 65.0 & 08:00 & 74.3 & 70.5 & & & \\
\hline 09/06/98 & 08:00 & 63.6 & 08:00 & 73.2 & 69.1 & & & \\
\hline 09/07/98 & $12: 00$ & 64.1 & $12: 00$ & 72.1 & 66.5 & & & \\
\hline 09/08/98 & 08:00 & 63.6 & 08:00 & 71.5 & 67.3 & & & \\
\hline 09/09/98 & $12: 00$ & 63.2 & $12: 00$ & 69.4 & 65.3 & & & \\
\hline $09 / 10 / 98$ & 08:00 & 60.5 & 08:00 & 66.9 & 63.2 & & & \\
\hline $09 / 11 / 98$ & 08:00 & 58.3 & 08:00 & 67.9 & 63.2 & & & \\
\hline $09 / 12 / 98$ & 08:00 & 58.8 & 08:00 & 68.4 & 63.8 & & & \\
\hline $09 / 13 / 98$ & 08:00 & 60.0 & 08:00 & 70.0 & 64.9 & & & \\
\hline $09 / 14 / 98$ & 08:00 & 60.0 & 08:00 & 70.0 & 65.4 & & & \\
\hline $09 / 15 / 98$ & 08:00 & 60.9 & 08:00 & 70.5 & 66.0 & & & \\
\hline $09 / 16 / 98$ & 08:00 & 64.5 & 08:00 & 72.1 & 68.0 & & 37.3 & \\
\hline 09/17/98 & 08:00 & 62.7 & $12: 00$ & 70.5 & 66.7 & & & \\
\hline 09/18/98 & $12: 00$ & 60.9 & $12: 00$ & 67.4 & 63.5 & & & \\
\hline 09/19/98 & 08:00 & 59.2 & 08:00 & 65.0 & 62.0 & & & \\
\hline $09 / 20 / 98$ & 08:00 & 59.6 & $12: 00$ & 63.6 & 61.6 & & & \\
\hline $09 / 21 / 98$ & 08:00 & 56.3 & 08:00 & 64.1 & 60.0 & & & \\
\hline $09 / 22 / 98$ & 08:00 & 55.9 & 08:00 & 63.6 & 60.0 & & & \\
\hline $09 / 23 / 98$ & 08:00 & 57.5 & 08:00 & 65.0 & 61.0 & & & \\
\hline $09 / 24 / 98$ & 08:00 & 57.1 & 08:00 & 64.1 & 61.0 & & & \\
\hline $09 / 25 / 98$ & 08:00 & 59.2 & $12: 00$ & 63.2 & 60.6 & & & \\
\hline
\end{tabular}


Summary of Daily Temperature Values for Continuous Instream Monitor Placed at Swegle Rd., Walla Walla, 1988. Manual flows at same location.

\begin{tabular}{|c|c|c|c|c|c|c|c|c|}
\hline Date & $\begin{array}{c}\text { Min } \\
\text { Time }\end{array}$ & $\begin{array}{r}\text { Min } \\
\text { Temp (F) }\end{array}$ & $\begin{array}{r}\text { Max } \\
\text { Time }\end{array}$ & $\begin{array}{r}\text { Max } \\
\text { Temp (F) }\end{array}$ & $\begin{array}{r}\text { Daily } \\
\text { Temperature } \\
\text { Mean of means } \\
\end{array}$ & $\begin{array}{l}\text { Daily } \\
\text { Mode }\end{array}$ & $\begin{array}{r}\text { Flow } \\
(\text { cfs) }\end{array}$ & Notes \\
\hline $09 / 26 / 98$ & 08:00 & 57.5 & 08:00 & 61.4 & 59.3 & & & \\
\hline 09/27/98 & 08:00 & 54.7 & 08:00 & 62.2 & 58.4 & & & \\
\hline $09 / 28 / 98$ & 08:00 & 55.5 & 08:00 & 63.2 & 59.2 & & & \\
\hline $09 / 29 / 98$ & 08:00 & 55.5 & 08:00 & 63.2 & 59.4 & & & \\
\hline 09/30/98 & 08:00 & 55.5 & 08:00 & 62.7 & 59.3 & & & \\
\hline $10 / 01 / 98$ & 08:00 & 55.9 & 08:00 & 62.7 & 59.4 & & & \\
\hline $10 / 02 / 98$ & 08:00 & 56.7 & $12: 00$ & 61.8 & 59.4 & & & \\
\hline $10 / 03 / 98$ & 08:00 & 53.9 & 08:00 & 58.8 & 56.8 & & & \\
\hline $10 / 04 / 98$ & 08:00 & 53.9 & 04:00 & 60.9 & 57.0 & & & \\
\hline $10 / 05 / 98$ & 08:00 & 51.6 & 08:00 & 60.0 & 55.8 & & & \\
\hline $10 / 06 / 98$ & 08:00 & 51.2 & 08:00 & 60.5 & 55.7 & & & \\
\hline $10 / 07 / 98$ & 08:00 & 53.1 & 08:00 & 62.2 & 57.4 & & & \\
\hline $10 / 08 / 98$ & 08:00 & 54.7 & 08:00 & 59.2 & 57.0 & & & \\
\hline $10 / 09 / 98$ & 08:00 & 53.9 & 08:00 & 60.5 & 56.9 & & & \\
\hline $10 / 10 / 98$ & 08:00 & 54.3 & $12: 00$ & 57.9 & 56.3 & & & \\
\hline $10 / 11 / 98$ & 08:00 & 49.3 & 08:00 & 55.5 & 52.8 & & & \\
\hline $10 / 12 / 98$ & 08:00 & 50.4 & 08:00 & 56.3 & 53.3 & & & \\
\hline $10 / 13 / 98$ & 08:00 & 52.7 & 08:00 & 57.9 & 54.9 & & & \\
\hline $10 / 14 / 98$ & 08:00 & 53.5 & 04:00 & 57.5 & 55.5 & & & \\
\hline $10 / 15 / 98$ & 08:00 & 51.2 & 08:00 & 56.3 & 53.6 & & & \\
\hline $10 / 16 / 98$ & 08:00 & 48.6 & 08:00 & 55.5 & 52.0 & & 8.3 & \\
\hline $10 / 17 / 98$ & 08:00 & 47.5 & 08:00 & 53.9 & 50.7 & & & \\
\hline $10 / 18 / 98$ & $12: 00$ & 50.4 & 08:00 & 55.9 & 53.3 & & & \\
\hline $10 / 19 / 98$ & 08:00 & 46.1 & 08:00 & 53.1 & 50.0 & & & \\
\hline $10 / 20 / 98$ & 08:00 & 45.4 & 08:00 & 52.3 & 48.8 & & & \\
\hline $10 / 21 / 98$ & 08:00 & 45.1 & 08:00 & 52.3 & 48.5 & & & \\
\hline $10 / 22 / 98$ & 08:00 & 45.1 & 08:00 & 52.3 & 48.6 & & & \\
\hline $10 / 23 / 98$ & 08:00 & 46.5 & 08:00 & 53.5 & 49.7 & & & \\
\hline $10 / 24 / 98$ & 08:00 & 46.5 & 08:00 & 51.6 & 49.4 & & & \\
\hline $10 / 25 / 98$ & 08:00 & 49.3 & 08:00 & 55.9 & 52.0 & & & \\
\hline $10 / 26 / 98$ & 08:00 & 49.0 & 08:00 & 55.5 & 52.1 & & 20.4 & \\
\hline $10 / 27 / 98$ & 08:00 & 47.9 & 08:00 & 53.9 & 51.2 & & & \\
\hline $10 / 28 / 98$ & $12: 00$ & 49.3 & $12: 00$ & 53.1 & 51.5 & & & \\
\hline $10 / 29 / 98$ & $12: 00$ & 46.1 & $12: 00$ & 50.8 & 49.0 & & & \\
\hline $10 / 30 / 98$ & $12: 00$ & 43.0 & 08:00 & 49.3 & 46.6 & & & \\
\hline $10 / 31 / 98$ & $12: 00$ & 44.1 & 08:00 & 48.6 & 46.9 & & & \\
\hline $11 / 01 / 98$ & 08:00 & 47.5 & 08:00 & 49.7 & 48.5 & & & \\
\hline $11 / 02 / 98$ & 08:00 & 46.8 & 08:00 & 51.6 & 48.7 & & & \\
\hline
\end{tabular}


Summary of Daily Temperature Values for Continuous Instream Monitor Placed at Swegle Rd., Walla Walla, 1988. Manual flows at same location.

\begin{tabular}{|c|c|c|c|c|c|c|c|c|}
\hline Date & $\begin{array}{l}\text { Min } \\
\text { Time }\end{array}$ & $\begin{array}{r}\text { Min } \\
\text { Temp (F) }\end{array}$ & $\begin{array}{l}\text { Max } \\
\text { Time }\end{array}$ & $\begin{array}{r}\text { Max } \\
\text { Temp (F) }\end{array}$ & $\begin{array}{r}\text { Daily } \\
\text { Temperature } \\
\text { Mean of means } \\
\end{array}$ & $\begin{array}{l}\text { Daily } \\
\text { Mode }\end{array}$ & $\begin{array}{r}\text { Flow } \\
\text { (cfs) }\end{array}$ & Notes \\
\hline $11 / 03 / 98$ & $12: 00$ & 48.2 & $12: 00$ & 49.3 & 49.2 & & & \\
\hline $11 / 04 / 98$ & 08:00 & 47.9 & 08:00 & 51.2 & 49.3 & & & \\
\hline $11 / 05 / 98$ & 08:00 & 49.0 & $12: 00$ & 50.1 & 49.5 & & & \\
\hline $11 / 06 / 98$ & $12: 00$ & 45.4 & $12: 00$ & 49.3 & 47.9 & & & \\
\hline $11 / 07 / 98$ & 08:00 & 44.4 & $12: 00$ & 47.9 & 46.0 & & & \\
\hline $11 / 08 / 98$ & 08:00 & 46.1 & 08:00 & 47.9 & 46.8 & & & \\
\hline $11 / 09 / 98$ & 08:00 & 45.1 & 08:00 & 48.6 & 46.7 & & & \\
\hline $11 / 10 / 98$ & $12: 00$ & 43.4 & 08:00 & 47.9 & 46.2 & & & \\
\hline $11 / 11 / 98$ & 08:00 & 45.8 & 08:00 & 50.4 & 47.4 & & & \\
\hline $11 / 12 / 98$ & 08:00 & 45.4 & 08:00 & 49.0 & 47.3 & & & \\
\hline $11 / 13 / 98$ & 04:00 & 49.0 & 08:00 & 49.7 & 49.3 & & & \\
\hline $11 / 14 / 98$ & 08:00 & 48.6 & 04:00 & 50.4 & 49.5 & & 68.4 & \\
\hline $11 / 15 / 98$ & 08:00 & 48.6 & 08:00 & 51.6 & 49.8 & & & \\
\hline $11 / 16 / 98$ & $12: 00$ & 47.2 & $12: 00$ & 50.8 & 48.9 & & & \\
\hline $11 / 17 / 98$ & 08:00 & 46.8 & $12: 00$ & 48.2 & 47.5 & & & \\
\hline $11 / 18 / 98$ & 08:00 & 44.7 & $12: 00$ & 46.8 & 45.7 & & & $\begin{array}{l}\text { monitor removed } \\
16: 00 \mathrm{hrs}\end{array}$ \\
\hline
\end{tabular}




\section{Summary of Daily Temperature Values for the Continuous Instream Monitor Placed at USFS Boundary, NF Touchet River, 1998}

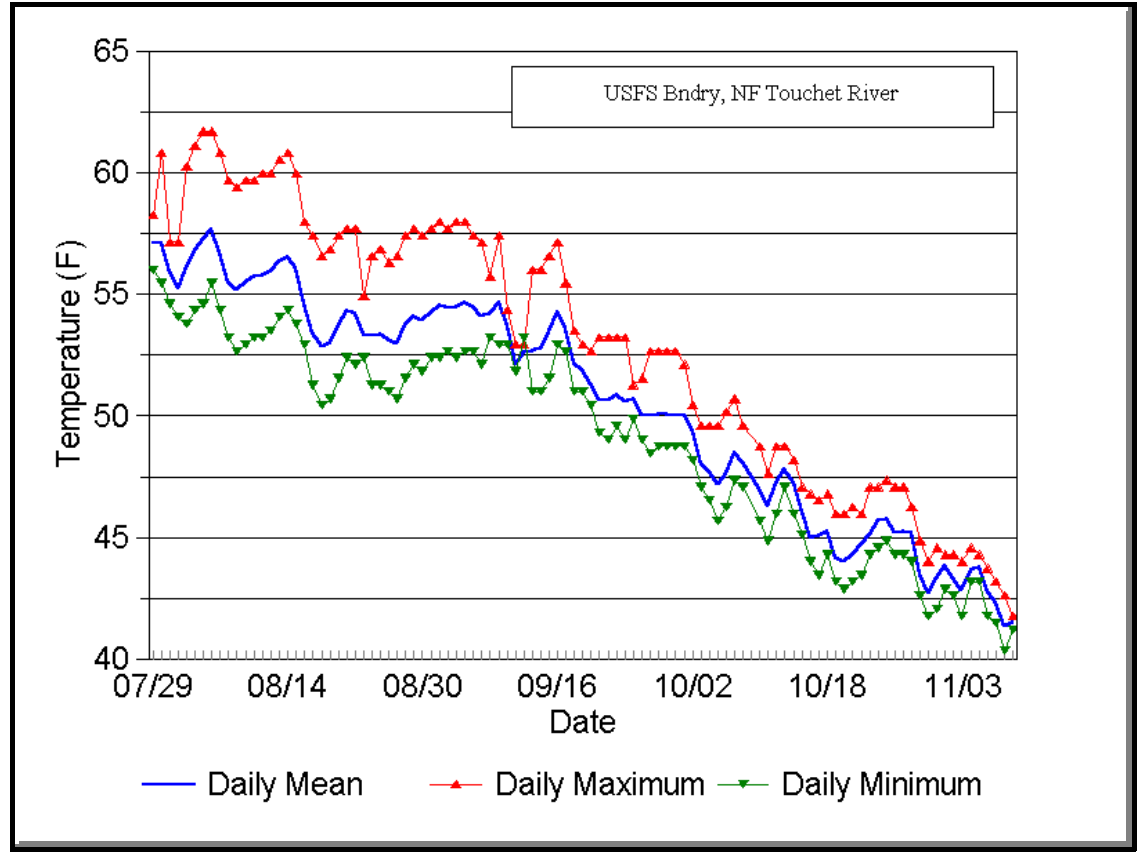

Summary of Daily Temperature Values for the Continuous Instream Monitor Placed at USFS Boundary, NF Touchet River, 1998.

\begin{tabular}{lrrrrrrl}
\hline Date & $\begin{array}{r}\text { Min } \\
\text { Time }\end{array}$ & $\begin{array}{r}\text { Min } \\
\text { Temp (F) }\end{array}$ & $\begin{array}{r}\text { Max } \\
\text { Time }\end{array}$ & $\begin{array}{r}\text { Max } \\
\text { Temp (F) }\end{array}$ & $\begin{array}{r}\text { Daily } \\
\text { Mean (F) }\end{array}$ & $\begin{array}{r}\text { Daily } \\
\text { Mode }\end{array}$ & Notes \\
\hline $07 / 29 / 98$ & $23: 56$ & 56.0 & $15: 26$ & 58.3 & 57.1 & 57.0 & monitor installed 15:26 hrs. \\
$07 / 30 / 98$ & $05: 26$ & 55.5 & $14: 26$ & 60.8 & 57.1 & 57.0 & \\
$07 / 31 / 98$ & $23: 26$ & 54.6 & $11: 56$ & 57.1 & 55.9 & 55.0 & \\
$08 / 01 / 98$ & $06: 26$ & 54.1 & $14: 56$ & 57.1 & 55.2 & 55.0 & \\
$08 / 02 / 98$ & $05: 56$ & 53.8 & $14: 26$ & 60.3 & 56.2 & 54.0 & \\
$08 / 03 / 98$ & $06: 26$ & 54.4 & $14: 26$ & 61.1 & 56.8 & 55.0 & \\
$08 / 04 / 98$ & $07: 26$ & 54.6 & $14: 56$ & 61.7 & 57.3 & 55.0 & \\
$08 / 05 / 98$ & $04: 56$ & 55.5 & $13: 56$ & 61.7 & 57.7 & 56.0 & \\
$08 / 06 / 98$ & $08: 26$ & 54.4 & $14: 26$ & 60.8 & 56.7 & 55.0 & \\
$08 / 07 / 98$ & $06: 56$ & 53.2 & $14: 26$ & 59.7 & 55.5 & 54.0 & \\
$08 / 08 / 98$ & $06: 56$ & 52.7 & $14: 26$ & 59.4 & 55.2 & 53.0 & \\
$08 / 09 / 98$ & $07: 26$ & 53.0 & $14: 56$ & 59.7 & 55.5 & 53.0 & \\
$08 / 10 / 98$ & $06: 56$ & 53.2 & $15: 26$ & 59.7 & 55.7 & 54.0 & \\
$08 / 11 / 98$ & $07: 56$ & 53.2 & $14: 56$ & 60.0 & 55.8 & 54.0 & \\
$08 / 12 / 98$ & $07: 26$ & 53.5 & $13: 59$ & 60.0 & 56.0 & 54.0 & \\
$08 / 13 / 98$ & $06: 29$ & 54.1 & $14: 59$ & 60.5 & 56.4 & 54.0 &
\end{tabular}


Summary of Daily Temperature Values for the Continuous Instream Monitor Placed at USFS Boundary, NF Touchet River, 1998.

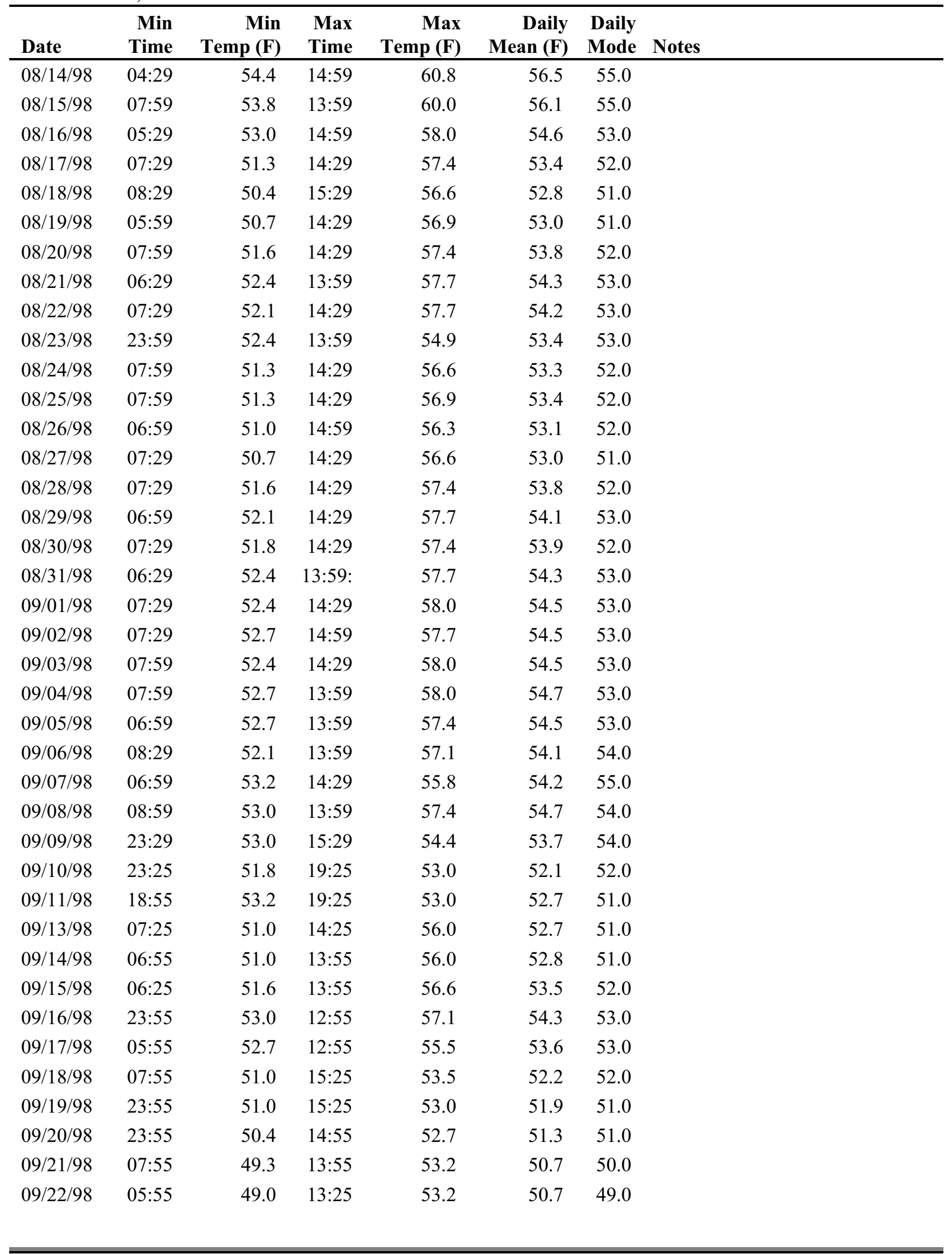


Summary of Daily Temperature Values for the Continuous Instream Monitor Placed at USFS Boundary, NF Touchet River, 1998.

\begin{tabular}{|c|c|c|c|c|c|c|c|}
\hline Date & $\begin{array}{r}\text { Min } \\
\text { Time }\end{array}$ & $\begin{array}{r}\text { Min } \\
\text { Temp (F) }\end{array}$ & $\begin{array}{r}\text { Max } \\
\text { Time }\end{array}$ & $\begin{array}{r}\text { Max } \\
\text { Temp (F) }\end{array}$ & $\begin{array}{r}\text { Daily } \\
\text { Mean (F) }\end{array}$ & $\begin{array}{l}\text { Daily } \\
\text { Mode }\end{array}$ & Notes \\
\hline $09 / 23 / 98$ & $08: 55$ & 49.6 & $14: 55$ & 53.2 & 50.9 & 50.0 & \\
\hline $09 / 24 / 98$ & $07: 25$ & 49.0 & $13: 55$ & 53.2 & 50.6 & 49.0 & \\
\hline $09 / 25 / 98$ & $23: 55$ & 49.9 & $15: 25$ & 51.3 & 50.7 & 51.0 & \\
\hline $09 / 26 / 98$ & $05: 55$ & 49.0 & $15: 55$ & 51.6 & 50.0 & 50.0 & \\
\hline 09/27/98 & $07: 25$ & 48.5 & $14: 25$ & 52.7 & 50.0 & 49.0 & \\
\hline 09/28/98 & $05: 25$ & 48.8 & $14: 25$ & 52.7 & 50.1 & 49.0 & \\
\hline 09/29/98 & $06: 25$ & 48.8 & $13: 55$ & 52.7 & 50.1 & 49.0 & \\
\hline 09/30/98 & $06: 55$ & 48.8 & $13: 25$ & 52.7 & 50.0 & 49.0 & \\
\hline $10 / 01 / 98$ & $05: 55$ & 48.8 & $13: 55$ & 52.1 & 50.0 & 49.0 & \\
\hline $10 / 02 / 98$ & $23: 25$ & 48.2 & $14: 55$ & 50.4 & 49.4 & 50.0 & \\
\hline $10 / 03 / 98$ & $06: 55$ & 47.1 & $13: 55$ & 49.6 & 48.1 & 48.0 & \\
\hline $10 / 04 / 98$ & $23: 25$ & 46.5 & $14: 25$ & 49.6 & 47.7 & 47.0 & \\
\hline $10 / 05 / 98$ & $06: 55$ & 45.7 & $13: 55$ & 49.6 & 47.2 & 46.0 & \\
\hline $10 / 06 / 98$ & $07: 55$ & 46.3 & $13: 25$ & 50.2 & 47.7 & 47.0 & \\
\hline $10 / 07 / 98$ & $02: 25$ & 47.4 & $13: 55$ & 50.7 & 48.5 & 47.0 & \\
\hline $10 / 08 / 98$ & $23: 55$ & 47.1 & $14: 25$ & 49.6 & 48.1 & 48.0 & \\
\hline $10 / 09 / 98$ & & & & & & & no data \\
\hline $10 / 10 / 98$ & $23: 25$ & 45.7 & $14: 25$ & 48.8 & 47.0 & 47.0 & \\
\hline $10 / 11 / 98$ & $08: 55$ & 44.9 & $15: 25$ & 47.7 & 46.3 & 45.0 & \\
\hline $10 / 12 / 98$ & $05: 55$ & 46.0 & $15: 55$ & 48.8 & 47.2 & 48.0 & \\
\hline $10 / 13 / 98$ & $05: 55$ & 47.1 & $14: 25$ & 48.8 & 47.8 & 48.0 & \\
\hline $10 / 14 / 98$ & $22: 55$ & 46.0 & $14: 25$ & 48.2 & 47.3 & 47.0 & \\
\hline $10 / 15 / 98$ & $23: 25$ & 45.1 & $14: 55$ & 47.1 & 46.1 & 46.0 & \\
\hline $10 / 16 / 98$ & $08: 55$ & 44.0 & $13: 25$ & 46.8 & 45.0 & 44.0 & \\
\hline $10 / 17 / 98$ & $05: 25$ & 43.5 & $15: 55$ & 46.5 & 45.1 & 46.0 & \\
\hline $10 / 18 / 98$ & $09: 25$ & 44.3 & $13: 55$ & 46.8 & 45.3 & 45.0 & \\
\hline $10 / 19 / 98$ & $07: 25$ & 43.2 & $14: 25$ & 46.0 & 44.2 & 44.0 & \\
\hline $10 / 20 / 98$ & $08: 25$ & 42.9 & $14: 25$ & 46.0 & 44.0 & 43.0 & \\
\hline $10 / 21 / 98$ & $07: 25$ & 43.2 & $13: 25$ & 46.3 & 44.3 & 43.0 & \\
\hline $10 / 22 / 98$ & $08: 25$ & 43.5 & $16: 14$ & 46.0 & 44.7 & 44.0 & \\
\hline $10 / 23 / 98$ & $05: 44$ & 44.3 & $13: 44$ & 47.1 & 45.2 & 45.0 & \\
\hline $10 / 24 / 98$ & $05: 44$ & 44.6 & $13: 44$ & 47.1 & 45.7 & 45.0 & \\
\hline $10 / 25 / 98$ & $08: 14$ & 44.9 & $13: 44$ & 47.4 & 45.8 & 45.0 & \\
\hline $10 / 26 / 98$ & $07: 14$ & 44.3 & $13: 14$ & 47.1 & 45.2 & 45.0 & \\
\hline $10 / 27 / 98$ & $06: 44$ & 44.3 & $13: 44$ & 47.1 & 45.3 & 45.0 & \\
\hline $10 / 28 / 98$ & $22: 44$ & 44.0 & $13: 14$ & 46.3 & 45.2 & 45.0 & \\
\hline $10 / 29 / 98$ & $22: 14$ & 42.6 & $14: 14$ & 44.9 & 43.5 & 43.0 & \\
\hline $10 / 30 / 98$ & $06: 44$ & 41.8 & $15: 14$ & 44.0 & 42.7 & 42.0 & \\
\hline $10 / 31 / 98$ & $07: 44$ & 42.1 & $15: 44$ & 44.6 & 43.4 & 44.0 & \\
\hline
\end{tabular}


Summary of Daily Temperature Values for the Continuous Instream Monitor Placed at USFS Boundary, NF Touchet River, 1998.

\begin{tabular}{lrrrrrrr}
\hline Date & $\begin{array}{r}\text { Min } \\
\text { Time }\end{array}$ & $\begin{array}{r}\text { Min } \\
\text { Temp (F) }\end{array}$ & $\begin{array}{r}\text { Max } \\
\text { Time }\end{array}$ & $\begin{array}{r}\text { Max } \\
\text { Temp (F) }\end{array}$ & $\begin{array}{r}\text { Daily } \\
\text { Mean }(\mathbf{F})\end{array}$ & $\begin{array}{c}\text { Daily } \\
\text { Mode }\end{array}$ Notes \\
\hline $11 / 01 / 98$ & $22: 44$ & 42.9 & $15: 44$ & 44.3 & 43.8 & 44.0 & \\
$11 / 02 / 98$ & $22: 44$ & 42.6 & $15: 44$ & 44.3 & 43.4 & 43.0 & \\
$11 / 03 / 98$ & $08: 44$ & 41.8 & $13: 14$ & 44.0 & 42.8 & 42.0 & \\
$11 / 04 / 98$ & $05: 44$ & 43.2 & $16: 14$ & 44.6 & 43.7 & 44.0 & \\
$11 / 05 / 98$ & $23: 44$ & 43.2 & $13: 44$ & 44.3 & 43.8 & 44.0 & \\
$11 / 06 / 98$ & $23: 44$ & 41.8 & $14: 14$ & 43.8 & 42.8 & 43.0 & \\
$11 / 07 / 98$ & $07: 14$ & 41.5 & $15: 44$ & 43.2 & 42.3 & 42.0 & \\
$11 / 08 / 98$ & $06: 44$ & 40.4 & $01: 14$ & 42.6 & 41.4 & 42.0 & \\
$11 / 09 / 98$ & $07: 14$ & 41.2 & $10: 14$ & 41.8 & 41.5 & $42.0 \quad$ monitor removed 11:25 hrs. \\
\hline
\end{tabular}




\section{Summary of Daily Temperature Values and Flows for the Continuous Instream Monitor Placed at Lower Yellowhawk Creek, 1998}

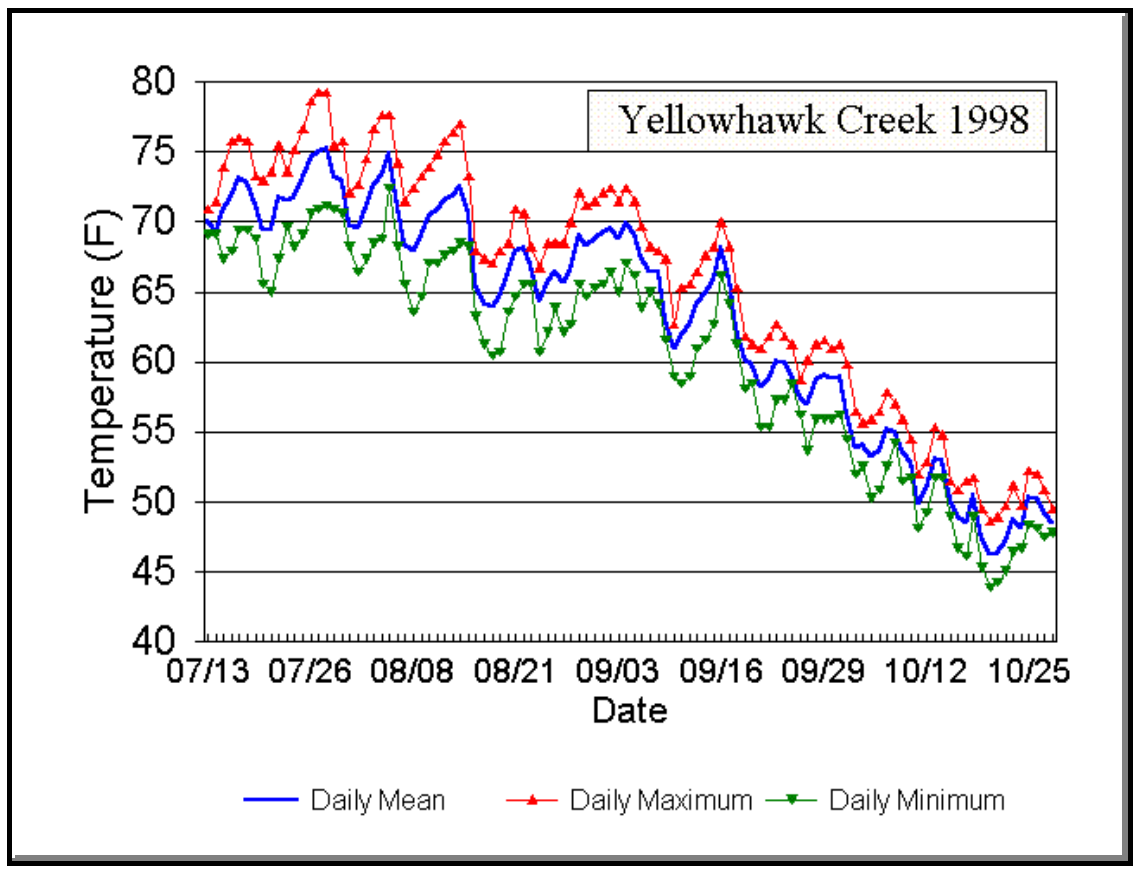

Summary of Daily Temperature Values and Flows for the Continuous Instream Monitor at Lower Yellowhawk Creek, 1998.

\begin{tabular}{lrrrrrrl}
\hline Date & $\begin{array}{r}\text { Min } \\
\text { Time }\end{array}$ & $\begin{array}{r}\text { Min } \\
\text { Temp }(\mathbf{F})\end{array}$ & $\begin{array}{r}\text { Max } \\
\text { Time }\end{array}$ & $\begin{array}{r}\text { Max } \\
\text { Temp }(\mathbf{F})\end{array}$ & $\begin{array}{r}\text { Daily } \\
\text { Mean }\end{array}$ & $\begin{array}{c}\text { Daily } \\
\text { Mode }\end{array}$ & Notes \\
\hline $07 / 13 / 98^{*}$ & $03: 28$ & 69.11 & $14: 58$ & 70.9 & 70.1 & 70.0 & monitor installed 14:58 hrs. \\
$07 / 14 / 98$ & $12: 28$ & 69.11 & $23: 58$ & 71.5 & 69.4 & 66.0 & \\
$07 / 15 / 98$ & $08: 28$ & 67.36 & $17: 58$ & 73.9 & 70.9 & 74.0 & \\
$07 / 16 / 98$ & $06: 58$ & 67.94 & $19: 28$ & 75.8 & 72.0 & 75.0 & \\
$07 / 17 / 98$ & $06: 28$ & 69.41 & $19: 28$ & 76.1 & 73.1 & 76.0 & \\
$07 / 18 / 98$ & $07: 58$ & 69.41 & $16: 28$ & 75.8 & 72.8 & 75.0 & \\
$07 / 19 / 98$ & $06: 28$ & 68.81 & $18: 58$ & 73.3 & 71.2 & 73.0 & \\
$07 / 20 / 98$ & $07: 58$ & 65.6 & $17: 26$ & 73.0 & 69.5 & 66.0 & \\
$07 / 21 / 98$ & $06: 56$ & 65.02 & $18: 26$ & 73.6 & 69.6 & 73.0 & \\
$07 / 22 / 98$ & $07: 58$ & 67.36 & $19: 56$ & 75.5 & 71.8 & 75.0 & \\
$07 / 23 / 98$ & $06: 56$ & 69.7 & $00: 26$ & 73.6 & 71.5 & 72.0 & \\
$07 / 24 / 98$ & $07: 56$ & 68.23 & $17: 56$ & 75.2 & 71.9 & 75.0 & \\
$07 / 25 / 98$ & $07: 26$ & 69.11 & $16: 56$ & 76.7 & 73.1 & 76.0 & \\
$07 / 26 / 98$ & $07: 56$ & 70.61 & $17: 26$ & 78.6 & 74.7 & 71.0 & \\
$07 / 27 / 98$ & $06: 56$ & 70.91 & $16: 26$ & 79.2 & 75.1 & 79.0 & \\
$07 / 28 / 98$ & $07: 26$ & 71.21 & $17: 26$ & 79.2 & 75.3 & 72.0 & \\
$07 / 29 / 98$ & $08: 26$ & 70.91 & $16: 26$ & 75.5 & 73.3 & 75.0 &
\end{tabular}


Summary of Daily Temperature Values and Flows for the Continuous Instream Monitor at Lower Yellowhawk Creek, 1998.

\begin{tabular}{|c|c|c|c|c|c|c|}
\hline Date & $\begin{array}{r}\text { Min } \\
\text { Time }\end{array}$ & $\begin{array}{r}\text { Min } \\
\text { Temp (F) } \\
\end{array}$ & $\begin{array}{r}\text { Max } \\
\text { Time } \\
\end{array}$ & $\begin{array}{r}\text { Max } \\
\text { Temp (F) } \\
\end{array}$ & $\begin{array}{r}\text { Daily } \\
\text { Mean }\end{array}$ & $\begin{array}{l}\text { Daily } \\
\text { Mode Notes }\end{array}$ \\
\hline $07 / 30 / 98$ & $07: 56$ & 70.61 & $15: 26$ & 75.8 & 73.0 & 72.0 \\
\hline 07/31/98 & $11: 56$ & 68.23 & $00: 26$ & 72.1 & 69.8 & 69.0 \\
\hline 08/01/98 & 09:26 & 66.48 & $16: 56$ & 72.7 & 69.5 & 72.0 \\
\hline 08/02/98 & $07: 56$ & 67.36 & $17: 26$ & 74.5 & 71.2 & 74.0 \\
\hline 08/03/98 & $07: 26$ & 68.52 & $16: 26$ & 76.7 & 72.7 & 69.0 \\
\hline 08/04/98 & $07: 26$ & 68.81 & $17: 56$ & 77.7 & 73.5 & 69.0 \\
\hline 08/05/98 & $07: 26$ & 72.41 & $16: 26$ & 77.7 & 74.9 & 75.0 \\
\hline 08/06/98 & 08:56 & 68.23 & $16: 56$ & 74.2 & 71.0 & 72.0 \\
\hline 08/07/98 & $07: 56$ & 65.6 & $16: 26$ & 71.5 & 68.4 & 66.0 \\
\hline 08/08/98 & $07: 26$ & 63.57 & $18: 26$ & 72.4 & 68.0 & 64.0 \\
\hline 08/09/98 & $06: 56$ & 64.73 & $17: 26$ & 73.3 & 69.2 & 72.0 \\
\hline 08/10/98 & $07: 56$ & 67.07 & $17: 26$ & 73.9 & 70.4 & 67.0 \\
\hline 08/11/98 & $06: 56$ & 67.07 & $16: 26$ & 74.8 & 70.9 & 69.0 \\
\hline $08 / 12 / 98$ & $06: 56$ & 67.65 & $16: 56$ & 75.8 & 71.5 & 75.0 \\
\hline 08/13/98 & $07: 26$ & 67.94 & $16: 56$ & 76.4 & 72.0 & 76.0 \\
\hline 08/14/98 & $07: 26$ & 68.52 & $16: 56$ & 77.0 & 72.6 & 69.0 \\
\hline $08 / 15 / 98$ & $07: 56$ & 68.23 & $15: 26$ & 73.3 & 70.7 & 69.0 \\
\hline 08/16/98 & $08: 26$ & 63.28 & $00: 26$ & 67.9 & 65.6 & 67.0 \\
\hline 08/17/98 & $07: 26$ & 61.27 & $17: 58$ & 67.4 & 64.2 & 62.0 \\
\hline 08/18/98 & $07: 28$ & 60.42 & $17: 58$ & 67.1 & 63.9 & 62.0 \\
\hline 08/19/98 & 07:58 & 60.7 & $17: 58$ & 67.9 & 64.7 & 68.0 \\
\hline 08/20/98 & $06: 58$ & 63.57 & $15: 58$ & 68.5 & 66.4 & 68.0 \\
\hline $08 / 21 / 98$ & $07: 28$ & 64.73 & $15: 58$ & 70.9 & 68.0 & 66.0 \\
\hline $08 / 22 / 98$ & 08:58 & 65.6 & $16: 58$ & 70.6 & 68.2 & 66.0 \\
\hline $08 / 23 / 98$ & 08:58 & 65.6 & $00: 58$ & 68.2 & 67.0 & 66.0 \\
\hline $08 / 24 / 98$ & $08: 28$ & 60.7 & $19: 58$ & 66.8 & 64.3 & 66.0 \\
\hline $08 / 25 / 98$ & $07: 58$ & 62.13 & $19: 58$ & 68.5 & 65.8 & 68.0 \\
\hline $08 / 26 / 98$ & $07: 58$ & 63.86 & $17: 28$ & 68.5 & 66.4 & 67.0 \\
\hline $08 / 27 / 98$ & $07: 28$ & 62.13 & $19: 28$ & 68.5 & 65.8 & 68.0 \\
\hline $08 / 28 / 98$ & 08:28 & 62.71 & $19: 28$ & 70.0 & 66.7 & 70.0 \\
\hline 08/29/98 & $07: 58$ & 65.6 & $16: 58$ & 72.1 & 69.0 & 69.0 \\
\hline 08/30/98 & $07: 58$ & 64.73 & $16: 28$ & 71.2 & 68.4 & 71.0 \\
\hline $08 / 31 / 98$ & $07: 28$ & 65.31 & $18: 28$ & 71.5 & 68.8 & 71.0 \\
\hline 09/01/98 & $07: 28$ & 65.6 & $17: 28$ & 72.1 & 69.3 & 72.0 \\
\hline $09 / 02 / 98$ & $07: 58$ & 66.48 & $16: 58$ & 72.4 & 69.6 & 72.0 \\
\hline 09/03/98 & $08: 28$ & 65.02 & $17: 58$ & 71.5 & 68.8 & 71.0 \\
\hline 09/04/98 & $07: 28$ & 67.07 & $16: 28$ & 72.4 & 69.9 & 72.0 \\
\hline $09 / 05 / 98$ & 08:28 & 66.19 & $17: 58$ & 71.5 & 69.2 & 70.0 \\
\hline 09/06/98 & $07: 28$ & 63.86 & $18: 28$ & 69.7 & 67.4 & 69.0 \\
\hline
\end{tabular}


Summary of Daily Temperature Values and Flows for the Continuous Instream Monitor at Lower Yellowhawk Creek, 1998.

\begin{tabular}{|c|c|c|c|c|c|c|}
\hline Date & $\begin{array}{r}\text { Min } \\
\text { Time } \\
\end{array}$ & $\begin{array}{r}\text { Min } \\
\text { Temp (F) } \\
\end{array}$ & $\begin{array}{r}\text { Max } \\
\text { Time } \\
\end{array}$ & $\begin{array}{r}\text { Max } \\
\text { Temp (F) } \\
\end{array}$ & $\begin{array}{l}\text { Daily } \\
\text { Mean }\end{array}$ & $\begin{array}{l}\text { Daily } \\
\text { Mode Notes }\end{array}$ \\
\hline 09/07/98 & $07: 28$ & 65.02 & $00: 28$ & 68.2 & 66.4 & 67.0 \\
\hline 09/08/98 & 08:58 & 64.15 & $22: 28$ & 67.9 & 66.5 & 67.0 \\
\hline 09/09/98 & $10: 28$ & 61.56 & $00: 28$ & 67.4 & 62.9 & 62.0 \\
\hline 09/10/98 & 09:58 & 58.99 & $22: 28$ & 62.7 & 61.0 & 62.0 \\
\hline 09/11/98 & $07: 28$ & 58.42 & $21: 28$ & 65.3 & 61.9 & 65.0 \\
\hline 09/12/98 & $07: 28$ & 58.99 & $20: 58$ & 65.6 & 62.6 & 65.0 \\
\hline $09 / 13 / 98$ & $07: 58$ & 60.99 & $19: 58$ & 66.5 & 64.2 & 66.0 \\
\hline $09 / 14 / 98$ & $08: 28$ & 61.56 & $20: 58$ & 67.7 & 65.0 & 67.0 \\
\hline 09/15/98 & $07: 28$ & 62.71 & $22: 28$ & 68.2 & 65.9 & 68.0 \\
\hline 09/16/98 & $08: 28$ & 66.19 & $15: 58$ & 70.0 & 68.2 & 69.0 \\
\hline 09/17/98 & $07: 58$ & 64.15 & $00: 28$ & 68.2 & 66.0 & 66.0 \\
\hline 09/18/98 & 09:58 & 61.27 & $00: 28$ & 65.3 & 62.3 & 62.0 \\
\hline 09/19/98 & 08:58 & 58.14 & $21: 58$ & 61.9 & 60.3 & 62.0 \\
\hline 09/20/98 & $08: 58$ & 58.42 & $17: 58$ & 61.3 & 59.9 & 60.0 \\
\hline $09 / 21 / 98$ & $07: 58$ & 55.36 & $21: 58$ & 61.0 & 58.3 & 61.0 \\
\hline $09 / 22 / 98$ & $07: 58$ & 55.36 & $21: 28$ & 61.9 & 58.8 & 56.0 \\
\hline $09 / 23 / 98$ & 08:58 & 57.3 & $20: 58$ & 62.7 & 60.1 & 62.0 \\
\hline $09 / 24 / 98$ & $07: 58$ & 57.3 & $21: 28$ & 61.9 & 60.0 & 62.0 \\
\hline $09 / 25 / 98$ & 09:28 & 58.42 & $00: 28$ & 61.3 & 59.1 & 59.0 \\
\hline $09 / 26 / 98$ & 08:58 & 56.19 & $18: 28$ & 58.7 & 57.5 & 58.0 \\
\hline 09/27/98 & $07: 58$ & 53.68 & $21: 58$ & 60.1 & 57.0 & 60.0 \\
\hline 09/28/98 & $08: 28$ & 55.91 & $21: 58$ & 61.3 & 58.7 & 61.0 \\
\hline $09 / 29 / 98$ & $08: 28$ & 55.91 & $21: 17$ & 61.6 & 59.1 & 61.0 \\
\hline 09/30/98 & $07: 47$ & 55.91 & $23: 17$ & 61.0 & 58.8 & 61.0 \\
\hline $10 / 01 / 98$ & 08:47 & 56.19 & $21: 47$ & 61.3 & 58.9 & 60.0 \\
\hline $10 / 02 / 98$ & 09:47 & 54.52 & $00: 17$ & 59.9 & 56.3 & 56.0 \\
\hline $10 / 03 / 98$ & 08:47 & 52 & $00: 17$ & 56.5 & 53.8 & 55.0 \\
\hline $10 / 04 / 98$ & 09:47 & 52.56 & $18: 47$ & 55.6 & 54.2 & 53.0 \\
\hline $10 / 05 / 98$ & $07: 47$ & 50.33 & $20: 17$ & 55.9 & 53.2 & 51.0 \\
\hline $10 / 06 / 98$ & 08:47 & 50.89 & $19: 47$ & 56.5 & 53.7 & 56.0 \\
\hline $10 / 07 / 98$ & $07: 47$ & 52.56 & $20: 17$ & 57.9 & 55.2 & 53.0 \\
\hline $10 / 08 / 98$ & $23: 47$ & 54.24 & $00: 17$ & 57.0 & 55.0 & 55.0 \\
\hline $10 / 09 / 98$ & $08: 17$ & 51.45 & $20: 47$ & 55.9 & 53.7 & 52.0 \\
\hline $10 / 10 / 98$ & 09:47 & 51.72 & $00: 17$ & 54.5 & 52.9 & 53.0 \\
\hline $10 / 11 / 98$ & $07: 17$ & 48.1 & $00: 17$ & 52.0 & 49.8 & 51.0 \\
\hline $10 / 12 / 98$ & $08: 47$ & 49.21 & $23: 47$ & 52.8 & 51.0 & 50.0 \\
\hline $10 / 13 / 98$ & 09:47 & 51.72 & $21: 17$ & 55.4 & 53.1 & 52.0 \\
\hline $10 / 14 / 98$ & $23: 47$ & 51.72 & $00: 17$ & 54.8 & 53.0 & 53.0 \\
\hline $10 / 15 / 98$ & $07: 47$ & 48.93 & $00: 17$ & 51.5 & 50.1 & 51.0 \\
\hline
\end{tabular}


Summary of Daily Temperature Values and Flows for the Continuous Instream Monitor at Lower Yellowhawk Creek, 1998.

\begin{tabular}{lrrrrrrl}
\hline Date & $\begin{array}{r}\text { Min } \\
\text { Time }\end{array}$ & $\begin{array}{r}\text { Min } \\
\text { Temp (F) }\end{array}$ & $\begin{array}{r}\text { Max } \\
\text { Time }\end{array}$ & $\begin{array}{r}\text { Max } \\
\text { Temp (F) }\end{array}$ & $\begin{array}{r}\text { Daily } \\
\text { Mean }\end{array}$ & $\begin{array}{c}\text { Daily } \\
\text { Mode }\end{array}$ Notes \\
\hline $10 / 16 / 98$ & $08: 17$ & 46.71 & $18: 47$ & 50.9 & 49.0 & 47.0 & \\
$10 / 17 / 98$ & $07: 47$ & 46.16 & $23: 47$ & 51.5 & 48.5 & 47.0 & \\
$10 / 18 / 98$ & $09: 47$ & 48.93 & $19: 17$ & 51.7 & 50.5 & 51.0 & \\
$10 / 19 / 98$ & $10: 17$ & 45.33 & $00: 17$ & 49.5 & 47.4 & 49.0 & \\
$10 / 20 / 98$ & $08: 47$ & 43.93 & $20: 17$ & 48.7 & 46.3 & 44.0 & \\
$10 / 21 / 98$ & $07: 17$ & 44.21 & $19: 47$ & 48.9 & 46.4 & 45.0 & \\
$10 / 22 / 98$ & $09: 47$ & 45.05 & $19: 17$ & 49.8 & 47.2 & 45.0 & \\
$10 / 23 / 98$ & $08: 17$ & 46.44 & $19: 17$ & 51.2 & 48.8 & 51.0 & \\
$10 / 24 / 98$ & $09: 17$ & 46.71 & $00: 17$ & 49.8 & 48.2 & 49.0 & \\
$10 / 25 / 98$ & $08: 17$ & 48.38 & $20: 47$ & 52.3 & 50.3 & 49.0 & \\
$10 / 26 / 98$ & $09: 17$ & 48.1 & $18: 47$ & 52.0 & 50.2 & 52.0 & \\
$10 / 27 / 98$ & $08: 17$ & 47.55 & $19: 47$ & 50.9 & 49.3 & 48.0 & \\
$10 / 28 / 98$ & $08: 47$ & 47.82 & $00: 17$ & 49.5 & 48.5 & 48.0 & monitor removed 12:47 hrs \\
\hline
\end{tabular}

